UNIVERSIDADE DE SÃO PAULO

FACULDADE DE ECONOMIA, ADMINISTRAÇÃO E CONTABILIDADE DEPARTAMENTO DE CONTABILIDADE E ATUÁRIA PROGRAMA DE PÓS-GRADUAÇÃo EM CIÊNCIAS CONTÁBEIS

\title{
AUDIT EXPECTATION GAP NOS LITÍGIOS DAS FIRMAS DE AUDITORIA
}

Gisele Sterzeck

Orientador: Prof. Dr. Luiz Nelson Guedes de Carvalho 
Prof. Dr. Marco Antônio Zago

Reitor da Universidade de São Paulo

Prof. Dr. Adalberto Américo Fischman

Diretor da Faculdade de Economia, Administração e Contabilidade

Prof. Dr. Ariovaldo dos Santos

Chefe do Departamento de Contabilidade e Atuária

Prof. Dr. Luiz Paulo Lopes Fávero

Coordenador do Programa de Pós-Graduação em Controladoria e Contabilidade 


\section{GISELE STERZECK}

\section{AUDIT EXPECTATION GAP NOS LITÍGIOS DAS FIRMAS DE AUDITORIA}

Tese apresentada ao Programa de PósGraduação em Controladoria e Contabilidade do Departamento de Contabilidade da Faculdade de Economia, Administração e Contabilidade da Universidade de São Paulo como requisito parcial para a obtenção do título de Doutor em Ciências.

Orientador: Prof. Dr. Luiz Nelson Guedes de Carvalho

Versão Corrigida

(versão original disponível na Biblioteca da Faculdade de Economia, Administração e Contabilidade)

\section{SÃO PAULO}

2017 
FICHA CATALOGRÁFICA

Elaborada pela Seção de Processamento Técnico do SBD/FEA/USP

\section{Sterzeck, Gisele}

Audit expectation gap nos litígios das firmas de auditoria / Gisele Sterzeck. - São Paulo, 2017.

200 p.

Tese(Doutorado) - Universidade de São Paulo, 2017.

Orientador: Luiz Nelson Guedes de Carvalho.

1. Auditoria 2. Audit expectation gap 3. Responsabilidade do auditor 4. Nvivo I. Universidade de São Paulo. Faculdade de Economia, Administração e Contabilidade. II. Título.

$$
\text { CDD }-647.45
$$


À minha família. 

A Deus por permitir a concretização deste sonho. Aos meus pais, Dirce e Moacir, pelo direcionamento, e ao meu irmão Gustavo, pelo exemplo. À minha família por compreenderem minha ausência.

Ao Prof. Dr. Luiz Nelson Guedes de Carvalho, pelo auxílio em todo o processo. Obrigada por compartilhar seus conhecimentos, por orientar e por fazer com que esse trabalho fosse possível.

Ao meu querido Prof. Dr. Iran Siqueira pela oportunidade e pelo incentivo. Por ser um exemplo de pessoa e de profissional. O mundo precisa de mais pessoas como você.

Ao Prof. Dr. Guillermo Braunbeck pela competência, confiança e disponibilidade. Obrigada pelos conselhos e valiosas conversas.

Aos professores do curso de Doutorado do Programa de Pós-Graduação em Controladoria e Contabilidade com os quais tive a oportunidade e o privilégio de aprender nesse período, mais especificamente: Prof. Dr. Ariovaldo dos Santos, Prof. Dr. Eliseu Martins, Prof. Dr. Alexsandro Broedel, Prof. Dr. Gerlando Augusto Sampaio, Profa. Dra. Silvia Casa Nova e Prof. Dr. Luiz Fávero.

Em especial gostaria de agradecer a Profa. Dra. Elionor Weffort, pelas valiosas discussões e pelo exemplo de profissional

Aos meus queridos amigos Camila Boscov, Patrícia Alves e Rodolfo Chagas pelo incentivo e amizade. Muito obrigada. Aos meus colegas de Mestrado e Doutorado, especialmente Eduardo Flores e Tamya Rebelo, pelas discussões que contribuíram muito para meu trabalho, e aos funcionários da FEA USP.

Aos queridos profissionais da PwC: Tadeu Cendón, Paulo Miron e Renato Barbosa por acreditarem em mim e por serem responsáveis por parte do meu aprimoramento profissional. Muito obrigada pelas inúmeras conversas. Admiro muito vocês. Ao Sr. Arthur Santos, pela paciência, conhecimento e disponibilidade sempre que precisei. Aos amigos e colegas que fizeram a diferença nos meus dias: Rodrigo Bortolazzo, Tulio Lopez, Alessandra Guimarães e Adriano Silva. Obrigada pelo apoio.

Em especial, ao Eduardo, pelas inúmeras contribuições durante essa jornada, pelas discussões sobre Contabilidade e Direito, por seu amor, companheirismo, amizade, paciência e carinho. Obrigada. 

"Por vezes sentimos que aquilo que fazemos não é senão uma gota de água no mar. Mas o mar seria menor se lhe faltasse uma gota". 



\section{RESUMO}

As responsabilidades que envolvem a atividade do auditor é um assunto muito debatido, principalmente em episódios de fraudes e outros escândalos financeiros. Em geral, são nesses momentos que a função do auditor é questionada, e o mercado atribui determinadas responsabilidades a esses profissionais que podem não corresponder com as suas atribuições (Audit Expectation Gap - AEG). Porter (1990) dividiu o AEG em dois principais componentes: (i) Gap de Desempenho e (ii) Gap de Razoabilidade. O último refere-se à diferença de expectativas sobre as quais os usuários das informações financeiras acham que os auditores devem executar determinada tarefa quando de fato eles não têm a obrigação nem o objetivo de fazê-la. Utilizando o constructo de Porter (1990), este trabalho teve como objetivo identificar a existência do AEG de razoabilidade nas decisões de litígios (acórdãos) nos quais as empresas de auditoria figuram como polo passivo. A intenção foi verificar se existem indícios de AEG de razoabilidade com relação às responsabilidades do auditor nos documentos de conclusão dos processos cíveis e administrativos. Para tanto, foram analisados: 11 acórdãos de processos cíveis, 19 acórdãos de processos administrativos CVM e 4 acórdãos de processos administrativos Bacen, totalizando 34 acórdãos. A metodologia empregada foi a análise documental e análise de conteúdo. Para auxiliar na organização e análise dos dados, foi utilizado o software Nvivo®. Além da análise dos acórdãos, foram realizadas entrevistas com exmembros do Colegiado da CVM, para confirmar o entendimento de como funcionam os processos de julgamento nesse Regulador, bem como obter a perspectiva desses profissionais diretamente envolvidos em julgamentos dessa espécie. Para o total dos acórdãos analisados, foi identificada a presença de AEG de razoabilidade em 10 casos, o que representa aproximadamente $29 \%$ do total. Além da identificação AEG de razoabilidade nas argumentações dos juízes, o gap também foi identificado, de forma muito mais frequente, em diversos trechos dos documentos analisados, como, por exemplo, as argumentações da acusação e advogados envolvidos. Os achados desta pesquisa foram importantes pois a identificação da existência desse gap pôde auxiliar no endereçamento desta questão. A tomada de decisão com base em argumentos equivocados pode não apenas trazer prejuízos para as firmas de auditoria, mas também para o Sistema Financeiro Nacional e setor financeiro empresarial em geral, bem como ocasionar injustiças. Como uma das formas de endereçamento do problema, nos casos dos processos administrativos, sugere-se que a composição do Colegiado e do CRSFN seja diversificada, ou mesmo que tenha a presença de um especialista para casos de julgamentos específicos, como são os casos dos julgamentos que envolvem o auditor independente.

Palavras-chave: audit expectation gap. responsabilidade do auditor. auditoria. regulação. 


\begin{abstract}
The responsibilities entailed in the work of the auditor are a subject of much debate, chiefly when frauds and other financial scandals occur. Frequently on these occasions the function of the auditor comes into question and the business world attributes certain responsibilities to these professionals that they may not actually have (Audit Expectation Gap - AEG). The author Porter B. A. (1990) separated AEG into two main components: (i) the performance gap, and (ii) the reasonableness gap. The latter refers to the difference between the expectations of users of financial information regarding the specific tasks they believe auditors should perform and the obligations and objectives those auditors actually have. Using the construct of Porter B. A. (1990), this work has the objective of identifying the existence of the reasonableness gap in legal rulings (decisions of appellate courts) in which audit firms were the defendant. The intention was to identify some evidence of the difference in expectations regarding the work of the auditor in the decisions and opinions of the civil and administrative proceedings. In order to do so, an analysis was made of 11 civil appellate court decisions, 19 administrative rulings of the Comissão de Valores Mobiliários - CVM (equivalent to the Securities and Exchange Commission in the USA) and four administrative rulings of Brazilian Central Bank; 34 judgments in all. The methodology employed was document analysis and content analysis. To aid in the organization and analysis of data, Nvivo ${ }^{\circledR}$ software was used. In addition to analysis of the judgments, interviews were conducted with former members of the CVM board to confirm the understanding of how trial procedures function at this regulator, as well as to gain the perspective of these experts, who are directly involved in judgments of this kind. From the total of the judgments analyzed, the presence of reasonableness $A E G$ was identified in 10 cases, which represents approximately $29 \%$ of the total. In addition to identifying reasonableness $A E G$ in the arguments of judges, this gap was also identified, and much more frequently, in various passages of the documentation on the argumentation of attorneys involved in the cases. The findings of this study are important because identifying the existence of this gap may aid in addressing the issue. Rulings based on misguided arguments can not only harm audit firms but also damage the National Financial System and the corporate financial sector in general, as well as causing injustice. As one way of addressing the issue, in administrative cases it is suggested that the composition of the panel and the CRSFN (Council of Appeals of the National Finance System) be made more diverse, and in certain cases even include a specialist, such as when judgments involve an independent auditor.
\end{abstract}

Key words: audit expectation gap. auditor's responsabilities. audit. NVivo. 


\section{SUMÁRIO}

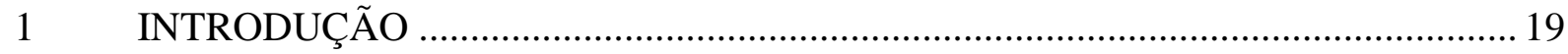

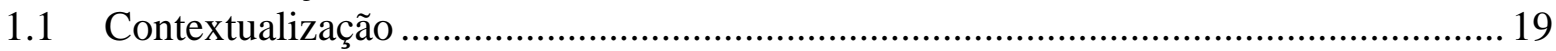

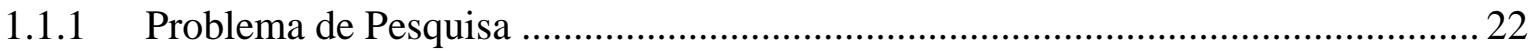

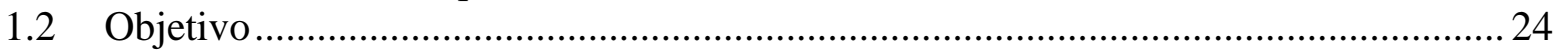

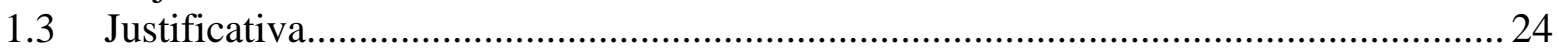

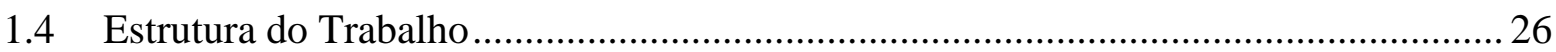

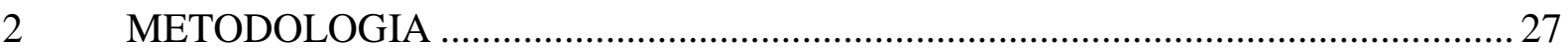

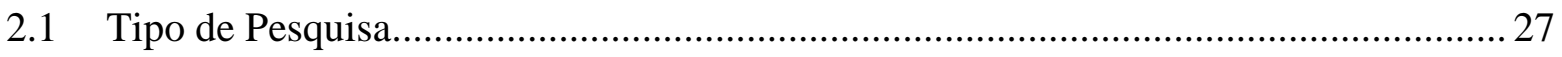

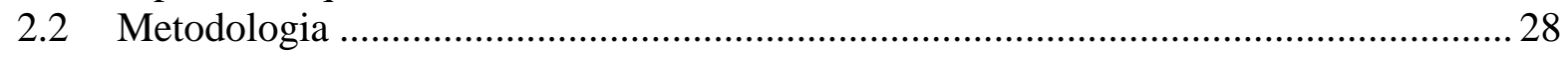

2.2.1 Análise de Conteúdo ............................................................................... 31

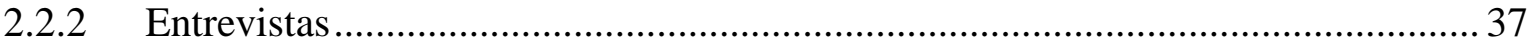

2.3 Considerações sobre os trâmites processuais cíveis..................................................... 40

2.4 Considerações sobre os trâmites processuais administrativos ...................................... 44

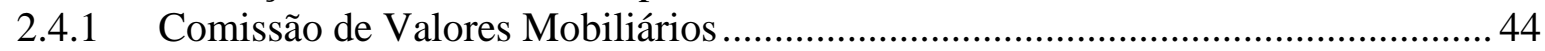

2.4.2 Banco Central do Brasil ...................................................................................... 48

2.5 Coleta e Seleção dos Processos Judiciais e Administrativos .......................................51

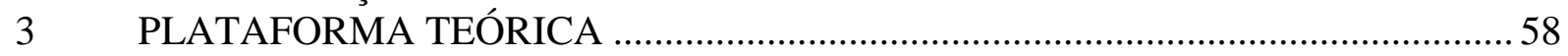

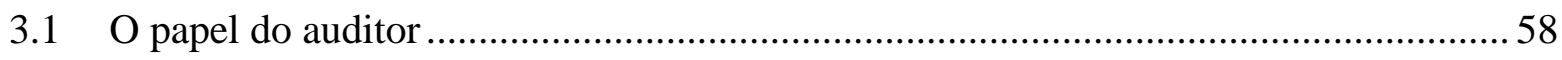

3.2 Objetivos do auditor e as normas de auditoria no Brasil...............................................6 60

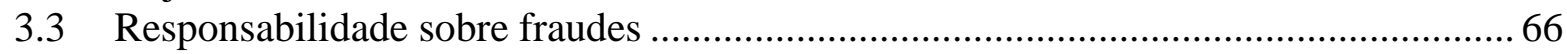

3.4 As firmas de auditoria no Brasil......................................................................... 71

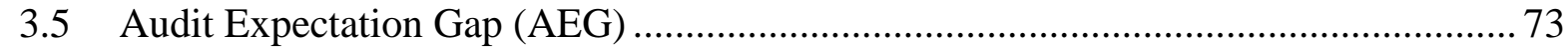

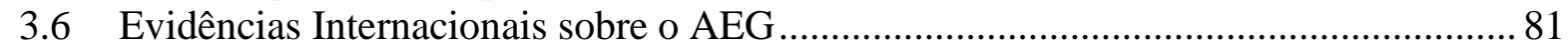

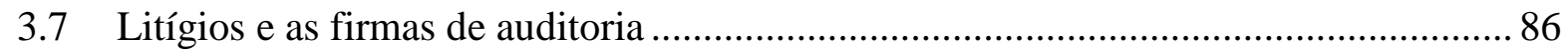

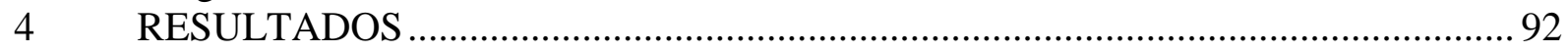

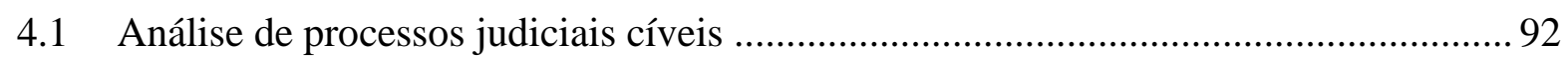

4.1.1 Banco BVA ........................................................................................ 92

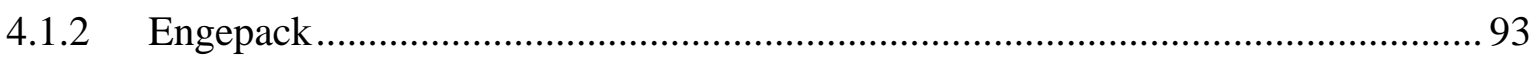

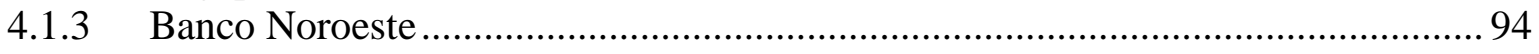

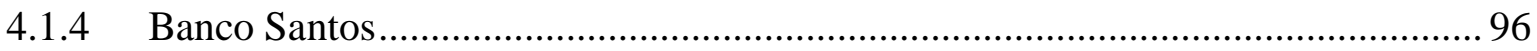

4.1.5 Sociedade Hebraico Brasileira Renascença ………………………………………..... 97

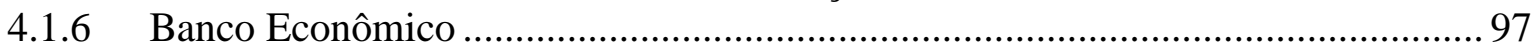

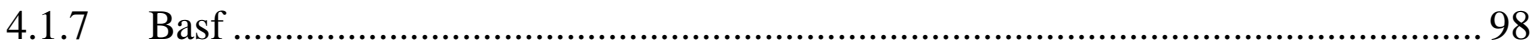

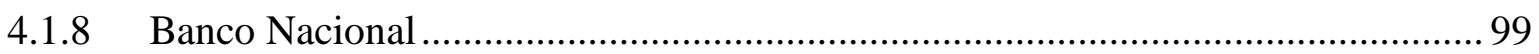

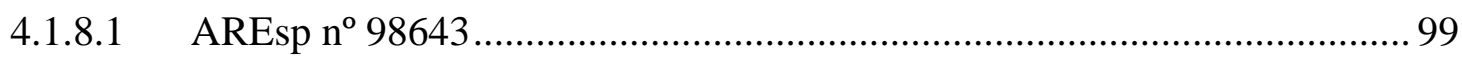

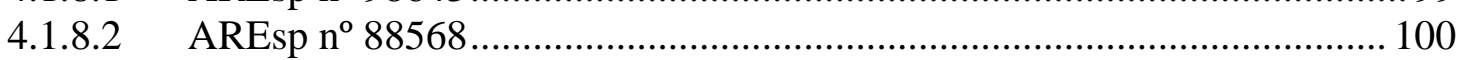

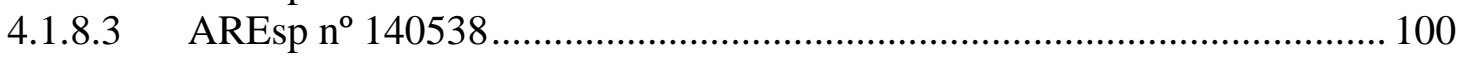

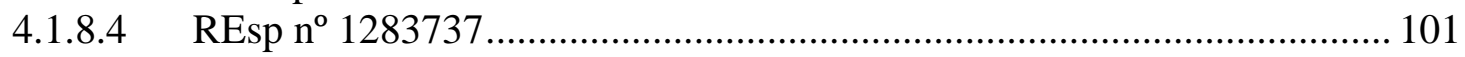

4.2 Análise de processos administrativos - CVM....................................................... 102

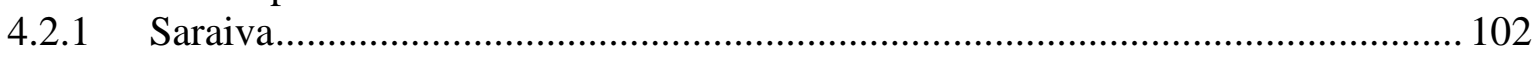

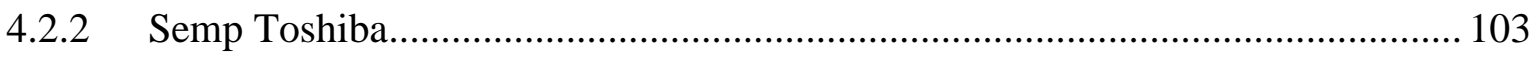

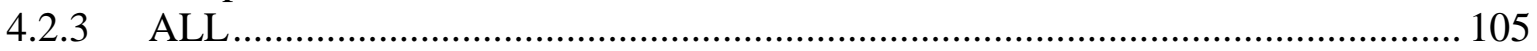

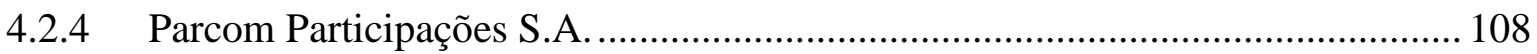

4.2.5 Ribeirão Preto Water Park S.A. …………………………………………........ 109

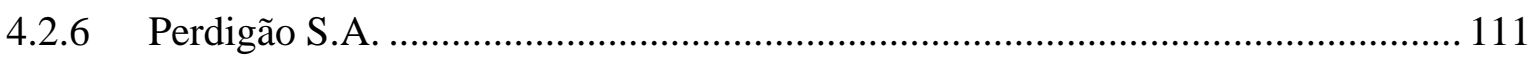

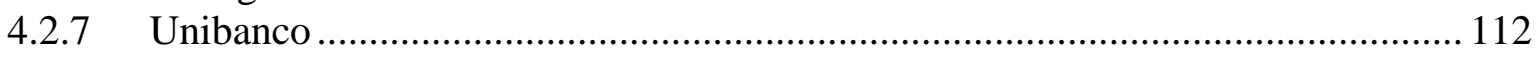

4.2.8 Barreto de Araújo Produtos de Cacau S.A. (BAP) ............................................... 113

4.2.9 Bebidas Antarctica Polar SA ........................................................................... 115 
4.2.10 Union National Fundo de Investimento em Direitos Creditórios ..................... 116

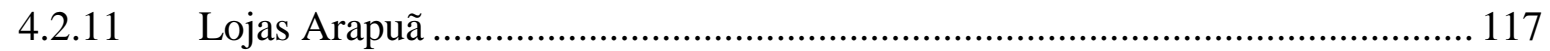

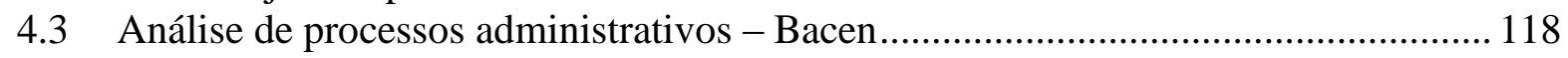

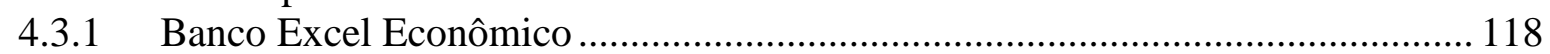

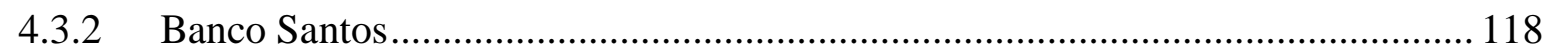

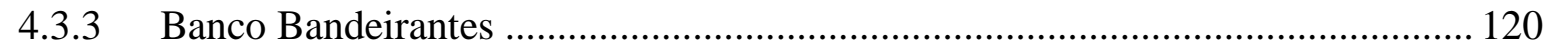

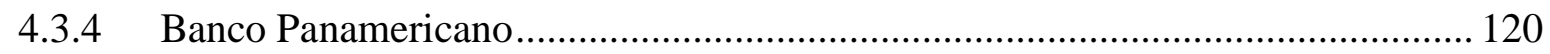

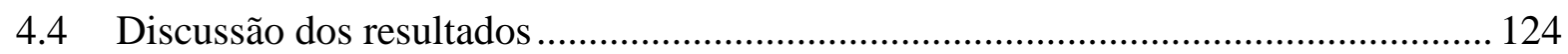

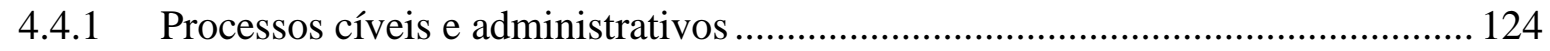

4.4.2 AEG de razoabilidade - Discussão e endereçamento ........................................ 135

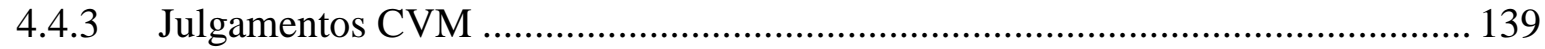

4.4.3.1 O processo de julgamento no Colegiado ............................................... 139

4.4.3.2 Composição do Colegiado .................................................................. 142

4.4.4 Limitações da pesquisa e sugestões de futuras pesquisas ................................... 146

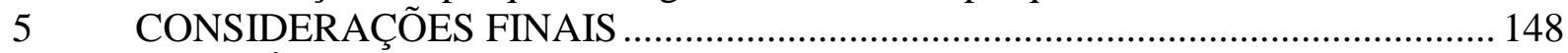

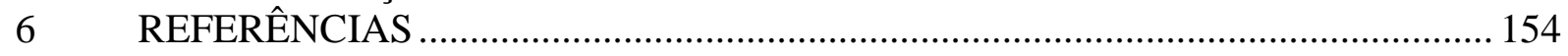




\section{LISTA DE TABELAS}

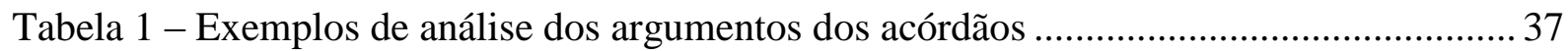

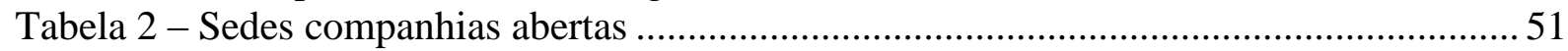

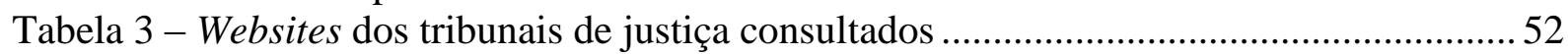

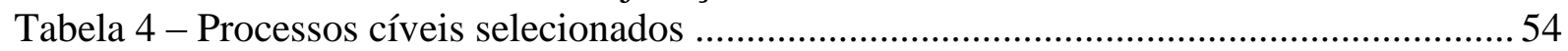

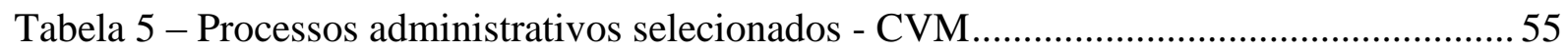

Tabela 6 - Processos administrativos selecionados - Bacen .................................................. 55

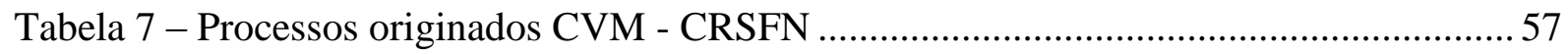

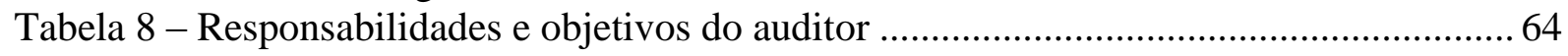

Tabela 9 - Diferenças entre auditoria, investigação de fraude e auditoria forense .................. 70

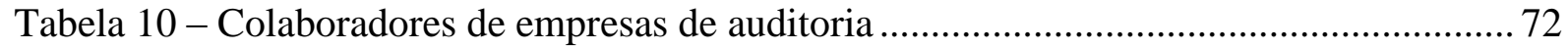

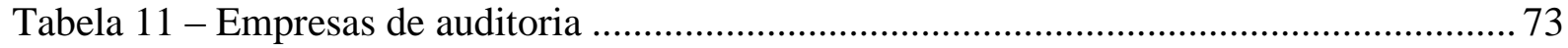

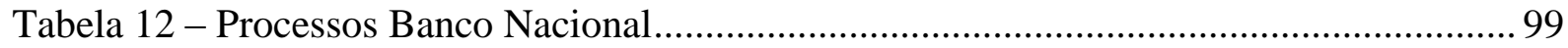

Tabela 13 - Acórdãos de processos cíveis - análises .......................................................... 129

Tabela 14 - Acórdãos de processos administrativos - CVM - análises................................. 130

Tabela 15 - Acórdãos de processos administrativos - Bacen - análises................................ 133 


\section{LISTA DE FIGURAS}

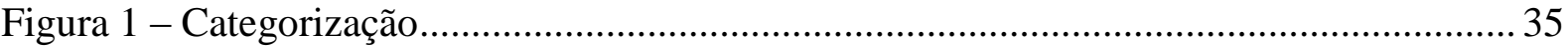

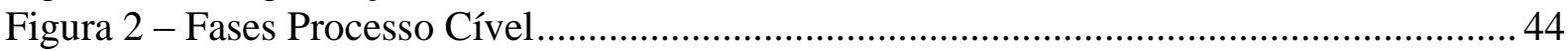

Figura 3 - Fases Processo Administrativo Sancionador - CVM .......................................... 47

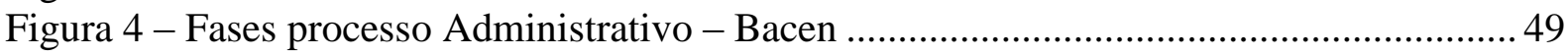

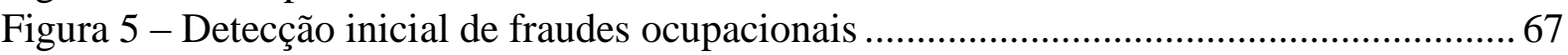

Figura 6 - Estrutura do audit expectation-performance gap ................................................. 78

Figura 7 - Menções à fraude - responsabilidade do auditor ............................................. 125

Figura 8 - Menções à continuidade - responsabilidade do auditor ..................................... 126

Figura 9 - Comparação de menções à Fraude e à Continuidade ........................................... 127

Figura 10 - Menções à não divulgação de fatos relevantes - responsabilidade do auditor ... 127

Figura 11 - Menções a outros temas técnicos - responsabilidade do auditor....................... 128

Figura 12 - Assuntos em processos cíveis (valores percentuais) ...................................... 130

Figura 13 - Assuntos processos CVM (valores percentuais) ............................................ 132

Figura 14 - Assuntos objeto dos processos Bacen (valores percentuais) ............................. 134 


\section{LISTA DE ABREVIATURAS E SIGLAS}

ACFE: Association of Certified Fraud Examiners

Bacen: Banco Central do Brasil

BIG4: Quatro maiores empresas internacionais de auditoria independente

CFC: Conselho Federal de Contabilidade

CRC: Conselho Regional de Contabilidade

CMN: Conselho Monetário Nacional

CNSP: Conselho Nacional de Seguros Privados

CRSFN: Conselho de Recursos do Sistema Financeiro Nacional

CPC: Comitê de Pronunciamentos Contábeis

CPC: Código de Processo Civil

CPA: Certified Public Accountant

CVM: Comissão de Valores Mobiliários

E\&Y: Ernst \& Young Auditores Independentes

DTT: Deloitte Touche Tohmatsu Auditores Independentes

IASB: International Accounting Standards Board

IAASB: International Auditing and Assurance Standards Board

ISA: International Standards on Auditing

IFAC: International Federation of Accountants

Ibracon: Instituto dos Auditores Independentes do Brasil

IFRS: International Financial Reporting Standards

KPMG: KPMG Auditores Independentes

NBC: Normas Brasileiras de Contabilidade

NBC PA: Normas Brasileiras de Contabilidade - Do Auditor Independente

NBC TA: Normas Brasileiras de Contabilidade - Técnicas de Auditoria Independente

NBC TO: Normas Brasileiras de Contabilidade - Asserguração Contábil

PAS: Processo Administrativo Sancionador

PwC: PriceWaterhouseCoopers Auditores Independentes

SEC: Securities Exchange Commission

SFN: Sistema Financeiro Nacional

STF: Supremo Tribunal Federal

STJ: Superior Tribunal de Justiça

Susep: Superintendência de Seguros Privados

TJDFT: Tribunal de Justiça do Distrito Federal

TJSP: Tribunal de Justiça do Estado de São Paulo

TRF: Tribunal Regional Federal 



\section{INTRODUÇÃO}

\subsection{Contextualização}

A atividade de auditoria, atrelada a fatores negativos que normalmente envolvem aspectos financeiros e de governança corporativa relacionados às empresas auditadas, tem sido objeto de críticas e questionamentos e, por vezes, tem culminado em processos judiciais, trazendo à tona discussões sobre o desempenho dos auditores.

Esses fatores negativos podem culminar em situações extremas, como os casos de escândalos contábeis e de fraudes, o que chama a atenção do público e mobiliza o mercado financeiro sobre esses problemas.

Nesses casos, as polêmicas não se restringem apenas aos problemas relacionados à fraude ou à má gestão das empresas, mas envolvem também questionamentos acerca do trabalho do auditor, abrangendo, principalmente, desempenho, funções e responsabilidades.

Em situações como essas, os mais diversos interesses dos stakeholders ficam evidentes: os credores querem saber se vão receber, os acionistas preocupam-se com o tamanho das perdas ou os dividendos não recebidos, reguladores com as consequências e impactos para o mercado de capitais, entre outros. O questionamento geral é a identificação dos responsáveis pelo problema, e o foco se volta para os mecanismos de governança da companhia e também sobre o papel do auditor.

É possível observar uma divergência de expectativas com relação ao papel do auditor, por parte dos usuários das informações financeiras de uma forma geral e as responsabilidades do auditor estabelecidas pelas normas de auditoria. Caracteriza-se, assim, o que a academia considera como um dos tipos de Audit Expectation Gap (AEG).

A diferença de expectativas constitui uma questão importante, pois não está relacionada apenas ao impacto direto que essa questão pode trazer para os profissionais de auditoria independente, mas também os relevantes danos na confiança da profissão contábil.

O auditor emite uma opinião sobre o conjunto das demonstrações financeiras. Essas contêm informações que servem como base para previsões da companhia, e isso vai determinar a alocação de recursos no mercado financeiro de forma geral. A partir do momento que as 
previsões se materializam no presente e algo relevante não foi devidamente previsto, haverá ganhadores e perdedores. Sem dúvida, as pessoas prejudicadas com essa falta ou erro de predição procurarão pelos culpados na tentativa de minimizar suas perdas. Os litígios, por exemplo, são uma das consequências dessa situação. Litígios, conflitos e instabilidade são fenômenos que produzem ineficiências, custos para o sistema financeiro e para o mercado.

De acordo com Porter (1990), as críticas e os processos judiciais são prejudiciais não apenas para os auditores envolvidos nesses processos, mas também porque há a má publicidade associada a esses fatos, que serve para minar a confiança e o respeito do público com o trabalho desses profissionais. Isso levanta sérias preocupações para os auditores, além disso, traz consigo a preocupação de que a futura estabilidade dos mercados financeiros pode estar em risco.

O AEG pode ser considerado um fenômeno global, uma vez que sua existência está documentada em diversas partes do mundo.

A expectativa dos usuários pode ser explicada como o desejo de que o auditor desempenhe determinado trabalho, ou função, no contexto da auditoria das demonstrações financeiras. Essas expectativas tornam-se mais iminentes em contextos de escândalos financeiros e contábeis. Os questionamentos acabam surgindo em discussões relacionadas à comunicação dos auditores sobre problemas da continuidade operacional ou mesmo de questões que envolvam fraude.

A relevância do tema é notória quando evidenciada constantemente por veículos de informações que denotam a existência de determinada expectativa com relação ao trabalho do auditor e, muitas vezes, essa expectativa não está em consonância com as normas de auditoria. Como exemplo, seguem trechos extraídos de reportagem publicada na revista Consultor jurídico (Cristo, 2013):

Para os desembargadores da $14^{\mathrm{a}}$ Câmara de Direito Privado do Tribunal de Justiça de São Paulo, que analisaram o caso, a consultoria tem responsabilidade pela fraude por não tê-la identificado e comunicado aos administradores, trabalho que só uma auditoria poderia fazer.

Segue, também, um trecho do pronunciamento do advogado da empresa da auditoria citada:

Bermudes levará à corte superior o argumento de que a função do auditor se limita a conferir cálculos, e não à veracidade dos lançamentos. 'O auditor não é físcal ou policial. A intenção dos ex-controladores é justificar o próprio erro ao Santander culpando a consultoria'. O advogado acrescenta que a análise que o Banco Central faz é de fatos, diferente da que faz uma auditoria.

A seguir, mostram-se, também, exemplos relacionados à responsabilidade dos auditores em casos de problemas de continuidade operacional das empresas (Agência Estado, 2002): 
O Ministério Público alegava na ação que a auditoria aprovou as contas do Econômico em 28 de julho de 1995, 'omitindo informação que estava obrigada a divulgar, prestando informação incompleta, falsa e tendenciosa'.

A Ernst \& Young respondeu que, de acordo com as normas brasileiras de contabilidade, 'o parecer dos auditores independentes não representa garantia de viabilidade futura da entidade ou algum tipo de atestado de eficácia da administração na gestão dos negócios’.

Percebe-se nos trechos citados que o papel do auditor foi alvo de discussão por advogados, Ministério Público, jornalistas, além das partes envolvidas nesses processos.

De maneira geral, existe o anseio de que os auditores, de certa forma, advirtam os acionistas, credores e pessoas interessadas nas companhias, caso a empresa esteja diante de situações de dificuldades financeiras, independentemente de sua origem, em especial no que tange a questões mais críticas que possam conduzir a problemas de continuidade operacional.

Um dos trabalhos empíricos mais relevantes para a definição do AEG é o de Porter (1990). A proposta da autora é a divisão do AEG em dois componentes: (i) Gap de Desempenho e (ii) Gap de Razoabilidade. O primeiro é composto pelo gap de desempenho dos próprios auditores e pelo gap de padrões deficientes. O gap de razoabilidade trata de diferenças de expectativas sobre as funções e responsabilidades do auditor. O gap de desempenho refere-se à diferença de expectativa com relação ao desempenho do auditor.

Diversos outros trabalhos internacionais identificaram o AEG e discutiram os principais impactos para a auditoria (Best, Buckby, \& Tan, 2001), (De Martini, Aw, \& Kim, 2000), (Dixon, Woodhead, \& Sohliman, 2006), (Epstein \& Geiger, 1994), (Fadzly \& Ahmed, 2004), (Haniffa \& Hudaid, 2007), (Leung \& Chau, 2001), (Porter, 1990). No entanto, percebe-se que os trabalhos não tiveram por objetivo avaliar os potenciais impactos para as firmas de auditoria, e a preocupação maior estava voltada para a identificação do fenômeno.

Há a percepção da existência do problema, principalmente por parte dos reguladores e da classe contábil, pois algumas tentativas do auditor foram sendo tomadas no sentido de evitar discussões e custos decorrentes desse problema. Pode-se tomar como exemplo o aprimoramento das políticas de aceitação de cliente e suas consequências nas avaliações de risco de forma geral; as constantes discussões sobre melhorias nas normas de auditoria e as delimitações das responsabilidades do auditor contidas nessas normas; o aprimoramento da abordagem de controles internos e a melhoria da comunicação do auditor com os usuários do seu produto, por meio da revisão do texto do relatório do auditor. 
Cumpre destacar que o último item aparece constantemente em debates sobre o auditor independente. Uma das ações tomadas na tentativa de reduzir essa diferença de expectativas foi implementar o modelo do relatório do auditor, utilizado atualmente, no qual se especifica à responsabilidade da administração da companhia auditada sobre a elaboração das demonstrações financeiras e à responsabilidade do auditor de expressar uma opinião sobre elas. É importante mencionar que o modelo do relatório do auditor ainda é um tema muito discutido pelos auditores, com o intuito de reduzir esse gap, além de trazer mais informações sobre o trabalho executado pela auditoria.

Embora muito se tenha discutido nos últimos anos sobre o papel do auditor e as formas de reduzir a diferença de anseios em relação ao trabalho da auditoria, trata-se de um tema que constantemente volta à tona. Isso demonstra que esse problema persiste e que pode ser não apenas prejudicial ao mercado, de uma forma geral, pois é de uma falta de entendimento sobre o trabalho de um intermediário informacional, como também pode ser altamente custoso para as firmas de auditoria.

Discussões acerca da identificação do problema e o delineamento de diretrizes, além das mais recorrentes na academia, como as melhorias de educação sobre auditoria e de comunicação dos auditores com o mercado, podem ser de grande valia no entendimento dessa diferença de expectativa e, principalmente, no tocante aos impactos que elas podem gerar.

\subsubsection{Problema de Pesquisa}

Para Kerlinger (1980), um problema de pesquisa é uma questão que mostra uma situação que necessita de discussão, investigação, decisão ou solução. Collins e Hussey (2005) destacam que a maneira clássica, em uma pesquisa acadêmica, é analisar a literatura e identificar lacunas que indiquem áreas originais de pesquisa. No caso deste trabalho, a motivação é a investigação acerca da existência de um problema de entendimento sobre o papel da auditoria independente dentro das empresas.

No Brasil, há a escassez de trabalhos acadêmicos que explorem a auditoria, tanto com relação à parte comportamental do auditor, quanto ao seu papel no contexto dos trabalhos de governança corporativa. Mais escassa ainda é a produção científica de cunho exploratório e explicativo que tenha como enfoque as firmas de auditoria. De acordo com Braunbeck e Carvalho (2012, p. 326): 
De uma forma geral, a produção científica brasileira na temática da auditoria é bastante modesta. Consistentemente com uma área do conhecimento nova dentro da pesquisa acadêmica, a pesquisa apresenta razoável concentração em trabalhos de caráter mais descritivo ou analítico, quando não de caráter normativo ou de verificação de aderência às normas.

O contexto atual do mercado financeiro e de capitais tem necessidade por mais trabalhos com essa temática, até como uma forma de melhorar o entendimento do papel da classe profissional, principalmente em situações de crise, quando são constantemente veiculadas notícias sobre fraude e corrupção.

O principal constructo sobre a definição e delimitações do AEG vem do trabalho de Porter (1990). A autora delimitou o AEG em dois grupos: (i) gap de razoabilidade e (ii) gap de desempenho. O gap de desempenho pode ainda ser subdividido em (a) gap de desempenho dos auditores e (b)gap de padrões deficientes.

O presente trabalho pretende analisar as manifestações de juízes nos processos judiciais que envolvem as firmas de auditoria no Brasil a fim de compreender se esses argumentos denotam uma divergência de expectativas com relação ao papel do auditor. A expectativa é a de que esses argumentos estejam em consonância com as diferenças de percepção sobre o papel e o trabalho efetivo do auditor.

Trata-se de um trabalho inovador no sentido de estudar o AEG em uma de suas formas de materialização: o litígio. Isso pode abranger diversas causas ou fatores além de fraudes, assunto esse estudado de forma mais recorrente, como, por exemplo, problemas de continuidade operacional, entre outros fatores. Além disso, a proposta é trabalhar com uma parcela significativa da população de processos cíveis e dos processos administrativos que envolvem as firmas de auditoria, nos quais essas firmas figuram como rés, o que é muito relevante para se concluir sobre essa matéria em âmbito nacional. Importante mencionar que para cumprir com esse objetivo, será necessária a construção de um banco de dados contendo as informações sobre esses processos, também não disponível no âmbito da academia brasileira.

Diante dos argumentos citados, pretende-se, então, responder à seguinte questão de pesquisa: Existem indícios de Audit Expectation Gap de razoabilidade na decisão de litígios contra as firmas de auditoria no Brasil? 


\subsection{Objetivo}

Este trabalho tem como objetivo geral identificar a existência de AEG de razoabilidade nas decisões de processos judiciais cíveis e administrativos, no Brasil, nos quais os auditores independentes figuram como polo passivo.

É importante mencionar que o trabalho não tem como objetivo relacionar a existência do AEG de razoabilidade com as decisões dos processos analisados.

Para o propósito desse trabalho, a definição de AEG de razoabilidade será a definição proposta por Porter (1990).

Além desse objetivo, outros serão adicionalmente abordados, tais como:

- discussão acerca do entendimento do papel do auditor na visão de agentes do mercado, juízes, reguladores e dos próprios auditores; e

- entendimento e discussão do funcionamento do processo de julgamento na CVM, especificamente por meio de entrevistas, uma vez que este regulador que tem importante atuação fiscalizadora.

- mapeamento dos principais motivos pelos quais os auditores independentes são processados.

- desenvolvimento de um protocolo para a obtenção e análise dos acórdãos e eventualmente outros documentos analisados anexos ao processo.

- identificação de outros tipos de AEG, como o de desempenho e o de padrões deficientes, durante a análise do AEG de razoabilidade.

\subsection{Justificativa}

Este estudo pretende trazer, para a área da contabilidade, contribuições relacionadas à atividade de auditoria no Brasil, além de explorar o entendimento sobre a existência da diferença de expectativas com relação ao "produto" ou relatório do auditor e os seus usuários. 
Pouco se tem feito no Brasil sobre pesquisas relacionadas ao auditor. Trata-se de uma atividade que absorve uma grande quantidade de profissionais da contabilidade e constata-se essa lacuna de pesquisas acadêmicas sobre o tema.

Com relação à produção científica brasileira, alguns dos principais trabalhos procuraram focar nos seguintes aspectos: relação entre gerenciamento de resultado e aspectos da auditoria (Almeida \& Almeida, 2009) e (Martinez, 2010), qualidade da auditoria (Braunbeck, 2010) e (Luccas, 2015), rodízio de auditores (Braunbeck \& Carvalho, 2008), (Assunção \& Carrasco, 2008), (Oliveira \& Santos, 2007) e (Reis, 2009), relatório do auditor (Carvalho, 1989), (Batista, Pereira, Silva, \& Imoniana), (Santos, 2008) e (Luccas, 2015) e aspectos relacionados à história e à evolução da atividade no país (Ricardino \& Carvalho, 2004) e (Silva, 2010).

Considerando a relevância do profissional de auditoria para a classe contábil, a análise da diferença de expectativas com relação ao papel do auditor constitui de uma temática que traz grandes contribuições, pois impacta a segurança jurídica desses profissionais e também evidencia uma discussão sobre seu papel perante os usuários do relatório do auditor e seu papel bem como na sociedade.

No Brasil, os trabalhos de Albuquerque, Dias Filho e Bruni (2010) e Menezes (2012) trouxeram contribuições importantes no tocante à existência do AEG. No entanto, as amostras utilizadas foram de regiões específicas do país e, portanto, há necessidade de estudos mais abrangentes. Adicionalmente, esses estudos tiveram por objeto o papel do auditor com relação à fraude, não abordando, portanto, outras situações que podem gerar diferenças de expectativas, como os casos de problemas de continuidade ou mesmo os de responsabilidade do auditor com relação a informações que são publicadas em conjunto com as demonstrações financeiras.

Além do trabalho de Porter (1990), a literatura internacional apresenta diversos estudos empíricos sobre a existência do AEG em vários países. O foco desses estudos contemplou muitos usuários do trabalho do auditor, como contadores, investidores, estudantes, juízes e os próprios auditores. Um desses atores em especial, os juízes, é de grande interesse para a pesquisa em questão. Entender se existe essa diferença de anseios no papel do auditor é de grande importância, pois os juízes são os responsáveis pela conclusão dos processos judiciais contra os auditores, o que, consequentemente, influencia os passivos legais dessas firmas.

Pesquisadores, como Lowe (1994) e Kimberly, Lowe e Smith (2001), procuraram analisar a diferença de percepções, entre o que os juízes esperam do trabalho do auditor e o que os próprios 
auditores devem fazer de acordo com as normas de auditoria. Os autores concluíram sobre a existência da diferença de percepção nos Estados Unidos. O foco desses estudos foi, portanto, a diferença de percepção desses usuários (os juízes). Mas continua a haver uma carência de pesquisas que comprovem que essa diferença de percepção esteve presente na argumentação de um juiz e influenciou na finalização de um processo, o que possivelmente culminou em um passivo para as firmas de auditoria.

O presente trabalho é inovador, pois tem como proposta avaliar a materialização do AEG, na leitura do sistema jurídico brasileiro e trazer, com isso, discussões sobre o tema também para o judiciário e para o processo de regulação de organismos normatizadores no sistema financeiro nacional, como o caso da CVM e Bacen.

Além disso, outro mérito da pesquisa é a construção de um roteiro para lidar com os documentos sob análise. Devido à dificuldade de obter as informações necessárias, o protocolo e o desenho da pesquisa foram importantes para a viabilização da construção desse conhecimento.

Adicionalmente, vale ressaltar que, geralmente, o foco dos trabalhos de auditoria é o impacto dessas relações sob a ótica das empresas. Este trabalho tem como proposta avaliar os impactos do AEG sob a perspectiva das firmas da auditoria, uma vez que um aspecto, que será analisado sobre esse problema, é sua influência nos litígios das firmas de auditoria.

\subsection{Estrutura do Trabalho}

O trabalho está organizado em cinco capítulos. O primeiro apresenta a introdução, onde está a contextualização da problemática estudada, além das justificativas, objetivo e importância do trabalho.

O segundo capítulo trata da metodologia do trabalho e contempla o tipo de pesquisa, critérios para coleta e seleção da amostra analisada, bem como evidencia os resultados encontrados no trabalho.

O terceiro capítulo trata do arcabouço teórico, no qual é apresentado o conceito do AEG, sua relação com os litígios em firmas de auditoria e as principais contribuições da literatura nacional e internacional sobre o assunto. Além da literatura sobre o AEG, também será feita uma revisão e a contextualização sobre o papel do auditor, seus objetivos e as firmas de auditoria no Brasil. 
O quarto capítulo explora detalhadamente os resultados e análises efetuadas na presente pesquisa.

O último capítulo contém as considerações finais, referências e apêndices.

\section{METODOLOGIA}

\subsection{Tipo de Pesquisa}

O conhecimento, para ser considerado como científico, deve apresentar uma determinada técnica para torná-lo verificável (Gil, 1999, p. 42). Sobre a lógica da pesquisa, Martins e Theóphilo (2007, p. 38), citando Francis Bacon, destacam que o método científico de conteúdo indutivo é um conjunto de regras que estabelece como alcançar generalizações a partir da observação dos fatos. Somente a partir de então, usando os dados obtidos por meio dos sentidos, podem ser buscadas gradualmente cuidadosas generalizações acerca das leis que governam os fenômenos observados.

Para Collins e Hussey (2005, p. 27), “a pesquisa indutiva é um estudo no qual a teoria se forma a partir da observação da realidade empírica; portanto, inferências gerais são induzidas a partir de casos particulares, que é o contrário do método dedutivo". No caso deste trabalho, é justamente por meio da observação da realidade que serão feitas inferências gerais sobre a relação causal entre o AEG e os litígios nas firmas de auditoria.

Sobre o processo da pesquisa, essa pode ser classificada como qualitativa. Para Collins e Hussey, (2005, p. 26), o método qualitativo é mais subjetivo e envolve examinar e refletir as percepções para obter um entendimento de atividades sociais e humanas.

Martins e Theóphilo (2007, p. 136) fazem também algumas contribuições importantes sobre esse tipo de pesquisa, aplicável a este trabalho:

- Os dados coletados são predominantemente descritivos, uma vez que considera, inclusive, a transcrição de relatos.

- Há uma preocupação com o processo e não somente com os resultados, o que torna importante a análise de determinado fenômeno e suas interações com outros elementos.

- Presença de análise indutiva de dados, uma vez que os dados são analisados à medida que são coletados.

- Preocupação com o significado, pois o pesquisador tenta capturar a perspectiva dos envolvidos no estudo, na tentativa de entender melhor o dinamismo entre os elementos que interagem com o objeto da pesquisa.

- Exemplos de tipos de dados qualitativos utilizados nessa configuração de pesquisa são os trechos de documentos, registros, correspondências e transcrições de entrevistas, entre outros. 
Ao considerar o objetivo geral desta pesquisa, ela pode ser caracterizada como exploratória. De acordo com Gil (1999), as pesquisas exploratórias têm como objetivo principal o aprimoramento de ideias ou a descoberta de intuições. Na maioria dos casos, esse tipo de pesquisa envolve: (a) levantamento bibliográfico, (b) entrevistas com pessoas que tiveram experiências práticas com o problema pesquisado e (c) análise de exemplos.

Para Collins e Hussey (2005), na pesquisa exploratória, o pesquisador vai além da descrição das características, analisando e explicando porque ou como os fatos estão acontecendo. Esse tipo de pesquisa tem como objetivo entender fenômenos, descobrindo e mensurando relações causais entre eles.

Trata-se de uma pesquisa exploratória no sentido da intenção de se verificar ou confirmar a ideia de que a existência de diferenças de expectativas, com relação ao trabalho do auditor, pode influenciar as decisões de litígios para as firmas de auditoria.

\subsection{Metodologia}

Para viabilizar esta pesquisa, será utilizada uma estratégia direcionada para a identificação de elementos que relacionem os processos contra as firmas de auditoria e o AEG e será pautada em pesquisa documental e análise de conteúdo. Adicionalmente serão consideradas entrevistas, com profissionais envolvidos no processo de julgamento para complementar o entendimento do objetivo proposto para esta pesquisa.

Sobre a pesquisa documental, Martins e Theóphilo (2007) destacam que sua principal característica é a utilização de documentos como fonte de dados, informações e evidências. Mencionam ainda que os documentos em questão são dos mais variados tipos, como: diários, documentos arquivados em entidades públicas e entidades privadas, gravações, correspondências pessoais e formais, fotografias, mapas etc.

Os autores também mencionam que determinados estudos podem empregar não somente a pesquisa documental, mas também combiná-la com outras estratégias, como entrevistas e observação, que é o caso desta pesquisa.

Bardin (2011, p. 51) menciona que "a análise documental tem por objetivo dar forma conveniente e representar de outro modo essa informação, por intermédio de procedimentos de transformação". 
A diferença entre a pesquisa bibliográfica e a pesquisa documental é que a primeira utiliza fontes secundárias, ou seja, materiais transcritos de publicações disponíveis na forma de livros, jornais, artigos etc. Já a segunda emprega fontes primárias, assim considerados os materiais compilados pelo próprio autor do trabalho, que ainda não foram objeto da análise, ou que ainda podem ser reelaborados de acordo com o propósito da pesquisa (Martins \& Theóphilo, 2007, p. $55)$.

Para este trabalho, a pesquisa documental consiste em analisar as manifestações de juízes por meio dos acórdãos e, quando necessário, outros documentos anexos aos processos, consideradas fontes primárias de informação, nos quais as empresas de auditoria estão envolvidas, como polo passivo, em busca da identificação de elementos que evidenciem a existência do AEG de razoabilidade.

Em complemento à análise documental, será utilizada a técnica de análise de conteúdo.

A análise de conteúdo é um conjunto de técnicas de análise das comunicações, que utiliza procedimentos sistemáticos e objetivos de descrição do conteúdo das mensagens. A técnica tem por intenção a inferência de conhecimentos relativos às condições de produção, essa que recorre a indicadores, quantitativos ou não (Bardin, 2011, p. 44).

$\mathrm{Na}$ análise de conteúdo, a intenção é estudar e analisar a comunicação de maneira objetiva e sistemática. Buscam-se inferências confiáveis de dados e informações com respeito a determinado contexto, por meio de discursos escritos ou orais de seus atores e/ou autores (Martins \& Theóphilo, 2007, p. 95).

As principais características da análise de conteúdo são (Vergara, 2008, p. 16):

Pode ser utilizada, tanto para fins exploratórios, quanto para fins de verificação, confirmando ou não hipóteses ou suposições preestabelecidas.

Exige categorias exaustivas, mutuamente exclusivas, objetivas e pertinentes.

Pode-se trabalhar com uma grande quantidade de dados a serem analisados, no entanto a interpretação desses dados cabe ao pesquisador.

Corre-se o risco, quando se detém nas frequências, de perder-se o que está ausente ou é raro, porém relevante para a análise do objeto em estudo.

É uma técnica que permite a aplicação a diversos tipos de materiais, dentre eles materiais institucionais, discursos e regulamentos. Por se tratar de uma técnica que tem por objeto uma gama de conteúdos que podem ser analisados, trata-se de uma técnica mais adequada para análise dos processos nos quais as firmas de auditoria estão envolvidas. 
Vergara (2008), ao comparar a análise do discurso com a análise de conteúdo, menciona que a primeira investiga como o conteúdo é usado para o alcance de determinados efeitos, enquanto na segunda a intenção é verificar o que se fala.

Martins e Theóphilo (2007) destacam que a aplicação dessa técnica geralmente acontece após, ou em conjunto com uma pesquisa documental, ou mesmo após a realização de entrevistas. Os autores ainda complementam que a análise de conteúdo busca a essência de um texto nos detalhes das informações. Não trabalha somente com o texto de forma objetiva, mas também com detalhes do contexto, não se restringindo, portanto, à descrição dos conteúdos, mas desejando-se inferir sobre o todo da comunicação.

Dentre alguns dos principais usos da análise de conteúdo apontados por Martins e Theóphilo (2007, p. 96), dois em específico vão ao encontro aos objetos deste trabalho:

Auditar conteúdos de comunicações e compará-los com padrões, ou determinados objetivos. Identificar intenções, características e apelos de comunicadores.

Com relação à fonte primária de informações, que, no caso deste trabalho será representada pelos processos judiciais. Conforme, Oliveira e Silva (2005) a classificação para este tipo de análise é a de pesquisa documental. Adicionalmente, por se tratar de documentos históricos e oficiais, o trabalho com esse tipo de documento traz pelo menos duas implicações metodológicas: a questão do poder e a da interpretação.

As autoras ainda complementam que a questão do poder aparece porque o Estado pode ser considerado o verdadeiro produtor do que está escrito, encobrindo a expressão de qualquer grupo social que esteja contida no documento em forma de depoimento, por exemplo, ou mesmo na argumentação do juiz que, além de membro de um dos poderes do Estado, também pode ser visto como membro de uma corporação profissional. E com relação à questão da interpretação, ela surge porque se trabalha com o que está escrito e não com o acontecimento em si, ou ainda porque não se está interpretando por meio de observação direta, mas por meio da palavra escrita, e isso é fonte de inúmeros questionamentos que envolvem a questão da subjetividade.

Um ponto fundamental no trabalho dessas autoras é a menção de que os juízes não são atores neutros, ou mero porta-vozes do discurso oficial do Estado. Seus valores influenciam a sua atuação. É necessário considerar os filtros que a justiça impõe, mas não se deve considerar que 
a narrativa não contenha o modo como a pessoa vivencia sua realidade. O processo contém formulações dos diversos segmentos envolvidos e não apenas do Estado.

A conclusão de um processo judicial, que consubstancia formalmente uma relação de conflito, representa não apenas uma resposta do estado a essa situação, mas também leva em consideração a formação pessoal e profissional de um juiz, na determinação da decisão definitiva do processo.

É importante mencionar a existência dessas considerações quando se analisam processos judiciais. No entanto, esse trabalho não tem por objetivo explorar elementos sociais e da formação dos juízes e como isso influencia na tomada de decisão.

Ainda com relação à utilização de processos judiciais como fonte de pesquisa, Rosemberg e Souza (2009) mencionam que se deve entender cada momento e cada ato contido nos processos, tentando esclarecer, com base na legislação e na jurisprudência, suas particularidades, propósitos e contradições. Tudo isso para que se possa ter uma visão mais ampla possível de pontos de vista e de estratégias envolvidas no embate jurídico e social que subjaz ao processo, de acordo com as ações dos diferentes agentes envolvidos.

Uma das limitações desse tipo de análise deve-se ao fato da transcrição de procedimentos orais para a forma escrita. Nesse caso, há uma redução das possibilidades expressivas verbais às amarras do texto escrito, restringindo o discurso a uma linguagem forense (Rosemberg \& Souza, 2009).

Uma outra crítica, considerada por Rosemberg e Souza (2009), é que os processos judiciais devem ser tomados, primeiro, enquanto mecanismos de construção da verdade, um campo de luta onde se digladiam discursos (versões) que têm como objetivo se impor sobre discursos (versões) adversários.

\subsubsection{Análise de Conteúdo}

A análise de conteúdo organiza-se em torno de três polos cronológicos, segundo Bardin (2011, p. 126):

1) Pré-análise;

2) A exploração do material;

3) O tratamento dos resultados. 
A pré-análise caracteriza-se fundamentalmente pela escolha dos documentos que serão analisados para atenderem aos objetivos da pesquisa em questão.

Os tipos de instrumentos que podem ser analisados são:

○ Agravo de instrumento: trata-se de um recurso interposto, ou seja, uma revisão de uma decisão judicial, normalmente contra decisões intermediárias (interlocutórias). Destinase à impugnação de decisões interlocutórias (Conselho da Justiça Federal, 2001).

○ Acórdão: decisão de um órgão judiciário colegiado, tomada por votos; veredito de um tribunal (Conselho da Justiça Federal, 2001). De acordo com o artigo 204 do Código do Processo Civíl, é o julgamento colegiado proferido pelos tribunais (Lei 13.105, 2015).

- Apelação: trata-se de um recurso interposto contra a sentença de um juiz de primeiro grau, afim de submeter ao grau superior o reexame de todas as questões sucitadas na causa e nos limites do próprio mérito (Conselho da Justiça Federal, 2001).

○ Sentença: ato pelo qual o juiz finaliza o processo, decidindo ou não o mérito da causa. (Conselho da Justiça Federal, 2001). A sentença pode ser de dois tipos: com solução de mérito e sem solução de mérito.

- Petição inicial: é o pedido inicial do processo, a peça processual que instaura o processo jurídico. Nela constam informações como os fatos e fundamentos jurídicos do pedido, valor da causa, informações pessoais dos autores e juiz a que se dirige o autor (Lei 13.105, 2015).

○ Contestação: instrumento por meio do qual o réu impugna o pedido formulado pelo autor de uma ação. Incumbe ao réu alegar, na contestação, toda a matéria de defesa, expondo as razões de fato e de direito com que impugna o pedido do autor e especificando as provas que pretende produzir (Lei 13.105, 2015, art. 336).

Os documentos a serem escolhidos e submetidos à análise serão representados no contexto de processos judiciais pelos acórdãos que contêm a decisão em segunda instância e envolvem mais de um juiz.

O fato de escolher os acórdãos como principais objetos a serem analisados na pesquisa não desconsidera a análise de outros documentos anexos aos processos. A petição inicial, por 
exemplo, pode ser consultada caso se deseje obter um entendimento melhor do processo onde as informações não estejam claras na decisão judicial ou mesmo em situações nas quais o texto do acórdão não apresente elementos suficientes para o propósito desta pesquisa. Além disso, como este estudo não pretende relacionar a existência do AEG de razoabilidade com a decisão do processo em questão, a análise de outros documentos que auxiliem no entendimento do mérito e das discussões da responsabilidade do auditor, complementariam o entendimento dos casos estudados.

A opção pela análise de processos cíveis em segunda instância denota maior viabilidade processual, na medida em que já passou pela primeira instância e está em fase de apelação. Nesse caso já houve uma triagem judicial.

No acórdão, normalmente, constam detalhes sobre a situação sub-judice, bem como a justificativa decorrente de eventual divergência na deliberação em questão.

É importante destacar que esta pesquisa não tem por objetivo relacionar a decisão do processo com a existência de AEG de razoabilidade. Durante a análise dos acórdãos, serão considerados os trechos do documento que discutem sobre a responsabilidade do auditor. Nem sempre esse será o mérito do processo e, consequentemente, a decisão pode não estar diretamente relacionada à responsabilidade do auditor. Haverá casos, por exemplo, em que o auditor é um dos acusados, junto com a administração de alguma companhia, e o mérito do processo não será exclusivamente a atuação do auditor.

Para o propósito desta pesquisa ao se optar pela análise de uma parcela representativa dos processos cíveis e pela população total de processos administrativos, cumpre-se com esses documentos, portanto, as regras para o corpus $^{1}$, proposto por Bardin (2011, p. 126):

Regra de exaustividade: na qual não se pode deixar de fora elementos que não possam ser justificáveis no plano de rigor.

Regra da representatividade: amostra analisada deve ser representativa do universo inicial. Regra da homogeneidade: documentos não devem apresentar demasiada singularidade. Regra da pertinência: os documentos devem ser pertinentes como fonte de informação.

\footnotetext{
${ }^{1}$ Conjunto de documentos tidos em conta para serem submetidos aos procedimentos analíticos da Análise de Conteúdo.
} 
A exploração do material consiste em operações de codificação, essas que correspondem a uma transformação de dados brutos do texto que, por recorte, agregação e enumeração, permite atingir uma representação do conteúdo ou da sua expressão (Bardin, 2011, p. 133).

Para o propósito desta pesquisa, a unidade de registro mais pertinente será o tema. Trata-se de uma afirmação sobre um determinado assunto. O tema é a "unidade de significação que se liberta naturalmente de um texto analisado segundo certos critérios relativos à teoria serve de guia a leitura" (Bardin, 2011, p. 135).

De acordo com Bauer e Gaskell (2015, p. 199) , "embora o corpus de texto esteja aberto a uma multidão de possíveis questões, a Análise de Conteúdo interpreta o texto apenas à luz do referencial de codificação, que constitui uma seleção teórica que incorpora o objetivo da pesquisa".

A intenção do presente trabalho, neste caso, é a recortar as ideias presentes nos acórdãos, com base no tema pré-definido, que é a responsabilidade ou funções do auditor independente e procurar analisar esses recortes, na intenção de verificar as similaridades e diferenças de ideias sobre esse tema em específico. As seguintes identificações, portanto, são úteis para essa pesquisa:

(i) Objeto: responsabilidade do auditor

(ii) Personagem: auditor

(iii) Acontecimento: litígio

(iv) Documento: acórdão

Após a definição da codificação é necessário proceder a categorização. De acordo com Bardin (2011, p. 147), “as categorias são rubricas ou classes, as quais reúnem um grupo de elementos sob um título genérico, agrupamento esse efetuado em razão das características comuns desses elementos".

Para auxiliar no processo de categorização e organização das informações, será utilizado o software NVivo®. De acordo com os desenvolvedores do software, ele fornece um conjunto de ferramentas para suportar a análise qualitativa de dados. Com isso, têm-se um aumento da eficiência das análises. O software permite, portanto: gerenciar dados e ideias, consultar dados 
(querys), processar informações em forma de relatórios pré-definidos (Bazeley \& Jackson, 2013, p. 3).

Antes do início da análise dos processos, foi efetuada uma análise prévia na tentativa de identificação dos principais assuntos que envolviam as responsabilidades do auditor, no contexto dos acórdãos, que permitisse a categorização desses documentos. Com base nessa análise preliminar, então, os seguintes termos dentro do tema de responsabilidade do auditor:

(i) Fraude

(ii) Continuidade

(iii) Outros - Procedimentos

(iv) Outros - Não divulgação de informação relevante

Figura 1 - Categorização

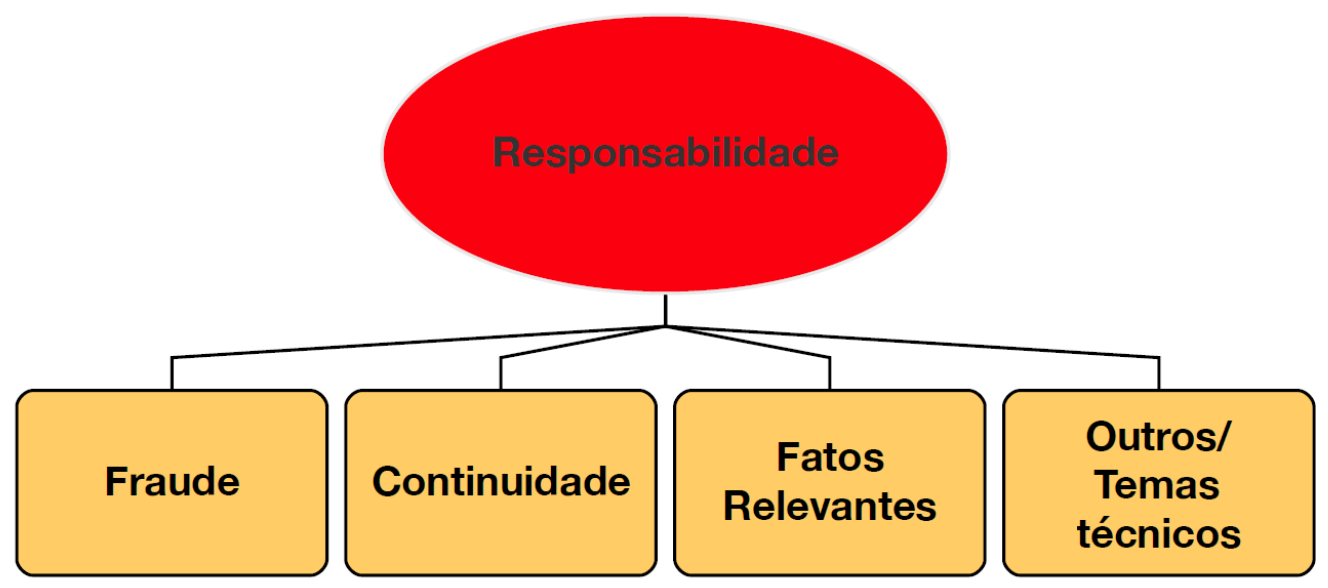

Fonte: Elaborada por esta autora

A definição das categorias está de acordo com os principais exemplos de AEG identificados por (Porter B. A., 1990). Com relação a "Fraude", por exemplo, a autora aponta que detectar menores roubos dos ativos dos clientes das empresas de auditoria, efetuados pelos empregados, é um tipo de AEG de razoabilidade. Outros autores como Alleyne e Howard, (2005), Best, Buckby, e Tan (2001), Dixon, Woodhead, e Sohliman (2006), Fadzly e Ahmed (2004) e Porter, Ó hÓgartaigh, e Baskerville (2012a) também relacionaram o AEG e a fraude. 
No caso das categorias de não divulgação de fatos relevantes ou de outros temas técnicos, elas estão relacionadas com um tipo de gap de razoabilidade aplicado a um assunto específico, como por exemplo garantir a acurácia de determinado número contábil que não tenha sido escopo do trabalho da auditoria. Garantir acurácia das demonstrações financeiras é um tipo de AEG, de acordo com Porter B. A. (1990). No contexto da análise processual, essa questão pode estar relacionada com a falta de divulgação adequada sobre o assunto (categoria Fato Relevante) ou a ausência de procedimentos (categoria Outros/Temas Técnicos).

A expectativa é a de que a maior parte das responsabilidades, dentro desse contexto do trabalho, seja relacionada à Fraude (i) e à Continuidade (ii). Tem-se a expectativa de que as demais categorias que forem identificadas no conteúdo analisado sejam relacionadas ao desempenho do auditor, ou seja, à suficiência de seus procedimentos de auditoria (iii) ou à falta de menção no relatório do auditor de informações relevantes (iv).

Após o trabalho de categorização, será feita a análise dos acórdãos dos processos judiciais em busca de discussões sobre a responsabilidade do auditor. O processo identificação da existência de AEG de razoabilidade consistirá em analisar os argumentos utilizados pelos juízes sobre esse assunto e compará-los com as normas de auditoria e discussões acerca do tema.

Exemplos: 
Tabela 1 - Exemplos de análise dos argumentos dos acórdãos

\begin{tabular}{l}
\hline Argumento do acórdão \\
\hline Os pareceres e balanços patrimoniais \\
emitidos e divulgados por empresas de \\
auditoria e consultoria contábil não podem \\
ser interpretados como garantia de \\
viabilidade da entidade financeira (...) (grifo \\
desta autora) (BRASIL, 2011a, p. 7).
\end{tabular}

Os auditores independentes entendem a função da auditoria como exame atinente à fidedignidade das demonstrações contábeis sob que se debruçam, o que implica a descoberta de fraudes e erros, bem como a prestação de informações acerca dos controles internos da companhia (Grifo desta autora) (Ministério da Fazenda, 2014b).

\section{Norma de Auditoria \\ De acordo com a NBC TA}

260: A administração é

responsável pela elaboração

das demonstrações contábeis,

com a supervisão geral dos

responsáveis pela governança

$\mathrm{e}$, em alguns casos, a

administração é responsável,

também, pela aprovação das

demonstrações contábeis da

entidade (em outros casos, os

responsáveis pela governança

têm essa responsabilidade).

De acordo com a NBC TA

240: A principal

responsabilidade pela

prevenção e detecção da

fraude é dos responsáveis

pela governança da

entidade e da sua

administração. $\mathrm{O}$ auditor

que realiza auditoria de

acordo com as normas de

auditoria é responsável por

obter segurança razoável

de que as demonstrações

contábeis, como um todo, não contém distorções

relevantes, causadas por

fraude ou erro.

É certo que a auditoria zela pela eficiência dos dados contábeis e pela saúde financeira da empresa' (BRASIL, 2013)(Grifo desta autora).
De acordo com a NBC TA

200: A opinião do auditor,

portanto, não assegura, por

exemplo, a viabilidade

futura da entidade nem a

eficiência ou eficácia com

a qual a administração

conduziu os negócios da

entidade.
Existência de gap de

razoabilidade pois a

responsabilidade

primária de

identificação de

fraudes é a

administração.
Existência de gap de razoabilidade, pois o auditor não tem responsabilidade sobre a eficiência da administração ou sobre a saúde financeira da empresa auditada.

\subsubsection{Entrevistas}

Com relação às entrevistas. Entrevista é uma técnica de pesquisa para coleta de informações cujo objetivo é entender o significado que os entrevistados atribuem a situações de interesse ao 
pesquisador. É considerada estruturada quando orientada por um roteiro pré-definido aplicado a todos entrevistados. Já a semiestruturada é também é conduzida com o uso de um roteiro mas com liberdade para serem acrescentadas outras perguntas pelo entrevistador (Martins \& Theóphilo, 2007).

No caso da presente pesquisa, foram consideradas entrevistas semiestruturadas. Os entrevistados selecionados foram profissionais que já tiveram experiência como participantes em julgamentos contra firmas de auditoria. Ao fazer a análise prévia dos acórdãos, verificou-se que os relatórios de decisão da CVM são mais robustos quando comparados aos demais documentos analisados. $\mathrm{O}$ fato de apresentarem mais discussões para o embasamento dos seus votos permite efetuar análises mais ricas do entendimento das responsabilidades do auditor na visão desses profissionais.

Além disso, os acórdãos da CVM são a maioria dos documentos analisados nesta pesquisa. Para tanto, entende-se que para complementar o entendimento obtido por meio da pesquisa documental e por meio da análise de conteúdo, as entrevistas com ex-membros do Colegiado da CVM trariam significativas contribuições para esta pesquisa. Além dessa contribuição, também foram de grande relevância a confirmação do funcionamento das fases dos processos com profissionais que atuaram nessa autarquia.

O convite aos ex-membros do Colegiado foram enviados por email. Os ex-membros do Colegiado para os quais foram enviados os emails com convites para a entrevista foram: Luciana Pires Dias, Luiz Leonardo Cantidiano, Prof. Dr. Eliseu Martins e Pedro Marcílio.

Além dos ex-membros do Colegiado, também foi entrevistado o Prof. Dr. Nelson Carvalho, Professor Sênior na Faculdade de Economia, Administração e Contabilidade na Universidade de São Paulo (FEA/USP), que leciona sobre auditoria, além de ser parecerista em casos envolvendo litígios contábeis com reguladores, controladores, minoritários e auditores.

Anexos foram enviados os seguintes documentos: (i) uma apresentação contendo as principais informações e objetivos o trabalho e (ii) um fluxograma com o entendimento das fases do processo na CVM. Segue o roteiro definido para a pesquisa:

1. Explicação sobre o objetivo da tese.

2. Entendimento do funcionamento dos processos administrativos sancionadores na CV. 


\section{Perguntas:}

I. No caso de recurso por parte do acusado, em julgamentos do Colegiado, quando isso culmina na transferência do caso para a esfera do judiciário? ${ }^{2}$ De forma semelhante, como funciona o recurso de um acusado no caso de insatisfação com uma decisão de um Superintendente de Área Técnica? Tendo em vista as decisões administrativas e judiciais, essas decisões são alternativas e excludentes ou podem ser cumulativas?

II. Historicamente, o Colegiado da CVM é formado com profissionais do direito, com experiências no direito societário ou comercial. Qual a sua opinião sobre o envolvimento de outros profissionais, que não os do direito, no caso dos julgamentos dos Processos Administrativos Sancionadores? ${ }^{3}$

III. Existe alguma participação de membros do Colegiado nos processos administrativos não sancionadores? $?^{4}$

IV. Como funciona a comunicação no caso de processos que envolvem o Banco Central do Brasil? (Tanto no caso de processos originados na CVM e originados no Bacen).

V. Quais oportunidades de melhoria que o Sr./Sra. identificam nesse processo?

As entrevistas foram realizadas com os seguintes profissionais:

(i) Luciana Pires Dias. Entrevista realizada no dia 17/08/2016 via Skype®.

(ii) Luiz Leonardo Cantidiano. Entrevista realizada no dia 07/09/2016 via telefone.

(iii) Prof. Dr. Eliseu Martins. Entrevista realizada no dia 01/09/2016 via Skype®.

(iv) Pedro Marcílio. Entrevista realizada no dia 04/10/2016 via telefone.

(v) Prof. Dr. Nelson Carvalho. Entrevista realizada durante o processo de orientação.

\footnotetext{
${ }^{2}$ Caso de insatisfação com o resultado na esfera administrativa.

${ }^{3}$ Regimento interno da CVM (Portaria 327) menciona que serão nomeados pelo Presidente da República pessoas com reconhecida competência em matéria de mercado de capitais. Atribuições do Colegiado muito relacionada e estabelecimento de normas do $\mathrm{CMN}$, exercer atribuições legais e diversas outras atribuições, não relacionadas apenas com os julgamentos.

${ }^{4}$ Julgado pela Superintendência a que corresponde o mérito do processo.
} 
Todas as entrevistas foram transcritas em documento word por uma empresa especializada e enviados para aprovação dos respectivos entrevistados.

Com relação à autorização das respectivas entrevistas, foram obtidos o Termo de Consentimento Livre e Esclarecido e a autorização sobre a transcrição da entrevista. (Ver Apêndices J e K).

As autorizações para divulgação dos nomes dos entrevistados e conteúdo da entrevista transcrita foram obtidas conforme seguem:

(i) Luciana Pires Dias: email de autorização recebido no dia 28/11/2016.

(ii) Luiz Leonardo Cantidiano: email de autorização recebido no dia 08/12/2016.

(iii) Prof. Dr. Eliseu Martins: email de autorização recebido no dia 12/12/2016.

(iv) Pedro Marcílio: email de autorização recebido no dia 05/12/2016.

(v) Prof. Dr. Nelson Carvalho: autorização recebida durante o processo de orientação.

\subsection{Considerações sobre os trâmites processuais cíveis}

De forma intuitiva, pode-se relacionar um processo judicial como a materialização sobre a falta de entendimento em determinada matéria. Se existe uma parte que considera estar sofrendo um determinado dano por outra parte e ambas não chegam a um entendimento ou a uma solução para o caso, trata-se de um caso que deve ser resolvido pelo sistema jurídico. Um processo, portanto, é o conjunto de atos logicamente concatenados e organizados com vistas à obtenção de um fim, um pronunciamento judicial, ou seja, a sentença.

A antiga versão do CPC $^{5}$ (Lei 5.869, 1973) mencionava que eram aplicáveis a todas as causas os procedimentos comuns. Esses, por sua vez, poderiam ser ordinários ou sumários.

O procedimento ordinário está dividido em quatro fases:

(i) a postulatória, em que o autor apresenta a petição inicial e o réu a sua resposta;

\footnotetext{
${ }^{5}$ Código de Processo Civil
} 
(ii) a ordinatória, em que o juiz saneia o processo e aprecia os requerimentos de provas formulados pelas partes;

(iii) a instrutória, em que são produzidas as provas, como, por exemplo, a pericial ou mesmo uma inspeção judicial e a

(iv) decisória, que terá a sentença.

Essa divisão é feita levando em conta o tipo de ato predominante em cada fase. Na postulatória, prevalecem os requerimentos das partes. Porém, isso não significa que já não sejam produzidas provas (em regras documentais), e que o juiz não profira decisões.

O mesmo ocorre nas outras fases, em que há um tipo de ato predominante, embora não necessariamente único.

De acordo com a Lei 5.869/73, em seu artigo 275, para os casos de procedimentos sumários (Lei 5.869, 1973):

Art. 275. Observar-se-á o procedimento sumário: (Redação dada pela Lei $n^{\circ}$ 9.245, de 26.12.1995)

I - nas causas, cujo valor não exceder 20 (vinte) vezes o maior salário mínimo vigente no País; (Redação dada pela Lei no 5.925 , de $1^{\circ} .10 .1973$ )

I - nas causas cujo valor não exceda a 60 (sessenta) vezes o valor do salário mínimo; (Redação dada pela Lei $\mathrm{n}^{\circ} 10.444$, de 7.5.2002)

II - nas causas, qualquer que seja o valor; (Redação dada pela Lei no 9.245, de 26.12.1995)

a) de arrendamento rural e de parceria agrícola; (Redação dada pela Lei $n^{\circ} 9.245$, de 26.12.1995)

b) de cobrança ao condômino de quaisquer quantias devidas ao condomínio; (Redação dada pela Lei $\mathrm{n}^{\circ}$ 9.245, de 26.12.1995)

c) de ressarcimento por danos em prédio urbano ou rústico; (Redação dada pela Lei n ${ }^{\circ} 9.245$, de 26.12.1995)

d) de ressarcimento por danos causados em acidente de veículo de via terrestre; (Redação dada pela Lei $\mathrm{n}^{\circ}$ 9.245, de 26.12.1995)

e) de cobrança de seguro, relativamente aos danos causados em acidente de veículo, ressalvados os casos de processo de execução; (Redação dada pela Lei nº 9.245, de 26.12.1995)

f) de cobrança de honorários dos profissionais liberais, ressalvado o disposto em legislação especial; (Redação dada pela Lei no 9.245, de 26.12.1995)

g) nos demais casos previstos em lei. (Redação dada pela Lei ${ }^{\circ} 9.245$, de 26.12.1995)

h) que versem sobre revogação de doação; (Redação dada pela Lei no 12.122 , de 2009).

i) nos demais casos previstos em lei. (Incluído pela Lei $n^{\circ} 12.122$, de 2009).

Parágrafo único. Este procedimento não será observado nas ações relativas ao estado e à capacidade das pessoas. (Redação dada pela Lei n 9.245, de 26.12.1995)

A principal diferença entre os procedimentos sumários e ordinários é a de que no primeiro buscava-se praticar um maior número de atos processuais no mesmo ato (maior concentração).

Era possível que um juiz convertesse um procedimento sumário em um procedimento comum ordinário, dependendo da complexidade do caso (Lei 5.869, 1973, Art. 277). 
De acordo com o novo CPC (Lei 13.105, 2015), de março de 2015, deixou de existir o procedimento sumário, permanecendo apenas o procedimento comum ordinário. No entanto é importante mencionar essa distinção para que se tenha o entendimento da evolução processual ao longo do tempo.

O processo se inicia quando o autor envia a inicial ao juiz. Primeiramente, o juiz manifesta-se a respeito da Assistência Judiciária Gratuita $(\mathrm{AJG})^{6}$. Caso indefira o pedido, cabe um recurso para o Tribunal de Justiça chamado Agravo de Instrumento.

Após resolver a existência ou não da AJG, o juiz analisa a questão da antecipação de tutela/liminar, podendo tanto deferir como indeferir o pedido. Caso indefira, cabe recurso Agravo de Instrumento - para o Tribunal de Justiça. Superada a questão, o juiz manda citar a outra parte para contestar a ação.

Assim sendo, a parte contesta a ação, e o juiz manda intimar o autor para apresentar réplica à contestação do réu. Após apresentada a réplica, o juiz intima as partes e lhes dá a oportunidade de requerer outras provas. Se as partes as desejarem, deverão apresentá-las, ou se desejarem provas testemunhais ou depoimento pessoal, será marcada uma audiência.

Realizadas as provas, o juiz intimará as partes para que se manifestem sobre elas e apresentem memoriais. As partes se manifestam, e o juiz sentencia o processo.

Da sentença cabe recurso de apelação para o Tribunal ${ }^{7}$. No Tribunal, a apelação será julgada por um conjunto de profissionais que, via de regra, é composta por três desembargadores, cuja sentença denomina-se acórdão.

Caso o acórdão houver reformado a sentença de forma não unânime, a parte prejudicada poderá opor embargos infringentes, que serão julgados, no caso do Tribunal Regional Federal, pelas Sessões.

\footnotetext{
${ }^{6} \mathrm{~A}$ AJG é um recurso no qual a parte, se ganhar, fica isenta de pagar às custas do processo. Porém, se perder, pode optar entre pagar tais custas ou desistir dele. Para os casos em que se solicita Assistência Judiciária Gratuita, o juiz pode tanto mandar o autor juntar mais documentos para se pronunciar ou pode deferir ou indeferir o pedido de AJG.

${ }^{7}$ Nas ações ajuizadas contra a Fazenda Pública Federal, a sentença cujo valor ultrapassar 60 salários mínimos será submetida ao reexame necessário.
} 
Do acórdão do Tribunal cabe recurso para o STJ e STF. Chama-se de Recurso Especial o que vai para o STJ, e de Recurso Extraordinário o que vai para o STF. Esses recursos devem atender a uma série de requisitos formais para chegarem aos Tribunais Superiores.

Das decisões do STF e do STJ não cabem mais recursos. Com o trânsito em julgado das decisões, o processo retorna à origem, e o juiz manda as partes se manifestarem. Se o processo depender de liquidação, inicia-se quase que um novo processo com todas as fases novamente, com o intuito de quantificar/especificar o direito reconhecido. Após a liquidação e apurado o valor, inicia-se um processo de execução que pode ter de passar por quase todas as fases novamente.

O devedor será citado para pagar ou opor embargos à execução, nos quais poderá ser discutido o valor devido e questões que possam modificar ou extinguir a execução, além de questões formais do processo, como a legitimidade das partes. A parte embargada poderá impugnar os embargos opostos, e frente às divergências, o juiz poderá solicitar à Contadoria Judicial a emissão de parecer com nova elaboração de cálculos.

Caso existam valores incontroversos, a parte poderá requerer o prosseguimento da execução com a expedição de precatório ou $\mathrm{RPV}^{8}$. Caso o juiz indefira, a parte exequente poderá interpor recurso de Agravo de Instrumento, que será analisado pelo Tribunal Regional Federal.

Ao final, o juiz proferirá a sentença dos embargos, contra a qual poderá ser interposto recurso de apelação, que será apreciada por uma Turma do Tribunal Regional Federal. Em sede de embargos à execução não há reexame necessário.

Conforme o caso, contra o acórdão, poderão ser opostos embargos infringentes ou recursos especial e extraordinário.

\footnotetext{
${ }^{8}$ Requisições de Pequeno Valor
} 
Figura 2 - Fases Processo Cível

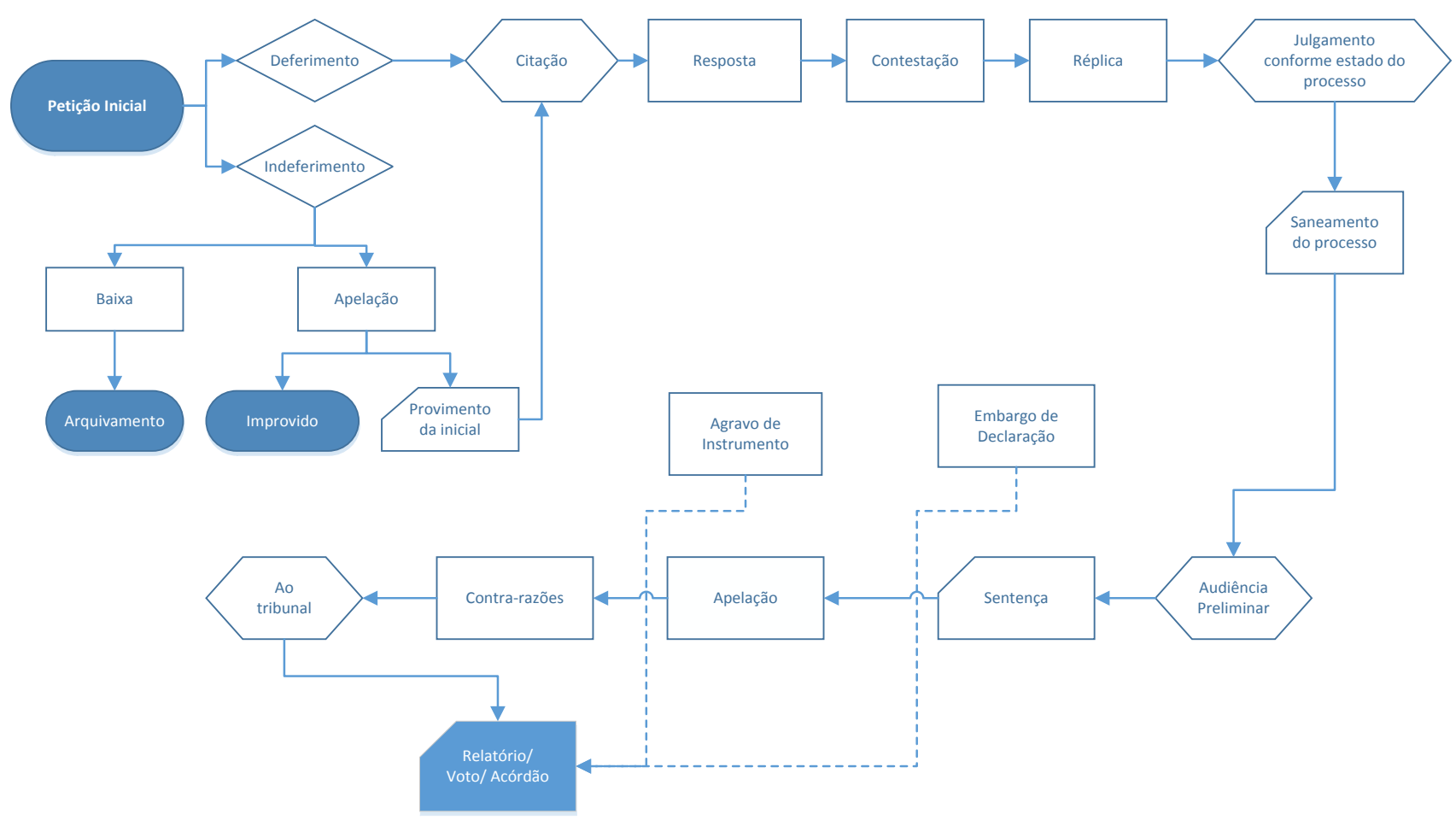

Fonte: Adaptada do Conselho da Justiça Federal (2001).

\subsection{Considerações sobre os trâmites processuais administrativos}

Os processos administrativos referem-se a processos fora da esfera judicial onde são analisadas se as regras específicas do órgão em questão foram seguidas ou não. De acordo com Gasparini (2005, p. 857),

Processo administrativo, em sentido prático, amplo, é o conjunto de medidas jurídicas e materiais praticadas com certa ordem cronologia, necessárias ao registro dos atos da Administração Pública, ao controle do comportamento dos administrados e de seus servidores, a compatibilizar, no exercício do poder de polícia, os interesses público e privado, a punir seus servidores e terceiros, a resolver controvérsias administrativas e a outorgar direitos a terceiros.

Para o propósito deste trabalho, serão analisados os processos administrativos no âmbito da CVM e do Bacen. A descrição sobre os processos sancionadores desses reguladores encontrase nas sessões a seguir.

\subsubsection{Comissão de Valores Mobiliários}

Os processos na CVM podem ser divididos em (i) Processo Administrativo e (ii) Processo Administrativo Sancionador. De acordo com o website do regulador, segue a definição de cada um deles: 
(i) Processo Administrativo: trata-se de uma série de atos preparatórios, sucessivos e coordenados, para a emissão de uma decisão final ou para a solução de uma controvérsia no âmbito administrativo. Esse tipo de processo é instaurado com o intuito de tratar assuntos de interesse dos participantes do mercado de valores mobiliários, dos poderes públicos, da sociedade em geral ou de matéria de interesse da própria CVM e de seus servidores.

(ii) Processo Administrativo Sancionador (PAS): é derivado de uma investigação realizada por meio de processo administrativo de caráter investigatório. É elaborado em uma das áreas técnicas da CVM, para o qual tenham sido encontrados indícios de autoria e materialidade, relativa a alguma irregularidade ocorrida no âmbito do mercado de capitais resultando em acusação. O processo que culminou em acusação (PAS) passa, então, pelo rito processual de intimação, recebimento das defesas e sorteio do relator para julgamento pelo Colegiado da CVM, quando, em caso de condenação, serão aplicadas as penalidades previstas no art. 11 da Lei 6.385/76.

Os PAS são julgados pelo Colegiado da CVM e passam pelos trâmites do rito ordinário ${ }^{9}$. Os Processos Administrativos não sancionadores são considerados de rito sumário ${ }^{9}$ e são julgados diretamente pelas áreas técnicas da autarquia, apreciados em reuniões com o Colegiado.

A Deliberação 538/08 apresenta mais detalhes sobre as fases e procedimentos a serem seguidos nos casos de PAS. Um PAS pode ser iniciado por um Termo de Acusação ou por um Relatório de Inquérito. De acordo com a entrevista feita com Luciana Dias, ex-membro do Colegiado da CVM, "As áreas técnicas podem entender que de acordo com os elementos que eles têm, já existem elementos suficientes de autoria e materialidade para fazer uma acusação. E aí nasce um Termo de Acusação". Por outro lado, ainda de acordo com Dias,

Se houver indícios de irregularidade, mas estiver faltando provas, investigação, a área técnica manda esse material para uma área chamada Superintendência de Processos Sancionadores, SPS, e a Superintendência de Processos Sancionadores vai investigar e abrir um inquérito, uma investigação. Se ela concluir que realmente é necessário, e a maior parte das vezes ela conclui que é necessário fazer um processo sancionador, ela vai escrever um Relatório de Inquérito e não um Termo de Acusação.

Há também a figura do Termo de Compromisso, introduzida pela Lei 6.385/76. De acordo com a lei (Art. 11, inciso VIII, $\S 5^{\circ}$ ):

A Comissão de Valores Mobiliários poderá, a seu exclusivo critério, se o interesse público permitir, suspender, em qualquer fase, o procedimento administrativo instaurado para a apuração de infrações da legislação do mercado de valores mobiliários, se o investigado ou acusado assinar termo de compromisso, obrigando-se a:

I - cessar a prática de atividades ou atos considerados ilícitos pela Comissão de Valores Mobiliários;

II - corrigir as irregularidades apontadas, inclusive indenizando os prejuízos.

De acordo com o profissional Luiz Leonardo Cantidiano:

\footnotetext{
${ }^{9}$ Ver explicação sobre rito sumário e ordinário na seção 2.3 .
} 
Antes do julgamento, ainda quando o processo está na área técnica, quando a defesa é feita, há a possibilidade de o acusado - no Termo de Acusação ou no inquérito, não importa, pedir a celebração de um termo de compromisso. Isto é uma espécie de termo de ajustamento de conduta. Esse pedido é formulado na defesa ou até 30 dias depois da apresentação da defesa, e esse pedido do Termo de Compromisso vai ser apreciado por Comitê do Termo de Compromisso. Este é um Comitê presidido pelo Superintendente Geral com a participação dos diversos superintendentes da CVM. Aprovada essa proposta de celebração de termo de compromisso, o compromisso é assinado e não há prosseguimento do inquérito. Ele fica suspenso até verificar se o compromisso foi cumprido. Em caso positivo, o processo é arquivado. Não há, portanto, julgamento do processo, da acusação e da defesa. Por outro lado, se o Comitê de Termo de Compromisso nega a celebração do compromisso, ele entende que o assunto deve ir a julgamento.

Após essa fase inicial, é feita a apresentação das defesas e em seguida é feito o encaminhamento para o Colegiado e sorteio de um relator. Por fim é feito o julgamento pelo Colegiado da CVM.

Se houver alguma discordância da decisão, por parte da empresa que está sendo acusada, existe a possibilidade de recurso para o $\mathrm{CRSFN}^{10}$.

O Colegiado da CVM é formado pelo presidente e quatro diretores, reúne-se com a periodicidade semanal, em sessão reservada, para analisar as matérias de competência do regulador, atuando como órgão máximo de deliberação.

Sobre a composição do CRSFN e suas deliberações, regimento interno desse órgão menciona (Portaria MF n. 68, 2016):

Art. $2^{\circ}$ O CRSFN será integrado por oito Conselheiros titulares e respectivos suplentes, de reconhecida capacidade técnica e notório conhecimento especializado nas matérias de competência do Conselho, observada a seguinte composição:

I - dois indicados pelo Ministério da Fazenda;

II - um indicado pelo Banco Central do Brasil;

III - um indicado pela Comissão de Valores Mobiliários; e

IV - quatro indicados, em lista tríplice, pelas entidades representativas dos mercados financeiro e de capitais.

Art. 20. O CRSFN deliberará quando presentes três quartos de seus membros, e as deliberações serão tomadas por maioria simples, cabendo ao presidente da sessão também o voto de qualidade.

Art. 24. $\S 4^{\circ}$. Na votação, o Presidente tomará, sucessivamente, o voto do Relator, dos que tiveram vista dos autos e dos demais Conselheiros, a partir do primeiro sentado à esquerda do Relator, e votará por último, anunciando, em seguida, o resultado do julgamento.

Sobre os processos que não se enquadram como PAS, esses relacionam-se a assuntos diversos, e é uma das formas do regulador de atuar na fiscalização. As Superintendências técnicas são responsáveis pelo seu julgamento. No caso desse processo, é possível haver recurso, por parte do acusado, para o próprio Colegiado da CVM.

\footnotetext{
${ }^{10}$ Conselho de Recursos do Sistema Financeiro Nacional.
} 
Com relação à atuação dos membros do Colegiado, tanto nos casos de PAS quanto dos não sancionadores, a entrevistada Luciana Dias menciona:

Parte substancial dos processos administrativos não sancionadores são resolvidas por decisão da Superintendência (quem tem a relatoria desses processos são as Superintendências). Então, uma parte substancial do trabalho é diferente porque o Colegiado não é o relator desses processos. Eles chegam relatados pelas Superintendências. Agora, tem um pequeno grupo de processos não sancionadores, que o Colegiado relata. Nesses processos que o Colegiado relata, as funções são muito parecidas. Porque você vai escrever um relatório e escrever um voto tomando uma decisão a respeito daquilo. E, por isso, a análise do Colegiado é parecida, não é diferente. Você tem que tomar cuidados diferentes, porque no processo sancionador você tem uma série de prerrogativas que você precisa dar para a parte, a possibilidade de defesa e tal. Mas a função mesmo no dia a dia é escrever um relatório e um voto.

Figura 3 - Fases Processo Administrativo Sancionador - CVM

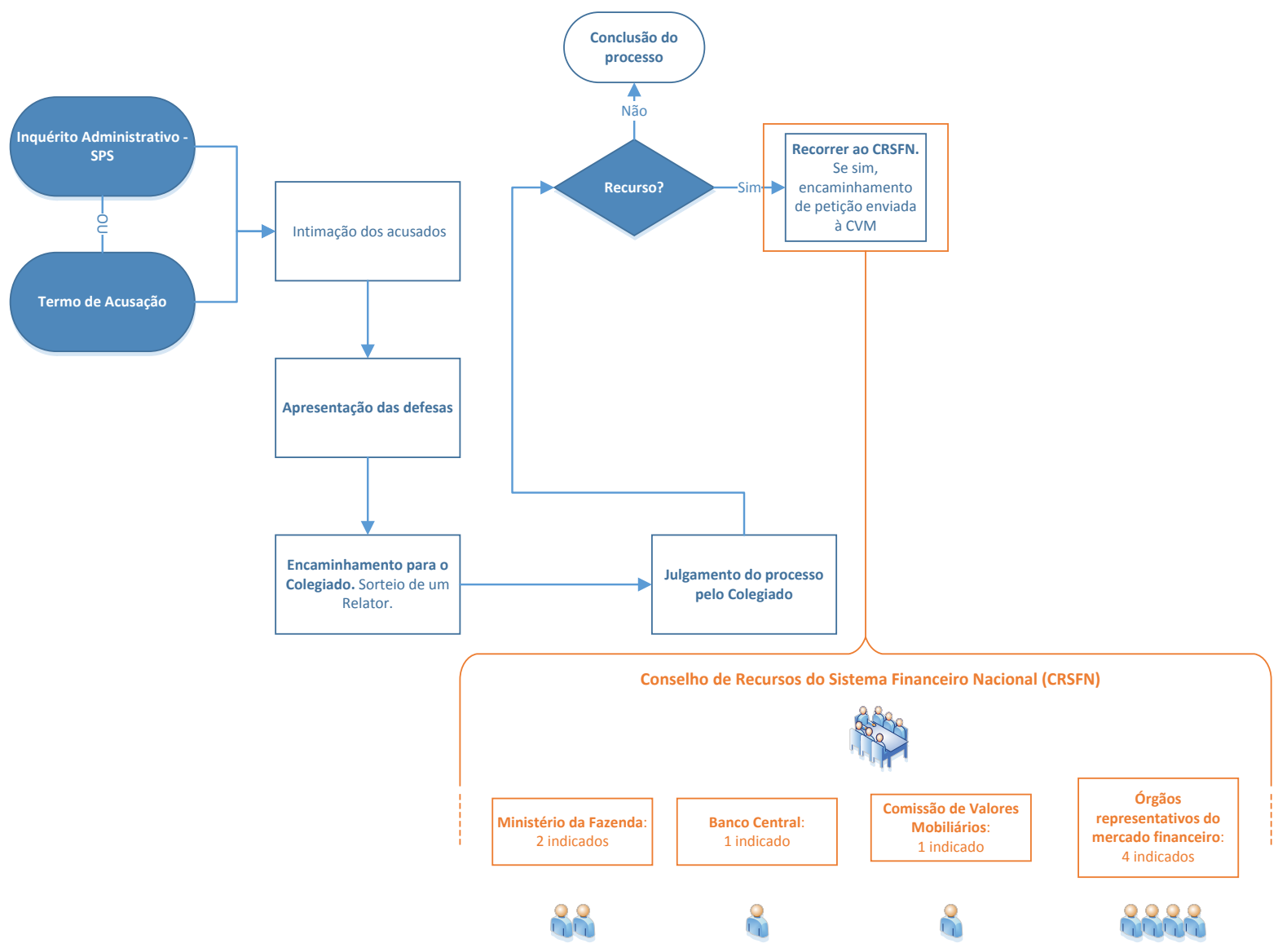

Fonte: Elaborada por esta autora com base nas informações do website do regulador. 


\subsubsection{Banco Central do Brasil}

Com relação ao Banco Central do Brasil, como parte de suas atividades relacionadas ao sistema de supervisão e fiscalização do Sistema Financeiro Nacional, ele dispõe de instrumentos prudenciais preventivos e punitivos que consistem em (BACEN, 2015):

a) medidas prudenciais preventivas previstas na Resolução 4.019/11;

b) medidas prudenciais preventivas previstas em outras normas;

c) exigência de plano de solução ou regularização;

d) processo administrativo e punitivo;

e) medidas cautelares;

f) lavratura de termo de comparecimento; e

g) admissão de depósito vinculado.

O Bacen tem, portanto, poder legal para instaurar processo administrativo punitivo quando constatada uma infração à norma legal ou regulamentar, por parte das instituições supervisionadas e empresas de auditoria dessas entidades.

De acordo com o website $^{11}$ do regulador, os processos administrativos compreendem as seguintes fases:

1) instauração: a ciência da intimação ou do auto de infração pelo acusado;

2) defesa: apresentação da contestação pelo acusado, por escrito e instruída com os documentos em que se fundamenta;

3) exame do processo: análise dos autos da instauração e da defesa;

4) decisão de primeira instância: decisão administrativa proferida pelo Bacen;

5) recurso: apresentação de contestação da decisão de primeira instância ao Conselho de Recursos do Sistema Financeiro Nacional (CRSFN);

6) decisão de segunda instância: decisão administrativa proferida pelo CRSFN.

\footnotetext{
${ }^{11}$ BACEN (2015)
} 
Figura 4 - Fases processo Administrativo - Bacen

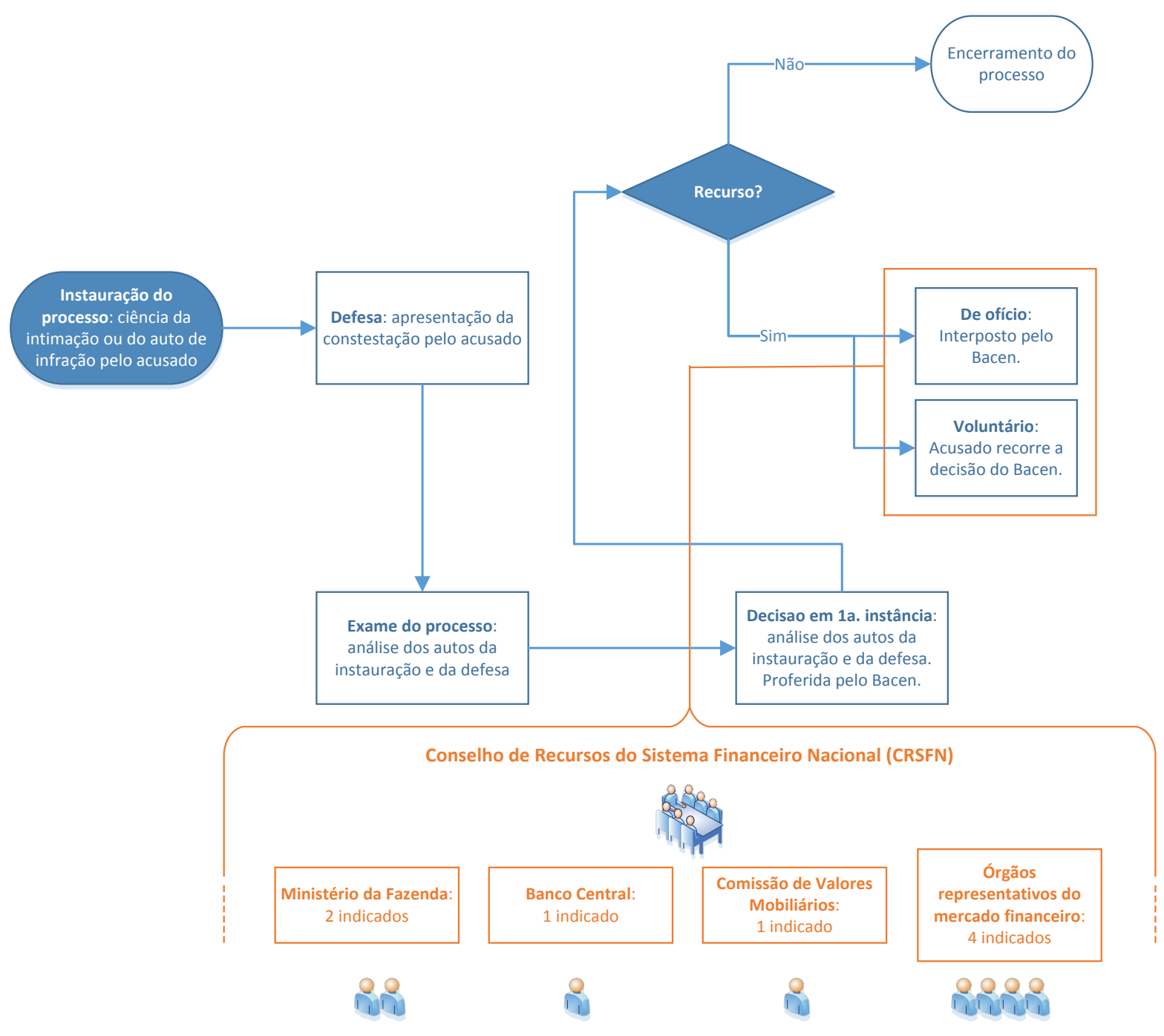

Fonte: Elaborada por esta autora com base nas informações do website do regulador

De acordo com o regulador, após instaurado o processo, mediante a ciência do auto de infração pelo acusado, a defesa pode começar na preparação de documentos para sua fundamentação. Após apresentação da defesa, o processo é analisado, e desse estudo resulta parecer técnico com proposta de solução. Elaborado o parecer, o processo é submetido ao gerente-técnico/chefe de subunidade para manifestação e:

a) encaminhamento ao Comitê de Análise de Proposta de Decisão de Processos Administrativos Punitivos - Codep; ou

b) decisão, nos limites de sua alçada. 
As alçadas decisórias em processos administrativos punitivos do Banco Central estão distribuídas da seguinte forma ${ }^{12}$ :

- Gerentes-técnicos/chefes de subunidade do Decap: competência para decidir sobre arquivamento e aplicação das penalidades de advertência e multa no valor de até R\$ 500.000,00 (quinhentos mil reais);

- Chefe do Decap ${ }^{13}$ : arquivamento e aplicação das penas de advertência, suspensão e multa no valor de até $\mathrm{R} \$ 2.000 .000,00$ (dois milhões de reais);

- Diretor de Organização do Sistema Financeiro e Controle de Operações do Crédito Rural: arquivamento e imposição das penas de advertência, proibição para atuar, suspensão e inabilitação para o exercício de cargos de direção na administração e gerência em instituições autorizadas a funcionar pelo Banco Central do Brasil, e de multa no valor superior a $\mathrm{R} \$ 2.000 .000,00$ (dois milhões de reais);

- Diretoria Colegiada do Banco Central do Brasil: cassação da autorização de funcionamento de administradoras de consórcio;

- Conselho Monetário Nacional: cassação da autorização de funcionamento de instituições autorizadas a funcionar pelo Banco Central do Brasil, exceto administradoras de consórcio.

Após a aprovação da proposta pelo Codep, o processo é encaminhado à autoridade competente. O acusado é intimado da decisão do Bacen, de primeiro grau, e da possibilidade de recurso ao CRSFN, essa considerada como segunda instância administrativa.

Existem dois tipos de recursos: (i) de ofício e (ii) voluntário. O recurso de ofício é interposto pelo Banco Central do Brasil em face de decisão que concluir pela não aplicação de penalidades. O recurso voluntário permite ao acusado recorrer da decisão imposta pelo Banco Central do Brasil.

Para o caso desse regulador, portanto, as decisões no âmbito do CRSFN englobam no mínimo 6 conselheiros. É importante mencionar que tanto para o Colegiado da CVM quanto para o CRSFN, os profissionais envolvidos no processo decisório não são juízes de direito. Tratam-se de profissionais, com conhecimento técnico específico sobre o SFN e o Mercado de Valores Mobiliário que exercem uma função julgadora no âmbito desses reguladores.

Por esses profissionais terem experiências distintas, é possível que acarretem consequências diferentes no desfecho dos processos.

\footnotetext{
${ }^{12}$ Fonte: http://www4.bcb.gov.br/fis/PAD/port/Menu/ProcessoAdministrativo.asp

${ }^{13}$ Departamento de Controle e Análise de Processos Administrativos Punitivos
} 


\subsection{Coleta e Seleção dos Processos Judiciais e Administrativos}

Como a intenção da pesquisa está relacionada com a análise de processos contra as firmas de auditoria de forma geral, houve a necessidade de dividir a busca em processos judiciais cíveis e processos administrativos (que envolvam a atuação de reguladores).

Com relação aos processos judiciais cíveis, foram feitas buscas nos websites das seguintes instituições:

- Tribunal Regional Federal - TRF

- Superior Tribunal de Justiça - STJ

- Supremo Tribunal Federal - STF

Além desses, foram feitas buscas nos websites dos Tribunais de Justiça de determinados Estados brasileiros. Isso porque, para a finalidade desta pesquisa, entende-se que os principais processos, de âmbito nacional, são discutidos nos tribunais próximos às sedes das empresas envolvidas nessas discussões.

Com base no cadastro das companhias abertas que estão sob a autarquia da CVM, é possível verificar que há uma concentração de sedes de empresas na região sudeste e sul (abrangem aproximadamente $90 \%$ das companhias abertas registradas na CVM).

Tabela 2 - Sedes companhias abertas

\begin{tabular}{lcc}
\hline Estado & $\begin{array}{c}\text { Quantidade } \\
\text { Cias } \\
\text { Abertas }^{14}\end{array}$ & Representatividade \\
\hline SP - São Paulo & 292 & $46,9 \%$ \\
\hline RJ - Rio de Janeiro & 122 & $19,6 \%$ \\
\hline MG - Minas Gerais & 42 & $6,8 \%$ \\
\hline RS - Rio Grande do Sul & 40 & $6,4 \%$ \\
\hline PR - Paraná & 29 & $4,7 \%$ \\
\hline SC - Santa Catarina & 27 & $4,3 \%$ \\
\hline BA - Bahia & 16 & $2,6 \%$ \\
\hline CE - Ceará & 11 & $1,8 \%$ \\
\hline DF - Distrito Federal & 10 & $1,6 \%$ \\
\hline ES - Espírito Santo & 5 & $0,8 \%$ \\
\hline
\end{tabular}

\footnotetext{
${ }^{14}$ Para essa compilação de dados, foram consideradas as companhias abertas com cadastro ativo. Não foram consideradas companhias estrangeiras e fundos de investimentos.
} 


\begin{tabular}{l|c|c}
\hline Estado & $\begin{array}{c}\text { Quantidade } \\
\text { Cias } \\
\text { Abertas }^{14}\end{array}$ & Representatividade \\
\hline PE - Pernambuco & 5 & $0,8 \%$ \\
\hline PA - Pará & 4 & $0,6 \%$ \\
\hline MA - Maranhão & 3 & $0,5 \%$ \\
\hline RN - Rio Grande do Norte & 3 & $0,5 \%$ \\
\hline AM - Amazonas & 2 & $0,3 \%$ \\
\hline GO - Goiás & 2 & $0,3 \%$ \\
\hline MS - Mato Grosso do Sul & 2 & $0,3 \%$ \\
\hline MT - Mato Grosso & 2 & $0,3 \%$ \\
\hline PB - Paraíba & 2 & $0,3 \%$ \\
\hline SE - Sergipe & 2 & $0,3 \%$ \\
\hline TO - Tocantins & 1 & $0,2 \%$ \\
\hline Total & $\mathbf{6 2 2}$ & \\
\hline
\end{tabular}

Fonte: http://sistemas.cvm.gov.br

Nesse caso, foram feitas consultas aos Tribunais de Justiça dos seguintes Estados:

Tabela 3 - Websites dos tribunais de justiça consultados

\begin{tabular}{c}
\hline Tribunais de Justiça Consultados \\
\hline Tribunal de Justiça do Estado do São Paulo \\
Tribunal de Justiça do Estado de Rio de Janeiro \\
Tribunal de Justiça do Estado do Espírito Santo \\
Tribunal de Justiça do Estado de Minas Gerais \\
Tribunal de Justiça do Estado do Rio Grande do Sul \\
Tribunal de Justiça do Estado do Paraná \\
\hline Tribunal de Justiça do Estado de Santa Catarina \\
\hline Tribunal de Justiça do Estado do Amazonas \\
\hline Tribunal de Justiça do Distrito Federal \\
\hline Tribunal de Justiça do Estado da Bahia \\
Tribunal de Justiça do Estado do Ceará \\
\hline Fonte: Elaborada por esta autora
\end{tabular}

Com relação às consultas nos websites nos Tribunais de Justiça específicos, o foco da pesquisa consistiu em processos que estão sendo discutidos em $2^{\mathrm{a}}$ Instância. Isso porque, na $1^{\mathrm{a}}$ Instância, as decisões cabem recurso e contemplam a decisão de apenas um juiz. Como o propósito da pesquisa é capturar a decisão em um estágio mais evoluído do processo, optou-se pela $2^{\mathrm{a}}$ Instância. 
Após a definição dos websites que seriam consultados para obter a população de processos, as buscas foram feitas pelos nomes das partes envolvidas nos processos, no caso, as Big4, especificamente as empresas de "auditoria independente". Não foram consideradas, por exemplo, buscas pelo nome das empresas de consultoria, outsourcing, entre outras.

A busca consistiu na obtenção de processos nos quais as empresas de auditoria figurariam como acusadas nos processos. Ver os Apêndices D, E e F com o protocolo das buscas feitas tanto no âmbito cívil quanto no administrativo. A data base para a busca dos processos e consequentemente a data de corte para construção do banco de dados foi 25 de agosto de 2016.

Após a identificação do nome da empresa de auditoria, foram desconsiderados os seguintes processos para o propósito desta pesquisa:

- Processos tributários. Normalmente se referem a discussões com os respectivos municípios em que atuam.

- Processos relacionados à recuperação judicial e espólio.

- Cobranças por determinadas prestações de serviços.

Com base nessa lista de processo, foram excluídos, ainda, os processos que não estão relacionados com as responsabilidades do auditor, por não guardarem relação com o objetivo do trabalho de identificar gaps de razoabilidade. Nesse contexto, inclui-se, por exemplo, descumprimento legais relacionados ao rodízio da auditoria ou mesmo descumprimento de questões de independência.

Foram selacionados para análise os documentos que continham manifestações de juízes no decorrer do processo, nesse caso os acórdãos.

$\mathrm{Na}$ Tabela abaixo, encontra-se um resumo das informações dos processos selecionados: 
Tabela 4 - Processos cíveis selecionados

\begin{tabular}{|c|c|c|c|c|c|}
\hline $\mathbf{N}^{\mathbf{0}}$ & $\begin{array}{l}\text { Número do } \\
\text { Processo }\end{array}$ & Partes & Vara/ Tribunal & Status & Companhia \\
\hline 1 & $\begin{array}{l}2017526- \\
58.2014 .8 .26 . \\
0000\end{array}$ & $\begin{array}{l}\text { Agravado: Deloitte } \\
\text { Touche Tohmatsu } \\
\text { Auditores Independentes }\end{array}$ & $\begin{array}{l}\text { TJSP - } 1^{\mathrm{a}} \\
\text { Câmara de } \\
\text { Direito Privado }\end{array}$ & $\begin{array}{l}\text { Arquivado } \\
\text { administrativamente }\end{array}$ & Engepack \\
\hline 2 & $\begin{array}{l}\text { Apl. 9161946- } \\
23.2003 .8 .26 . \\
0000\end{array}$ & $\begin{array}{l}\text { Apelado: } \\
\text { Pricewaterhousecoopers } \\
\text { Auditores Independentes } \\
\text { S/c }\end{array}$ & $\begin{array}{l}\text { TJSP }-14^{\circ}-14^{\mathrm{a}} \\
\text { Câmara de } \\
\text { Direito Privado }\end{array}$ & $\begin{array}{l}\text { Retornou dos Sup. } \\
\text { Tribunais. }\end{array}$ & $\begin{array}{l}\text { Banco } \\
\text { Noroeste }\end{array}$ \\
\hline 3 & $\begin{array}{l}0123784- \\
98.2006 .8 .26 \\
0100\end{array}$ & $\begin{array}{l}\text { Apdo/Apte: Ernst \& } \\
\text { Young Terco Auditores } \\
\text { Independentes S/s }\end{array}$ & $\begin{array}{l}\text { TJSP - } 2^{\mathrm{a}} \text { Vara } \\
\text { Cível }\end{array}$ & Encerrado. & Banco Santos \\
\hline 4 & $\begin{array}{l}1028724- \\
03.2014 .8 .26 \\
0100\end{array}$ & $\begin{array}{l}\text { Apelado: Ernst \& Young } \\
\text { Terco Auditores } \\
\text { Independentes S/s }\end{array}$ & $\begin{array}{l}25^{\mathrm{a}} \text { Vara Cível } \\
\text { - Foro Central } \\
\text { Cível }\end{array}$ & - & $\begin{array}{l}\text { Sociedade } \\
\text { Hebraico } \\
\text { Brasileira } \\
\text { Renascença }\end{array}$ \\
\hline 5 & $\begin{array}{l}0002074- \\
13.2001 .4 .01 . \\
3400 \\
\text { (velha -: } \\
2001.34 .00 .00 \\
2072-0 \text { ) }\end{array}$ & $\begin{array}{l}\text { Apelado: Ernst \& Young } \\
\text { Terco Auditores } \\
\text { Independentes S/s }\end{array}$ & $\begin{array}{l}\text { TRF } 1-7^{\mathrm{a}} \text { Vara } \\
\text { federal }\end{array}$ & $\begin{array}{l}\text { No(a) Coord. } \\
\text { Registro Info. } \\
\text { Processuais }\end{array}$ & $\begin{array}{l}\text { Banco } \\
\text { Econômico }\end{array}$ \\
\hline 6 & $\begin{array}{l}2103824- \\
53.2014 .8 .26 \\
0000\end{array}$ & $\begin{array}{l}\text { Agravante: KPMG } \\
\text { Auditores Independentes }\end{array}$ & $\begin{array}{l}\text { Comarca de São } \\
\text { Paulo / Foro } \\
\text { Central Cível / } 1^{\mathrm{a}} \\
\text { Vara }\end{array}$ & Julgado. & Banco BVA \\
\hline 7 & $\begin{array}{l}2212188- \\
22.2014 .8 .26 \\
0000\end{array}$ & $\begin{array}{l}\text { Agravante: KPMG } \\
\text { Auditores Independentes }\end{array}$ & $\begin{array}{l}\text { Comarca de São } \\
\text { Paulo / Foro } \\
\text { Central Cível / } \\
25^{\mathrm{a}} \text { Vara Cível }\end{array}$ & Julgado. & Basf \\
\hline 8 & $\begin{array}{l}\text { AREsp n } \\
98643 / \mathrm{SP} \\
(2011 / 019829 \\
2-8)\end{array}$ & $\begin{array}{l}\text { Agravante: KPMG } \\
\text { Auditores Independentes }\end{array}$ & STJ & $\begin{array}{l}\text { Remetidos os autos } \\
\text { (em grau de recurso) } \\
\text { para STF }\end{array}$ & $\begin{array}{l}\text { Banco } \\
\text { Nacional }\end{array}$ \\
\hline 9 & $\begin{array}{l}\text { AREsp } n^{\circ} \\
88568 / \\
\operatorname{SP}(2011 / 0197 \\
588-5)\end{array}$ & $\begin{array}{l}\text { Agravante: KPMG } \\
\text { Auditores Independentes }\end{array}$ & STJ & $\begin{array}{l}\text { Remetidos os autos } \\
\text { (em grau de recurso) } \\
\text { para STF }\end{array}$ & $\begin{array}{l}\text { Banco } \\
\text { Nacional }\end{array}$ \\
\hline 10 & $\begin{array}{l}\text { AREsp no } \\
140538 / \\
\operatorname{DF}(2012 / 004 \\
0106-7)\end{array}$ & $\begin{array}{l}\text { Agravado: KPMG } \\
\text { Auditores Independentes }\end{array}$ & STJ & $\begin{array}{l}\text { Processo baixado } \\
\text { eletronicamente } \\
\text { aoTJDFT }\end{array}$ & $\begin{array}{l}\text { Banco } \\
\text { Nacional }\end{array}$ \\
\hline 11 & $\begin{array}{l}\text { REsp } n^{\circ} \\
1283737 / \\
\mathrm{DF}(2011 / 022 \\
3035-6)\end{array}$ & $\begin{array}{l}\text { Recorrido: KPMG } \\
\text { Auditores Independentes }\end{array}$ & STJ & $\begin{array}{l}\text { Remetidos os autos } \\
\text { (em grau de recurso) } \\
\text { para STF }\end{array}$ & $\begin{array}{l}\text { Banco } \\
\text { Nacional }\end{array}$ \\
\hline
\end{tabular}

Fone: Elaborada por esta autora

Com relação aos processos administrativos, as buscas foram feitas diretamente nos websites da CVM e do Banco Central do Brasil. 
No caso da CVM, as buscas foram direcionadas para 'processos sancionadores julgados' pelos nomes das empresas de auditoria em questão. No caso do Bacen, as buscas foram direcionadas para 'processos administrativos punitivos' e, em seguida, para 'decisões proferidas pelo Conselho de Recursos do Sistema Financeiro Nacional (CRSFN)', também pelos nomes das empresas de auditoria em questão ${ }^{15}$. Portanto, a população considerada para este trabalho foram os processos disponíveis para consulta no website dos reguladores.

Com base nisso, foram selecionados os processos nos quais as empresas de auditoria estavam no papel de acusadas. Seguem duas tabelas que sumarizam esses processos. Nos Apêndices G e $\mathrm{H}$ encontram-se também informações sobre a ementa e a decisão dos processos administrativos da CVM e do Bacen, respectivamente.

Tabela 5 - Processos administrativos selecionados - CVM

\begin{tabular}{ll|l|c|l}
\hline \multicolumn{1}{l}{ Processo } & Data & Acusados & Companhia \\
\hline $\mathbf{1}$ & RJ2010/16893 & $6 / 7 / 2011$ & DTT & Saraiva S/A - Livreiros Editores \\
\hline $\mathbf{2}$ & $17 / 00$ & $4 / 15 / 2004$ & E\&Y & Semp Toshiba S/A, \\
\hline $\mathbf{3}$ & RJ2008/9120 & $10 / 13 / 2009$ & E\&Y & All - América Latina Logística S/A \\
\hline $\mathbf{4}$ & $15 / 99$ & $8 / 2 / 2001$ & PwC & Fundos Administrados pelo Unibanco \\
\hline $\mathbf{5}$ & $09 / 03$ & $1 / 25 / 2006$ & PwC & Bebidas Antarctica Polar S/A \\
\hline $\mathbf{6}$ & $15 / 90$ & $8 / 24 / 2010$ & PwC & Barretto de Araújo Produtos de Cacau S.A. \\
\hline $\mathbf{7}$ & RJ2001/8029 & $5 / 6 / 2004$ & KPMG & Parcom Participações S/A \\
\hline $\mathbf{8}$ & $05 / 02$ & $8 / 5 / 2004$ & KPMG & Ribeirão Preto Water Park S/A \\
\hline $\mathbf{9}$ & RJ2009/12495 & $12 / 1 / 2010$ & KPMG & Perdigão S/A, atual BRF - Brasil Foods S/A \\
\hline $\mathbf{1 0}$ & $31 / 00$ & $10 / 7 / 2003$ & KPMG & Lojas Arapuã S/A \\
\hline $\mathbf{1 1}$ & RJ2013/9762 & $25 / 9 / 2015$ & KPMG & FIDC Union \\
\hline
\end{tabular}

Fonte: Elaborada por esta autora

Tabela 6 - Processos administrativos selecionados - Bacen

\begin{tabular}{ll|c|l|l}
\hline \multicolumn{1}{|c|}{ Processo } & Data & Acusados & Companhia \\
\hline $\mathbf{1}$ & Processo BCB 0001046032 & $13 / 12 / 2005$ & Deloitte & Banco Excel Econômico S.A. \\
\hline $\mathbf{2}$ & Processo BCB 0201144611 & $08 / 04 / 2010$ & KPMG & Banco Bandeirantes \\
\hline $\mathbf{3}$ & Processo BCB 0501284933 & $05 / 12 / 2012$ & Ernst \& Young & Banco Santos S.A. \\
\hline $\mathbf{4}$ & Processo BCB 1001494887 & $24 / 11 / 2015$ & Deloitte & Banco Panamericano S.A. \\
\hline
\end{tabular}

Fonte: Elaborada por esta autora

Com relação aos resultados da busca por processos de origem do Bacen, foram obtidos 3 acórdãos que apresentaram conteúdo muito sucinto e não foi possível, apenas por meio desses

\footnotetext{
${ }^{15}$ Ver Apêndices D e E com o protocolo sobre as buscas dos processos administrativos.
} 
documentos, fazer a análises pertinentes para os objetivos deste trabalho. Na tentativa de obter mais informações sobre esses casos, foi aberta uma solicitação de melhores informações sobre a conclusão dos respectivos processos, mesmo que fosse o acórdão da decisão da primeira instância, no website do governo federal, por meio do sistema eletrônico do serviço de informação ao cidadão, com respaldo na Lei de Acesso à Informação. A resposta obtida do Departamento de Atendimento Institucional (Deati) do Bacen, no dia 02/09/2016, foi a seguinte:

O Banco Central não divulga as decisões de primeira instância de processos administrativos punitivos, em razão dos sigilos bancário e fiscal dos envolvidos. Ressalte-se que o edital de penalidades aplicadas no âmbito dos processos administrativos é informação pública (publicado no Diário Oficial da União).

Nesse caso, portanto, foram analisados 4 (quatro) processos do CRSFN oriundos do Bacen.

Aqui, é importante mencionar que ao fazer a busca pelos acórdãos proferidos pelo CRSFN, tem-se a decisão em última instância do SFN. Nesse caso, pode haver processos que são oriundos tanto da CVM quanto do Bacen.

Para os casos que são originados da CVM, é possível obter os processos julgados pelo seu Colegiado e, caso haja um recurso desse julgamento, é possível obter também o acórdão do julgamento em última instância, essa que seria no CRSFN.

Por outro lado, no caso dos acórdãos de processos do Bacen, é possível obter apenas as decisões da última instância, no CRSFN.

Não foi escopo deste trabalho pesquisar processos contra auditores nos CRCs ou CFC.

$\mathrm{Na}$ Tabela abaixo encontram-se os processos que foram originados pela CVM que sofreram recurso sobre a decisão do Colegiado. Para esses casos, os acórdãos do CRSFN foram analisados em conjunto com os do Colegiado. 
Tabela 7 - Processos originados CVM - CRSFN

\begin{tabular}{|c|c|c|c|c|c|}
\hline & Auditoria & Acórdão & Processo CVM & Data & Empresa \\
\hline $\mathbf{1}$ & KPMG & $\begin{array}{l}\text { Acórdão CRSFN } \\
5653 / 04\end{array}$ & Processo CVM 31/00 & $14 / 12 / 2004$ & Lojas Arapuã \\
\hline 2 & KPMG & $\begin{array}{l}\text { Acórdão CRSFN } \\
11533 / 15\end{array}$ & $\begin{array}{l}\text { Processo CVM } \\
\text { RJ2009-12495 }\end{array}$ & $26 / 05 / 2015$ & Perdigão \\
\hline 3 & DTT & $\begin{array}{l}\text { Acórdão CRSFN } \\
11333 / 14\end{array}$ & $\begin{array}{l}\text { Processo CVM RJ- } \\
\text { 2010-16893 }\end{array}$ & $26 / 08 / 2014$ & Saraiva \\
\hline & $\mathrm{PwC}$ & Acórdão 8373 & Processo CVM 09/03 & $27 / 05 / 2008$ & $\begin{array}{l}\text { Bebidas } \\
\text { Antarctica } \\
\text { Polar S/A }\end{array}$ \\
\hline & $\mathrm{PwC}$ & Acórdão 11331 & Processo CVM 15/1990 & $26 / 08 / 2014$ & BAP \\
\hline & $\mathrm{PwC}$ & $\begin{array}{l}\text { Acórdão CRSFN } \\
3809 / 02\end{array}$ & Processo CVM 15/99 & $24 / 10 / 2002$ & Unibanco \\
\hline 7 & $\mathrm{E} \& \mathrm{Y}$ & $\begin{array}{l}\text { Acórdão CRSFN } \\
11236 / 14\end{array}$ & $\begin{array}{l}\text { Processo CVM RJ- } \\
2008-9120\end{array}$ & $18 / 03 / 2014$ & ALL \\
\hline & E\&Y & $\begin{array}{l}\text { Acórdão CRSFN } \\
8325 / 08\end{array}$ & $\begin{array}{l}\text { Processo CVM IA } \\
2000-17\end{array}$ & $26 / 03 / 2008$ & Semp Toshiba \\
\hline
\end{tabular}

Fonte: Elaborada por esta autora 


\section{PLATAFORMA TEÓRICA}

\subsection{O papel do auditor}

Watts e Zimmerman (1983), em seu trabalho sobre problemas de agência, auditoria e a teoria da firma, analisaram o papel da auditoria independente no contexto do desenvolvimento da história das sociedades empresariais. De acordo com eles, a existência pode ser associada ao desenvolvimento das sociedades empresariais, por volta de 1200 e evoluiu gradualmente para o tipo de auditoria requerido pela Inglaterra em 1844.

Esses autores, mencionando o trabalho de Jensen e Meckling (1976), argumentam que a firma é formada por um conjunto de contratos que oferecem diversos incentivos para comportamentos oportunistas e a administração, na tentativa de reduzir esses comportamentos, contrata os auditores, deixando claro, portanto, uma função de monitoramento.

Watts e Zimmerman (1983) ainda complementam que a auditoria terá sucesso se, além de reduzir o oportunismo por parte dos funcionários da empresa, o auditor reportar à administração as brechas contratuais encontradas em seu trabalho, fornecendo, nesse ponto, uma relação com a independência do profissional.

Aqui é inevitável a comparação entre o conceito de sucesso de auditoria, de Watts e Zimmerman (1983), e o conceito de qualidade de auditoria de DeAngelo (1981, p. 186), trazido pouco anos antes: "A qualidade dos serviços de auditoria é definida como uma avaliação do mercado da probabilidade conjunta de que o auditor (a) descubra uma falha no sistema de contabilidade do cliente e (b) comunique essa falha"16 (tradução livre desta autora).

Nota-se, portanto, pelo trabalho de Watts e Zimmerman (1983), que há evidências históricas da utilização da auditoria como mecanismo de monitoramento, antes de qualquer lei societária ou regulação de mercado de capitais, visando à redução dos custos de agência (Braunbeck \& Carvalho, 2012, p. 304).

Além do aspecto da função de monitoramento abordada pelos autores, eles ainda trouxeram contribuições relacionadas à independência, quando mencionam que o mercado oferece

16 "The quality of audit services is defined to be the market-assessed joint probability that a given auditor will both (a) discover a breach in the client's accounting system, and (b) report the breach." 
mecanismos de incentivos para que os auditores sejam independentes (Watts \& Zimmerman, 1981).

O desenvolvimento da atividade da auditoria ao longo dos últimos anos trouxe consigo também a evolução da discussão de seu papel. Atualmente, mais abrangente do que relacionar a auditoria com a atividade de monitoramento, é associar seu papel a de um intermediário informacional.

De acordo com Porter (1990), a atividade de auditoria existe para prover a sociedade com um serviço especializado necessário para ela. A especialização existe para satisfazer a demanda para o monitoramento independente do accountability dos relatórios fornecidos e pelo comportamento dos negócios sobre aqueles que influnciam a sociedade por meio de recursos. Ainda segundo a autora, os auditores são, portanto, uma parte integral no processo de accountability requerido pelas organizações econômicas. Embora essa definição tenha evoluído com o passar dos anos e tenha se tornado demasiadamente abrangente, é importante ressaltar nessa ideia o papel do auditor como intermediário informacional.

Healy e Palepu (2001) mencionam que uma variedade de fatores institucionais e econômicos determina quando um contrato, uma regulação ou mesmo os intermediários informacionais eliminam a assimetria informacional. Contratos ótimos entre empresários e investidores podem fornecer incentivos para a divulgação completa de informações privadas, na tentativa de mitigar esse problema. Nesse caso, até mesmo o regulador poderia impor a divulgação de todas as informações privadas. Como essa situação é inexistente para os mercados atuais, existe uma demanda relevante para a atividade a ser exercida pelos intermediários informacionais. No contexto de assimetria da informação contábil no mercado financeiro, Lopes e Martins (2005, p. 31) reforçam uma ideia simples sobre o papel do auditor:

Os auditores são mecânicos informacionais na tentativa de fornecer "atestados" de fidedignidade das demonstrações da empresa para os investidores, que não têm o mesmo acesso à informação que os administradores possuem. Os intermediários informacionais, como auditores, agências de rating, analistas de mercado etc., procuram reduzir a assimetria entre os administradores e os acionistas.

No contexto do papel do auditor como agente redutor da assimetria informacional, Sunder (2014, p. 138) considera as seguintes questões sobre a contratação do auditor:

(i) Somente quando os custos de agência tornam-se altos, devido às dificuldades de controle mútuo direto, um auditor é contratado;

(ii) A introdução de um terceiro agente, em uma relação de agência entre os dois primeiros, dá origem a dois novos relacionamentos e aos custos de agência associados que não existiam antes. 
De acordo com o Conselho Federal de Contabilidade (CFC, 2009a), o objetivo da auditoria é aumentar o grau de confiança nas demonstrações contábeis por parte dos usuários, e isso é alcançado mediante a expressão da opinião de um auditor de que as demonstrações foram elaboradas em todos os seus aspectos relevantes, em conformidade com uma estrutura de relatório financeiro aplicável.

A definição sobre o objetivo da auditoria, de acordo com o CFC, alinhado às normas internacionais de auditoria, faz referência também ao seu papel de intermediário informacional quando menciona o fato dessa atividade aumentar o grau de confiança nas demonstrações por parte de seus usuários, e isso pode ser verificado por meio do produto da auditoria, que é seu relatório ("atestado" de fidedignidade, mencionado por Lopes \& Martins, 2005).

\subsection{Objetivos do auditor e as normas de auditoria no Brasil}

No Brasil, são utilizadas as normas internacionais de auditoria. O Ibracon é o órgão que, em conjunto com o CFC, é responsável pela tradução e revisão das normas internacionais de auditoria, emitidas pelo IFAC.

Esses dois órgãos têm desempenhado um papel crucial no desenvolvimento da profissão contábil no Brasil. Eles definiram as normas de contabilidade, principalmente pelo Comitê de Pronunciamentos Contábeis (CPC). As normas de ética e de auditoria resultam dos esforços conjuntos de ambas as organizações e são emitidas pelo CFC. Além disso, esses órgãos estabelecem os requisitos de educação e qualificação para os seus membros, desenvolvem e oferecem exames, bem como programas de desenvolvimento profissional contínuo e garantem o controle de qualidade por meio de um programa de revisão de pares (World Bank, 2013).

As normas internacionais de auditoria são denominadas ISAs e suas equivalentes no Brasil são as NBCs, que orientam tanto questões técnicas quanto profissionais. A obrigatoriedade de cada uma das NBCs é colocada pelo CFC por meio de Resoluções específicas desse regulador.

Sobre as ISAs é importante mencionar suas últimas atualizações para se chegar nas normas utilizadas atualmente no Brasil. Em 2004, o IAASB iniciou um programa para melhorar a clareza dos textos das normas e refletir as novas convenções que foram acontecendo ao longo do tempo - Clarity Project. Esse projeto compreendeu as seguintes ações:

- Identificar os objetivos gerais do auditor, quando da realização de uma auditoria de acordo com as ISAs; 
- Definir um objetivo em cada ISA, estabelecendo as obrigações do auditor com relação a esse objetivo;

- Clarificar as imposições aos auditores pelos requisitos das normas de auditoria e a linguagem utilizada para comunicar essas exigências;

- Eliminar qualquer ambiguidade sobre o que é requisitado pelo auditor; e

- Melhorar a compreensibilidade das ISAs por meio de melhoras nas redações dos textos.

Todas as ISAs alteradas entraram em vigor a partir de 15 de dezembro de 2009.

Em paralelo ao Clarity Project, o IAASB sempre teve como umas de suas discussões o relatório do auditor. De acordo com o regulador, o relatório do auditor é um meio essencial para comunicar o resultado de uma auditoria. Existia uma demanda dos usuários desse relatório para que fossem mais informativos no que tange a questões relevantes para os usuários. Para esses usuários, trata-se do meio de influenciar a percepção do valor da auditoria das demonstrações financeiras.

Para atender a essa demanda, o modelo de relatório do auditor foi reformulado, e a principal mudança refere-se à adição de uma seção específica que trata as questões-chave de auditoria (Key-Audit-Matters $)^{17}$. Além da alteração no modelo do relatório, outras normas também foram modificadas para estarem em consonância com essa mudança ${ }^{18}$.

No Brasil, as mesmas alterações foram feitas pelo CFC para atender a essas mudanças, incluindo a criação da NBC TA 701 - Comunicação dos Principais Assuntos de Auditoria no Relatório do Auditor Independente.

No contexto da auditoria das demonstrações financeiras, os objetivos gerais do auditor, de acordo com a NBC TA 200 (CFC, 2009a), são:

Obter segurança razoável de que as demonstrações financeiras como um todo estão livres de distorção relevante, independentemente se causadas por fraude ou erro, possibilitando assim que o auditor expresse sua opinião sobre se as demonstrações financeiras foram elaboradas, em todos os aspectos relevantes, em conformidade com a estrutura de relatório financeiro aplicável; [e]

\footnotetext{
${ }^{17}$ Para esse assunto, foi criado um standard específico: ISA 701 - Communicating Key Audit Matters in the Independent Auditor's Report.

${ }^{18}$ Normas revisadas: ISA 700, ISA 570, ISA 705, ISA 706, ISA 260 e ISA 720.
} 
Apresentar relatório sobre as demonstrações financeiras e comunicar-se, como exigido pelas NBC TAs, em conformidade com as constatações do auditor.

Com relação às responsabilidades, NBC TA 200 deixa claro que uma auditoria, feita com base nas normas de auditoria aplicáveis no Brasil, é conduzida com base na premissa de que a administração e os responsáveis pela governança têm conhecimento de certas responsabilidades que são fundamentais para a condução da auditoria.

A definição dos objetivos do auditor, trazidos por essa norma, aborda uma questão importante para essa pesquisa. O fato de o auditor ter de obter uma segurança razoável de que as demonstrações financeiras como um todo estão livres de distorções relevantes, não significa que o auditor deve ter certeza de que essas demonstrações financeiras estejam livres de distorções relevantes. Essa diferença de entendimento, muitas vezes, leva os usuários das informações financeiras a terem uma percepção e um anseio diferente da realidade do trabalho de auditoria.

De acordo com entrevista feita com o Prof. Dr. Nelson Carvalho:

Auditores independentes de demonstrações contábeis são intermediários informacionais (dentre outros, como analistas e agências de classificação de crédito). Não são "tomadores" ou "compradores" de riscos, como o é uma seguradora em relação aos riscos de seus clientes. Portanto, auditoria ou asseguração só pode ser razoável e não absoluta, por se tratar de serviço (e não de apólice de seguro), realizado de forma racional no sentido de coletar evidências que permitam aumentar a confiança sobre os relatórios financeiros que informam provedores de capital (detentores primários do risco, o "capital de risco") acerca da posição financeira e desempenho da entidade tomadora de recursos, focando-se na aderência.

Com relação aos aspectos de fraude nos trabalhos, a NBC TA 200 deixa claro, com relação à natureza dos procedimentos de auditoria, que uma fraude pode envolver esquemas sofisticados e organizados para a sua ocultação, e que os procedimentos de auditoria relacionados à obtenção de evidências podem ser ineficazes para sua detecção.

A norma ainda estabelece que "o auditor não é treinado nem obrigado a ser especialista na verificação de autenticidade de documentos" e "a auditoria não é uma investigação oficial de um suposto delito. Portanto, o auditor não recebe poderes legais específicos, tais como o poder de busca, que podem ser necessários para tal investigação" (CFC, 2009a, p. 18).

As normas brasileiras de auditoria ainda trazem uma orientação específica acerca das responsabilidades do auditor com relação à fraude, a NBC TA 240 (CFC, 2009b). O normativo 
deixa claro que a principal responsabilidade pela prevenção e detecção da fraude é dos responsáveis pela governança da entidade e da sua administração.

Ainda de acordo com a NBC TA 240, ao fazer menção aos objetivos do auditor descritos na NBC TA 200, ela ainda reforça que, devido a limitações inerentes da auditoria, há um risco inevitável de que algumas distorções relevantes das demonstrações contábeis podem não ser detectadas, apesar de a auditoria ser devidamente planejada e realizada de acordo com as normas de auditoria.

Outros dois aspectos que geram dúvida sobre as responsabilidades do auditor referem-se à continuidade operacional e à responsabilidade com relação às informações financeiras que são divulgadas em conjunto com as demonstrações financeiras.

Sobre o primeiro, a NBC TA 570 determina que a responsabilidade do auditor é obter evidência suficiente sobre a adequação do uso do pressuposto da continuidade operacional na elaboração e consequente divulgação das demonstrações financeiras. Se houver uma incerteza significativa sobre a continuidade da empresa, o auditor deve expressar uma opinião sobre isso (CFC, 2009c).

A responsabilidade sobre a avaliação de continuidade da empresa é da administração. $\mathrm{O}$ auditor deve revisar a avaliação da administração sobre a capacidade de continuidade operacional.

Outra situação que pode gerar dúvida com relação às responsabilidades do auditor refere-se às informações (denominadas como 'outras informações') de documentos que contenham as demonstrações financeiras auditadas, como o caso de relatórios anuais e outros documentos similares.

Sobre isso, a NBC TA 720 estabelece que o auditor deve ler as outras informações para identificar inconsistências relevantes, se houver, com as demonstrações financeiras auditadas. Se nesse processo o auditor identificar inconsistências relevantes, deve discutir o assunto com a administração e, se após essa discussão ainda considerar que existe distorção, que a administração se recusa a corrigir, deve notificar à governança e tomar medidas adicionais apropriadas (CFC, 2009d).

$\mathrm{Na}$ Tabela abaixo, constam, conforme mencionado, algumas das principais normas de auditoria que tratam da responsabilidade do auditor e que, no contexto desta pesquisa, podem suscitar dúvida por parte dos usuários sobre o papel do auditor. 
Tabela 8 - Responsabilidades e objetivos do auditor

\begin{tabular}{l|l}
\hline \multicolumn{1}{c|}{ Norma de Auditoria19 } & \multicolumn{1}{c}{ Responsabilidade do auditor } \\
\hline $\begin{array}{l}\text { NBC TA 200 - Objetivos gerais do } \\
\text { auditor independente e a condução } \\
\text { da auditoria em conformidade com } \\
\text { as normas de auditoria }\end{array}$ & $\begin{array}{l}\text { - Expressar opinião se as demonstrações financeiras foram } \\
\text { elaboradas em todos os aspectos relevantes, em conformidade } \\
\text { com a estrutura de relatório financeiro aplicável. } \\
- \text { Obter segurança razoável de que as demonstrações } \\
\text { financeiras estão livres de distorção relevante. }\end{array}$ \\
\hline $\begin{array}{l}\text { NBC TA 240 - Responsabilidade } \\
\text { do auditor em relação à fraude, no } \\
\text { contexto da auditoria das } \\
\text { demonstrações contábeis }\end{array}$ & $\begin{array}{l}\text { - Responsável por obter segurança razoável de que as } \\
\text { demonstrações financeiras, como um todo, não contêm } \\
\text { distorções relevantes, causadas por fraude ou erro. }\end{array}$ \\
\hline $\begin{array}{l}\text { NBC TA 570 - Continuidade } \\
\text { Operacional }\end{array}$ & $\begin{array}{l}\text { - Obter evidência de auditoria suficiente sobre a adequação do } \\
\text { uso, pela administração, do pressuposto de continuidade } \\
\text { operacional na elaboração e apresentação das demonstrações } \\
\text { financeiras. } \\
\text { - Expressar uma conclusão se existe incerteza significativa } \\
\text { sobre a capacidade de continuidade operacional. }\end{array}$ \\
$\begin{array}{l}\text { - A opinião do auditor não abrange "outras informações", e o } \\
\text { auditor não tem responsabilidade específica por determinar se } \\
\text { essas estão adequadamente apresentadas. Entretanto, o auditor } \\
\text { deve ler as outras informações porque a credibilidade das } \\
\text { demonstrações financeiras pode estar prejudicada por } \\
\text { inconsistências relevantes entre as demonstrações contábeis } \\
\text { auditadas e as "outras informações". }\end{array}$ \\
$\begin{array}{l}\text { informações incluídas em } \\
\text { documentos que contenham } \\
\text { demonstrações contábeis } \\
\text { auditadas. }\end{array}$
\end{tabular}

Fonte: Conselho Federal de Contabilidade - NBC TAs

No Brasil, existe obrigatoriedade regulatória para que as companhias abertas tenham as demonstrações financeiras auditadas. A Lei 6.404, de 1976, em seu artigo 177, parágrafo $3^{\circ}$, alterado pela Lei 11.941 de 2009, estabelece que as demonstrações financeiras das companhias abertas observarão, ainda, as normas expedidas pela Comissão de Valores Mobiliários (CVM) e serão obrigatoriamente submetidas à auditoria independente nela registrados.

A CVM foi criada pela Lei 6.385, de 1976, e tem, como algumas de suas atribuições, o dever de fiscalizar as atividades e os serviços do mercado de valores mobiliários, além de inspecionar as companhias abertas, fazendo-as cumprir as políticas definidas pelo Conselho Monetário Nacional.

Esse regulador, por meio da Instrução CVM 308 de 1999, estabelece os deveres e as responsabilidades dos auditores independentes. De acordo com o artigo 25, no âmbito do mercado de valores mobiliários, o auditor deve verificar:

\footnotetext{
${ }^{19}$ A lista completa das normas que orientam os trabalhos dos auditores independentes está contida nos Apêndices A, B e C.
} 
a) se as demonstrações contábeis e o parecer de auditoria foram divulgados nos jornais em que seja obrigatória a sua publicação e se esses documentos correspondem às demonstrações contábeis auditadas e ao relatório ou parecer originalmente emitido;

b) se as informações e análises contábeis e financeiras apresentadas no relatório da administração da entidade estão em consonância com as demonstrações contábeis auditadas;

c) se as destinações do resultado da entidade estão de acordo com as disposições da lei societária, com o seu estatuto social e com as normas emanadas da CVM; e

d) o eventual descumprimento das disposições legais e regulamentares aplicáveis às atividades da entidade auditada e/ou relativas à sua condição de entidade integrante do mercado de valores mobiliários, que tenham, ou possam vir a ter reflexos relevantes nas demonstrações contábeis ou nas operações da entidade auditada (art. 25, inciso I) (Instrução CVM 308, 1999, p. 10)

O Conselho Monetário Nacional, por meio da Resolução CMN 3.198 de 2004 e da Resolução CNSP 118 de 2004, respectivamente, também determinaram a obrigatoriedade de auditoria independente para as entidades que estão sob sua supervisão.

A Resolução CMN 3.198, em seu artigo 15, inciso IV, ainda menciona que uma das atribuições do Comitê de Auditoria é "avaliar a efetividade das auditorias independentes e interna, inclusive quanto à verificação do cumprimento de dispositivos legais e normativos aplicáveis à instituição, além de regulamentos e códigos internos” (Resolução BCB 3.198, 2004).

Tanto as resoluções da CVM quanto do Bacen abordam aspectos sobre a prestação de serviço do auditor como a questão da substituição periódica do auditor, independência, remessas de informações periódicas e certificações, entre outros. No entanto, os normativos desses reguladores não abordam, especificamente, as responsabilidades do auditor.

Com relação à supervisão do auditor independente, por parte do regulador, a Lei 6.385/76 menciona que o Bacen tem competência para aplicar penalidades às empresas de auditoria no caso de omissões ou outros atos praticados no desempenho de suas funções:

Art. 26. Somente as empresas de auditoria contábil ou auditores contábeis independentes, registrados na Comissão de Valores Mobiliários poderão auditar, para os efeitos desta Lei, as demonstrações financeiras de companhias abertas e das instituições, sociedades ou empresas que integram o sistema de distribuição e intermediação de valores mobiliários.

$\S 1^{\circ}$ - A Comissão estabelecerá as condições para o registro e o seu procedimento, e definirá os casos em que poderá ser recusado, suspenso ou cancelado.

$\S 2^{\circ}$ - As empresas de auditoria contábil ou auditores contábeis independentes responderão, civilmente, pelos prejuízos que causarem a terceiros em virtude de culpa ou dolo no exercício das funções previstas neste artigo.

$\S 3^{\circ}$ Sem prejuízo do disposto no parágrafo precedente, as empresas de auditoria contábil ou os auditores contábeis independentes responderão administrativamente, perante o Banco Central do Brasil, pelos atos praticados ou omissões em que houverem incorrido no desempenho das atividades de auditoria de instituições financeiras e demais instituições autorizadas a funcionar pelo Banco Central do Brasil. 
$\S 4^{\circ} \mathrm{Na}$ hipótese do parágrafo anterior, o Banco Central do Brasil aplicará aos infratores as penalidades previstas no art. 11 desta Lei. (Incluído pela Lei no 9.447, 14.3.1997). (Lei 6.385, 1976)

\subsection{Responsabilidade sobre fraudes}

Uma das questões mais polêmicas com relação ao trabalho do auditor independente está relacionada com a responsabilidade pela detecção de fraude dentro das companhias auditadas. Diante de uma situação de exposição e fragilidade para a companhia, como o caso de uma fraude, surgem os questionamentos e junto com eles a diferença de expectativas com relação às responsabilidades do auditor. Nesse contexto, é importante considerar também o papel do contador/auditor forense.

É importante mencionar a diferença existente entre dois tipos de profissionais que normalmente são citados em casos de questões relacionadas à fraude. Os primeiros profissionais que nos vêm em mente sem dúvida são os auditores independentes. Obviamente são lembrados por estarem dentro das companhias, executando o seu trabalho, com o objetivo de aumentar o grau de confiança nas demonstrações contábeis por parte dos usuários.

É muito comum haver uma confusão a respeito das atribuições do auditor independente dentro das companhias. Seu objetivo, conforme estabelecido pelas normas internacionais de auditoria, é emitir uma opinião de que as demonstrações contábeis foram elaboradas, em todos os aspectos relevantes, de acordo com a estrutura de relatório financeiro aplicável. Isso significa que, no Brasil, por exemplo, a estrutura de relatório financeiro aplicável, no caso de companhias abertas, é estar em conformidade com as normas internacionais de contabilidade - IFRS.

Os auditores devem ter a sensibilidade e empenhar suas atividades para o gerenciamento das expectativas sobre o lucro das companhias e exercitar apropriado nível de ceticismo profissional (Ramamoorti, Morrison III, Koletar, \& Pope, 2013).

É importante mencionar que é incorreta a ideia de que a auditoria independente tem como foco a identificação e prevenção de erros (Gray, 2008). Os erros, sem dúvida, devem ser considerados quando da execução dos trabalhos, mas não são o foco do auditor. O mesmo raciocínio é aplicável com relação à fraude. O auditor deve considerá-la e endereçar procedimentos para que as demonstrações financeiras estejam livres de erros materiais, inclusive oriundos de fraude, desde que relevante no contexto dessas demonstrações financeiras. 
O relatório da ACFE do ano de 2016, que contém um estudo global sobre os casos de fraude, revela que a detecção inicial das fraudes ocupacionais ${ }^{20}$, na maioria das ocorrências, é descoberta por meio de dicas sobre esses atos $(39,1 \%)$. Em segundo lugar está a auditoria interna $(16,5 \%)$. O auditor independente aparece em oitavo lugar, correspondendo a 3,8\% dos casos (Association of Certified Fraud Examiners [ACFE], 2016).

\section{Figura 5 - Detecção inicial de fraudes ocupacionais}

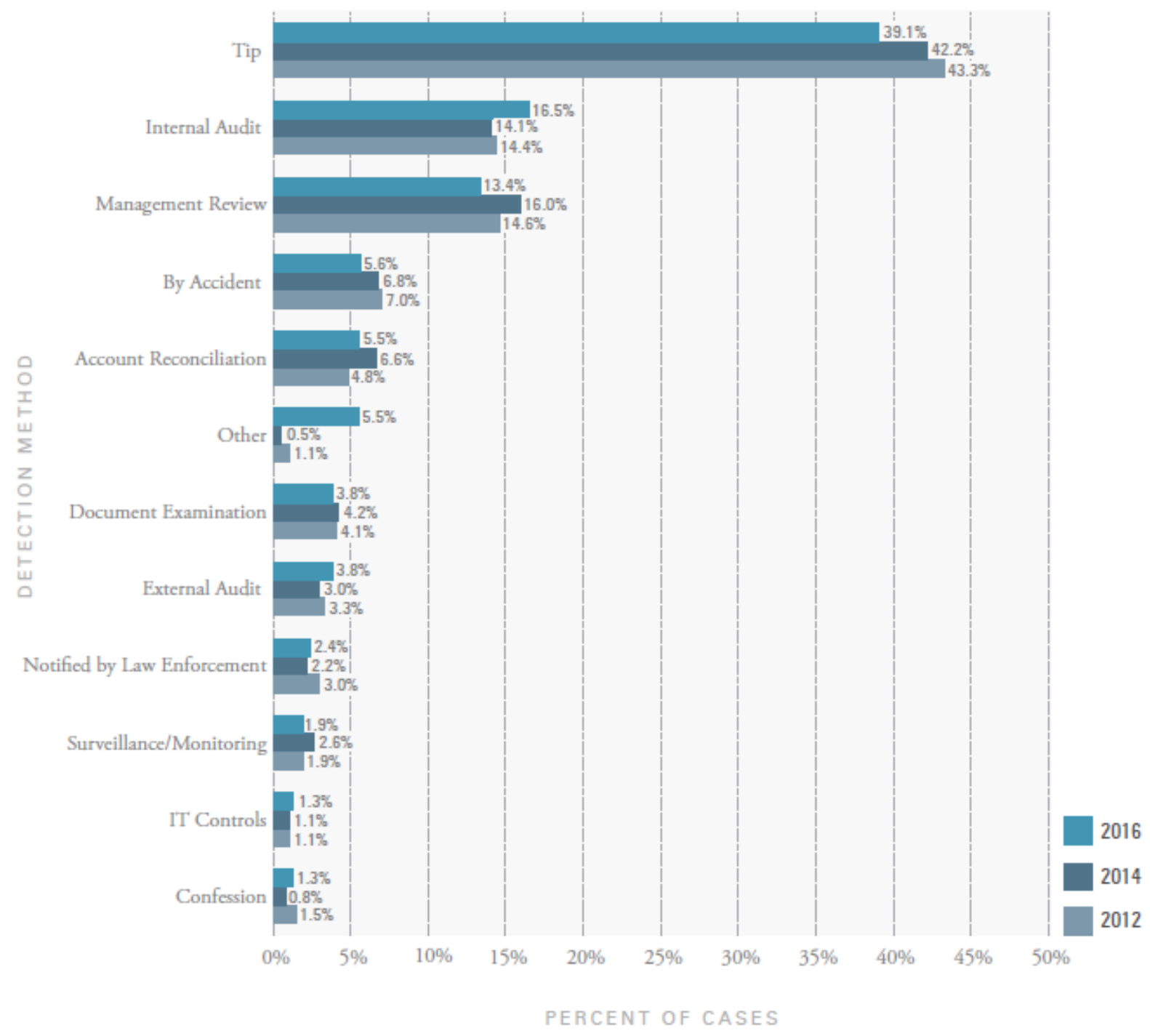

Fonte: ACFE (2016, p. 21)

Mas afinal, quem são os responsáveis pela detecção de fraude dentro das organizações? As normas internacionais de auditoria clarificam que a responsabilidade pela prevenção e detecção

\footnotetext{
${ }^{20}$ De acordo com o respectivo relatório, trata-se do uso de uma ocupação para enriquecimento pessoal por meio do uso deliberado ou má aplicação de recursos ou bens da organização empregadora.
} 
de fraude é dos responsáveis pela governança da entidade e da sua administração. Essa, por sua vez, pode contratar especialistas em detecção de fraudes ou "crimes do colarinho branco", que são os contadores ou auditores forenses.

A estatística do relatório da ACFE (Figura 1) corrobora com o fato de que a auditoria independente não é o foco primário de detecção de fraudes e cabe à administração das empresas avaliarem suas melhores formas de gestão de risco contra esse tipo de atividade.

Sobre o papel do auditor forense, de acordo com Fenton e Isaacs (2012), para atuar como esses profissionais, são necessárias diversas habilidades como contabilidade gerencial, auditoria, impostos e negócios de forma geral. Os autores ainda destacam a criatividade necessária para combinar todas essas habilidades para oferecer resultados que suportem exames minuciosos presentes no ambiente de litígios. Esses serviços devem ser, acima de tudo, lógicos, convincentes e compreensíveis. Se o contador forense não convencer o juiz ou o júri de que o produto do seu trabalho contém essas características, seus trabalhos não terão credibilidade e, consequentemente, darão menos valor aos seus esforços.

As investigações de contabilidade forense incluem serviços de contencioso relacionados a diversas situações incluindo: compras de negócios, avaliação de ativos, danos em propriedades, perdas devido a desfalques e outros atos ilegais, evasão fiscal e esquemas de lavagem de dinheiro (Gray, 2008).

Christensen, Byington e Blalock (2005) discutem sobre a profissão do contador forense, comparando-a com o auditor independente. De acordo com os autores, a Sarbanes Oxley Act de 2002 colocou mais pressão sobre o auditor independente com relação à responsabilidade de detecção de fraude e de erros materiais no contexto das descontrações financeiras.

As discussões relacionadas a isso são pautadas em argumentos como os objetivos do trabalho da auditoria, a habilidade do auditor independente na detecção de fraude, tempo do trabalho de auditoria e entre outros fatores que impactam a discussão de custo-benefício do trabalho da auditoria.

Considerando esse contexto, foi crescendo no mercado a figura do contador ou auditor forense, profissional com sólida experiência na detecção de fraude e de crimes do colarinho branco.

Segundo os autores, a diferença relacionada às atribuições dos profissionais é clara em seus próprios objetivos. $\mathrm{O}$ auditor independente deve certificar-se que as demonstrações financeiras 
estão livres de erros materiais, e o erro relaciona-se a um ato não intencional. Já o contador forense se insere no ambiente de identificação e fraude, essa que se trata de um ato intencional por parte de seu autor. Nesse contexto, a ótica do auditor é limitada pelo potencial impacto que a fraude pode ter nas demonstrações financeiras.

O envolvimento de um contador forense é importante, pois se trata de um profissional especializado, que possui habilidades de natureza qualitativa e quantitativa para detecção de fraude. As características quantitativas referem-se a ter robusto conhecimento na pesquisa de números para descobrir fraudes, e as características qualitativas incluem ser capaz de determinar como os controles internos podem ser burlados para que sejam cometidos atos ilegais (Christensen, Byington, \& Blalock, 2005).

Sob a ótica do regulador, de acordo com o PCAOB, o auditor forense pode examinar o relatório financeiro e avaliar os controles internos da entidade, no entanto seu objetivo não é expressar uma opinião com base em um conjunto de normas, como no caso do auditor independente. Em vez disso, os usuários dos trabalhos dos auditores forenses estabelecem os seus objetivos de acordo com cada caso. Sugere-se que o trabalho do auditor forense possa ser integrado ao trabalho da auditoria regular das companhias (Public Company Accounting Oversight Board PCAOB [PCAOB], 2007).

No âmbito de trabalhos relacionados à fraude, Crumbley, Heitger e Smith (2013, p. 1001) trazem uma contribuição importante, que é a diferenciação do contador forense e de um auditor que trabalha com investigação de fraude. Segundo os autores, o investigador de fraudes é um contador com habilidades em auditoria, que normalmente se relaciona com o trabalho de auditoria independente, direcionado para o descobrimento, documentação e prevenção de fraude. Já o contador forense pode ser um auditor voltado para trabalhos de fraude, no entanto, esse profissional utiliza outras habilidades como contabilidade, consultoria e direito em trabalhos mais amplos.

Os autores ainda vão além com relação ao trabalho do auditor forense. Eles mencionam que a auditoria forense geralmente é diferente de uma típica auditoria financeira. Essa última é geralmente feita por amostragem e, portanto, não analisa todas as transações dentro de uma empresa. Nesse caso, os sistemas podem ser burlados pois os funcionários das empresas auditadas sabem sobre a atuação da auditoria. Por outro lado, o profissional forense analisa nos detalhes os aspectos específicos de registros, atentando para sua consistência. Naturalmente, 
para se chegar ao nível de detalhe desejado, o trabalho consome mais horas e, consequentemente, é mais caro do que uma auditoria financeira.

Em trabalho anterior, os mesmos autores, Smith e Crumbley (CFD, 2009), trouxeram, de forma resumida, as principais diferenças entre os trabalhos de auditoria, investigação de fraude e contabilidade/auditoria forense:

Tabela 9 - Diferenças entre auditoria, investigação de fraude e auditoria forense

\begin{tabular}{|c|c|c|c|}
\hline Características & Auditoria & Investigação de Fraude & Auditoria Forense \\
\hline $\begin{array}{l}\text { Perspectiva de } \\
\text { tempo }\end{array}$ & Histórica & Histórica & Futura e Histórica \\
\hline Foco primário & Periódico & Reativo & Proativo e contínuo \\
\hline $\begin{array}{l}\text { Escopo da } \\
\text { investigação }\end{array}$ & Estreito & Estreito & Amplo \\
\hline $\begin{array}{l}\text { Principal produto } \\
\text { do trabalho }\end{array}$ & Opinião de auditoria & Relatório do caso de fraude & $\begin{array}{l}\text { Relatório de } \\
\text { Auditoria Forense }\end{array}$ \\
\hline $\begin{array}{l}\text { Principal } \\
\text { responsabilidade }\end{array}$ & Companhias e público & Parte defraudada & $\begin{array}{l}\text { Principal interessado } \\
\text { ou terceira parte }\end{array}$ \\
\hline Orientações & Baseado em regras & $\begin{array}{l}\text { Baseado em princípios. Se } \\
\text { sob as regras de auditoria, } \\
\text { baseado em regras }\end{array}$ & $\begin{array}{l}\text { Baseado em } \\
\text { princípios }\end{array}$ \\
\hline $\begin{array}{l}\text { Propósito do } \\
\text { relatório }\end{array}$ & $\begin{array}{l}\text { Garantir que as normas } \\
\text { contábeis estão sendo } \\
\text { cumpridas }\end{array}$ & Identificar o autor da fraude & $\begin{array}{l}\text { Avaliação de risco de } \\
\text { fraude e serviços } \\
\text { estratégicos }\end{array}$ \\
\hline $\begin{array}{l}\text { Posicionamento } \\
\text { profissional }\end{array}$ & Não acusatório & Acusatório & $\begin{array}{l}\text { Acusatório e não } \\
\text { acusatório }\end{array}$ \\
\hline
\end{tabular}

Fonte: Adaptada (CFD, 2009, p. 69)

Os investigadores de fraude estão preocupados na identificação do autor e coautores/conspiradores que se beneficiaram de atividade fraudulenta já ocorrida. A análise forense, por outro lado, é um processo contínuo que se utiliza de tecnologia para identificar atividades suspeitas ocorridas dentro da companhia ou em um ambiente estipulado. Considerase também o envolvimento dos auditores forenses na prevenção e identificação de fraude, mas geralmente estão envolvidos em trabalhos mais amplos de avaliação de risco.

Uma investigação forense pode ser reativa e proativa. Uma investigação reativa ocorre quando há alguma razão para se suspeitar de fraude ou de uma perda significativa que possa ter uma possibilidade de ser uma fraude. Já a abordagem preventiva envolve a revisão de controles internos e a identificação de áreas mais suscetíveis à fraude (Crumbley \& Apostolou, 2005). 
De forma análoga à ideia de investigação reativa e preventiva de Smith e Crumbley (CFD, 2009), Crumbley e Apostolou (2005) também exploraram essa diferença, no entanto atribuindoas a trabalhos com objetivos diferentes: investigação de fraude e auditor forense.

Ainda com relação às diferenças de expectativas ao trabalho do auditor independente, uma pesquisa efetuada pelo Global Public Policy Symposium também menciona a existência de uma significativa diferença, por parte dos participantes do mercado, no que tange à detecção de fraude. Ainda menciona que é necessário muito diálogo entre os investidores, companhias, stakeholders, normatizadores e profissionais de auditoria sobre que deve ser feito para diminuir essa diferença de expectativas. Menciona-se ainda as seguintes ideias para a detecção de fraude dentro das companhias, relacionadas ao trabalho do auditor forense:

- Auditoria forense regularmente dentro das companhias - sugestão mais agressiva e de maior custo para empresas de capital aberto.

- Auditoria forense de forma aleatória: opção menos onerosa, também para companhias abertas.

- Outras opções baseadas em escolhas: possibilidade de que os acionistas decidam a intensidade dos trabalhos de detecção de fraudes (Global Public Symposium, 2006).

Fica evidente, portanto, que o envolvimento de um profissional contador forense em conjunto com a auditoria traz muitos benefícios não apenas para a companhia analisada e os contadores forenses, mas também para o trabalho da auditoria e para o mercado de uma forma geral.

\subsection{As firmas de auditoria no Brasil}

Com relação ao mercado de auditoria no Brasil, de acordo com pesquisa do Banco Mundial (World Bank, 2013), há quatro grandes firmas internacionais de auditoria que dominam o mercado de prestação de serviços de auditoria a empresas cotadas, bancos e companhias de seguros, impactando positivamente o cumprimento das IFRS.

Além do impacto positivo com relação à adoção das normas internacionais de contabilidade, essas firmas também influenciam os procedimentos de auditoria.

As firmas de auditoria internacionais, por terem sólida tradição, levam vantagem com relação às firmas nacionais, principalmente em termos de procedimentos de auditoria e estrutura. 
Importante mencionar que as grandes subsidiárias de multinacionais são auditadas pelas firmas maiores e sem dúvida há influência sobre os procedimentos adotados pelas empresas de auditoria de menor porte. A estrutura das Big $\mathrm{N}$ também influencia os legisladores, dado que profissionais que pertenceram a essas firmas de auditoria puderam participar na elaboração de diretrizes contábeis governamentais (Iudícibus, 2009).

A função da auditoria, portanto, absorve muitos profissionais de contabilidade e é de muita relevância não apenas para a classe contábil, mas também para o mercado financeiro e de capitais. A Tabela abaixo demonstra o número aproximado de profissionais empregados pelas quatro maiores firmas globais de auditoria, denominadas Big4:

Tabela 10 - Colaboradores de empresas de auditoria

\begin{tabular}{l|c|c}
\hline Empresa & Sigla & $\begin{array}{c}\text { Número de Colaboradores } \\
\text { no Brasil }\end{array}$ \\
\hline KPMG Auditores Independentes & KPMG & 3.504 \\
\hline Ernst \& Young Auditores Independentes & EY & 4.653 \\
\hline Pricewaterhousecoopers Auditores Independentes & PwC & 5.300 \\
\hline Deloitte Touche Tohmatsu Auditores Independentes & DTT & 5.500 \\
\hline
\end{tabular}

Fonte: Elaborada por esta autora

Para o propósito desta pesquisa, serão consideradas no escopo das análises as empresas denominadas Big4, incluindo a representatividade das quatro maiores empresas de auditoria que atuam no Brasil e a representatividade de empresas relevantes para o mercado financeiro e de capitais que tem essas firmas como prestadoras de serviços de auditoria.

Na Tabela abaixo pode-se verificar que as Big4 são responsáveis por $67 \%$ do mercado de companhias abertas que estão sob a autarquia da CVM.

\footnotetext{
${ }^{21}$ As informações da KPMG e da EY foram obtidas nos Relatórios de Sustentabilidade dos anos de 2014 (KPMG Brasil, 2014) e 2013 (EY Brasil, 2013), respectivamente. As informações da PwC e da Deloitte foram obtidas no website dessas empresas (http://www.pwc.com.br e http://www2.deloitte.com/br/pt.html, respectivamente).
} 
Tabela 11 - Empresas de auditoria

\begin{tabular}{l|c|c}
\hline Empresas de Auditoria & $\begin{array}{c}\text { Quantidade } \\
\text { Empresas }^{22}\end{array}$ & Representatividade \\
\hline Deloitte Touche Tohmatsu Auditores Independentes & 105 & $17 \%$ \\
\hline Ernst \& Young Auditores Independentes & 92 & $15 \%$ \\
\hline KPMG Auditores Independentes & 116 & $19 \%$ \\
\hline Pricewaterhousecoopers Auditores Independentes & 101 & $16 \%$ \\
\hline OUTRAS & 208 & $33 \%$ \\
\hline TOTAL & $\mathbf{6 2 2}$ & \\
\hline
\end{tabular}

Fonte: http://sistemas.cvm.gov.br

As demais firmas de auditoria, que possuem autorização da CVM para atuação no mercado de capitais brasileiro, detêm aproximadamente 33\% do mercado de companhias abertas e são compostas por 76 firmas.

\subsection{Audit Expectation Gap (AEG)}

O AEG nada mais é do que a diferença de expectativas com relação ao trabalho do auditor, por parte dos usuários do relatório do auditor. Pode ocorrer, por exemplo, que determinado investidor tenha a expectativa de que o auditor tenha executado determinado trabalho, quando, na verdade, essa atividade não é uma atribuição dele.

Se as responsabilidades dos auditores não forem claras para seus usuários, provavelmente haverá uma diferença entre a expectativa do usuário e o que está sendo oferecido a ele.

Lowe (1994) define AEG como a diferença entre o que público espera da atividade de auditoria e o que esses profissionais realmente proporcionam. Sikka, Puxty, Willmott e Cooper (1998) definem AEG como a representação da discrepância entre o que o público espera de uma auditoria e o que os profissionais de auditoria objetivam ser. McEnroe e Martens (2001) se referem ao AEG como a diferença entre o que os usuários das demonstrações financeiras reconhecem como sendo parte das responsabilidades dos auditores e o que os auditores consideram o que envolve suas responsabilidades. Nota-se, com base nas definições citadas, que elas podem ser consideradas as definições mais abrangentes do AEG. Tratam de forma abrangente da diferença de expectativa com relação ao trabalho do auditor independente.

\footnotetext{
${ }^{22}$ Para essa compilação de dados foram consideradas as companhias abertas com cadastro ativo. Não foram consideradas companhias estrangeiras e fundos de investimentos. Informações obtidas no website da CVM.
} 
Eden (2003) menciona que por volta da década de 1980 a classe contábil passou a definir o AEG. Segundo o autor, enquanto os investidores esperam que os contadores descubram imediatamente os delitos dentro das empresas auditadas e avaliem o desempenho da sua gestão, a função real do contador é auditar os livros e avaliar a adequação e a veracidade dos relatórios financeiros. A explicação de Eden (2003) já traz mais elementos para a definição, que se relacionam com a expectativa de que se realizem determinadas atividades e funções que de fato podem divergir das reais atribuições desses profissionais.

A tese de Porter (1990) é considerada um dos trabalhos mais importantes no que se refere à definição de AEG. No artigo que tem como base a sua tese (Porter, 1993), a autora tenta detalhar mais o AEG, menciona que ele pode ser subdividido em dois componentes: (i) ' $g a p$ de desempenho' e (ii) gap de razoabilidade'. Especificamente sobre o componente relacionado ao desempenho, com base na estrutura proposta pela própria autora, o AEG pode ser definido como a diferença entre as expectativas da sociedade sobre os auditores e o desempenho dos auditores percebidos pela sociedade. Já o gap de razoabilidade, também proposto pela autora, trata da diferença sobre o que a sociedade espera que os auditores façam em contraposição às atribuições percebidas pelos próprios profissionais.

Com base nessa definição, percebe-se que a componentização do AEG auxilia no entendimento desse problema e, consequentemente, pode trazer contribuições significativas para as tentativas de diminuição e resolução dessa questão.

$\mathrm{O} \mathrm{IAASB}^{23}$ (2011) define o AEG como a diferença entre o que os usuários esperam do auditor e da auditoria das demonstrações financeiras e a realidade do que uma auditoria é. $\mathrm{O}$ normatizador também menciona que é sugerido que essa diferença de expectativa resulte, em parte, da maneira pela qual o auditor comunica seus achados para os usuários das demonstrações financeiras ${ }^{24}$ (tradução livre desta autora).

Sobre os impactos da existência do AEG, o Prof. Dr. Nelson Carvalho menciona que "essa lacuna em si gera ineficiências, pois dentro de um fluxo de comunicação tão relevante, que

\footnotetext{
${ }^{23}$ International Auditing and Assurance Standards Board.

24 "In the broadest terms, the expectations gap is the difference between what users expect from the auditor and the financial statement audit, and the reality of what an audit is.

"It also has been suggested that the expectations gap results, in part, from the manner in which auditors communicate their findings to users of financial statements."
} 
influencia e subsidia tomada de decisão econômica, a existência de lacuna e de "ruído" está longe de ser desejável por deteriorar a confiança na função da auditoria”.

Dennis (2010) realizou uma investigação conceitual para a ideia de AEG. Ele destaca que é necessário haver mais clareza na discussão sobre as questões relacionadas às expectativas do papel do auditor. Isso pode trazer argumentos com mais significado sobre o motivo da expectativa criada pelos usuários do relatório do auditor.

O autor ainda argumenta que o termo AEG por vezes é mal definido e pode assumir diversas facetas quando se analisa a relação dos auditores com outros grupos. Se a expressão é mal utilizada, a comunicação e o debate se tornam indeterminados. A expressão pode se tornar vaga e pode gerar desentendimentos quanto ao seu correto uso na prática. Reconfigurar o AEG é um meio de identificar as razões das crenças e dos desejos para tornar claro como esses gaps podem ser construídos. As razões para as crenças são diferentes das razões para os desejos, e esses são entendidos por tipos de razões diferentes.

Se as crenças são baseadas na ignorância, então, a solução seria educar as partes que têm esse erro na crença. Essa é frequentemente a responsável pelas questões que envolvem AEG. Se as expectativas são desejos, então os gaps precisam ser examinados considerando o raciocínio prático dos objetivos para esses desejos.

Para Boyle e Canning (2005), o gap significa a divergência entre as expectativas da sociedade, com relação ao papel do auditor e a crença da atividade do auditor do que pode razoavelmente ser esperado para se alcançar.

É importante retomar o trabalho de Porter (1990), que teve como principal objetivo em seu trabalho analisar o gap entre as expectativas da sociedade com relação auditores externos e o desempenho desses profissionais. Posteriormente, considerando essas análises, definiu uma teoria que explica o papel do auditor externo na Nova Zelândia.

A autora definiu que o AEG é composto por dois grandes componentes: (i) gap de razoabilidade e (ii) gap de desempenho. O último pode ainda ser dividido em: (a) padrões deficientes e (b) desempenho deficiente. A pesquisa empírica realizada neste trabalho forneceu um forte suporte para desenhar essa estrutura.

Sobre os componentes do AEG, Porter (1990) define: 
- Gap de desempenho deficiente: diferenças de expectativas com relação ao desempenho do auditor independente com base nas suas obrigações e o desempenho percebido pelos demandantes de seu trabalho. Com base na sua pesquisa, trata-se do menor componente do AEG e é o mais fácil de se controlar e endereçar soluções. No que diz respeito à percepção dos auditores sobre as obrigações que são atribuídas a eles, mas que esses não têm ciência delas, a autora sugere conspropostatantes treinamentos para os profissionais, antes e depois de ingressarem nessa atividade.

Vale destacar que duas responsabilidades do auditor são percebidas com baixo desempenho que são: divulgação de problemas de continuidade da companhia auditada e divulgação de distorções das informações financeiras. A demanda no caso dos pesquisados foi por relatórios mais francos e diretos sobre a principais preocupações dos auditores com relação ao futuro das empresas auditadas. Isso inclui também trazer mais informações para os usuários, de forma compreensiva ('user friendly'). De certa forma, essas questões sempre foram debatidas pelos próprios reguladores da atividade e o novo formato do relatório do auditor tem por objetivo suprir essas necessidades e, consequentemente, contribuir para a diminuição do AEG.

- Gap de padrões deficientes: essa diferença de expectativas está relacionada com a percepção de que o auditor é responsável por determinada atividade que ele de fato não é, considerando que não consta essa obrigação nas normas e padrões de auditoria. Segundo a autora, esse é o componente nos quais os profissionais teriam mais dificuldade de endereçar, sem a assistência de outras partes. Os elementos de maior destaque referem-se à expectativa que se tem de que os auditores reportem qualquer tipo de irregularidade para as autoridades locais e à divulgação da percepção dos auditores sobre os controles internos das empresas, que incluem as suas deficiências.

Segundo a avaliação de Porter (1990), o endereçamento desses itens que compõem esse gap não traria custos tão altos para os auditores. Além disso, com relação aos aspectos de controles internos, já faz parte do trabalho do auditor avaliar e formalizar esses aspectos durante o seu trabalho. Isso inclusive é formalmente enviado para a administração das companhias auditadas, indicando, quando aplicável, os principais pontos de deficiência de controles internos. Organizar isso de forma que seja divulgado para os usuários das demonstrações financeiras não traria significativos custos adicionais uma vez que o trabalho já é efetuado no curso normal da auditoria. 
- Gap de razoabilidade: trata-se das diferenças de expectativas nas quais os usuários acham que os auditores devem executar determinada tarefa ou atividade que não é esperada que os auditores as façam. Um exemplo é a expectativa que os usuários têm de que os auditores examinem e opinem sobre a razoabilidade dos orçamentos e previsões da administração, incluídas nos relatórios anuais, quando isso não é compatível com o papel desses profissionais. Outras atividades também foram relatadas como esperadas por serem executadas pelos auditores independentes, como:

- Garantir que as demonstrações financeiras têm acurácia;

- Garantir que a companhia é solvente;

- Detectar e informar atos ilícitos que não estejam relacionados com a contabilidade da companhia; e

- Avaliar a eficiência e efetividade da administração da companhia auditada, entre outros.

Sem dúvida, esse tipo de expectativa está relacionado com a falta de conhecimento e entendimento do trabalho e das funções do auditor independente. Segundo Porter (1990), para se diminuir essa lacuna, é necessário o foco na educação e comunicação. A dificuldade reside no fato de que se tratam de grupos de profissionais diversos o que dificultaria a implementação de um plano de ação eficiente. No entanto, a comunicação também aparece como um elementochave na tentativa de resolução ou diminuição do problema. Trazer mais informações para a comunidade financeira e melhorar a comunicação do auditor, por meio do relatório de auditoria, surgem novamente como potenciais soluções para o problema. 
Figura 6 - Estrutura do audit expectation-performance gap

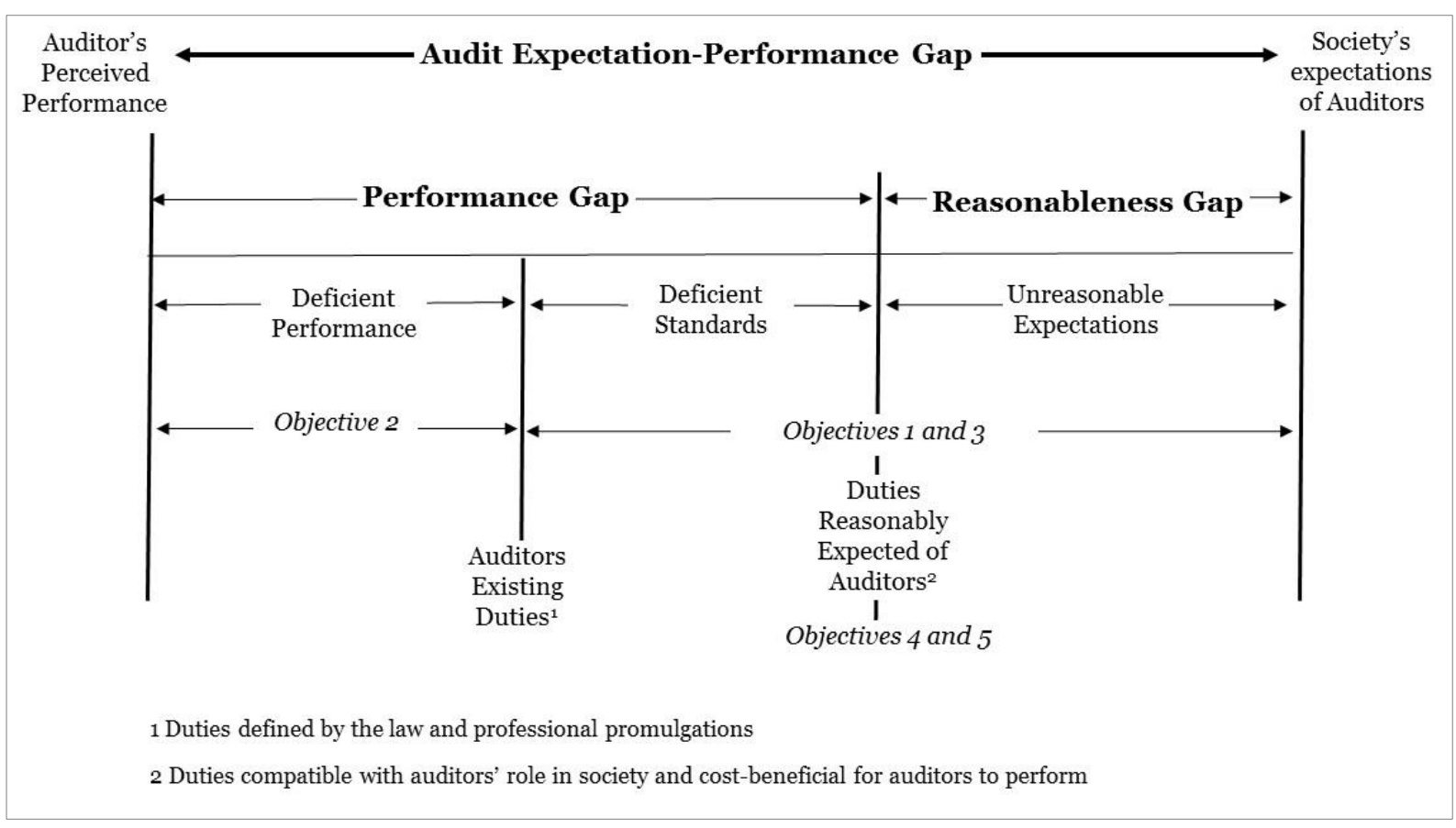

Fonte: Porter, 1990, p. 14

Sobre a metodologia do trabalho, a autora enviou 1.700 questionários de forma randômica para membros de grupos selecionados na Nova Zelândia, que são afetados de alguma forma pelo relatório do auditor. Os resultados indicaram que aproximadamente 50\% do gap podem ser atribuídos à deficiência nas normas, $34 \%$ atribuídos aos resultados irracionais sobre os auditores (gap de razoabilidade) e 16\% derivados da percepção de que o desempenho dos auditores está abaixo do estabelecido pelas normas.

Para se obter a definição e a extensão propostos no objetivo de seu trabalho, Porter (1990) levou em consideração os seguintes grupos que demandam ou têm interesse no trabalho do auditor independente (chamados de role senders): auditados (gerentes corporativos, diretores e comitês de auditoria) e reguladores (governos, tribunais, bolsas de valores), esses dois considerados como fortes demandantes dessa atividade. Além deles, os beneficiários da auditoria, que são parte da comunidade financeira (investidores, analistas, corretores), acadêmicos, credores empregados e clientes das empresas, bem como o público em geral.

O trabalho de Porter (1990) é considerado de grande importância, pois contribuiu com novas ideias com relação à composição, estrutura e extensão do AEG. A metodologia desenvolvida foi utilizada posteriormente por diversos autores na tentativa de mensuração do AEG em diversas jurisdições. A pesquisa indicou que, uma vez que a discrepância entre as expectativas 
da sociedade e o desempenho percebido pelos próprios auditores é detectada, o dever em questão pode ser analisado para identificar qual componente do gap ele representa. Se o dever é associado a um componente específico do gap, ações corretivas apropriadas podem ser tomadas.

Em trabalho posterior, com relação ao gap de desempenho, a autora sugeriu as seguintes medidas na tentativa de reduzi-lo (Porter, Ó hÓgartaigh, \& Baskerville, 2012b, p. 236):

(i) Assegurar que novas questões na área de auditoria são amplamente discutidas, e a sociedade se torne consciente do que é e não é factível e viável para os auditores realizarem;

(ii) Contemplar, nas normas de auditoria, as responsabilidades do auditor esperadas pela sociedade, respeitando-se a relação de custo-benefício na execução desses trabalhos;

(iii) Assegurar que as normas de auditoria especifiquem o que é requerido pelos auditores, além do monitoramento do seu desempenho, para se certificar de que estão cumprindo seu papel.

Para Sikka et al. (1998), a atividade do auditor veio se desenvolvendo ao longo dos anos, e o papel de detecção de fraude foi se tornando secundário no que tange aos objetivos desse profissional. No entanto, o senso comum, construído originalmente com base nas demandas pelos serviços de auditoria, não excluiu isso da consciência do público. Reguladores, políticos, juízes, júris e jornalistas financeiros têm ignorado ou resistido ao fato da detecção de fraude como sendo um dos objetivos do auditor.

Pressões para refinar ou revisar o significado da auditoria estão intimamente relacionadas com os desenvolvimentos sociais, econômicos e políticos de sua época. Em uma sociedade marcada por estruturas institucionais contraditórias e uma distribuição de poderes desigual, riquezas e influências, as práticas sociais são instáveis inerentemente, e o significado da auditoria está sujeito à negociação e transformação. Ainda segundo os autores, a autorregulação dessa atividade não pode deixar de levar em consideração os anseios dos usuários das demonstrações financeiras.

Bedard, Sutton, Arnold e Phillips (2012) procuraram estender as pesquisas relacionadas ao AEG, estudando quando os investidores entendem que as informações que não estão contidas nas demonstrações financeiras, como no caso do $10-\mathrm{K}^{25}$, bem como nos websites corporativos das entidades não são auditadas. Os pesquisadores enviaram questionários para investidores profissionais e não profissionais para que eles identificassem corretamente quais os componentes do 10-K são auditados. No entanto, os investidores dos dois grupos acreditam que

\footnotetext{
${ }^{25}$ Trata-se de um relatório anual, exigido pela SEC, que apresenta um sumário do desempenho da companhia.
} 
as informações, que estão fora das demonstrações financeiras, são auditadas, quando de fato não são.

Os autores ainda verificaram que, na tomada de decisão, esses usuários utilizam mais as informações que acreditam ser auditadas. Esses resultados suportam a proposta dos auditores por melhores esclarecimentos para os usuários com relação à natureza dos procedimentos por eles efetuados, sobre as informações que não estejam contidas nas demonstrações financeiras.

Arrington, Hillison e Williams (1983) utilizaram a attribution theory para estudar a lacuna de expectativas existente no tocante à relação entre o público e os auditores. A attribution theory prevê a maneira pela qual as pessoas vão processar certos tipos de informação para avaliar a força efetiva de um determinado ator para produzir um resultado. A contribuição dos autores refere-se ao fato de que os contadores podem se beneficiar do entendimento do processo psicológico no auxílio do entendimento das lacunas de expectativas existentes com relação às responsabilidades do trabalho do auditor.

Os autores trouxeram, ainda, as seguintes contribuições com relação a esse tema:

- Os contadores ${ }^{26}$ tendem a atribuir menos responsabilidade pelas falhas do auditor do que os não contadores;

- O processo de integração da informação ${ }^{27}$ influencia o nível de responsabilidade que os outros irão atribuir ao auditor pelo resultado de seus trabalhos;

- Informações acerca do cumprimento das normas de auditoria são mais importantes para os contadores do que para os não contadores; e

- O auditor deve reconsiderar a extrema ênfase no cumprimento das normas de suas atividades e redirecionar os esforços para outros padrões relacionados, por exemplo, ao zelo e à formação profissional.

No Brasil, Menezes (2012) investigou a existência do AEG especificamente em situações relacionadas à prevenção e à detecção de fraudes. A amostra utilizada compreendeu 93 alunos

\footnotetext{
${ }^{26}$ CPAs

${ }^{27}$ Inclui os conceitos de informação consensual, consistente e distintiva. No caso da informação consensual, o julgamento do indivíduo sobre o comportamento do ator (no caso o auditor) corresponde ao comportamento de outros atores em situações similares. No caso da informação consistente, essa refere-se a situações nas quais o auditor tem um histórico de sucesso ou fracasso em determinadas tarefas e cria-se uma expectativa com base nesse histórico. Já a informação distintiva prevê que as falhas podem acontecer em tarefas específicas, considerando, portanto, as dificuldades inerentes a essas tarefas.
} 
de pós-graduação de duas instituições de ensino e 71 auditores de uma firma de auditoria. Os resultados da pesquisa indicaram que ainda que os usuários das informações contábeis percebam de forma positiva as premissas das normas, há diferenças com relação às expectativas.

Albuquerque et al. (2010) tiveram como objetivo identificar o AEG tomando como referência a teoria da legitimidade. Utilizaram, como amostra, questionários respondidos por 50 auditores e 106 usuários da contabilidade. Os resultados indicaram que, tanto os auditores, quanto os demais usuários da contabilidade, apresentaram diferenças de expectativas significativas no tocante à responsabilidade do auditor independente na detecção e na prevenção de fraude.

O AEG é um assunto amplamente discutido e vem acompanhando os desenvolvimentos relacionados à atividade do auditor. Sua existência pode trazer impactos negativos não apenas para o auditor, mas para o mercado de uma forma geral.

Para Carvalho (1989), essa divergência de expectativa merece ações de ambos os lados para ser eliminada ou reduzida e, do lado dos auditores, o primeiro passo parece ser o de se comunicar bem.

\subsection{Evidências Internacionais sobre o AEG}

O AEG vem sendo discutido em diversos países, e a identificação de sua existência foi responsável, por exemplo, pela revisão de determinadas normas de auditoria. Um dos temas que esteve e ainda está em discussão, relacionados ao AEG, é o do relatório do auditor e a suficiência de informação e as formas de abordagem dessa comunicação.

No entanto, os estudos não tiveram apenas esse objetivo. Em diversos países, uma das maiores preocupações foi identificar a existência do AEG. O trabalho de Porter (1993) foi um dos mais relevantes, pois além de discutir conceitualmente os tipos de AEG, a metodologia empregada em seu trabalho serviu como base para diversos outros autores a utilizarem em seus países.

Sidani (2007), por exemplo, avaliou a possível existência do AEG entre o grupo de contadores e não contadores no Líbano. Sua análise sustenta o fato de que o AEG existe entre o que os auditores fazem ou têm a percepção de que estão fazendo, comparado com a percepção dos usuários das demonstrações financeiras. 
O interessante no estudo, no entanto, deve-se ao fato de que ambos os grupos analisados não têm uma forte imagem da atividade, especialmente quando se compara com as práticas de auditoria pelo mundo ou mesmo com relação às suas qualificações técnicas.

O autor conclui, portanto, que há um significativo gap de razoabilidade no Líbano, porém não concluiu que as diferenças de percepção poderiam ser atribuídas a deficiências nos padrões/ normas de auditoria ou mesmo relacionados a desempenho. A peculiaridade do país em estudo deve-se ao fato de que os auditores são apontados, em muitos casos, para cumprir com requerimentos legais e não porque as pessoas compreendem sua função relacionada ao desenvolvimento corporativo e à transparência no mercado. A atividade do auditor e do contador, no Líbano, é vista como especialistas focados em tributos.

Alleyne e Howard (2005) investigaram como os usuários e os auditores percebem as responsabilidades dos auditores relacionadas ao descobrimento de fraudes, a natureza e extensão de fraudes em Barbados e os procedimentos de auditoria utilizados desde o caso da Enron.

Por meio de questionários, os autores encontraram evidências de que há um amplo AEG, uma vez que os auditores sentem que a detecção de fraude é de responsabilidade da administração, enquanto os usuários e a administração discordam. Os autores ainda argumentam que a fraude não é uma grande questão em Barbados, e as companhias que têm auditoria interna, controles internos e comitê de auditoria lidam melhor no tocante à prevenção e à detecção de fraude.

Sobre Singapura, De Martini, Aw e Kim (2000) investigaram a extensão em que as características pessoais estão relacionadas com o AEG. A pesquisa foi feita com auditores, preparadores e usuários das demonstrações financeiras. Os resultados indicaram que o gap prevalece onde os respondentes têm menor experiência de trabalho ou não têm qualificação universitária. Não há evidências de que o gap seja afetado por fatores legais, políticos, sociais ou econômicos.

Os autores ainda concluem que os auditores devem ser mais proativos e tomar as seguintes medidas:

(i) continuar com a responsabilidade de educar o público sobre as funções, objetivo e limitações da atividade de auditoria; 
(ii) considerar que as responsabilidades dos auditores estão relacionadas com as expectativas do público, principalmente quando se trata de questões relacionadas à fraude e;

(iii) garantir a existência contínua do monitoramento da qualidade da auditoria.

Ainda sobre Singapura, Best, Buckby e Tan (2001), ao investigar o AEG, eles também concluíram sobre sua existência, mostrando-se mais significativo com relação à prevenção e à detecção de fraude. Esses achados representam uma questão séria, pois indicam que um considerável valor oriundo do processo de auditoria das demonstrações financeiras é perdido como resultado da existência desse gap.

No Egito, Dixon, Woodhead e Sohliman (2006) também tiveram como objetivo investigar a existência do AEG entre os auditores e os usuários das demonstrações financeiras. Os autores identificaram a existência do gap relacionado a responsabilidades, como prevenção de fraudes, manutenção de registros contábeis e julgamento e seleção de procedimentos de auditoria. Em menor extensão, foi identificado o gap relacionado à confiabilidade da auditoria e nas demonstrações financeiras auditadas e à utilidade da auditoria.

Sobre essa linha de pesquisa, Fadzly e Ahmed (2004) investigaram a existência do AEG na Malásia e compararam a extensão desse gap com os resultados de Best et al. (2001) sobre os achados desse estudo em Singapura.

Os resultados da pesquisa indicam a presença do AEG e um equívoco sobre auditoria na Malásia. Um grande gap é encontrado principalmente com relação às responsabilidades na detecção e na prevenção de fraude, na preparação das demonstrações financeiras e nos registros contábeis e controles internos. O gap fica mais evidente com relação à responsabilidade legal no caso de ocorrência de fraude.

Haniffa e Hudaid (2007) investigaram se os ambientes social e de negócios afetam a percepção dos usuários e dos auditores sobre o desempenho dos auditores. Utilizando como metodologia questionários e entrevistas, o estudo revelou a existência do gap relacionado a desempenho no que diz respeito às funções especificadas nas normas estatutárias e àquelas que podem ser esperadas pelos auditores na Arábia Saudita.

Os resultados das entrevistas revelam a influência dos mecanismos institucionais e culturais sobre a diferença de expectativas de auditoria e indicam que a inclusão de princípios islâmicos 
em normas de auditoria e do código de ética ajudaria a reduzir a diferença de expectativas que existe na Arábia Saudita.

Assim como nos demais países, os autores encontraram evidências sobre o AEG relacionado a responsabilidades na detecção e na comunicação de fraudes. Enquanto os usuários esperam que os auditores exerçam determinadas funções, os auditores ficam relutantes em fazê-lo uma vez que os pronunciamentos são omissos no tocante a isso. Nesse caso, o gap está relacionado com a deficiência de normas/padrões de auditoria.

Os autores ainda advertem que o corpo regulatório local deveria seriamente considerar a introdução de regras e regulamentações relacionadas à detecção e à comunicação das fraudes, para atender às demandas dos usuários.

Leung e Chau (2001) investigaram o efeito de expandir o relatório do auditor na tentativa de diminuir o AEG em Hong Kong. Para a realidade dessa jurisdição, os autores frisam que, no ano de 1994, o modelo de relatório do auditor foi revisado, e as principais alterações consistiram na inclusão de um parágrafo descrevendo brevemente as responsabilidades do auditor das companhias sobre a preparação das demonstrações financeiras, bem como as suas responsabilidades para expressar uma opinião sobre essas demonstrações.

Os resultados indicam que o relatório do auditor revisado é capaz de trazer mais consenso entre auditores e banqueiros. Os resultados são consistentes com os estudos anteriores que mencionam que a expansão de informações no relatório do auditor melhora a percepção do usuário sobre o processo de auditoria. No entanto, ainda existe um descasamento entre as expectativas banqueiros e auditores. Os banqueiros têm uma alta expectativa de que a companhia esteja livre de fraude depois de um processo de auditoria.

Lin e Chen (2004) investigaram, empiricamente, o aumento do AEG e questões de auditoria relacionadas com o ambiente de negócios e de auditoria na China.

Os resultados demonstram que os beneficiários da auditoria chinesa concordam que, em geral, a função de auditoria deveria melhorar a veracidade e a confiabilidade das demonstrações financeiras e desempenhar um papel positivo para a economia do país.

Os autores ainda ponderam que as diferentes percepções entre os beneficiários da auditoria podem ser atribuídas a ambientes institucionais exclusivos na China. Em uma economia dominada pelo poder do estado e controles governamentais, a função de auditoria é 
inevitavelmente sujeita à intervenção governamental e é empregada substancialmente para o 'cumprimento da auditoria'. A existência do gap significa que os contadores chineses agora preferem limitar suas responsabilidades sobre a detecção de fraude, adotando a linha profissional que prevalece no ocidente.

Monroe e Woodliff (1994) investigaram a existência do AEG na Austrália. O foco da análise foi a introdução de uma nova redação do relatório do auditor, proposta pela Fundação Australiana de Pesquisas em Contabilidade ${ }^{28}$, em 1993. Essa alteração expandiu o parágrafo do escopo, fornecendo mais detalhes sobre as responsabilidades dos diretores na preparação e apresentação das contas, sua natureza, objetivos e limitações da auditoria.

A redação do novo relatório do auditor teve um impacto significativo nas crenças sobre a natureza da auditoria e as responsabilidades dos auditores e da administração. No entanto, essa nova redação também criou novas expectativas entre o auditor e os usuários de seu relatório. Essa diferença é menor, quando se trata de investidores mais sofisticados, quando comparado aos menos sofisticados, e está relacionada com perspectivas futuras das companhias.

Porter, Ó hÓgartaigh e Baskerville analisaram as evidências do AEG na Nova Zelândia e no Reino Unido. O trabalho foi dividido em duas partes: a primeira avaliou o AEG relacionado ao desempenho dos auditores, no ano de 2008, nos dois países (Porter et al., 2012a). Na segunda parte do trabalho, analisaram a evolução do AEG de desempenho de 1989 a 2008 (Porter et al., 2012b).

Os autores consideram que o AEG é formado por dois componentes primários: (i) gap de razoabilidade e (ii) gap relacionado ao desempenho.

No primeiro são esperadas, pela sociedade, que determinadas responsabilidades sejam executadas pelo auditor; e o segundo pode ser dividido em 'deficiências nos padrões/normas', na qual são esperadas pela sociedade determinadas responsabilidades para o auditor que não são requeridas, e 'deficiência no desempenho', nos casos em que o auditor desempenha de forma deficiente suas responsabilidades.

A pesquisa dos autores foi conduzida em 2008 e procurou determinar diferenças na extensão, estrutura e composição do gap de desempenho na Nova Zelândia e no Reino Unido. Os autores concluíram que há uma similaridade nas responsabilidades, compreendendo os componentes

\footnotetext{
${ }^{28}$ Australian Accounting Research Foundation.
} 
do gap de desempenho nos dois países. A extensão desse gap é maior na Nova Zelândia do que no Reino Unido. Segundo os autores, isso pode ser devido ao fato de que no Reino Unido há maior conscientização dos assuntos corporativos e financeiros (relacionados a implicações da auditoria), além do controle mais rigoroso do desempenho dos auditores.

Na segunda parte do trabalho, os autores constataram que, no período em análise, na Nova Zelândia, essas questões atraíram poucos debates públicos, e a diferença no gap de razoabilidade aumentou. As mudanças nas normas de auditoria fizeram com que algumas responsabilidades, que anteriormente eram esperadas dos auditores, se tornassem responsabilidades reais, reduzindo o gap relacionado à deficiência de padrões/normas.

Além disso, o monitoramento do desempenho dos auditores continuou inalterado na Nova Zelândia, enquanto seu rigor só aumentou no Reino Unido. Como consequência, o gap relacionado a desempenho, no Reino Unido diminuiu consideravelmente enquanto na Nova Zelândia só aumentou.

Nos Estados Unidos, McEnroe e Martens (2001) enviaram questionários para os contadores e investidores individuais na tentativa de obter percepções sobre a extensão do AEG. Os autores identificaram a existência da diferença de expectativas, e que os investidores têm expectativas mais altas das várias facetas da auditoria do que os próprios auditores nas seguintes áreas: evidenciação, controles internos, fraude e operações ilegais.

\subsection{Litígios e as firmas de auditoria}

As firmas de auditoria são comumente processadas em contextos de escândalos contábeis e financeiros. Nessas situações, tornam-se mais evidentes as percepções de diversos participantes do mercado sobre o papel da auditoria.

No contexto do entendimento das funções do auditor, não apenas os interessados na empresa como elas próprias identificam responsabilidades atribuídas à auditoria o que pode culminar na participação da firma de auditoria como parte de um processo judicial.

De acordo com Kaplan (1987), em situações de um desastre financeiro, na qual um banco pode ter falido, um investimento não ter mais valor no mercado, um devedor não poder mais pagar suas dívidas, é extremamente tentador processar os contadores envolvidos por uma razão principal: eles ainda são solventes. Eles, frequentemente, são os mais próximos envolvidos que não sofreram financeiramente com o desastre. $O$ tamanho das grandes empresas de 
contabilidade, suas reservas de capital e contratos de seguro as tornam alvos atrativos para os reclamantes que desejam ter de volta seu dinheiro perdido.

Fogarty, Heian e Knutson (1991) analisaram criticamente a resposta do público contábil a essas ocorrências, o passivo legal. Esse passivo decorrente de uma crise é institucional por natureza e, portanto, não há uma solução direta ou óbvia para os casos. As firmas de auditoria, nesse caso, têm agido racionalmente "não fazendo nada" para diretamente mitigar essas perdas legais. A classe vem direcionando uma variedade de outras estratégias para beneficiar os auditores.

Os autores concluem que as situações que envolvem passivos legais não devem ser analisadas de maneira isolada, mas, sim, em conjunto com outras ações relacionadas aos assuntos de sua operação. Isso sugere a existência de planos ligados ao ambiente institucional e ao nível operacional. Com a análise desses dois níveis, é possível entender aparentes inconsistências nas respostas sobre as responsabilidades legais dos contadores. As perdas legais podem ser caracterizadas como uma consequência imediata das contradições implícitas nesses dois níveis.

Pacini, Martin e Hamilton (2000) iniciam seu trabalho, mencionando o crescimento dos litígios nas firmas de auditoria, nas décadas de 1960, 1970 e 1980 em países específicos, que possuem, como característica comum, o sistema jurídico o common law. Alguns reflexos decorrentes do aumento de processos contra as firmas de auditoria podem ser vistos, especialmente nos Estados Unidos e na Austrália:

- As firmas de auditoria estão se tornando mais agressivas em se negar a prestar serviços para empresas que apresentam um alto risco de litígio.

- Diminuição da disponibilidade e aumento no custo com seguro de responsabilidade profissional.

- Aumento do número de contadores experientes deixando de exercer essa especialidade.

Os autores analisaram as decisões judiciais e as legislações dos Estados Unidos, Inglaterra, Canadá, Austrália e Nova Zelândia, países esses que conseguiram reverter a tendência de crescimento dos passivos oriundos de litígios contra as firmas de auditoria. Analisaram, também, com base no sistema legal desses países, quais terceiras partes, ou seja, outros usuários que não o cliente, têm o direito de processar os contadores por negligência de apresentação de informações financeiras. Os autores concluíram que o conhecimento acerca do arcabouço legal 
dos países analisados permite aos contadores fazer uma melhor avaliação da exposição a litígios.

Kimberly, Lowe e Smith (2001) compararam as atitudes de juízes e auditores, em relação à profissão contábil, na tentativa de determinar se existe uma diferença de expectativa entre esses grupos e determinar como essas diferenças podem ter implicações legais para esses profissionais.

Por meio da utilização de questionários, os autores escolheram para o estudo o seguinte público: auditores, juízes e estudantes norte-americanos. Os resultados revelaram divergências com relação à percepção entre auditores, juízes e estudantes no tocante a expectativas sobre a profissão contábil, especificamente sobre o trabalho dos auditores. Esse estudo, portanto, revela que existe uma diferença de percepções sobre o papel do auditor, e que isso tende a influenciar as decisões legais que envolvem as firmas em questão.

Lowe (1994), em seu trabalho, comparou as atitudes de juízes e auditores, especificamente sobre a atividade da auditoria. Como método para pesquisa, utilizou questionários enviados tanto para juízes quanto para auditores norte-americanos. Os resultados desse trabalho revelaram uma divergência na percepção de juízes e auditores sobre as expectativas dessa atividade. $\mathrm{O}$ autor sugere que esse descasamento de expectativas pode levar os juízes a atribuírem responsabilidades aos auditores que estejam relacionadas a atividades que são de responsabilidade da administração. Os principais pontos de desentendimento sobre o papel do auditor são:

- Os juízes do estudo têm dúvidas com relação à responsabilidade sobre demonstração financeira.

- Os juízes percebem os auditores como guardiões e têm expectativa de que procuram ativamente por pequenas fraudes.

- Juízes não concordam que o papel dos auditores seja similar ao de um segurador ${ }^{29}$ (tradução livre desta autora).

O trabalho de Lowe (1994) é importante, pois trata de uma pesquisa empírica que sinalizou essa diferença de entendimento entre juízes e auditores sobre o papel do auditor. O autor, portanto,

\footnotetext{
${ }^{29}$ Texto no original: Judges in our study disagreed with the auditor's role as an insurer.
} 
preocupou-se em capturar essa diferença de entendimento sobre essa atividade. No entanto não foram analisadas, nesse contexto, as evidências finais desse entendimento, as quais são representadas pelas conclusões dos processos judiciais nos quais as firmas de auditoria estão envolvidas.

A attribution theory refere-se a como as pessoas fazem relações causais para explicação de determinado fenômeno, na tentativa de entender as causas dos eventos e as ações em torno deles. De acordo com Jennings, Kneer e Reckers (1993), essa é sem dúvida uma tarefa dos juristas. A tarefa de diagnóstico de um jurista, diante de um incidente de perda, é verificar em qual extensão o auditor é a causa, a situação é a causa ou, mesmo, se o requerente é a causa.

Jennings et al. (1993) destacam duas considerações importantes quando da análise de decisões judiciais. A primeira deve-se ao fato de que as diferenças individuais de cada jurista, relacionadas a atitudes e experiências, podem influenciar significativamente um julgamento. A segunda é que, se as normas que regem a atividade do auditor não estiverem acessíveis, os juristas utilizarão mecanismos de apoio para substituir essas normas.

A segunda observação colocada pelos autores constitui de um ponto importante para o propósito desta pesquisa, pois na ausência do claro entendimento sobre as normas profissionais, os juízes utilizarão o julgamento para estabelecer a relação de causa e efeito da questão legal que chegou até eles. Esse é um campo a ser explorado neste trabalho, especialmente a fundamentação, por parte dos juristas, para concluir sobre um processo contra os auditores.

O trabalho de Palmrose (1987), substancialmente descritivo, trouxe contribuições importantes para o entendimento dos processos que envolveram fraudes e ações legais contra os auditores independentes. A autora procurou descrever o impacto das falhas nos negócios e das fraudes, por parte da administração, em ações contra os auditores independentes nos Estados Unidos. Seguem as principais conclusões da autora:

- Os processos contra os auditores são influenciados pelo clima dos negócios. Em situações de crise econômica, há um aumento de processos contra o auditor.

- Os casos nos quais os auditores foram acusados, aproximadamente metade da amostra analisada envolvia falha nos negócios do cliente ou o cliente passava por situações financeiras severas. 
- A maioria dos casos de processos pertinentes a falências envolvia fraude por parte da administração.

- Fraude estava presente em aproximadamente metade dos casos analisados.

- Casos de fraude por parte da administração foram, em sua maioria, resolvidos por meio de pagamentos, como forma de ressarcir os danos ao auditor. 


\section{RESULTADOS}

\subsection{Análise de processos judiciais cíveis}

\subsubsection{Banco BVA}

Trata-se de um agravo de instrumento, em resposta ao processo administrativo punitivo instaurado pelo Banco Central do Brasil, no caso do Banco BVA, no qual as partes do processo são:

Agravante $^{30}$ : KPMG Auditores Independentes

Agravado: Ministério Público do Estado de São Paulo.

Os seguintes trechos foram utilizados nas argumentações do processo, (BRASIL, 2014a):

Auditoria não é formalidade, mas, sim, pressuposto da confiança do mercado investidor. Nas sociedades anônimas de capital aberto, essas inspeções são obrigatórias e regulamentadas pela CVM, conforme consta do art. $177, \S 3^{\circ}$, da Lei 6404/76 e alvos de críticas de José Edwaldo Tavares Borba (Direito societário, Renovar, 12a edição, 2010, p. 430): “As auditorias, apesar da especialização de que se encontram revestidas, também têm cometido falhas significativas em sua função revisora". (Grifo desta autora)

A pesquisa da doutrina italiana anima escrever que a evolução dos sentidos sobre a responsabilidade dos auditores independentes caminha, a partir de decisão do Tribunal de Torino, de 1993, para a consagração de uma posição próxima ou análoga ao do agente encarregado de um serviço público de conferência e exatidão documental, sendo importante transcrever o trecho da obra de Giuseppe e Matteo Stassano (Il falso in bilancio, Giuffrè Editore, 1996, p. 117, item 9.2): 'Questa tendenza che rafforza il dovere di diligenza dei controllori a ricercare fatti, atti e documenti, falsi o irregolari è in consonanza con l'altra tendenza che vuole qualificare i revisori addirittura come pubblici ufficiali ${ }^{31}$. (Grifo desta autora)

Não é desarrazoado cogitar da magnitude do serviço de auditoria e compará-lo a um agente delegado pelo Estado para conferir segurança aos documentos contábeis reveladores da higidez e normalidade de um banco. Essa diretriz serve, aqui, para entender como razoável a interpretação que oriente para a tutela das vítimas do dano injusto (grifo desta autora).

Com base nos trechos citados, nota-se a ideia de que a auditoria tem função revisora, com o dever de buscar fatos e documentos falsos em busca de irregularidades. Nota-se, também, que a ideia do papel do auditor é a de um profissional responsável pela conferência de documentos contábeis. Embora tenha sido feita menção à Resolução CFC 1.203/09 ${ }^{32}$, quando da referência

\footnotetext{
${ }^{30}$ As firmas de auditoria podem figurar como polo ativo, dependendo do estágio do processo, por terem recorrido a decisão em instância anterior.

${ }^{31}$ Esta tendência que reforça o dever de cuidar dos controladores para buscar fatos, registros e documentos, falsos ou irregulares está em consonância com outra tendência que quer qualificar os auditores mesmo como funcionários públicos.

32 Aprova a NBC TA 200 - Objetivos Gerais do Auditor Independente e a Condução da Auditoria em Conformidade com as Normas de Auditoria.
} 
ao processo administrativo instaurado pelo Bacen, não foram mencionados ou explorados, nos acórdãos, os objetivos do auditor de acordo com a referida Resolução, que aprova a NBC TA 200 - Objetivos Gerais do Auditor Independente e a Condução da Auditoria em Conformidade com as Normas de Auditoria.

Sobre a defesa da firma de auditoria foi considerado o seguinte argumento: "o trabalho de auditoria não apresenta erros ou fraude e que o parecer não é um atestado de idoneidade ou de eficácia de administração de negócios".

Nota-se que os argumentos colocados no acórdão foram considerados por serem relevantes na discussão do caso em questão. A análise desses argumentos deixa evidente a existência de um gap de expectativa com relação ao trabalho do auditor (reasonableness gap).

No respectivo documento, os auditores externos também foram acusados de negligência ou imperícia, relacionados ambos os termos, com a expressão conduta imprópria da firma.

\subsubsection{Engepack}

Trata-se de um agravo de instrumento, em resposta ao processo administrativo, no qual as partes do processo são:

Agravante: Engepack Embalagens S A

Agravado: Deloitte Touche Tohmatsu Auditores Independentes

O processo foi arquivado administrativamente, e por esse motivo não houve uma decisão que condenasse os réus. No acórdão, observa-se a solicitação de condenação dos réus a pagamentos de danos materiais e morais em razão de alegada gestão fraudulenta da autora do processo. $\mathrm{O}$ relatório pontua que essas atividades fraudulentas foram omitidas do relatório de auditoria (BRASIL, 2014b, p. 6):

A demanda é voltada à condenação de todos os réus ao pagamento de indenização por danos materiais e morais em razão de alegada gestão fraudulenta da sociedade empresária autora, com saques indevidos de valores através de cheques descontados na boca do caixa e justificados com notas fiscais, tudo o que teria sido omitido de relatórios de auditoria.

$\mathrm{Na}$ consulta ao agravo retido, que consta em anexo ao processo, é possível obter mais detalhes sobre a argumentação das irregularidades apontadas nesse contexto, especificamente os argumentos de defesa da firma de auditoria. Entre esses argumentos constam (i) o fato de não terem participado dessas irregularidades, (ii) não terem o dever legal de identificar atos ilícitos 
das companhias, o que contava em sua carta de contratação e (iii) o escopo dos trabalhos, na época do acontecido, era limitado ${ }^{33}$.

Nota-se, portanto, que a acusação se pautou no argumento de que era responsabilidade dos auditores divulgarem tais fatos em seu relatório, o que passaria por identificar e descobrir que se tratavam de documentos fraudulentos. No entanto, não foram explorados mais detalhes sobre as responsabilidades do auditor nesse contexto, como a materialidade disso no contexto das demonstrações financeiras. Não foi possível, portanto, identificar AEG de razoabilidade para esse caso.

\subsubsection{Banco Noroeste}

O processo envolve as seguintes partes:

Apelante: Leo Wallace Cochrane

Apelado: Pricewaterhousecoopers Auditores Independentes S/C

O processo encontra-se em julgamento pelo STJ e foi julgado em 2ª instância. Ele também está relacionado com a responsabilidade do auditor com relação a aspectos de fraudes acontecidas dentro das empresas auditadas.

O tema submetido ao enfrentamento concerne às operações fraudulentas praticadas interna corporis, junto ao Banco Noroeste, cuja auditoria, pelos contratos trazidos, competia à empresa Price, sem detectar, diagnosticar, ou se manifestar de maneira mais enfática sobre graves desvios acontecidos (BRASIL, 2013).

Sobre as argumentações constantes no acórdão ainda constam (BRASIL, 2013):

Não se discute que a responsabilidade central, reportada a prevenção e detecção da fraude, diz respeito aos responsáveis pela governança da entidade e de sua administração.

$\mathrm{e}$

O auditor que efetua a auditoria, consoante com as normas específicas, deve colher transparência, segurança razoável para que as demonstrações contábeis como um todo não revelem distorções relevantes, imbricadas por fraude ou erro.

e

\footnotetext{
${ }^{33}$ Revisão de ITR - Informações Trimestrais.
} 
O fato de não se admitir qualquer responsabilidade da Price seria muito cômodo, simplesmente inaceitável, revelando que teria apenas bônus, e nenhum ônus, decorrente do risco profissional assumido (grifo desta autora).

Sobre o primeiro trecho, nota-se a tendência relacionada ao objetivo de detecção de fraudes e erros. Embora tenha sido mencionada a responsabilidade da administração pela detecção de fraude, os demais argumentos não puderam ou exploraram os limites e responsabilidades de cada um desses atores. No segundo excerto, a ideia de que a auditoria é uma apólice de seguro e que comprou determinado risco ao aceitar determinado cliente.

O documento ainda menciona (BRASIL, 2013):

A função primordial da auditoria é de examinar, mesmo no regime de amostragem, de universalidade, discrepâncias, falhas, irregularidades, assimetrias, e não se pode dizer que um rombo tão elevado passe despercebido e constantemente não monitorado pela empresa Price

$\mathrm{e}$

'a independência da auditoria é primordial para o seu trabalho de apontar falhas, irregularidades, graves distorções, fraude’.

A análise desses argumentos demonstra a expectativa de que o auditor independente tenha por função examinar falhas, irregularidades ou erros. Uma visão distorcida que não menciona em momento algum o objetivo de aderência às normas contábeis aplicáveis. A ideia desse argumento está muito mais próxima de uma atividade policialesca do que o próprio objetivo de uma auditoria independente. O objetivo do auditor independente não é a identificação de falhas ou erros, muito embora tenha que endereçar trabalhos caso se depare com isso no decorrer de sua atividade.

Mais adiante, observa-se o seguinte trecho (BRASIL, 2013):

É certo que a auditoria zela pela eficiência dos dados contábeis e pela saúde financeira da empresa' e ainda 'A empresa de auditoria é contratada para fiscalizar, analisar e monitorar as questões financeiras de outra empresa, auditada. (Grifo desta autora).

Esse argumento também traz uma expectativa de que a empresa de auditoria está relacionada ou se responsabiliza, de alguma maneira, com a gestão da empresa. Essa afirmação novamente remete ao gap de razoabilidade, especificamente no que tange à atividade de avaliar a eficiência e a efetividade da gestão da companhia auditada.

Aqui vale remeter novamente à norma de auditoria NBC TA 240 (CFC, 2009b) que menciona: 
O auditor que realiza auditoria de acordo com as normas de auditoria é responsável por obter segurança razoável de que as demonstrações contábeis, como um todo, não contêm distorções relevantes, causadas por fraude ou erro. Conforme descrito na NBC TA 200, devido às limitações inerentes da auditoria, há um risco inevitável de que algumas distorções relevantes das demonstrações contábeis podem não ser detectadas, apesar de a auditoria ser devidamente planejada e realizada de acordo com as normas de auditoria (NBC TA 200, item 51).

Nota-se, portanto, as diversas menções sobre as responsabilidades do auditor. No início do documento, os argumentos mencionados guardam relação com as normas. No entanto, durante o desenvolvimento da argumentação, notam-se diversas atribuições e expectativas que não encontram respaldo nas normas profissionais. Conforme descrito anteriormente, este trabalho não tem por objetivo entrar no mérito da decisão dos juízes envolvidos nos processos que fazem parte da amostra e, portanto, não serão discutidas se esses argumentos são razoáveis no contexto de todo o processo.

\subsubsection{Banco Santos}

O processo trata de uma indenização por danos materiais no qual o autor pretende $o$ ressarcimento da quantia que diz ter perdido em investimentos financeiros junto ao Banco Santos. O processo foi julgado improcedente.

Apelante: Alexandre Matone

Apelado: Ernst \& Young Terco Auditores Independentes S/S

Na argumentação da conclusão, foram mencionados os seguintes trechos (BRASIL, 2012a, p. 9):

O trabalho da auditoria em testilha fora elaborado exclusivamente pela ré à diretoria da instituição financeira, não tendo o serviço sido prestado para o autor, ou sequer sido disponibilizado, de maneira geral, ao mercado de consumo.

Nessa perspectiva, não estava o autor obrigado a direcionar seus recursos disponíveis às aplicações financeiras do Banco Santos e, se o fez, foi exclusivamente por sua conta e risco.

Se tomou tal decisão valendo-se (quer por ingenuidade, quer por inexperiência, quer por qualquer outra razão de foro íntimo) de parecer de auditoria que sequer para si próprio houvera sido realizada, o liame causal acha-se, na espécie, caracterizado entre o dano suportado e a sua própria decisão de ali investir, mas não (como pretende o autor) entre referido dano e o trabalho de auditoria realizado pela ré para a diretoria do banco, o qual, em relação ao autor, não passa de documento inteiramente inter alios.

O fato do autor do processo requerer uma indenização da empresa de auditoria denota uma expectativa de que o parecer de auditoria funcionasse como um "atestado" de saúde financeira da empresa. A conclusão desse caso pautou-se mais na relação jurídica e contratual existente 
entre a instituição financeira em questão e a empresa de auditoria prestadora de serviço. Não houve, portanto, nenhuma argumentação, por parte de juiz, no presente acórdão, de que a auditoria teria responsabilidades sobre isso. Não foi possível identificar, portanto, para esse caso, uma diferença de expectativa com relação ao trabalho da auditoria por parte do juiz.

\subsubsection{Sociedade Hebraico Brasileira Renascença}

A autora do processo, Sociedade Hebraico Brasileira Renascença, alega ter tomado decisões estratégicas para a empresa concomitante a um contexto de fraude, o que teria prejudicado financeiramente a companhia. $\mathrm{O}$ processo foi extinto, com julgamento de mérito, desfavorável à autora.

Apelante: Sociedade Hebraico Brasileira Renascença

Apelado: Ernst \& Young Terco Auditores Independentes SS

A decisão contempla tanto os argumentos da empresa autora do processo quanto os da firma de auditoria. É possível identificar diversos trechos nos quais a autora acusa a firma de auditoria de executar determinados procedimentos que seriam de dever do profissional, o que poderia ocasionar, se objeto dessa análise, em diferenças de expectativas relacionadas ao desempenho do trabalho do auditor. A autora ainda defende que "o descobrimento de fraude deve ser um dos objetos da auditoria" (BRASIL, 2014c, p. 547). Aqui novamente a discussão acerca da responsabilidade sobre fraudes.

No entanto o juiz deu esse caso por encerrado e não foi possível identificar, com base no documento analisado, a existência de diferenças de expectativa com relação ao trabalho do auditor.

\subsubsection{Banco Econômico}

Apelante: Ministério Público Federal e Banco Excel Econômico

Apelado: Ernst Young Auditores Independentes

O acórdão disponível para esse processo trata-se de uma decisão interlocutória do processo (embargo de declaração). Nessa decisão, não foi explorada a responsabilidade do auditor para o propósito da pesquisa. Além disso, foi obtida uma decisão de um dos juízes do processo. De 
acordo com esse documento, foi possível obter as razões pelas quais a firma de auditoria estava sendo acusada (BRASIL, 2010):

a) a empresa de auditoria ora recorrida não ressalvou o fato de o Banco Econômico ter omitido nas notas explicativas evento subsequente a 30/6/95 com efeito relevante sobre sua situação financeira e resultados futuros; b) não fez constar parágrafo de ênfase referente aos problemas de liquidez da instituição; c) não fez qualquer ressalva à delicada situação financeira do banco; b) não haveria razão plausível para que a dita empresa de auditoria independente, que figurou como auditoria externa do Banco Econômico, deixasse de fazer a necessária ressalva à situação financeira extremamente dificultosa em que o banco se encontrava".

A decisão do juiz ainda contempla o seguinte argumento:

Dessa forma, em tal perspectiva, tenho que a responsabilidade civil da ora apelada está devidamente patenteada em razão da culpa que também reconheço em razão de sua atuação como empresa que foi contratada para a realização de controle externo do Banco Econômico. Acompanho, portanto, o voto de Vossa Excelência. (Grifo desta autora)

Foi feita a tentativa de obter mais documentos relacionados a esse processo, como a decisão do órgão de primeira instância, nesse caso o TJDF, mas essa também não está disponibilizada. No acórdão que está no website do TRF1, consta a informação de que o processo tramitou em segredo de justiça. O atual status do processo é de baixado em definitivo em outubro de 2015.

Embora não se tenha uma discussão acerca da responsabilidade do auditor, percebe-se, pelo documento de voto mencionado, que a empresa de auditoria foi contratada para realização de controle externo do Banco Excel Econômico, o que poderia ser um indicativo de existência de AEG de razoabilidade. No entanto, devido à falta de mais discussões e documentos disponíveis, não foi possível concluir sobre a existência de AEG de razoabilidade.

\subsubsection{Basf}

Agravante: KPMG Auditores Independentes

Agravado: Basf S.A.

O relatório de auditoria produzido pela empresa KPMG foi utilizado pela Basf para aquisição de um estabelecimento comercial, que alegou ter sofrido prejuízos por conta de tal transação (BRASIL, 2015a). A formalização dos acórdãos arquivados no processo detalha mais as formalizações no âmbito do direito civil e não abordou de forma suficiente, para o objetivo do trabalho em questão, os argumentos prós e contra o caso. Foram consultados também outros documentos anexados ao processo porém, após a leitura desses materiais, não foi possível identificar a existência de AEG por parte dos juízes envolvidos no processo. 


\subsubsection{Banco Nacional}

Sobre o caso do Banco Nacional, foram encontrados mais de um processo, no Supremo Tribunal Federal e no Superior Tribunal de Justiça. A Tabela 12 mostra mais detalhes sobre eles:

Tabela 12 - Processos Banco Nacional

\begin{tabular}{|c|c|c|c|c|c|}
\hline Tribunal & Número do Processo & Auditoria & Companhia & Tipo/ Ação & Vara/ Tribunal \\
\hline 1 STJ & $\begin{array}{l}\text { AREsp n }{ }^{\circ} \mathbf{9 8 6 4 3} / \\
\text { SP (2011/0198292- } \\
\text { 8) }\end{array}$ & $\begin{array}{l}\text { Agravante: } \\
\text { KPMG } \\
\text { Auditores } \\
\text { Independentes }\end{array}$ & $\begin{array}{l}\text { Banco } \\
\text { Nacional }\end{array}$ & $\begin{array}{l}\text { Agravo em } \\
\text { recurso } \\
\text { especial }\end{array}$ & $\begin{array}{l}\text { Tribunal de } \\
\text { origem: TJSP }\end{array}$ \\
\hline 2 STJ & $\begin{array}{l}\text { AREsp n } \text { n }^{\mathbf{8 8 5 6 8}} / \\
\text { SP(2011/0197588-5) }\end{array}$ & $\begin{array}{l}\text { Agravante: } \\
\text { KPMG } \\
\text { Auditores } \\
\text { Independentes }\end{array}$ & $\begin{array}{l}\text { Banco } \\
\text { Nacional }\end{array}$ & $\begin{array}{l}\text { Agravo em } \\
\text { recurso } \\
\text { especial }\end{array}$ & $\begin{array}{l}\text { Tribunal de } \\
\text { origem: TJSP }\end{array}$ \\
\hline 3 STJ & $\begin{array}{l}\text { AREsp n }{ }^{\circ} \mathbf{1 4 0 5 3 8} / \\
\text { DF(2012/0040106- } \\
\text { 7) }\end{array}$ & $\begin{array}{l}\text { Agravado: } \\
\text { KPMG } \\
\text { Auditores } \\
\text { Independentes }\end{array}$ & $\begin{array}{l}\text { Banco } \\
\text { Nacional }\end{array}$ & $\begin{array}{l}\text { Agravo em } \\
\text { recurso } \\
\text { especial }\end{array}$ & $\frac{\text { Tribunal de }}{\underline{\text { origem: TJDFT }}}$ \\
\hline 4 STJ & $\begin{array}{l}\text { REsp n }{ }^{\circ} \mathbf{1 2 8 3 7 3 7} / \\
\text { DF(2011/0223035- } \\
6)\end{array}$ & $\begin{array}{l}\text { Recorrido: } \\
\text { KPMG } \\
\text { Auditores } \\
\text { Independentes }\end{array}$ & $\begin{array}{l}\text { Banco } \\
\text { Nacional }\end{array}$ & $\begin{array}{l}\text { Recurso } \\
\text { especial }\end{array}$ & $\begin{array}{l}\frac{\text { Tribunal de }}{\text { origem: TRF da }} \\
\frac{1^{\text {a }} \text { região. }}{}\end{array}$ \\
\hline
\end{tabular}

Fonte: Elaborada por esta autora

\subsubsection{AREsp n $\quad 98643$}

Trata-se de uma ação indenizatória por danos materiais decorrente de investimento feito pelo autor em ações do Banco Nacional, que um mês depois sofreu intervenção do Banco Central e posteriormente foi decretada sua liquidação.

Nos argumentos da justificativa do voto, foram mencionados outros processos relacionados (como o AREsp n ${ }^{\circ}$ 88568) e a conclusão do processo pelo Banco Central do Brasil. Sobre as responsabilidades do auditor menciona-se (BRASIL, 2015b, p. 1): “Afirmou o autor que realizou os investimentos em razão dos pareceres de auditoria da requerida, a qual, contudo, deixou de detectar e revelar a verdadeira situação econômico-financeira do banco" (Grifo desta autora).

No entanto, trata-se de uma afirmação sobre a acusação e não se pode considerar que o juiz responsável concordasse com isso. Além desses argumentos, foi também apontada uma conduta negligente por parte da firma de auditoria. 
Ainda com relação a esse processo, procurou-se por mais informações no tribunal de origem, nesse caso o TJSP. O processo encontra-se arquivado administrativamente e, portanto, não há um documento de acórdão disponível para consulta.

\subsubsection{AREsp n $n^{0} 88568$}

Esse processo é similar ao AREsp no 98643 pois trata-se de ação indenizatória por danos materiais decorrentes de investimento feito pelo autor em ações do Banco Nacional. Claramente foram considerados a decisão e os argumentos do Tribunal de origem para esta decisão: "O Tribunal de origem se debruçou minuciosamente sobre os elementos de prova juntados a estes autos para concluir pela responsabilidade da recorrente" (BRASIL, 2011a, p. 4).

E sobre os argumentos utilizados pelo Tribunal de origem: "Pois bem. Marco Aurélio Diniz Maciel, um dos sócios da KPMG, era o responsável pela auditoria no Nacional, sua obrigação de detectar as fraudes que maquiaram a contabilidade dessa instituição" (BRASIL, 2011a, p. 5). (Grifo desta autora)

Com relação à argumentação para decisão nessa instância (BRASIL, 2011a, p. 7):

Citando estudos técnicos juntados aos autos, inclusive, com referência às respectivas folhas, o acórdão consignou que a negligência premeditada da empresa de auditoria foi determinante para que o agravado investisse o dinheiro no Banco Nacional, que estava com saldo negativo há certo tempo, mas cujos resultados eram intencionalmente acobertados. (Grifo desta autora)

Tem-se, pelo excerto acima, a ideia de que o parecer de auditoria é um atestado de segurança e de saúde financeira da companhia auditada. Já com relação ao trecho que faz referência ao Tribunal de origem, afirma-se que a empresa de auditoria é responsável pela detecção de fraudes dentro da companhia. Não foram mencionadas ou exploradas as limitações e contexto dos trabalhos de auditoria, nem as responsabilidades da administração nos documentos analisados. Considera-se, portanto, a existência de AEG de razoabilidade.

\subsubsection{AREsp no 140538}

Para esse processo, havia apenas a decisão monocrática disponível no STJ, e esse documento foi considerado para a análise.

O processo tem a mesma natureza de ação indenizatória como observado nos casos anteriores. Trata-se de um agravo interposto de um recurso especial que impugna um acórdão do TJDFT. 
Importante considerar a referência que foi feita a decisão desse acórdão (BRASIL, 2012b, p. $1)$ :

Os pareceres e balanços patrimoniais emitidos e divulgados por empresas de auditoria e consultoria contábil não podem ser interpretados como garantia de viabilidade da entidade financeira ou atestado de eficácia da administração na gestão dos negócios. (Grifo desta autora)

Nota-se aqui a ideia incorreta de que as firmas de auditoria também são responsáveis pela emissão das demonstrações financeiras da companhia auditada. Novamente não se faz menção às responsabilidades da administração sobre as próprias demonstrações financeiras.

Além do trecho citado, não foi explorado ou nem considerado nenhum argumento com relação às responsabilidades do auditor no contexto do processo. Embora não se tenha sido mais explorada a responsabilidade do auditor no documento, nota-se no argumento em destaque acima que existe a ideia do auditor ser responsável pela elaboração do balanço patrimonial da companhia. Com base nisso, considera-se, portanto, a existência de AEG de razoabilidade.

Adicionalmente, foi também pesquisada a conclusão do processo no tribunal de origem, nesse caso no TJDFT, no entanto o processo encontra-se arquivado.

\subsubsection{REsp n ${ }^{0} 1283737$}

O processo foi aberto pelo Ministério Público visando ao ressarcimento dos prejuízos sofridos pelos acionistas da instituição financeira, em processo de liquidação extrajudicial, devido à alegação de fraude e conduta irregular dos réus.

A argumentação contra a empresa de auditoria, feita pelo Ministério Público (BRASIL, 2011b), é a de que ela:

Não atuou com a diligência esperada das empresas de auditoria externa, atestando balanços irreais, ensejando prejuízos aos acionistas, diante da falsa impressão de regular operação do Banco no Sistema Financeiro Nacional. (Grifo desta autora)

Nesse caso, tem-se a expectativa de que a auditoria serve como uma garantia, um atestado de saúde financeira da empresa auditada.

Com relação às responsabilidades do auditor, o tema não foi explorado nos documentos analisados. Como o trecho foi considerado para contextualizar o documento, não é possível afirmar se de fato essa era a opinião do juiz responsável por esse caso. Então, não foi identificada a existência de AEG de razoabilidade. 
Com base em todos os casos analisados, é possível afirmar, para o propósito desta pesquisa, a existência de AEG de razoabilidade em pelo menos 2 (dois) dos acórdãos. Atribui-se ao auditor independente, responsabilidades sobre detecção de fraudes, além da ideia de que o parecer de auditoria é um atestado de saúde financeira da empresa auditada. Além desses argumentos, uma característica que se deve mencionar é o fato de considerar as decisões em outras instâncias, ou mesmo por outro regulador, como o Bacen. Sem dúvida, como parte de um processo de julgamento, isso deve ser levado em consideração. No entanto, se houver qualquer equívoco nas esferas inferiores, no que tange a um conceito específico como o discutido neste trabalho, esse equívoco também deve ser levado para as instâncias superiores.

\subsection{Análise de processos administrativos - CVM}

\subsubsection{Saraiva}

Acusados: Deloitte Touche Tohmatsu Auditores Independentes e Maurício Pires de Andrade Resende (sócio técnico responsável - DTT).

Nesse caso, a companhia aberta Saraiva S.A. - Livreiros Editores, na divulgação de suas Informações Trimestrais - ITR, de março de 2010, informou que no período em questão não realizou operações com derivativos, quando a companhia apresentava posição comprada em contrato a termo de dólar, operações consideradas como instrumentos financeiros derivativos (CVM, 2011).

Os auditores, por sua vez, são acusados de não terem emitido relatório de revisão especial com ressalva sobre tais demonstrações contábeis, devido à não evidenciação em nota explicativa específica sobre a realização desse tipo de transação.

A discussão, nesse caso, baseou-se no fato de que não se tratavam de operações materiais para o tipo de trabalho executado pelo auditor independente. Foi levado em consideração a NPA $06^{34}$, que estabelece critérios para determinação desses tipos de procedimentos por parte dos auditores.

\footnotetext{
${ }^{34}$ Norma e Procedimento de Auditoria - Revisão Especial das Informações Trimestrais das Companhias Abertas.
} 
Não foi explorado, no acórdão, as responsabilidades do auditor dentro do contexto desta pesquisa. Não foi possível identificar a existência de AEG de razoabilidade para esse processo administrativo sancionador.

\section{Acórdão CRSFN (1133314)}

Para esse caso, o Colegiado da CVM resolveu acatar as razões de defesa e decidiu inocentar os indiciados sob o fundamento de que:

i) trata-se de revisão especial de informações trimestrais, com diferença de escopo em relação à auditoria de demonstrações financeiras;

ii) as operações eram de pequena expressão material;

iii) as notas explicativas devem se referir à divulgação de fatos relevantes (Ministério da Fazenda, 2014a).

No entanto, houve recurso de ofício interposto pela autoridade de origem.

Sobre a justificativa dos votos, foram utilizados os seguintes argumentos:

É certo que a Inst. CVM 308, de 1999, em seu art. 25, I-“d”, determina que o auditor independente deve se certificar sobre eventual descumprimento de dispositivos legais e regulamentares, que implique reflexos relevantes na estrutura patrimonial ou de resultados da instituição auditada.

Art. 25. No exercício de suas atividades no âmbito do mercado de valores mobiliários, o auditor independente deverá, adicionalmente:

I - verificar: (...)

d) o eventual descumprimento das disposições legais e regulamentares aplicáveis às atividades da entidade auditada e/ou relativas à sua condição de entidade integrante do mercado de valores mobiliários, que tenham ou possam vir a ter reflexos relevantes nas demonstrações contábeis ou nas operações da entidade auditada (Ministério da Fazenda, 2014a).

O CRSFN manteve a decisão do Colegiado e a absolvição dos indiciados, nesse caso, a empresa de auditoria.

Com base nas justificativas do voto, também não foi possível identificar a existência de AEG da razoabilidade.

\subsubsection{Semp Toshiba}

Acusados: Ernst \& Young Auditores Independentes, Adilson Birolli Gonzalez (sócio E\&Y), Semp Toshiba Amazonas S.A. e administradores da companhia envolvida.

Processo refere-se às relações mantidas entre controladora e controlada, o que envolvia contratos mútuos e pagamentos da controlada para a controladora e entre outros fatos que poderiam prejudicar os minoritários. 
As argumentações do processo relacionam-se fundamentalmente com o desempenho do trabalho da auditoria, como a suficiência dos testes feitos, conclusões e evidências sobre determinados assuntos pertinentes à empresa.

A acusação contra a empresa de auditoria baseia-se no fato de:

Não terem se aprofundado nos exames de auditoria quando da emissão dos pareceres relativos às demonstrações financeiras da Semp Toshiba SA e se omitirem no concernente ao relacionamento comercial e financeiro entre Semp Toshiba SA e sua controladora, que favoreciam a essa última, em detrimento dos acionistas minoritários (CVM, 2004a, p. 6).

Na conclusão do relatório aponta-se:

Assim, entende-se que o parecer da auditoria exarado pela Ernst \& Young atendeu às normas pertinentes, tendo constatado a fidedignidade das demonstrações contábeis por ela regularmente examinadas através de testes que visavam à obtenção de evidências contra insuficiente exatidão e validade dos dados produzidos pelo sistema contábil da empresa auditada (grifo desta autora) (CVM, 2004a, p. 9).

Nota-se, portanto, que além das questões de desempenho discutidas na conclusão do processo, tem-se a ideia de que a empresa de auditoria deva interferir em aspectos de gestão e estratégia das empresas auditadas. Isso porque na conclusão do processo não foi apontada nenhuma irregularidade de procedimentos efetuada pela firma de auditoria, estando ela, assim, de acordo com as normas da CVM. Trata-se, portanto, do AEG de razoabilidade.

Além disso, a menção de que o relatório do auditor "constatou fidedignidade", traz a ideia de tratar-se de um atestado, uma certificação sobre as demonstrações financeiras.

Sobre a representação fidedigna dos relatórios contábil-financeiro, o CPC menciona (CPC, 2011, item QC12): "Para ser representação perfeitamente fidedigna, a realidade retratada precisa ter três atributos. Ela tem que ser completa, neutra e livre de erro. É claro, a perfeição é rara, se de fato alcançável. O objetivo é maximizar referidos atributos na extensão que seja possível".

Ainda sobre a discussão de fidedignidade de acordo com o CPC:

Representação fidedigna não significa exatidão em todos os aspectos. Um retrato da realidade econômica livre de erros significa que não há erros ou omissões no fenômeno retratado, e que o processo utilizado, para produzir a informação reportada, foi selecionado e foi aplicado livre de erros. Nesse sentido, um retrato da realidade econômica livre de erros não significa algo perfeitamente exato em todos os aspectos. Por exemplo, a estimativa de preço ou valor não observável não pode ser qualificada como sendo algo exato ou inexato. Entretanto, a representação dessa estimativa pode ser considerada fidedigna se o montante for descrito claramente e precisamente como sendo uma estimativa, se a natureza e as limitações do processo 
forem devidamente reveladas, e nenhum erro tiver sido cometido na seleção e aplicação do processo apropriado para desenvolvimento da estimativa (CPC, 2011, item QC15).

Nota-se que o conceito de fidedignidade se relaciona com a realidade econômica e que também é inexato. Se o fato de um erro ou omissão de alguma informação não for material para o conjunto das demonstrações financeiras, não faz sentido o auditor opinar sobre isso. Isso deve ser frisado e destacado quando se utiliza o argumento de que o auditor tem responsabilidades na descoberta de fraudes e erros. Caso contrário, tem-se a impressão de que o auditor é o responsável pela "certificação" da demonstração financeira.

Portanto, no caso acima analisado, conclui-se a existência de AEG de razoabilidade.

\section{Acórdão CRSFN (8325/08)}

Nesse caso, houve revisão da conclusão do processo pela CRSFN. Sobre os argumentos da decisão do voto, foi considerado o mesmo trecho mencionado, presente no relatório da decisão do Colegiado (Ministério da Fazenda, 2008a):

Entende-se que o parecer da auditoria exarado pela Ernst \& Young atendeu às normas pertinentes, tendo constatado a fidedignidade das demonstrações contábeis por ela regularmente examinadas através de testes que visavam à obtenção de evidências contra insuficiente exatidão e validade dos dados produzidos pelo sistema contábil da empresa auditada. (Grifo desta autora)

A conclusão do CRSFN foi a mesma decisão do Colegiado, que decidiu pela absolvição dos indiciados. Com base na análise dos argumentos, também não foi identificada a existência de AEG de razoabilidade.

\subsubsection{ALL}

Acusados: Ernst \& Young Auditores Independentes e Marcos Antonio Quintanilha (sócio E\&Y).

A acusação refere-se à ausência de ressalva nos pareceres de auditoria, de três períodos subsequentes, frente ao erro na avaliação do passivo decorrente de pagamento em ações de contrato de arrendamento mercantil.

O argumento da acusação relaciona-se ao fato da empresa de auditoria "não ter exercido um julgamento crítico e imparcial sobre o fato e nem sobre o valor reconhecido na contabilidade" e ainda "caber ao auditor a responsabilidade de verificar a adequação das informações prestadas 
pela companhia às práticas contábeis adotadas no Brasil, expressando de forma clara e objetiva sua opinião no parecer de auditoria" (CVM, 2009, p. 2).

Ainda sobre a argumentação dos autores "em geral, entendem a função da auditoria como opinião a respeito da fidedignidade das demonstrações contábeis e que implica, também, a descoberta de fraudes e erros, bem como informação quanto aos controles internos da companhia" (Grifo desta autora) (CVM, 2009, p. 5), o que denota a existência do AEG sobre as responsabilidades do auditor com relação à detecção de fraudes.

Assim como em outros casos analisados neste trabalho, a responsabilidade sobre fraudes não foi explorada, pelo menos com base no que foi transcrito para os acórdãos, nessa discussão. Nem tampouco foi mencionada a responsabilidade primária da administração sobre a detecção de fraude. A leitura do documento remete à ideia de que de fato essa responsabilidade é única e exclusivamente do auditor.

Conforme discutido no processo da Semp Toshiba, o conceito de fidedignidade relaciona-se com a realidade econômica e também é inexato. No caso de uma omissão ou erro não relevante no contexto das demonstrações financeiras, não faz sentido o auditor opinar sobre isso. Isso deve ser frisado e destacado quando se utiliza o argumento de que o auditor tem responsabilidades na descoberta de fraudes e erros. Caso contrário, tem-se a ideia de que o auditor é o responsável pela "certificação" da demonstração financeira.

A conclusão dos responsáveis pelo julgamento, que não condenou a Ernst \& Young, fez menção ao argumento utilizado pela acusação, sobre a responsabilidade na descoberta de fraudes e não explorou mais o tema, com base no acórdão. Embora o assunto tenha sido mencionado, o mérito da questão era a falta de menção no relatório do auditor sobre uma determinada transação da companhia. Então não se tem como propósito para a pesquisa, para esse caso, relacionar a discussão de responsabilidade do auditor com a condenação da empresa de auditoria.

Como na conclusão do processo foi considerada a ideia de fidedignidade e responsabilidade de fraude e erros sem delimitar as responsabilidades do auditor, considera-se a existência de AEG de razoabilidade para esse caso.

\section{Acórdão CRSFN (1123614)}

A decisão do Colegiado da CVM foi revista pelo CRSFN. No documento de voto, foram retomados os seguintes argumentos do Relator, membro do Colegiado, sobre o caso: 
Os auditores independentes entendem a função da auditoria como exame atinente à fidedignidade das demonstrações contábeis sob que se debruçam, o que implica a descoberta de fraudes e erros, bem como a prestação de informações acerca dos controles internos da companhia (Grifo desta autora) (Ministério da Fazenda, 2014b).

Nota-se, portanto, a utilização de diversos argumentos utilizados pelo Relator, dentre eles, a responsabilidade por detecção de fraudes e a responsabilidade sobre a fidedignidade das demonstrações financeiras.

Assim, 'a auditoria independente exerce uma função de interesse público e apresenta como produto final o seu parecer. A sua opinião influencia aqueles investidores que, em seu processo de tomada de decisão, tomam por boa essa certificação e que, na hipótese de essa opinião não apresentar ressalvas, são levados a acreditar nos números divulgados pela companhia' (Grifo desta autora) (Ministério da Fazenda, 2014b).

Pelo excerto, destaca-se a ideia de que o parecer do auditor se trata de uma certificação das demonstrações financeiras da empresa, o que remete ao conceito incorreto de que a auditoria é uma 'apólice de seguro'. Importante mencionar o Prof. Dr. Nelson Carvalho que diz "a visão maniqueísta de que a auditoria "verifica" ou "certifica" algo que é o objetivo e possui única resposta ou que existe uma "verdade" contábil a ser assegurada é inadequada e pouco contribui ao funcionamento do mercado de capitais". Trata-se, portanto, de uma ideia equivocada de atribuir ao auditor a responsabilidade de asseguração absoluta sobre as demonstrações financeiras.

As breves citações acima atestam a importância para o mercado de capitais da boa atuação dos auditores independentes, cabendo lembrar, ainda, que diversos órgãos reguladores inserem em seus normativos a obrigatoriedade de sua presença', sendo certo que a Comissão de Valores Mobiliários, a seu turno, 'estabelece regras que objetivam a clareza e a exatidão das demonstrações financeiras, bem como a independência e a capacitação dos auditores externos das companhias abertas (Grifo esta autora) (Ministério da Fazenda, 2014b).

Com base no trecho destacado, também se faz referência à ideia de exatidão das demonstrações financeiras. De acordo com o IASB, “em grande medida, os relatórios financeiros baseiam-se em estimativas, julgamentos e modelos e não em representações exatas" (IASB, 2010). Novamente, não foi trazido para a discussão o fato de a administração exercer seus próprios julgamentos para determinar suas melhores representações no balanço da empresa, quando necessário, e o fato do auditor também exercer o seu julgamento sobre essas avaliações da administração.

Por fim, a decisão do CRSFN considerou: 
Nesse contexto, não me parece que os Recorridos tenham violado a NBC T 11 - IT - 3 - Fraude e Erro, aprovada pela então vigente Resolução n. ${ }^{\circ}$ 836, de 1999, do Conselho Federal de Contabilidade, cujo item 17 dispunha que, "se o auditor concluir que a fraude elou erro têm efeito relevante sobre as demonstrações contábeis, e que isso não foi apropriadamente refletido ou corrigido, ele deve emitir seu parecer com ressalva ou com opinião adversa", porquanto tinham convicção ponderável, dadas as circunstâncias, de que não havia erro a apontar, agindo, no exercício de suas atribuições legais e regulamentares, segundo o que razoavelmente se poderia esperar de quem obra de acordo com o padrão de diligência profissional esperado dos auditores independentes (Ministério da Fazenda, 2014b).

A utilização do trecho da NBC T 11 demonstra que foram utilizadas como referência, durante a discussão do processo, as normas profissionais do auditor independente, e que elas delimitam a responsabilidade do auditor no descobrimento de fraude. Embora a firma de auditoria não tenha sido condenada por não indicação em relatório de auditoria sobre a obrigação de doação em pagamento de ações, houve uma discussão nas partes iniciais do acórdão sobre as responsabilidades do auditor. Embora esse não tenha sido o mérito do processo, a discussão do assunto é importante para o objetivo desta pesquisa no que tange à identificação da existência do AEG de razoabilidade.

Portanto, embora a empresa de auditoria não tenha sido condenada no caso específico desse processo, as responsabilidades do auditor foram discutidas no acórdão, e com base nisso identificou-se a existência de AEG de razoabilidade. Aqui, especificamente, o AEG de razoabilidade pode não ter trazido prejuízos à firma de auditoria, mas nota-se que a existência do gap de razoabilidade pode ocasionar um passivo legal para essas firmas. Para esse caso, então, conclui-se sobre a existência de AEG de razoabilidade em ambas instâncias.

\subsubsection{Parcom Participações S.A.}

Indiciados: KPMG Auditores Independentes e Vânia Andrade de Souza (sócia KPMG).

Trata-se de um processo no qual a empresa de auditoria é acusada de não ter emitido um relatório de auditoria com ressalva, sobre um assunto controverso, relacionado à reavaliação de ativo intangível e gastos associados à aquisição e à formação de atletas de futebol.

As argumentações tanto da acusação quanto da defesa relacionam-se estritamente às normas contábeis aplicáveis para empresas de futebol e os julgamentos feitos pelo auditor com relação a questões específicas.

A decisão contra a empresa de auditoria levou em consideração as orientações a seguir Normas Brasileiras de Contabilidade - NBC-T-11 (CVM, 2004b, p. 11): 
11.1.1.1 - A auditoria das demonstrações contábeis constitui o conjunto de procedimentos técnicos que tem por objetivo a emissão de parecer sobre a sua adequação, consoante os Princípios Fundamentais de Contabilidade e as Normas Brasileiras de Contabilidade e, no que for pertinente, a legislação específica.

11.1.1.2 - Salvo declaração expressa em contrário, consoante do parecer, entende-se que o auditor considera adequadas e suficientes, para o entendimento dos usuários, as informações divulgadas nas demonstrações contábeis, tanto em termos de conteúdo quanto de forma.

11.3.9.1.- $\mathrm{O}$ auditor independente deve assegurar-se de que as demonstrações contábeis das controladas e/ou coligadas, relevantes, utilizadas para fins de consolidação ou contabilização dos investimentos pelo valor do patrimônio líquido na controladora e/ou investidora, estão de acordo com as disposições contidas no item 11.1.1.1.

- Instrução CVM no 308/99 (CVM, 2004b, p. 12):

Art. 20. O Auditor Independente - Pessoa Física e o Auditor Independente - Pessoa Jurídica, todos os seus sócios e integrantes do quadro técnico deverão observar, ainda, as normas emanadas do Conselho Federal de Contabilidade - CFC e os pronunciamentos técnicos do Instituto Brasileiro de Contadores.

Nota-se, portanto, que foram consideradas as normas de auditoria, e que os argumentos entre a acusação e as partes acusadas foram no âmbito técnico-contábil. Nesse cenário, não foi identificado AEG de razoabilidade por parte dos envolvidos na decisão do caso.

\subsubsection{Ribeirão Preto Water Park S.A.}

Indiciados: KPMG Auditores Independentes, Fernando Octavio Sepúlveda Munita (sócio KPMG), Banco JP Morgan S/A, NorChem Holdins e Negócios S/A e administradores e conselheiros das empresas envolvidas.

Trata-se de um processo instaurado para averiguar eventuais irregularidades na gestão da empresa Ribeirão Preto Water Park. A KPMG foi acusada de não cumprir as normas de auditoria independente no que tange suas responsabilidades sobre as demonstrações financeiras da empresa auditada. O relatório em questão refere-se à ITR de 1996, e o processo foi julgado em 2004.

O problema refere-se especificamente à falta de divulgação, no relatório do auditor independente, sobre os problemas de continuidade da empresa auditada.

Os seguintes argumentos foram utilizados pelo Conselheiro-Relator (CVM, 2004c, p. 14):

No que tange às DFs referentes ao exercício social findo em 31.12.95, divulgadas em 23.04.96 (fls. 105/175), observo que, embora tenham os debenturistas, em assembleia geral realizada em 05.01.96, aprovado a proposta de revisão orçamentária, o que levaria a uma majoração do 
orçamento para a construção do parque. Tal evento subsequente deveria ter sido indicado nas demonstrações financeiras referentes ao exercício social encerrado em 31.12.95, nos termos do art. $176, \S 5^{\circ}$, da Lei Societária.

Da mesma forma, não obstante a $1^{\text {a }}$ ITR/1996, divulgada em 23.05.96 (fls. 118/132), nada informasse sobre a aprovação da segunda revisão orçamentária por parte do conselho de administração da companhia (o que ocorreu em 20.05.96), o relatório de revisão dos auditores independentes não ressalvou os problemas orçamentários do empreendimento (fls. 132). Por fim, no relatório de revisão dos auditores independentes referente à $3^{\mathrm{a}}$ ITR/1996, divulgada em 14.11.96 (fls. 14.11.96), embora grande a probabilidade de descontinuidade do empreendimento, não fizeram os auditores nenhuma ressalva (Grifo desta autora).

Com base nos excertos, vê-se o entendimento de que o auditor deveria ressalvar os problemas orçamentários da companhia, o que a princípio não se configura como um dos objetivos do auditor. No entanto, entende-se, pelo contexto da argumentação, que a ressalva seria no sentido de advertir os usuários sobre os problemas de continuidade operacional da companhia.

Sobre isso, o Conselho Federal de Contabilidade (CFC, 2009c, item 6), por meio da Resolução CFC 1.226 de 2009, menciona que:

A responsabilidade do auditor é obter evidência de auditoria suficiente sobre a adequação do uso, pela administração, do pressuposto de continuidade operacional na elaboração e apresentação das demonstrações contábeis e expressar uma conclusão sobre se existe incerteza significativa sobre a capacidade de continuidade operacional.

A ausência de qualquer referência à incerteza de continuidade operacional, no relatório do auditor independente, não pode ser considerada uma garantia da capacidade de continuidade Operacional.

À época do relatório do auditor, a norma de auditoria aplicável mencionava que (IBRACON, 1995, item 25):

Se o auditor concluir que ainda persistem dúvidas quanto à continuidade normal das operações, deve assegurar-se de que seja feita adequada divulgação, em nota explicativa, dos principais fatores que geraram tais dúvidas. Tal divulgação deve chamar atenção para a possibilidade de que a entidade possa ser incapaz de continuar suas atividades e, se for o caso, de realizar seus ativos e cumprir com suas obrigações. Mesmo que a divulgação seja adequada, o auditor deve acrescentar um parágrafo de ênfase em seu parecer, após o parágrafo de opinião, fazendo referência à respectiva nota explicativa que discute os fatos.

O auditor foi condenado ao pagamento de multa. No entanto, nesse caso, não ficou claro, pela análise dos argumentos da conclusão do processo, a existência do AEG de razoabilidade, uma vez que a interpretação das partes envolvidas sobre as responsabilidades do auditor frente a condições de incerteza não foi explorada com a profundidade necessária para que se pudesse identificar o AEG de razoabilidade para o propósito desta pesquisa. 


\subsubsection{Perdigão S.A.}

Acusados: KPMG Auditores Independentes, José Luiz Ribeiro de Carvalho e Charles Krieck (ambos sócios da KPMG).

Nesse caso, a empresa de auditoria está sendo acusada de não emitir ressalva em seu relatório, com relação ao procedimento contábil de amortização integral do ágio, que o regulador julgou inadequado. Como parte da argumentação dos responsáveis pela decisão do processo constam os seguintes trechos:

De início, destaco que a auditoria exerce função de interesse público e, em geral, é entendida como opinião a respeito da fidedignidade das demonstrações contábeis; implicando, também, a descoberta de fraudes e erros, bem como em informação quanto aos controles internos da companhia (Grifo desta autora) (CVM, 2010a, p. 5).

O processo de tomada de decisão do investidor, por seu turno, é influenciado pelo parecer da auditoria independente, sendo o investidor levado a acreditar nos números divulgados pela companhia quando essa opinião não apresenta ressalvas (CVM, 2010a, p. 5).

Ao ser mencionado que a opinião do auditor está relacionada com a fidedignidade das demonstrações contábeis, a leitura do documento sugere, conforme já discutido neste trabalho, que o relatório do auditor é uma apólice de seguro. Mais adiante, também se menciona a responsabilidade do auditor com relação a fraudes. Novamente, tem-se a ideia de que o auditor é o responsável pela detecção de fraudes, de forma geral, dentro da companhia. Não foi mencionado, na conclusão do processo, que a administração é a responsável primária pela detecção de fraudes. Nesse caso, podemos considerar a existência de AEG de razoabilidade, uma vez que se percebe uma diferença de expectativas com relação ao trabalho da auditoria.

\section{Acórdão CRSFN (1153315)}

A empresa de auditoria foi condenada ao pagamento de multa sob a alegação de descumprimento da Instrução CVM 308/99. Os acusados, no entanto, entraram com recurso contra essa decisão.

Os seguintes argumentos foram considerados na decisão do voto (Ministério da Fazenda, 2015a, p. 9):

O auditor emite sua opinião sem ressalva quando evidencia que as demonstrações contábeis da empresa auditada foram elaboradas de acordo com as normas e práticas contábeis adotadas. A ressalva, por sua vez, é inserida quando o auditor conclui que o efeito de qualquer discordância ou restrição na extensão de um trabalho poderá afetar as demonstrações contábeis. Já um parecer que contém parágrafos de ênfase existe quando há incerteza em relação ao fato 
relevante, cujo desfecho poderá afetar significativamente a posição patrimonial e financeira da entidade.

Após a discussão técnica dos fatos e circunstâncias do processo, ainda (Ministério da Fazenda, 2015a, p. 10):

Como descrito na norma Ibracon 02/90 (item 9): Na revisão especial, ao invés de expressar uma 'opinião', o auditor declara que, baseados nos procedimentos mínimos preestabelecidos, ele não tem conhecimento de qualquer modificação relevante que deva ser feita nas informações financeiras revisadas para que as mesmas estejam adequadamente apresentadas de acordo com as bases descritas.

No caso, havia sim modificação relevante e, por isso, deveria ter sido feita a ressalva. Por isso, entendo correta a condenação.

Com base na análise do respectivo acórdão, não foi identificada, portanto, a existência de AEG de razoabilidade.

\subsubsection{Unibanco}

Indiciados: Unibanco - União de Bancos Brasileiros S.A., César Augusto Sizenando Silva, PricewaterhouseCoopers Auditores Independentes e Ricardo Baldin (sócio da PwC).

O processo tem por objetivo a investigação de irregularidades relativas aos aspectos legais e regulamentares em fundos administrados pelo Unibanco. A PricewaterhouseCoopers foi acusada de omissão de comunicação à CVM dos atos supostamente irregulares na gestão dos fundos de investimentos.

Sobre a opinião dos juízes envolvidos no caso, foi mencionado como embasamento para tal acusação o seguinte trecho da Instrução CVM 216/94 (CVM, 2001, p. 9):

Art. 29 - São deveres do auditor independente no exercício de suas atividades no âmbito do mercado de valores mobiliários:

I - ...omissis...

II - elaborar relatório circunstanciado, a ser endereçado à administração da entidade auditada, contendo observações a respeito das deficiências ou da ineficácia dos controles internos e procedimentos contábeis da entidade auditada; III - comunicar à Comissão de Valores Mobiliários - CVM circunstâncias que possam configurar atos praticados pelos administradores em desacordo com as disposições legais e regulamentares aplicáveis às atividades da entidade auditada e/ou relativas à sua condição de entidade integrante do mercado de valores mobiliários, atos estes que tenham, ou possam vir a ter reflexos sobre as demonstrações contábeis auditadas e eventuais impactos nas operações da entidade;

E ainda os seguintes trechos relacionados à interpretação da norma (CVM, 2001, p. 10) :

a. Quanto ao inciso II do art. 29, não há nos autos nada que indique, nem mesmo remotamente, a "ineficácia dos controles internos e procedimentos contábeis da entidade auditada". Seja 
quanto aos desenquadramentos, seja quanto às operações prejudiciais, eles não decorreram de ineficácia de controles ou de procedimentos contábeis, mas sim de falhas de gestão (Grifo desta autora).

b. Já quanto ao inciso III do art. 29, embora a comunicação à CVM quanto ao desenquadramento e as operações pudesse ter ocorrido - e fosse mesmo desejável que tivesse ocorrido —, não há qualquer prova de que os auditores tenham tido conhecimento de tais falhas, ou que não tenham realizado os testes por amostragem destinados a verificá-las (Grifo desta autora).

c. Além disso, e principalmente, a norma do inciso II exige que os atos a serem comunicados pelos auditores, sejam atos que "tenham, ou possam vir a ter reflexos sobre as demonstrações contábeis auditadas e eventuais impactos nas operações da entidade", o que, seja pela eventualidade dos desvios, seja pelo seu valor irrelevante, definitivamente não se verificou.

Com base na análise dos trechos acima, é possível observar que além da menção do papel do auditor com base na norma do regulador, foi mencionado também que (i) trata-se de uma falha de gestão, (ii) a realização de testes por amostragem para avaliação dos controles internos da entidade e (iii) a exigência de comunicação com o regulador relacionados de assuntos relevantes no contexto das demonstrações financeiras. Nesse caso, portanto, não foi identificada a existência do AEG de razoabilidade sobre as atribuições do auditor.

\section{Acórdão CRSFN (380902)}

A decisão do Colegiado da CVM foi revista pelo CRSFN. Não foi explorado na formalização do acórdão a responsabilidade dos auditores. Além disso, foi mantida a decisão do Colegiado de arquivar o processo com relação à empresa de auditoria, por não ter sido demonstrada omissão por parte dos auditores contratados (Ministério da Fazenda, 2002). O fato do processo ter sido arquivado denota a inexistência de AEG de razoabilidade para esse caso.

\subsubsection{Barreto de Araújo Produtos de Cacau S.A. (BAP)}

Acusados: Gilvandro Fróes Marques Lobo, Jacy Flósculo Goulart, José Duarte Barbosa de Almeida, Nelson Oliveira Fiúza Lima, Price WaterHouse Coopers Auditores Independentes, Ricardo de Agostini Logoeiro e Yuan Shi Hwa

O processo foi aberto contra os administradores da companhia, devido a diversas irregularidades. Os auditores, $\mathrm{PwC}$, foram acusados de (i) não emitirem um parecer conclusivo quanto à adequação das demonstrações financeiras do exercício de 31.12 .1989 , (ii) não emitirem uma ressalva quanto ao desvio do objeto social da empresa auditada e (iii) não apresentação de ressalva com relação à não constituição de provisão para devedores duvidosos. 
Com relação aos argumentos da decisão são mencionados:

(i) Não emissão de parecer sobre as demonstrações financeiras de um exercício social (CVM, 2010b, p. 13):

Ao contrário da acusação, ante o pedido formulado pela própria BAP à Price, de que aguardasse a conclusão de negócio para a emissão do relatório, não vislumbro como a conduta desta última poderia ter sido diversa. A despeito do papel, mais amplo, que as empresas de auditoria deveriam ter no mercado de valores mobiliários - tornado ainda mais claro com a introdução das novas regras contábeis -, fato é que incumbe aos administradores da companhia aberta, nos termos do art. 133, § $3^{\circ}$, da LSA, a publicação de cópia das DFs (inciso II) e do parecer dos auditores independentes (inciso III). E que, sem as DFs, não há que se falar em parecer. Discordo, portanto, da lógica da acusação, de acordo com a qual, com a expressa concordância dos auditores independentes com o pleito da administração da BAP de retardar a emissão do relatório e parecer sobre as DFs de 31.12.1989, deveria sobre a Price recair responsabilidade por "colaborar" com aquela postura da administração da Companhia.

(ii) Desvio do objeto social (CVM, 2010b, p. 13):

28. Sem prejuízo das considerações já feitas, quanto ao fato de que, a meu ver, ter-se-ia efetivamente operado um desvirtuamento do escopo da BAP, mais uma vez sou da opinião de que a imputação formulada extrapola o limite das responsabilidades atribuídas pela regulamentação então em vigor aos auditores. Nesse sentido, penso não ser razoável admitir que estes deveriam ser capazes de, naquele contexto, exercer juízo quanto a eventual desvio de objeto social da Companhia (Grifo desta autora).

Sobre os argumentos relacionados ao item (iii), foram levados em consideração aspectos técnicos que não permitiram a identificação de elementos para o propósito desta pesquisa. Considerando os trechos extraídos da conclusão do processo, nota-se que foi feita menção às responsabilidades do auditor frente à Lei das Sociedades por Ações ("Lei das S.A.s") de que a responsabilidade pela elaboração e divulgação das demonstrações financeiras auditadas é da companhia. Atribuir essa responsabilidade ao auditor é um dos aspectos mencionados por Porter (1990) como característico do gap de razoabilidade. O mesmo raciocício, utilizado pela acusação, pode ser aplicado quanto à responsabilidade de averiguação de desvio do objeto social da empresa auditada.

O fato de o juiz (diretor-relator) e dos demais juízes do Colegiado terem discordado dos argumentos da acusação e terem absolvido a maioria das acusações do processo da empresa de auditoria, no que tange às responsabilidades do auditor independente, permitem a conclusão de não existência de AEG, exclusivamente com base na análise das justificativas presentes no documento de conclusão do processo.

\section{Acórdão CRSFN (1133114)}


A empresa de auditoria recorreu da decisão do Colegiado para o CRSFN. A decisão do PAS, no Colegiado, foi a pena de advertência pelo fato da auditoria não ter ressalvado a não constituição de provisão para devedores duvidosos por parte da companhia auditada. Sobre as demais acusações, a PwC foi absolvida.

Os seguintes argumentos foram utilizados no voto dessa instância (Ministério da Fazenda, 2014c):

Assim, verifico que ficaram caracterizadas a materialidade e a autoria dos ilícitos, nos termos
da decisão condenatória da autoridade de origem, e que os recorrentes não apresentaram
contraprovas ou argumentos que pudessem desconstituir as imputações iniciais ou os
fundamentos da decisão condenatória, em razão do que sou pela confirmação das penalidades
aplicadas, pelos próprios fundamentos da decisão da autoridade de origem.
Também nada tenho a opor às absolvições de que se trata nos autos. Primeiro, porque não havia
como emitir parecer sobre a adequação das demonstrações financeiras da BAP referentes ao
exercício social encerrado em 31.12 .1989 , inclusive porque as demonstrações financeiras ainda
não haviam sido formalizadas, no aguardo da conclusão de negociaçôes que, na visão dos
administradores da companhia, teriam influência positiva nos números que seriam refletidos no
balanço daquela data-base. Em segundo lugar, porque, embora tenha havido desvirtuamento do
objeto social da BAP, tenho dúvidas se era imperativa a obrigatoriedade de os auditores
independentes comunicarem a ocorrência à CVM, até porque comportava uma avaliação
específica quanto a eventual ocorrência de desvio do objeto social da companhia (Grifo desta
autora).

Nesse caso, foi mantida a decisão do Colegiado. É importante salientar que no excerto citado, o Conselheiro-Relator mencionou ter dúvida com relação à responsabilidade do auditor de comunicar a CVM sobre um eventual desvio do objeto social da companhia auditada. Essa incerteza está relacionada com o AEG de padrões deficientes. De acordo com Porter (1990), um dos elementos de maior destaque nessa parte refere-se à expectativa que se tem de que os auditores reportem qualquer tipo de irregularidade para as devidas autoridades locais.

Embora tenha sido identificada a existência de AEG de padrões deficientes, não foi identificado, com base na leitura dos acórdãos do processo, o AEG de razoabilidade.

\subsubsection{Bebidas Antarctica Polar SA}

Acusados: Companhia Brasileira de Bebidas (atual denominação da Companhia Antarctica Paulista IBBC), Companhia de Bebidas das Américas - Ambev, Empresa de Administração e Participações S/A - Ecap, PriceWaterhouse Coopers - Auditores Independentes, Nardon, Nasi \& Cia. Auditores Independentes (atual Nardon, Nasi Auditores Independentes), Fundação Antonio e Helena Zerrenner Instituição Nacional de Beneficência e administradores e controladores das empresas envolvidas. 
O processo foi aberto contra os administradores e controladores da companhia, sob a alegação de diversas irregularidades no período que antecedeu o cancelamento do registro da empresa como companhia aberta. A PwC foi acusada de não ter ressalvado em seu parecer de auditoria que os mútuos foram publicados consolidando saldos não compensáveis entre si e que, portanto, não houve a devida transparência nas demonstrações financeiras (CVM, 2006).

A argumentação utilizada pelo juiz pela aplicação de pena de advertência fez menção à NBC T $11^{35}$ e normativos específicos da CVM. A advertência dada ao auditor foi relativa ao fato de não ter apresentado ressalva para um assunto considerado relevante e material para o Colegiado. Não foi discutida a responsabilidade do auditor, no sentido de sua atividade, uma vez que a discussão foi preponderantemente técnica-contábil. Sendo assim, não foi possível identificar, para o propósito deste trabalho, a existência de AEG de razoabilidade.

\section{Acórdão CRSFN (837308)}

Foi interposto recurso por parte dos acusados. Sobre a decisão do CRSFN, cabe destacar o seguinte (Ministério da Fazenda, 2008b):

Em relação à imputação de elaboração de parecer sem ressalvas em face dos lançamentos contábeis a título de ajuste, em que pesem os argumentos produzidos pela Recorrente às fls. 3417 a 3442, considero correta a decisão do Colegiado da CVM, consubstanciada no Voto de fls. 3298 a 3325, em face do disposto na Instrução CVM 59/86 e sua Nota Explicativa.

Assim, entendo que as empresas de auditoria deixaram indevidamente de ressalvar, em seus pareceres relativos aos exercícios sociais de 1998, 1999 e 2000, que os mútuos foram publicados consolidando saldos não compensáveis, e que as demonstrações não guardaram a devida transparência em relação a operações com partes relacionadas, bem como, especificamente à Price, também no que se refere à movimentação da conta lucros acumulados e ao resultado do exercício social de 2000.

Com base no descrito acima, o foco da argumentação foi a relevância das transações supostamente irregulares e o fato do auditor não mencionar isso em seu relatório. Não foi possível identificar a existência de AEG de razoabilidade nos acórdãos em questão.

\subsubsection{Union National Fundo de Investimento em Direitos Creditórios}

\section{Acusados: Cláudio Rogélio Sertório (sócio KPMG) e KPMG Auditores Independentes}

Nesse processo, a KPMG é acusada de emitir parecer sobre as demonstrações financeiras da cliente sem ressalva sobre a provisão para créditos de liquidação duvidosa do fundo.

\footnotetext{
${ }^{35}$ NBC T 11 - Normas de Auditoria Independente das Demonstrações Contábeis.
} 
A KPMG foi condenada a pagamento de multa pecuniária devido a questionamentos sobre a suficiência dos procedimentos de auditoria efetuados para análise da deterioração da carteira de crédito em questão. O principal normativo levado em consideração foi a NBC T 11, normativo aplicável à época, que tratava de estimativas contábeis (CVM, 2015):

O auditor deve se assegurar da razoabilidade das estimativas, individualmente consideradas, quando estas forem relevantes. Tal procedimento inclui, além da análise da fundamentação matemático-estatística dos procedimentos utilizados pela entidade na quantificação das estimativas, a coerência destas com o comportamento da entidade em períodos anteriores, as práticas correntes em entidades semelhantes, os planos futuros da entidade, a conjuntura econômica e suas projeções.

Com base nos argumentos analisados no processo, verifica-se, portanto, tratar-se de um caso de discussão de desempenho do auditor. Assim, não foi possível identificar a existência de gap de razoabilidade.

\subsubsection{Lojas Arapuã}

Indiciados: KPMG Auditores Independentes, Fernando Octávio Sepúlveda Munita (sócio KPMG), acionistas e administradores da companhia envolvida.

O processo foi aberto contra os administradores das Lojas Arapuã e contra os respectivos auditores, a KPMG. A alegação contra a firma de auditoria deve-se ao fato de não terem mencionado nos pareceres a não evidenciação, por parte da administração, de determinadas contingências passivas que deveriam constar nas demonstrações financeiras de 1996 e 1997 (CVM, 2003).

No caso desse processo, as argumentações do juiz responsável pela decisão também foram baseadas na discussão do desempenho dos auditores com relação ao tema em questão. Não foi identificado, portanto, a existência de AEG relacionado à razoabilidade para esse caso.

\section{Acórdão CRSFN (565304)}

Como o desfecho desse processo, para a KPMG, foi uma multa por descumprimento de normativo específico da CVM, a referida empresa de auditoria entrou com recurso, questionando essa decisão (Ministério da Fazenda, 2004).

$\mathrm{Na}$ justificativa do voto, não foram exploradas as afirmações sobre o papel e as responsabilidades do auditor. Foi mantida a decisão da primeira instância. Não foi possível, portanto, identificar a existência de AEG de razoabilidade nos acórdãos em questão. 


\subsection{Análise de processos administrativos - Bacen}

\subsubsection{Banco Excel Econômico}

Recorrente: Deloitte Touche Tohmatsu Auditores Independentes

Recorrido: Banco Central do Brasil

Nesse caso, a empresa de auditoria é acusada de emitir um parecer sem ressalva para a demonstração financeira do Banco Excel Econômico, para o exercício findo em 31.12.1997, especificamente sobre o fato da situação de iliquidez de créditos diferidos na agência Bahamas daquele grupo financeiro.

Não foram exploradas, nas argumentações do juiz do CRSFN, as responsabilidades da empresa e auditoria mediante tal fato. Observou-se, no entanto, pela argumentação presente no voto da decisão de 1 a instância, no julgamento do Banco Central, que condenou o auditor a pagamento de multa, o seguinte entendimento sobre o papel do auditor:

A auditoria independente é um processo de análise das demonstrações contábeis, para verificação de sua adequação às normas pertinentes, e a finalidade dessa verificação é conferir credibilidade às informações, que, por serem testadas e analisadas por pessoa independente da administração da empresa, oferecem maior segurança aos usuários dos demonstrativos contábeis (Grifo desta autora) (Ministério da Fazenda, 2005).

Mesmo não tendo sido explorada a responsabilidade do auditor, nota-se que a decisão levou em consideração a argumentação da decisão de 1 ạ instância que menciona a ideia de que o auditor tem como responsabilidade "verificar" as demonstrações financeiras. Aqui, novamente, tem-se a ideia de que o relatório do auditor é um "atestado" para os usuários. Para esse caso, considerase, portanto, a existência de AEG de razoabilidade. Adicionalmente, não foi especificado qual conjunto de normas foi levado em consideração (trecho: 'adequação às normas pertinentes').

Além desse entendimento, foi discutido o desempenho da empresa de auditoria, mais especificamente a suficiência dos trabalhos efetuados pelo auditor independente no que tange à matéria em questão.

\subsubsection{Banco Santos}

Recorrentes: Ernst \& Young Auditores Independentes e Adilson Birolli Gonzalez Recorrido: Banco Central do Brasil 
Processo contra a firma de auditoria por não apresentar ressalva relativa ao valor de mercado de contratos de opções na carteira do banco. Por esses valores não corresponderem aos valores negociados.

A discussão em torno dos fatos baseou-se fundamentalmente no desempenho do auditor, sua criticidade e suficiência de procedimentos de auditoria para tal fato. Aqui, novamente, poderia haver algum indicativo de AEG relacionado ao desempenho.

Sobre os normativos e os argumentos da decisão em 1a instância, consta apenas os seguintes trechos (Ministério da Fazenda, 2012):

$\mathrm{O}$ auditor deve planejar seu trabalho de forma a detectar fraudes e erros que impliquem efeitos relevantes nas demonstrações contábeis, conforme os termos da NBC T 11, item 11.1.4.3, e ao emitir seu parecer sem ressalvas deverá ter procurado assegurar-se da inexistência de desvios relevantes nas demonstrações financeiras (Resolução CFC 607/85, em seu inciso III, subitem $3)$.

A Autarquia entendeu que não foram cumpridos os procedimentos e as obrigações pertinentes à execução dos trabalhos de auditoria, ficando evidente, como atesta a documentação acostada aos autos, que os indiciados não realizaram e não agiram com a diligência devida, ao validarem demonstrações financeiras não condizentes com a real situação econômico-financeira do Banco Santos.

Pelos trechos citados, não foi possível identificar a existência de AEG de razoabilidade. Com base na decisão, os acusados recorreram ao CRSFN.

No que diz respeito à decisão do CRSFN, destacam-se excertos de dois conselheiros diferentes:

Finalmente, não vejo como afastar a responsabilidade dos indiciados, sob o argumento de que o papel do auditor independente não é o de identificar e descobrir fraudes. Valho-me, aqui, das observações lançadas na decisão do Banco Central, sobre o papel do auditor independente, no sentido de que o auditor deve planejar seu trabalho de forma a detectar fraudes e erros que impliquem efeitos relevantes nas demonstrações contábeis, conforme estabelecem os termos da NBC T 11, item 11.1.4.3, de modo que ao emitir seu parecer sem ressalvas deverá ter procurado assegurar-se da inexistência de desvios relevantes nas demonstrações financeiras (Resolução CFC 607/85, em seu inciso III, subitem 3) (Ministério da Fazenda, 2012).

Inicialmente, discordo da defesa na medida em que afirma não ter a auditoria independente função de detecção de fraudes. Apesar de não se tratar de finalidade precípua da atividade de auditoria, cada vez mais tem sido atribuída função pública à sua atuação, em razão de sua natureza de gatekeeper. É certo, porém, que essa característica atribuída às Auditorias Independentes tem crescido de importância nos últimos anos, especialmente diante das sucessivas fraudes detectadas nos últimos anos, não havendo, à época, o mesmo rigor atualmente disposto na legislação que trata da matéria (Grifo desta autora) (Ministério da Fazenda, 2012).

Pelos excertos, percebe-se que os Conselheiros mencionaram a responsabilidade sobre detecção de fraudes relacionando-as ao contexto dos trabalhos de auditoria e a materialidade no contexto das demonstrações financeiras. O segundo trecho faz ainda menção de que se trata de um tema 
discutido de forma recorrente, e que a atribuição dessa função ao auditor é feita por ele realizar trabalhos independentes sobre as demonstrações financeiras da entidade auditada (gatekeeper). Não foi mencionada ou sequer explorada a atribuição dessa função à luz das normas profissionais de auditoria, a capacitação desse profissional para exercer essa função ou mesmo mencionado o papel do auditor forense nesse contexto.

Com base nos excertos mencionados, considera-se a existência de AEG de razoabilidade para fins deste trabalho.

\subsubsection{Banco Bandeirantes}

Recorrentes: KPMG Auditores Independentes e Walter Iório (sócio KPMG)

$\underline{\text { Recorrido: }}$ Banco Central do Brasil

A empresa de auditoria é acusada de omissão em seus relatórios da não existência de provisão para perdas, em volume suficiente, para cobrir o significativo volume de créditos líquidos que compunham os ativos daquela instituição financeira.

As argumentações que constam no documento de decisão do processo estão pautadas nos procedimentos executados pela auditoria independente sobre os fatos em questão. Segue o único trecho que faz referência às responsabilidades da firma de auditoria: "A ausência de manifestações da KPMG, em relação ao diferimento das operações problemáticas, consubstancia a inobservância da NPA $02^{36}$ do Ibracon” (Ministério da Fazenda, 2010).

Com base na análise do documento, não foi identificada a presença de AEG de razoabilidade para o propósito desta pesquisa.

\subsubsection{Banco Panamericano}

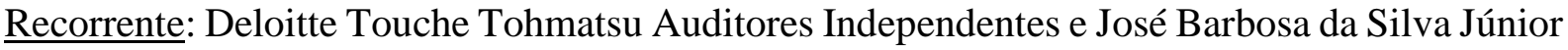
(sócio DTT).

\section{Recorrido: Banco Central do Brasil}

Trata-se de um processo administrativo instaurado contra a Deloitte sob a alegação de emitir parecer sem ressalva referente às demonstrações financeiras que não refletiam a real situação econômico-financeira do Banco Panamericano S.A., para a data-base de 30/06/2010. A referida

\footnotetext{
${ }^{36}$ NPA 02 - Procedimentos de Auditoria Independente de Instituições Financeiras e Entidades Equiparadas.
} 
empresa de auditoria foi acusada de não ter efetuado procedimentos adequados, induzindo ao erro os usuários das informações. O principal problema da demonstração financeira da empresa auditada foi a contabilização irregular de ativos insubsistentes referentes a créditos cedidos (R\$ 1.404,7 milhões), bem como a falta de registro de passivos decorrentes de operações relativas a contratos cedidos com co-obrigação ( $\mathrm{R}$ \$ 673,8 milhões).

Embora a análise das decisões dos juízes seja o propósito deste trabalho, vale mencionar um dos argumentos da defesa da empresa de auditoria que vem ao encontro das polêmicas sobre as responsabilidades sobre fraudes (Ministério da Fazenda, 2015b):

É absolutamente incorreta e falsa a ideia de que auditores independentes seriam responsáveis por realizar atividades policialescas;

A Deloitte não foi contratada para investigar fraudes, mas, sim, para (...) realizar auditoria regular das demonstrações financeiras de 30/06/2010.

Sobre os argumentos do Conselheiro-Relator, decisão em 1a instância, seguem os trechos mais importantes (Ministério da Fazenda, 2015b):

\begin{abstract}
Embora as normas que norteiam a atividade de auditoria independente afirmem que não é objetivo principal de uma auditoria externa descobrir fraudes praticadas pela administração, mas possibilitar que o auditor expresse uma opinião sobre as informações coligidas, registradas ou não nos livros da companhia, e o impacto dessas informações na situação financeira da sociedade, por outro lado, afirmam em uníssono que o auditor independente deve planejar seu trabalho de forma a detectar erros ou fraudes significativas, que tenham ou possam vir a ter um impacto nas demonstrações financeiras da companhia: (Grifo desta autora)

A responsabilidade primária na prevenção e detecção de fraudes e erros é da administração da entidade, através da implementação e manutenção de adequado sistema contábil e de controle interno. Entretanto, o auditor deve planejar seu trabalho de forma a detectar fraudes e erros que impliquem efeitos relevantes nas demonstrações contábeis." (NBC T 11.1.4.3)

Dessa forma, o Bacen entendeu constatada a ocorrência da irregularidade pela emissão de parecer sem ressalva, decorrente da não adoção de procedimentos de auditoria adequados e suficientes. A emissão de parecer sem ressalva representou risco de repercussões negativas, não apenas em relação à instituição auditada, mas também em relação aos seus clientes, acionistas, credores e ao Sistema Financeiro Nacional, pois as demonstrações financeiras ficaram inservíveis para os fins a que se destinavam. Os pareceres de auditoria objetivam oferecer confiabilidade a informações utilizadas por operadores e investidores em suas tomadas de decisão (Grifo desta autora).
\end{abstract}

$\mathrm{Na}$ argumentação da $1 \underline{\text { a }}$ instância, foi mencionada a responsabilidade da administração pela detecção de fraudes e as responsabilidades dos auditores, com base na NBC T 11. Sobre a confiabilidade nas informações, o que está implícito nesse conceito? Aderência às normas, "atestado" de liquidez da companhia auditada ou ausência de fraudes? Isso não é claro pelo texto. De qualquer forma, o conceito de confiabilidade das demonstrações contábeis foi substituído pelo de representação fidedigna na estrutura conceitual dos relatórios financeiros 
(tanto pelo IASB quanto pelo CPC). A representação fidedigna, por seu turno, é uma característica qualitativa da informação contábil-financeira (Ministério da Fazenda, 2015b):

Para ser útil, a informação contábil-financeira não tem só que representar um fenômeno relevante, mas tem também que representar com fidedignidade o fenômeno que se propõe representar. Para ser representação perfeitamente fidedigna, a realidade retratada precisa ter três atributos. Ela tem que ser completa, neutra e livre de erro. É claro, a perfeição é rara, se de fato alcançável. O objetivo é maximizar referidos atributos na extensão que seja possível (CPC, 2011).

Além do trecho citado, que faz menção à responsabilidade da administração sobre a detecção de fraudes, o conteúdo da parte que contém a justificativa do voto dos conselheiros também apresenta diversos trechos que discutem a suficiência dos procedimentos de auditoria feitos para as operações de crédito em questão.

Com relação às argumentações dos conselheiros responsáveis pela decisão do CRSFN, é importante destacar o seguinte (Ministério da Fazenda, 2015b):

3. Inicialmente, discordo da defesa na medida em que afirma não ter a auditoria independente função de detecção de fraudes. Apesar de não se tratar de finalidade precípua da atividade de auditoria, cada vez mais tem sido atribuída função pública à sua atuação, em razão de sua natureza de gatekeeper. Como tem sido cada vez mais comum a existência de questionamentos acerca desse conceito, entendo pertinente tecer algumas considerações acerca de quais são suas funções, bem como suas responsabilidades.

4. Gatekeepers são intermediários responsáveis pela verificação e, eventualmente, certificação de serviços e produtos disponibilizados a investidores. Dentre esses serviços, menciono a verificação de demonstrações contábeis (auditores independentes), avaliação das condições de crédito de companhias e produtos (agências de rating), análise de companhias e de prospectos (analistas de investimento), avaliação de equidade e comutatividade de determinada transação comercial (Bancos de Investimentos ao emitir Fairness opinion) ou mesmo, como defendido por alguns ${ }^{37}$, serviços advocatícios, quando esses emprestam sua reputação para garantir a credibilidade da operação. Enfim, o principal ativo dos gatekeepers é sua reputação no mercado.

5. Por outro lado, a reputação lhes é garantida por meio de uma atuação confiável. Usualmente o mercado acaba dando maior credibilidade aos gatekeepers pelo fato de terem menores incentivos para mentir do que quem está envolvido com a operação. Em princípio, como sua reputação no mercado é seu principal ativo, não seriam eles, em tese, capazes de sacrificar esse ativo reputacional construído muitas vezes após longos anos para beneficiar um cliente específico. Serviriam eles como verdadeiras bússolas, apontando a seus clientes o caminho a ser seguido. Nesse sentido, Kraakman ${ }^{38}$ entende os gatekeepers como atores que detêm a capacidade de monitorar e controlar, ou ao menos influenciar, a conduta de seus clientes corporativos de forma a dissuadir eventual desejo de transgressão da norma (Grifos desta autora).

\footnotetext{
${ }^{37}$ COFFEE, John C. Understanding Enron: It's About the Gatekeepers, Stupid. Working Paper n. 207, July 30, 2002. Retrieved from http://ssrn.com/abstract_id=325240

${ }^{38}$ KRAAKMAN, Reinier H. Corporate Liability Strategies and Costs of Legal Controls, 93 Yale L.J. 858, 890 (1984);
} 
6. A principal função desses atores, de acordo com os ensinamentos de Ronald Coase ${ }^{39}$, é reduzir os custos na obtenção de informações pelo mercado. Ou seja, os investidores teriam muitos gastos tentando obter, de forma independente, informações acerca dos integrantes do sistema de distribuição do mercado ${ }^{40}$, razão pela qual associar esses entes reputacionais a uma entidade ou a um determinado produto tem a função de certificá-los, resolvendo em grande medida o problema da assimetria informacional. Ganha a sociedade que o contrata, em razão da redução dos custos referentes ao acesso de informações fidedignas por parte de agentes do mercado, e ganha o próprio mercado diante do aumento da transparência que a medida proporciona. No caso específico dos auditores independentes, portanto, a sua atuação certifica ao mercado a lisura das informações e dos procedimentos do auditado. Podem ser chamados, portanto, de intermediários reputacionais.

7. Diante dessa função atribuída aos gatekeepers, pergunta-se: o que se espera de sua atuação? Inicialmente, entendia-se que a necessidade de garantir seu principal ativo - a reputação - seria suficiente para prevenir uma atuação defeituosa por parte desses profissionais, entretanto, alguns escândalos financeiros colocaram em dúvida essa convicção. Constatou-se, com o tempo, que a reputação tem seus limites, razão pela qual se passou a defender que os auditores devem assumir responsabilidades em razão de trabalhos deficientes. Entretanto, como ressaltado por Michael $\mathrm{Raab}^{41}$, não há como deixar de notar que se a responsabilidade atribuída a estes entes for excessiva, os serviços por eles prestados ficarão tão dispendiosos que acabará por inviabilizar economicamente sua atuação. A solução encontrada pelo autor, diante da necessidade de conciliar atuação eficaz do auditor independente, como auxiliar dos órgãos de controle, com custos adequados e razoáveis, é exigir que detecte fraudes somente diante da existência de "sinais de alerta" que demandem um maior aprofundamento nos documentos objeto de auditoria. Portanto, somente na presença de red flags é que deveria o auditor realizar procedimentos específicos que permitam desvendar eventual fraude, sob pena de ser responsabilizado pela deficiência. (Grifos desta autora)

11. Dentro desse contexto, a própria legislação, como não poderia deixar de ser, não exige que sociedades de auditoria desçam a minúcias, questionando todas as informações apresentadas pelas sociedades auditadas, em qualquer hipótese. Porém, situações específicas podem demandar um aprofundamento na análise dos elementos apresentados, não havendo como ser sustentada, nestas hipóteses, defesa pautada exclusivamente na confiança depositada no cliente que está sendo auditado. Diante da existência de um sinal de alerta, surge para o gatekeeper a obrigação de melhor investigar o suporte que embasa o documento que está sendo analisado. E a investigação não deve se limitar a questionar o auditado sobre a veracidade das informações, ou mesmo obter uma Carta de Responsabilidade, mas sim realizar uma auditoria cujo escopo seja verificar se os documentos estão devidamente embasados (Grifo desta autora).

Nos excertos citados, menciona-se a função de Gatekeeper, função essa que está relacionada com o papel de um intermediário informacional. $\mathrm{O}$ auditor, por estar dentro das companhias auditadas, executando os trabalhos de forma independente, para cumprir com seus objetivos profissionais, tem acesso a mais informações sobre as práticas contábeis, e se elas estão de acordo com as normas aplicáveis que os demais participantes do mercado, como os

\footnotetext{
${ }^{39}$ COASE, Ronald H. The Nature of the Firm. 4 Economica 386, 394-395 (1937);

${ }^{40}$ Estes custos são incluídos nos chamados "agency costs";

${ }^{41}$ RAAB, Michael S. Detecting and Preventing Financial Statement Fraud: The Roles of the Reporting Company and the Independent Auditor. 5 Yale L. \& Pol'y Rev. 514 (1986-1987);
} 
investidores. Posteriormente é discutida a responsabilidade ante as fraudes, inclusive mencionase a relação de custo-benefício de uma auditoria que tenha como objetivo a detecção de fraude. O foco principal da argumentação é a investigação, por parte do auditor, em casos de fraudes relevantes para as demonstrações financeiras.

Esse foi o caso que mais explorou as funções e responsabilidade do auditor, no qual foi explicitado o conhecimento das discussões acerca do tema pelos envolvidos. Com base nos argumentos e discussões acima, não foi identificada existência do AEG de razoabilidade nesse acórdão.

\subsection{Discussão dos resultados}

\subsubsection{Processos cíveis e administrativos}

Para auxiliar na organização e análise dos acórdãos, foi utilizado o software Nvivo®. Para análise apropriada dos documentos em questão, foi feita uma divisão dos trechos identificados nos acórdãos com base nas seguintes categorias: (i) Fraude, (ii) Continuidade, (iii) Outros/Procedimentos e (iv) Outros - Não divulgação de informação relevante.

Após essa categorização, efetuou-se uma análise dos trechos do processo que se enquadravam nessa classificação. Aqui é importante mencionar que mesmo que o processo seja referente a uma acusação relacionada à fraude ou continuidade, podem ser encontrados nos documentos analisados trechos ou argumentos referentes a outras temáticas ou categorizações, como, por exemplo, o desempenho do auditor. As figuras a seguir relacionam os acórdãos dos processos com as categorizações definidas para este trabalho. 
Figura 7 - Menções à fraude - responsabilidade do auditor

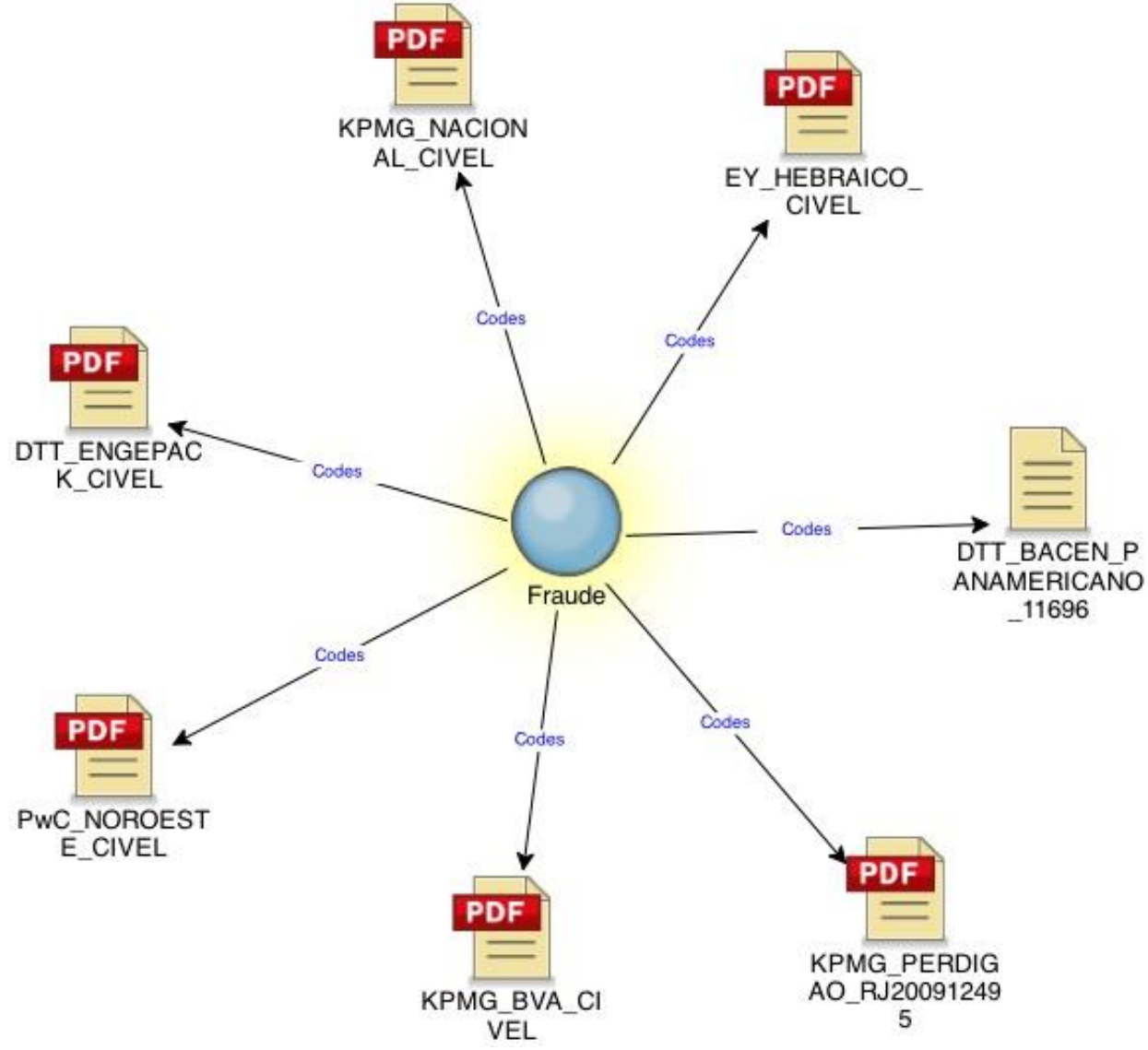

Fonte: Elaborada por esta autora. 
Figura 8 - Menções à continuidade - responsabilidade do auditor

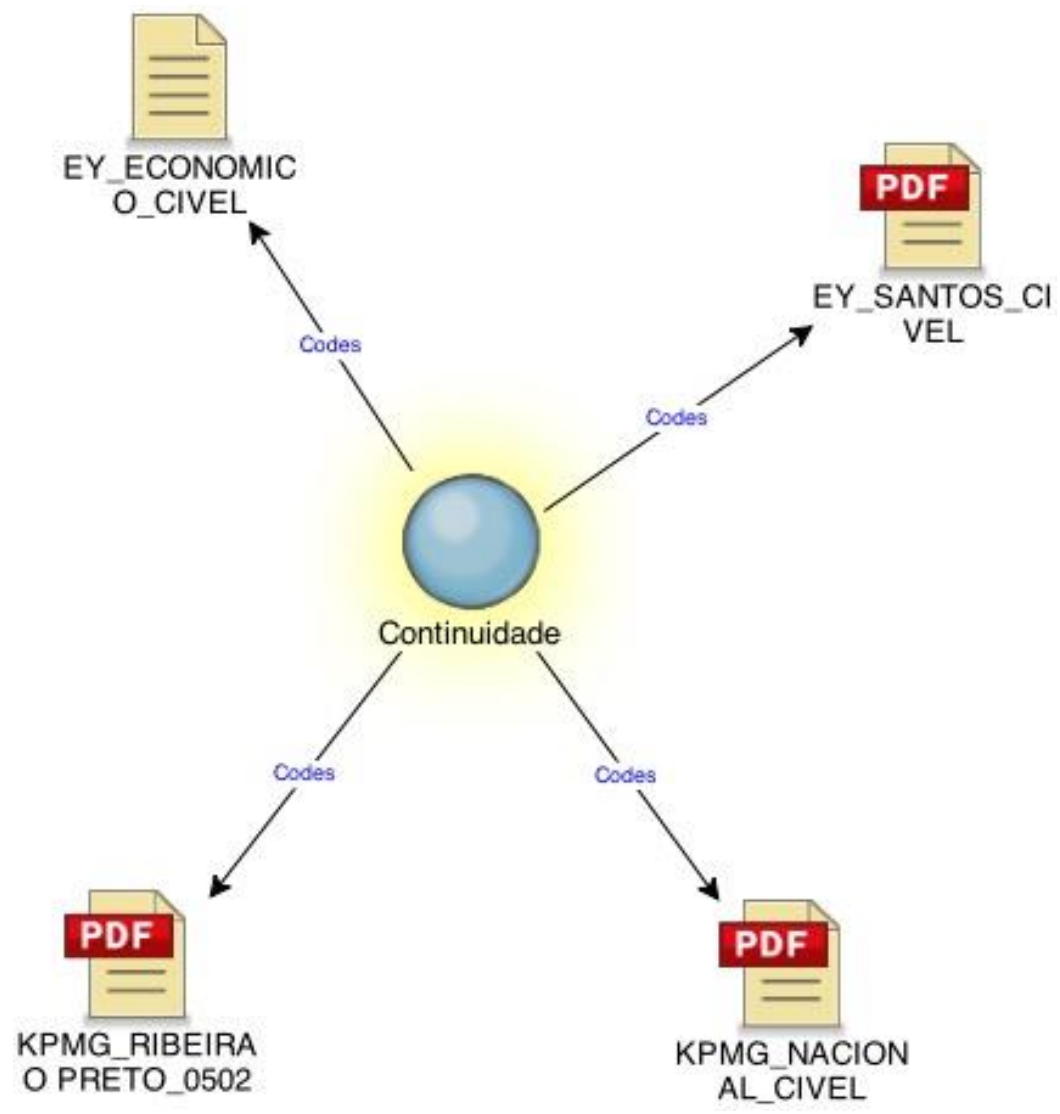

Fonte: Elaborada por esta autora.

Com base na Figura 7, nota-se que os seguintes processos mencionaram fraude como uma das responsabilidades do auditor, mesmo que a acusação do caso não tivesse a fraude como argumento principal: (i) Banco Noroeste (Cível), (ii) Engepack (Cível), (iii) Sociedade Hebraico Brasileira (Cível), (iv) BVA (Cível), (v) Banco Nacional (cível), (vi) Panamericano (Bacen) e (vii) Perdigão (CVM).

Com relação à Figura 8, a questão de divulgação de informações sobre os problemas de continuidade das companhias aparece nos seguintes casos: (i) Banco Santos (Cível), (ii) Banco Econômico (Cível), (iii) Ribeirão Preto Water Park (CVM), (iv) Banco Nacional (Cível). No caso do Banco Nacional, foram analisados 4 acórdãos, relacionados ao mesmo tema: continuidade. Apenas para um dos casos, considerou-se também a menção a fraude como responsabilidade do auditor.

As menções feitas a responsabilidades dos auditores sobre fraudes são mais frequentes quando comparadas a responsabilidades relacionadas à continuidade (Figura 9). 
Figura 9 - Comparação de menções à Fraude e à Continuidade

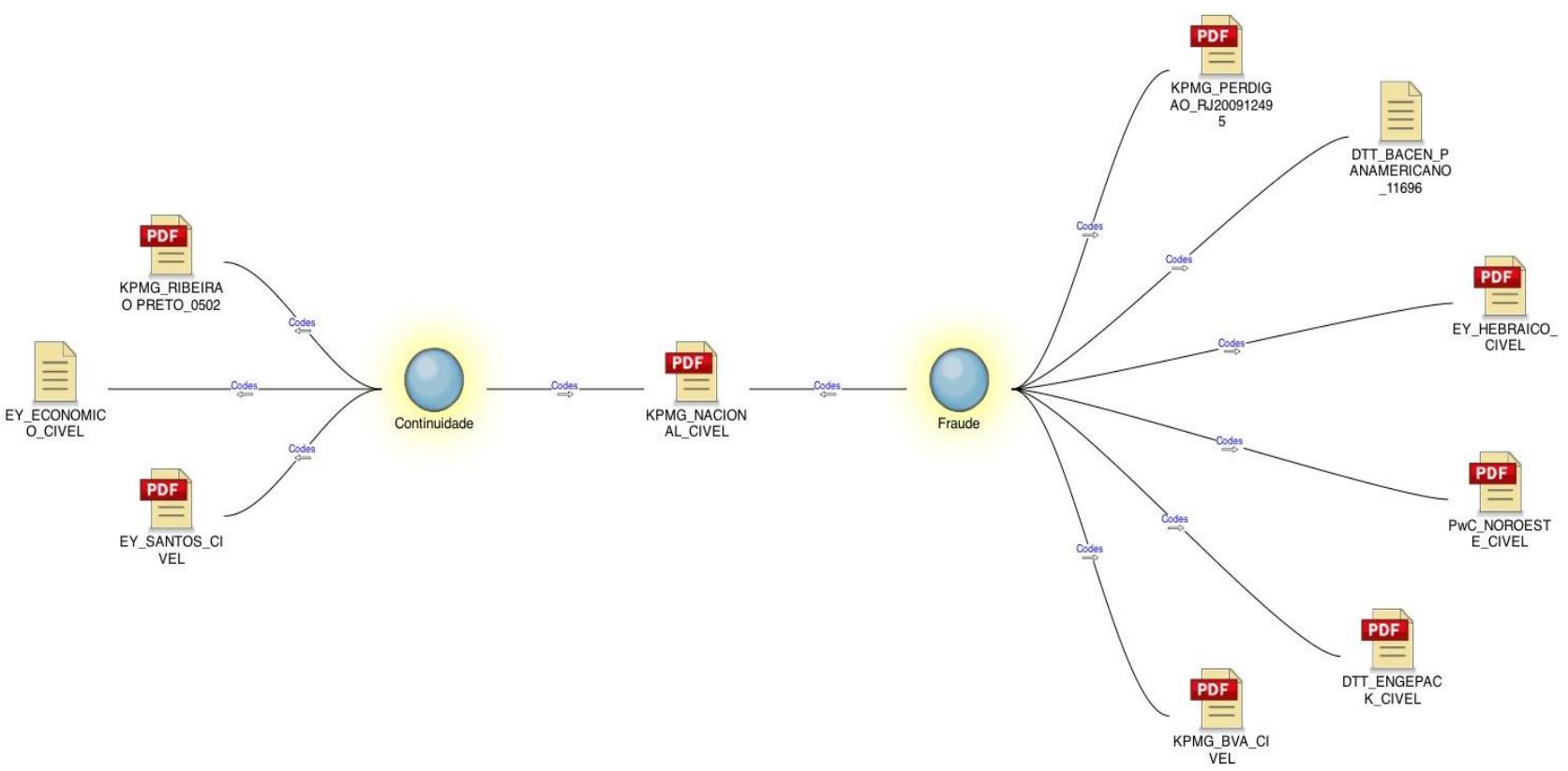

Fonte: Elaborada por esta autora.

Figura 10 - Menções à não divulgação de fatos relevantes - responsabilidade do auditor

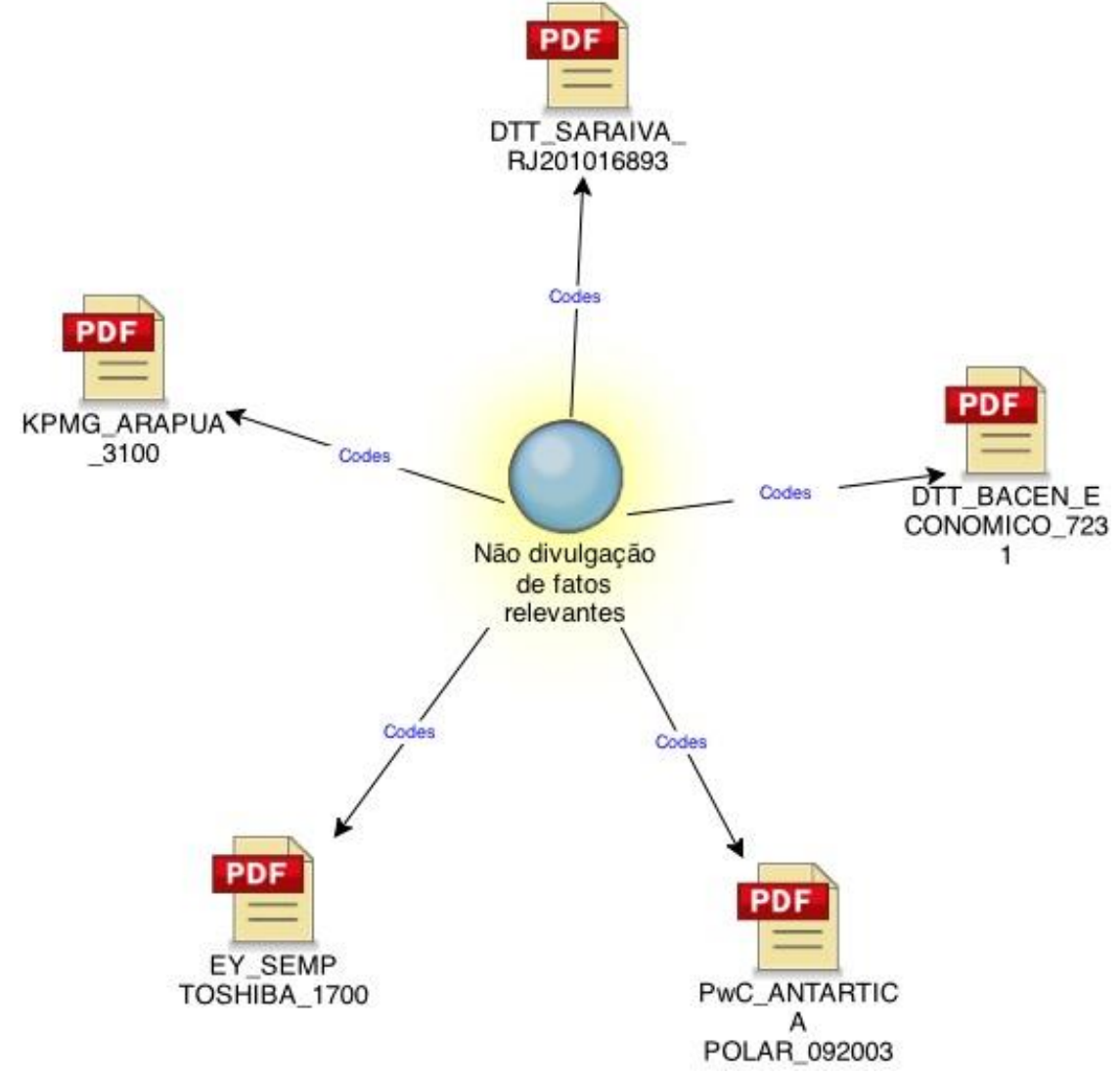

Fonte: Elaborada por esta autora. 
Figura 11 - Menções a outros temas técnicos - responsabilidade do auditor

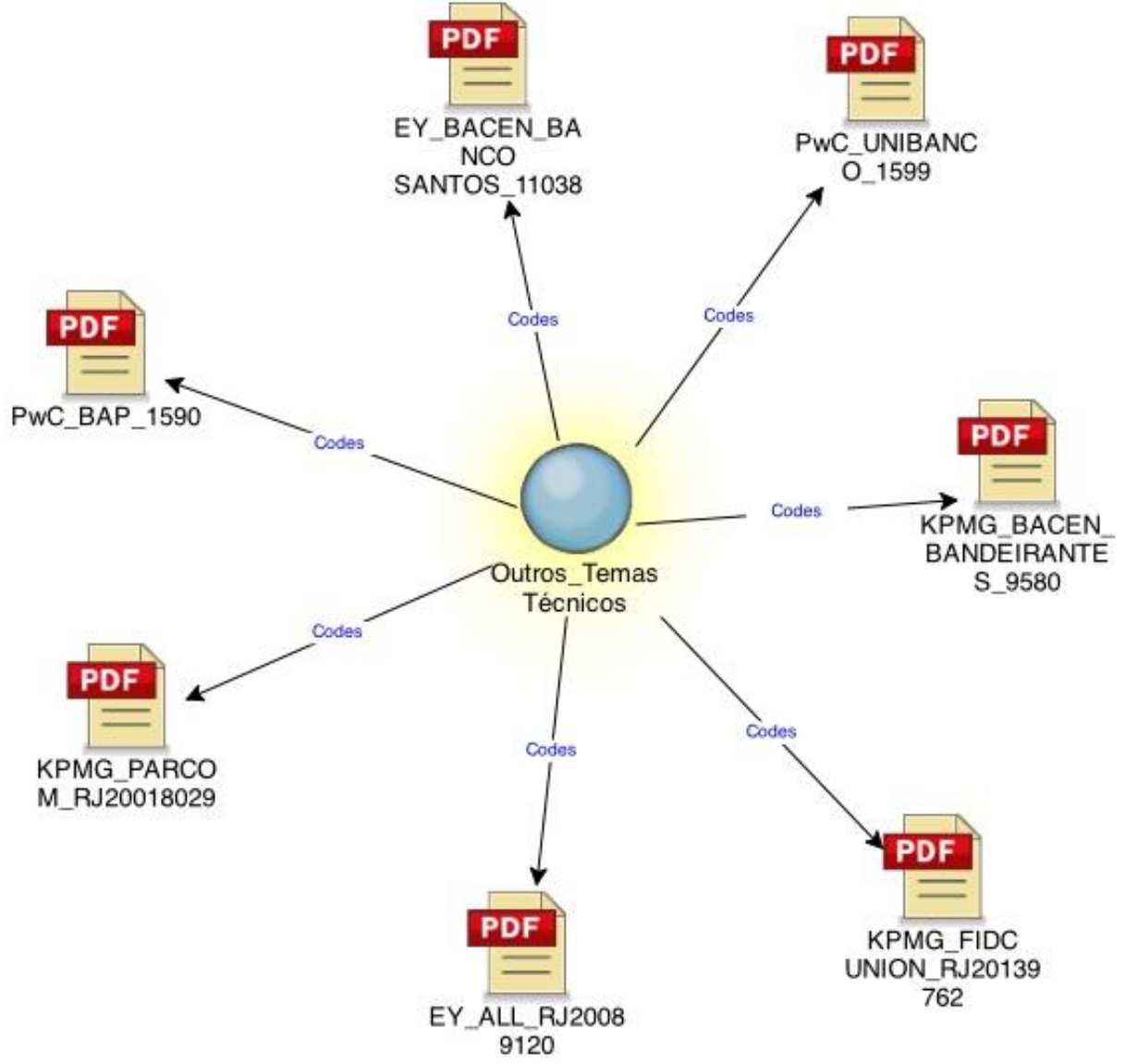

Fonte: Elaborada por esta autora.

Além das acusações relacionadas às responsabilidades sobre 'fraude' e 'continuidade', outras duas categorias consideradas para o estudo foram 'fatos relevantes não divulgados pelo auditor' e 'outros temas técnicos', objetos das Figuras 10 e 11 respectivamente.

Após a identificação dos trechos que discutem a responsabilidade do auditor, as categorizações e a análise de cada acórdão, as tabelas a seguir resumem os achados dessa pesquisa: 
Tabela 13 - Acórdãos de processos cíveis - análises

\begin{tabular}{|c|c|c|c|c|c|}
\hline & Número do Processo & Auditor & Companhia & $\begin{array}{l}\text { Categoria } \\
\text { assunto }\end{array}$ & Conclusão \\
\hline 1 & $\begin{array}{l}2017526- \\
58.2014 .8 .26 .0000\end{array}$ & DTT & Engepack & Fraude & $\begin{array}{c}\text { AEG não } \\
\text { identificado }\end{array}$ \\
\hline 2 & $\begin{array}{l}\text { Apl. 9161946- } \\
\text { 23.2003.8.26.0000 }\end{array}$ & $\mathrm{PwC}$ & Banco Noroeste & Fraude & $\begin{array}{c}\text { Gap } \\
\text { Razoabilidade }\end{array}$ \\
\hline 3 & $\begin{array}{l}\text { 0123784- } \\
98.2006 .8 .26 .0100\end{array}$ & $\mathrm{E} \& \mathrm{Y}$ & Banco Santos & Continuidade & $\begin{array}{l}\text { AEG não } \\
\text { identificado }\end{array}$ \\
\hline 4 & $\begin{array}{l}\text { 1028724- } \\
03.2014 .8 .26 .0100\end{array}$ & $\mathrm{E} \& \mathrm{Y}$ & $\begin{array}{l}\text { Sociedade } \\
\text { Hebraico } \\
\text { Brasileira } \\
\text { Renascença }\end{array}$ & Fraude & $\begin{array}{l}\text { AEG não } \\
\text { identificado }\end{array}$ \\
\hline 5 & $\begin{array}{l}0002074- \\
13.2001 .4 .01 .3400 \\
\text { (velha -: } \\
\text { 2001.34.00.002072- } \\
0 \text { ) }\end{array}$ & $\mathrm{E} \& \mathrm{Y}$ & Banco Econômico & Continuidade & $\begin{array}{l}\text { AEG não } \\
\text { identificado }\end{array}$ \\
\hline 6 & $\begin{array}{l}\text { 2103824- } \\
\text { 53.2014.8.26.0000 }\end{array}$ & KPMG & Banco BVA & Fraude & $\begin{array}{c}\text { Gap } \\
\text { Razoabilidade }\end{array}$ \\
\hline 7 & $\begin{array}{l}2212188- \\
22.2014 .8 .26 .0000\end{array}$ & KPMG & Basf & $\begin{array}{c}\text { Outros - } \\
\text { Procedimentos }\end{array}$ & $\begin{array}{c}\text { AEG não } \\
\text { identificado }\end{array}$ \\
\hline 8 & $\begin{array}{l}\text { AREsp n }{ }^{\circ} 98643 \text { / SP } \\
(2011 / 0198292-8)\end{array}$ & KPMG & Banco Nacional & Continuidade & $\begin{array}{c}\text { AEG não } \\
\text { identificado }\end{array}$ \\
\hline 9 & $\begin{array}{l}\text { AREsp n }{ }^{\circ} 88568 \text { / } \\
\text { SP(2011/0197588-5) }\end{array}$ & KPMG & Banco Nacional & $\begin{array}{c}\text { Fraude/ } \\
\text { Continuidade }\end{array}$ & $\begin{array}{c}\text { Gap } \\
\text { Razoabilidade }\end{array}$ \\
\hline 10 & $\begin{array}{l}\text { AREsp no } 140538 \text { / } \\
\text { DF(2012/0040106-7) }\end{array}$ & KPMG & Banco Nacional & Continuidade & $\begin{array}{c}\text { Gap } \\
\text { Razoabilidade }\end{array}$ \\
\hline 11 & $\begin{array}{l}\text { REsp n } n^{\circ} 1283737 \text { / } \\
\text { DF(2011/0223035-6) }\end{array}$ & KPMG & Banco Nacional & Continuidade & $\begin{array}{c}\text { AEG não } \\
\text { identificado }\end{array}$ \\
\hline
\end{tabular}

Fonte: Elaborada por esta autora.

Para os processos cíveis, foram identificados AEG de expectativas não razoáveis em 4 (quatro) casos de um total de 11 (onze), o que representa 36\% da amostra de processos cíveis. Adicionalmente, é importante observar que problemas relacionados à fraude e à continuidade são os assuntos mais recorrentes no que tange a responsabilidades do auditor na esfera cível. Na Figura 12 é possível visualizar a representatividade desses assuntos. O item 'continuidade' representa um pouco mais de $46 \%$ dos casos analisados, pois para um caso especificamente, do Banco Nacional, o assunto de continuidade também foi considerado em conjunto com o assunto de fraude nas argumentações dos processos. 


\section{Figura 12 - Assuntos em processos cíveis (valores percentuais)}

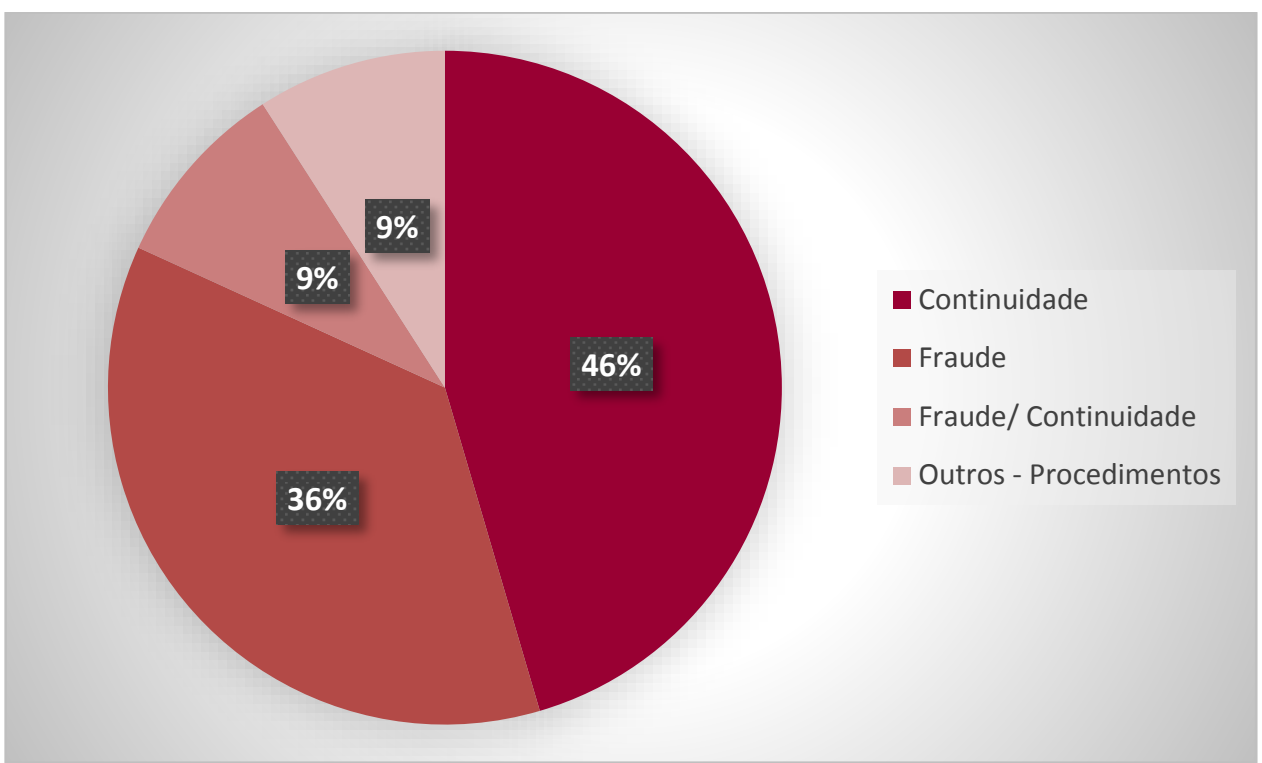

Fonte: Elaborada por esta autora.

Tabela 14 - Acórdãos de processos administrativos - CVM - análises

\begin{tabular}{|c|c|c|c|c|c|c|}
\hline & Processo & Decisão & Auditor & Companhia & $\begin{array}{c}\text { Categoria } \\
\text { assunto }\end{array}$ & Conclusão \\
\hline 1 & RJ2010/16893 & $\begin{array}{l}\text { Colegiado } \\
\text { CVM }\end{array}$ & DTT & $\begin{array}{l}\text { Saraiva S/A - } \\
\text { Livreiros } \\
\text { Editores }\end{array}$ & $\begin{array}{l}\text { Outros - Não } \\
\text { divulgação de } \\
\text { informação } \\
\text { relevante }\end{array}$ & $\begin{array}{l}\text { AEG não } \\
\text { identificado }\end{array}$ \\
\hline 2 & 2010-16893 & CRSFN & DTT & $\begin{array}{l}\text { Saraiva S/A - } \\
\text { Livreiros } \\
\text { Editores }\end{array}$ & $\begin{array}{l}\text { Outros - Não } \\
\text { divulgação de } \\
\text { informação } \\
\text { relevante }\end{array}$ & $\begin{array}{l}\text { AEG não } \\
\text { identificado }\end{array}$ \\
\hline 3 & $17 / 00$ & $\begin{array}{l}\text { Colegiado } \\
\text { CVM }\end{array}$ & $\mathrm{E} \& \mathrm{Y}$ & $\begin{array}{l}\text { Semp Toshiba } \\
\text { S/A, }\end{array}$ & $\begin{array}{l}\text { Outros - Não } \\
\text { divulgação de } \\
\text { informação } \\
\text { relevante }\end{array}$ & $\begin{array}{c}\text { Gap } \\
\text { Razoabilidade }\end{array}$ \\
\hline 4 & IA $2000-17$ & CRSFN & $\mathrm{E} \& \mathrm{Y}$ & $\begin{array}{l}\text { Semp Toshiba } \\
\text { S/A }\end{array}$ & $\begin{array}{l}\text { Outros - Não } \\
\text { divulgação de } \\
\text { informação } \\
\text { relevante }\end{array}$ & $\begin{array}{l}\text { AEG não } \\
\text { identificado }\end{array}$ \\
\hline 5 & RJ2008/9120 & $\begin{array}{l}\text { Colegiado } \\
\text { CVM }\end{array}$ & $\mathrm{E} \& \mathrm{Y}$ & $\begin{array}{l}\text { All - América } \\
\text { Latina } \\
\text { Logística S/A }\end{array}$ & $\begin{array}{c}\text { Outros - } \\
\text { Procedimentos }\end{array}$ & $\begin{array}{c}\text { Gap } \\
\text { Razoabilidade }\end{array}$ \\
\hline 6 & RJ2008/9120 & CRSFN & $\mathrm{E} \& \mathrm{Y}$ & $\begin{array}{l}\text { All - América } \\
\text { Latina } \\
\text { Logística S/A }\end{array}$ & $\begin{array}{c}\text { Outros - } \\
\text { Procedimentos }\end{array}$ & $\begin{array}{c}\text { Gap } \\
\text { Razoabilidade }\end{array}$ \\
\hline
\end{tabular}




\begin{tabular}{|c|c|c|c|c|c|c|}
\hline & Processo & Decisão & Auditor & Companhia & $\begin{array}{c}\text { Categoria } \\
\text { assunto }\end{array}$ & Conclusão \\
\hline 7 & $15 / 99$ & $\begin{array}{l}\text { Colegiado } \\
\text { CVM }\end{array}$ & $\mathrm{PwC}$ & $\begin{array}{l}\text { Fundos } \\
\text { Administrados } \\
\text { pelo Unibanco }\end{array}$ & $\begin{array}{c}\text { Outros - } \\
\text { Procedimentos }\end{array}$ & $\begin{array}{l}\text { AEG não } \\
\text { identificado }\end{array}$ \\
\hline 8 & $15 / 99$ & CRSFN & $\mathrm{PwC}$ & $\begin{array}{l}\text { Fundos } \\
\text { Administrados } \\
\text { pelo Unibanco }\end{array}$ & $\begin{array}{c}\text { Outros - } \\
\text { Procedimentos }\end{array}$ & $\begin{array}{l}\text { AEG não } \\
\text { identificado }\end{array}$ \\
\hline 9 & $09 / 03$ & $\begin{array}{l}\text { Colegiado } \\
\text { CVM }\end{array}$ & $\mathrm{PwC}$ & $\begin{array}{l}\text { Bebidas } \\
\text { Antarctica } \\
\text { Polar S/A, }\end{array}$ & $\begin{array}{c}\text { Outros - Não } \\
\text { divulgação de } \\
\text { informação } \\
\text { relevante }\end{array}$ & $\begin{array}{l}\text { AEG não } \\
\text { identificado }\end{array}$ \\
\hline 10 & 09/03 & CRSFN & $\mathrm{PwC}$ & $\begin{array}{l}\text { Bebidas } \\
\text { Antarctica } \\
\text { Polar S/A, }\end{array}$ & $\begin{array}{c}\text { Outros - Não } \\
\text { divulgação de } \\
\text { informação } \\
\text { relevante }\end{array}$ & $\begin{array}{l}\text { AEG não } \\
\text { identificado }\end{array}$ \\
\hline 11 & $15 / 90$ & $\begin{array}{l}\text { Colegiado } \\
\text { CVM }\end{array}$ & $\mathrm{PwC}$ & $\begin{array}{l}\text { Barretto de } \\
\text { Araújo } \\
\text { Produtos de } \\
\text { Cacau S.A. }\end{array}$ & $\begin{array}{c}\text { Outros - } \\
\text { Procedimentos }\end{array}$ & $\begin{array}{l}\text { AEG não } \\
\text { identificado }\end{array}$ \\
\hline 12 & $15 / 1990$ & CRSFN & $\mathrm{PwC}$ & $\begin{array}{l}\text { Barretto de } \\
\text { Araújo } \\
\text { Produtos de } \\
\text { Cacau S.A. }\end{array}$ & $\begin{array}{c}\text { Outros - } \\
\text { Procedimentos }\end{array}$ & $\begin{array}{l}\text { AEG não } \\
\text { identificado }\end{array}$ \\
\hline 13 & RJ2001/8029 & $\begin{array}{l}\text { Colegiado } \\
\text { CVM }\end{array}$ & KPMG & $\begin{array}{l}\text { Parcom } \\
\text { Participações } \\
\text { S/A }\end{array}$ & $\begin{array}{c}\text { Outros - } \\
\text { Procedimentos }\end{array}$ & $\begin{array}{l}\text { AEG não } \\
\text { identificado }\end{array}$ \\
\hline 14 & $05 / 02$ & $\begin{array}{l}\text { Colegiado } \\
\text { CVM }\end{array}$ & KPMG & $\begin{array}{l}\text { Ribeirão Preto } \\
\text { Water Park } \\
\text { S/A }\end{array}$ & Continuidade & $\begin{array}{l}\text { AEG não } \\
\text { identificado }\end{array}$ \\
\hline 15 & RJ2009/12495 & $\begin{array}{l}\text { Colegiado } \\
\text { CVM }\end{array}$ & KPMG & $\begin{array}{l}\text { Perdigão S/A, } \\
\text { atual BRF - } \\
\text { Brasil Foods } \\
\text { S/A }\end{array}$ & Fraude & $\begin{array}{c}\text { Gap } \\
\text { Razoabilidade }\end{array}$ \\
\hline 16 & RJ2009/12495 & CRSFN & KPMG & $\begin{array}{l}\text { Perdigão S/A, } \\
\text { atual BRF - } \\
\text { Brasil Foods } \\
\text { S/A }\end{array}$ & Fraude & $\begin{array}{l}\text { AEG não } \\
\text { identificado }\end{array}$ \\
\hline 17 & $31 / 00$ & $\begin{array}{l}\text { Colegiado } \\
\text { CVM }\end{array}$ & KPMG & $\begin{array}{l}\text { Lojas Arapuã } \\
\text { S/A }\end{array}$ & $\begin{array}{c}\text { Outros - Não } \\
\text { divulgação de } \\
\text { informação } \\
\text { relevante }\end{array}$ & $\begin{array}{l}\text { AEG não } \\
\text { identificado }\end{array}$ \\
\hline 18 & $31 / 00$ & CRSFN & KPMG & $\begin{array}{l}\text { Lojas Arapuã } \\
\text { S/A }\end{array}$ & $\begin{array}{c}\text { Outros - Não } \\
\text { divulgação de } \\
\text { informação } \\
\text { relevante }\end{array}$ & $\begin{array}{l}\text { AEG não } \\
\text { identificado }\end{array}$ \\
\hline 19 & RJ2013/9762 & $\begin{array}{l}\text { Colegiado } \\
\text { CVM }\end{array}$ & KPMG & FIDC Union & $\begin{array}{c}\text { Outros - } \\
\text { Procedimentos } \\
\end{array}$ & $\begin{array}{c}\text { AEG não } \\
\text { identificado }\end{array}$ \\
\hline
\end{tabular}

Fonte: Elaborada por esta autora.

Com relação aos processos administrativos da CVM, foram identificados 4 (quatro) casos de AEG de expectativas não razoáveis, de um total de 19 acórdãos analisados, o que representa 
$21 \%$ da população em questão. Para o caso da Semp Toshiba, o questionamento do processo refere à suficiência dos testes feitos pela auditoria especificamente sobre operações entre partes relacionadas e aspectos de gestão da empresa. No caso da All e da Perdigão, nota-se a tendência de considerar a opinião do auditor como um atestado de fidedignidade ou de uma garantia das demonstrações financeiras, sem explorar de forma adequada às funções e as responsabilidades do auditor.

A Figura 13 mostra os assuntos mais recorrentes no que tange aos principais assuntos nos quais os auditores independentes estão envolvidos, no caso dos processos administrativos da CVM. Nesse contexto, são mais representativos os processos nos quais são questionadas a suficiência de procedimentos feitos pelo auditor e a divulgação de informações relevantes da companhia no relatório do auditor do que os casos de fraude e continuidade. Isso guarda relação com as próprias funções do regulador, diferentemente do que acontece na esfera cível.

Figura 13 - Assuntos processos CVM (valores percentuais)

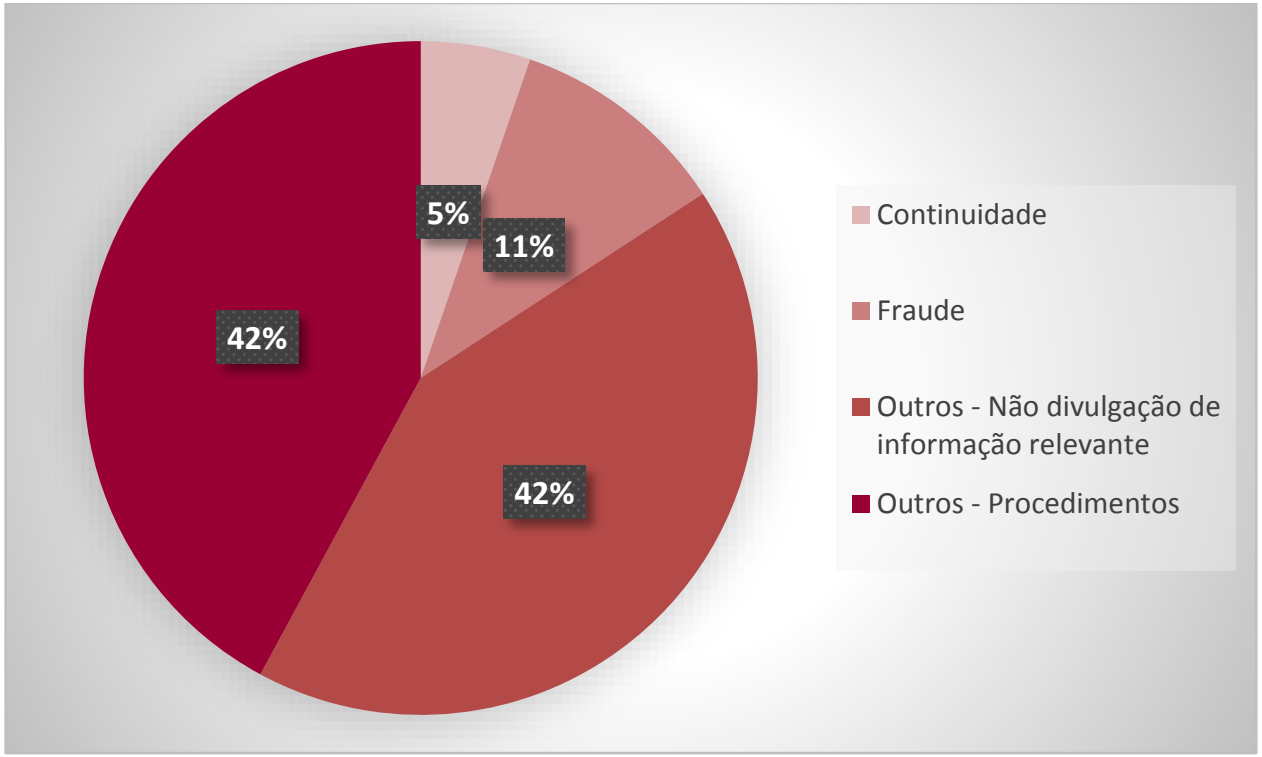

Fonte: Elaborada por esta autora.

Sobre o item 'Outros - Não divulgação de informação relevante' no gráfico, os assuntos que estão relacionados a ele referem-se a:

(i) $25 \%$ - não divulgação de realização de operações com derivativos,

(ii) $50 \%$ - não divulgação de relacionamentos entre partes relacionadas e 
(iii) $25 \%$ - não divulgação de contingências.

Sobre o item 'Outros - Procedimentos', os assuntos que estão relacionados a ele referem-se a:

(i) $25 \%$ - erro na avaliação de passivo,

(ii) $25 \%$ - atos irregulares na gestão de fundos,

(iii) $25 \%$ - desvio de objeto social e insuficiência de provisão para devedores duvidosos,

(iv) $13 \%$ - reavaliação de intagível, divulgação de operações de mútuos e ativação de despesa e

(v) $13 \%$ - insuficiência de provisão para devedores duvidosos

Em 'Outros - Procedimentos', é possível notar que o motivo mais recorrente das acusações é a falta de procedimentos para verificar a suficiência de provisão para devedores duvidosos e para a categoria de 'Outros - Não divulgação de informação relevante'é recorrente a insuficiência de divulgações sobre partes relacionadas.

Tabela 15 - Acórdãos de processos administrativos - Bacen - análises

\begin{tabular}{|c|c|c|c|c|c|}
\hline & Processo & Auditor & Companhia & $\begin{array}{l}\text { Categoria } \\
\text { assunto }\end{array}$ & Conclusão \\
\hline 1 & $\begin{array}{l}\text { Processo BCB } \\
0001046032\end{array}$ & DTT & $\begin{array}{l}\text { Banco Excel Econômico } \\
\text { S.A. }\end{array}$ & $\begin{array}{c}\text { Outros - Não } \\
\text { divulgação de } \\
\text { informação } \\
\text { relevante }\end{array}$ & $\begin{array}{c}\text { Gap } \\
\text { Razoabilidade }\end{array}$ \\
\hline 2 & $\begin{array}{l}\text { Processo BCB } \\
0501284933\end{array}$ & $E \& Y$ & Banco Santos S.A. & $\begin{array}{c}\text { Outros - } \\
\text { Procedimentos }\end{array}$ & $\begin{array}{c}\text { Gap } \\
\text { Razoabilidade }\end{array}$ \\
\hline 3 & $\begin{array}{l}\text { Processo BCB } \\
0201144611\end{array}$ & KPMG & Banco Bandeirantes & $\begin{array}{c}\text { Outros - } \\
\text { Procedimentos }\end{array}$ & $\begin{array}{c}\text { AEG não } \\
\text { identificado }\end{array}$ \\
\hline 4 & $\begin{array}{l}\text { Processo BCB } \\
1001494887\end{array}$ & DTT & $\begin{array}{l}\text { Banco Panamericano } \\
\text { S.A. }\end{array}$ & Fraude & $\begin{array}{c}\text { AEG não } \\
\text { identificado }\end{array}$ \\
\hline
\end{tabular}

Fonte: Elaborada por esta autora.

Com relação aos processos administrativos do Bacen, foram identificados AEG de razoabilidade em 2 (dois) casos. Isso corresponde a aproximadamente 50\% da população selecionada. Trata-se dos casos do Banco Excel Econômico e do Banco Santos. No primeiro caso tem-se a discussão de que a opinião do auditor serve como um atestado de fidedignidade da saúde financeira da empresa; no segundo caso, a discussão é sobre ser função do auditor a detecção de fraudes. 
De acordo com a Figura 14, assim como nos casos da CVM, os casos do Bacen relacionam-se mais frequentemente a questões da suficiência dos procedimentos de auditoria, o que também guarda relação com as funções de fiscalização desse regulador.

Figura 14 - Assuntos objeto dos processos Bacen (valores percentuais)

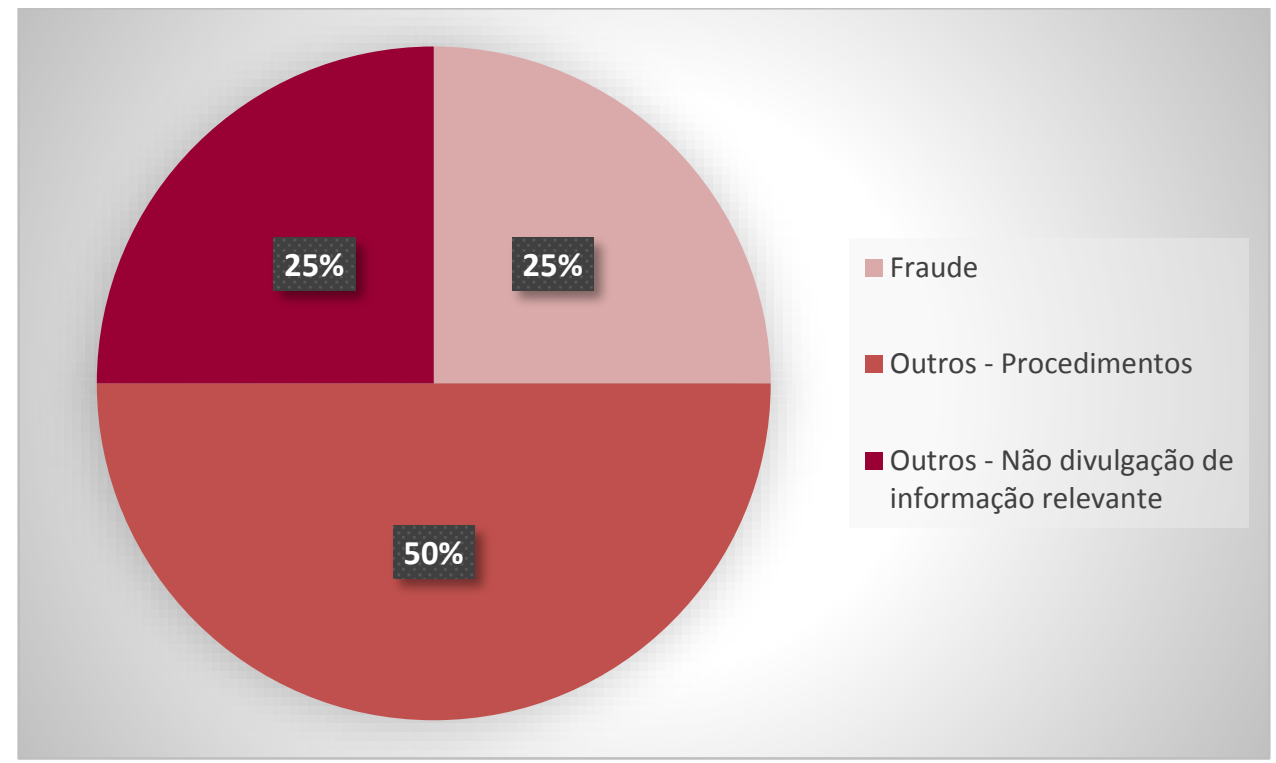

Fonte: Elaborada por esta autora.

Sobre a categoria 'Outros - Não divulgação de informação relevante', o caso em questão trata da ausência de divulgação de falta de liquidez de créditos. Já com relação aos 'Outros Procedimentos', tratam-se dos seguintes assuntos: (i) incremento artificial nos resultados e (ii) insuficiência de provisão para devedores duvidosos. Independente do fato do auditor ter sido acusado de não divulgar uma informação relevante ou não ter feito procedimentos de auditoria suficientes, os motivos mais recorrente, nesse regulador, com base na amostra analisada, é preocupação com a falta de liquidez de créditos e a consequente suficiência de provisão para devedores duvidosos.

Ao se considerar a totalidade dos processos analisados (34 (trinta e quatro)) há 10 (dez) casos de AEG de expectativas não razoáveis, o que representa $29 \%$ do total analisado, considerando as limitações da pesquisa. Embora esses processos não correspondam à maioria do total analisado, é importante destacar a sua existência na argumentação dos juízes responsáveis quando da formalização dos acórdãos. Isso denota que esses argumentos foram considerados no processo de julgamento, e que a existência do AEG de fato se materializa em determinadas circunstâncias. 
Outra consideração importante observada durante a análise dos processos é o fato de ter havido poucas menções, nos documentos de decisão, sobre a Carta de Representação da administração. Este documento, que delimita as resposabilidades dos participantes do contrato, no caso administração da empresa auditada e auditores, foi mencionado apenas pela defesa das firmas de auditoria nos acórdão do Banco Santos (Bacen) e Perdigão (CVM) e nos argumentos do voto apenas no caso do Banco Panamericano. Esse fato também é um argumento de que talvez a Carta de Representação não esteja sendo discutida no âmbito do julgamento o que também contribui para o aumento do AEG.

Vale lembrar que o propósito desta pesquisa não é questionar a decisão dos juízes com relação aos processos analisados, mas analisar os argumentos presentes nos acórdãos e se eles denotam a existência de AEG. Também não é o propósito da pesquisa relacionar a decisão do processo com a existência ou não de AEG de razoabilidade, uma vez que a responsabilidade do auditor pode não ser o mérito que está sendo discutido. Pode ter havido, por exemplo, alguma discussão no sentido de contextualizar o mérito.

\subsubsection{AEG de razoabilidade - Discussão e endereçamento}

As conclusões deste trabalho estão em linha com os achados internacionais no que tange à existência de AEG. O trabalho também converge com os achados de Lowe (1994), Lowe, Smith e Frank (2001) e Reckers, Jennings, Lowe e Kurt (2007), que concluíram haver uma significativa divergência de percepções, entre juízes, auditores e estudantes com relação às expectativas sobre a atividade do auditor.

Lowe (1994) destacou como os principais pontos de diferenças de expectativas, especificamente a respeito das responsabilidades do auditor: (i) responsabilidade primária sobre as demonstrações financeiras, (ii) responsabilidade sobre detecção de fraudes, mesmo que de pequenos valores, (iii) funções de 'segurador' contra perdas para os acionistas e (iv) função de 'public watchdog'.

Sem dúvida, esses elementos apontados por Lowe (1994) também foram identificados na presente pesquisa. Interessante mencionar que as questões de responsabilidade sobre fraudes e sobre problemas de continuidade operacional das empresas auditadas foram mais frequentes nos processos cíveis do que nos administrativos. Já, nesses últimos, são mais frequentes os assuntos relacionados aos procedimentos do auditor. 
De acordo com Porter (1990), algumas das atribuições que são consideradas do auditor independente, e por isso ocasionam no AEG de expectativas não razoáveis, são: (i) garantir que a companhia é solvente; (ii) detectar e informar atos ilícitos que não estejam relacionados com a contabilidade da companhia; (iii) avaliar a eficiência e efetividade da administração da companhia auditada, entre outros.

No caso do presente estudo, constatou-se que a existência de AEG de expectativas não razoáveis tem maior representatividade no caso dos processos cíveis. A maior parte do AEG identificado relaciona-se com responsabilidades sobre a detecção de fraudes. No entanto, foi observado, também, um caso relacionado a expectativas de procedimentos que devem ser executados pelos auditores, como, nesse caso, opinar sobre a gestão da companhia.

A responsabilidade dos auditores sobre a detecção de fraudes é um assunto amplamente discutido pelos contadores. O Ibracon, por exemplo, na $4^{\text {a }}$ Conferência Brasileira de Contabilidade e Auditoria Independente, organizou um debate sobre a responsabilidade civil desses profissionais. Dentre os participantes, o advogado Luiz Leonardo Cantidiano afirmou que a "responsabilidade do auditor independente que não tenha identificado situações adversas à entidade auditada é de caráter subjetivo: só é estabelecida após a comprovação da culpa e com a demonstração de que o prejuízo alegado decorreu de negligência ou imperícia do auditor" (IBRACON, 2014, p. 13).

Uma das questões mais polêmicas desse debate foi a consideração do promotor Eronides Aparecido Rodrigues dos Santos, que mencionou as doutrinas de responsabilidade civil objetiva e subjetiva que poderiam ser aplicadas aos auditores. Ainda, segundo o promotor, "Do ponto de vista legal, como fica a responsabilidade do auditor: ela depende da demonstração de culpa, é objetiva ou deve ser presumida? Esses são os aspectos que devemos debater para chegarmos a uma decisão que traga segurança jurídica a todos" (IBRACON, 2014, p. 13). Na responsabilidade subjetiva, o ônus da prova é da vítima, o que eleva os custos e atrasa demais o processo, com risco de não haver punição. Já, na responsabilidade objetiva, não é necessária produzir prova, e o réu é obrigado automaticamente a indenizar (IBRACON, 2014).

Ainda segundo o promotor, há uma possibilidade de se adotar uma via alternativa, que é a responsabilidade civil objetiva, com presunção de culpa, no caso dos processos contra os auditores. Essa é uma orientação que está sendo aplicada nos casos do Superior Tribunal de Justiça com relação a responsabilidades dos controladores e administradores de instituições 
financeiras. Nesse caso, há "responsabilização civil com inversão do ônus da prova" (IBRACON, 2014, p. 14).

Sem dúvida, optar por esse caminho deixaria o processo ainda mais oneroso e de acordo com o advogado Sérgio Bruno Varella, também presente no debate, "a presunção da culpa coloca o auditor como réu na mesma ação contra o gestor, sujeito igualmente a arresto de bens e bloqueio de contas. Portanto é uma situação insustentável para as auditorias" (IBRACON, 2014, p. 14).

Sobre esse assunto, em entrevista para esta pesquisa, o advogado Luiz Leonardo Cantidiano mencionou que tem a percepção de que o grande problema de entendimento das funções da auditoria está no judiciário e no Ministério Público. Com relação ao depoimento do promotor mencionado, ele diz que nota "uma exacerbação na atuação punitiva no judiciário de querer pegar todo mundo".

E complementa sobre o fato da responsabilidade civil objetiva com presunção de culpa:

É uma inversão até do que é o processo legal. Eu acusar sem prova para que o sujeito se defenda. Então eu acho que não há essa questão. Acho que o profissional do direito público entende o que é, mas essa exacerbação, como eu disse, da atuação punitiva, leva a isso, generaliza e pune todo mundo.

Pelo presente estudo, nota-se, portanto, no que tange à identificação de AEG de razoabilidade no Brasil, os achados estão em consonância com as pesquisas internacionais. A contribuição deste estudo é relevante uma vez que identifica a existência dessas divergências sobre a atividade do auditor independente, e isso pode levar a consequências materiais não apenas para as firmas de auditoria, mas também para o Sistema Financeiro Nacional e setor empresarial em geral. A conclusão deste estudo pretende, portanto, trazer mais informações sob esse prisma e contribuir para o processo de regulação do mercado brasileiro.

De acordo com Porter (1990), como o gap de razoabilidade é derivado principalmente da falta de conhecimento sobre o trabalho da auditoria, o endereçamento dessa questão seria mais eficiente se fossem melhoradas a comunicação e a educação sobre o tema. Sem dúvida isso também é aplicável para a realidade brasileira.

Uma das iniciativas tomadas pela própria classe dos auditores e contadores na tentativa de melhoria de comunicação foi a proposta do novo relatório do auditor pelo IAASB e, consequentemente, pelos nossos reguladores locais (CFC e Ibracon). 
No documento que formaliza algumas discussões sobre o novo normativo, Basis for Conclusion (IAASB, 2015, p. 8), é mencionada a intenção de maior transparência e redução do gap de expectativas:

13. O Grupo de Monitoramento (GM) geralmente vem apoiando o IAASB na busca de melhorias para o relatório de auditoria em resposta à demanda dos usuários por maior transparência na auditoria, observando que o aprimoramento do relatório do auditor deve reduzir os gaps de expectativas sobre a auditoria e auxiliar na restauração da confiança do mercado. Foi especificamente notado que o aumento da transparência pode aumentar a qualidade da auditoria, como enfoque adicional em matérias que ao serem reportadas podem indiretamente resultar em aumento no ceticismo profissional e atenção adicional por parte do auditor sobre os riscos significativos de auditoria $^{42}$ (tradução livre desta autora).

Uma das intenções do novo modelo é deixar claras as responsabilidades do auditor e da administração, além de trazer mais informações sobre a auditoria da empresa auditada (KeyAudit-Matters). Quanto à apresentação das informações (Oliveira, 2015, p. 94):

O novo relatório inicia-se com a opinião do auditor em relação à adequação das demonstrações contábeis e, posteriormente, apresenta para o usuário todas as justificativas que respaldaram a emissão final do auditor: a começar pelo escopo de auditoria, depois a materialidade utilizada, trabalhos realizados para os principais riscos que podem levar a distorções relevantes das demonstrações contábeis, como esses riscos foram endereçados, os principais findings identificados durante os trabalhos de auditoria, e como a Administração / Diretoria deve buscar um plano de ação, diante dos pontos de melhorias identificados.

Ainda de acordo com o IAASB, o novo relatório tem intenção de (i) reforçar a comunicação entre os auditores, investidores e responsáveis pela governança corporativa, (ii) aumentar a confiança dos usuários nos relatórios do auditor, (iii) aumentar a transparência e qualidade da auditoria e (iv) aumentar o interesse do público nos relatórios financeiros.

Sem dúvida, as propostas de alterações nas comunicações dos auditores podem trazer benefícios para o entendimento de seu trabalho. Além desse fator, a educação e o entendimento sobre o funcionamento do mercado de capitais também exercem uma influência importante, principalmente quando se trata da formação de profissionais que vão atuar nesse mercado, como é o caso dos profissionais de direito.

\footnotetext{
42 "MG members generally supported the IAASB in pursuing improvements to the auditor's report in response to users' demands for more transparency about the audit, noting that enhanced auditor reporting should reduce the information and expectations gaps about the audit and will be helpful in restoring market confidence. It was specifically noted that increased transparency might improve audit quality, as additional focus on matters to be reported could indirectly result in an increase in professional skepticism and additional attention by the auditor on significant audit risks".
} 
A regulação da atividade do auditor está em constante aprimoramento, e cabe aos profissionais envolvidos com esse tema acompanharem também o desenvolvimento e estabelecimento dessas mudanças. A questão da responsabilidade do auditor com relação à detecção de fraudes é um assunto amplamente discutido nos últimos anos, e notaram-se raras menções a esses fatos nos documentos e decisões judiciais analisados. Sem dúvida é importante conhecer o arcabouço legal que envolve uma discussão, mas aprofundar o conhecimento sobre as discussões dos órgãos de classe pode trazer benefícios e informações mais próximas à realidade dos fatos e auxiliar no processo de julgamento desses casos. Como sugestão deste trabalho, para auxiliar na melhoria desse processo, o Ibracon poderia disponibilizar mais materiais educativos sobre as principais discussões relacionadas as responsabilidades do auditor.

Além da melhoria na comunicação dos auditores, outras questões mais específicas podem auxiliar no direcionamento do AEG, conforme está demonstrado na seção 4.4.3 - Julgamentos CVM, adiante explanada.

Há de se considerar a existência de um contraponto sobre essas discussões, principalmente no sistema jurídico brasileiro, o que ocasiona o AEG de razoabilidade. O profissional Pedro Marcílio, ex-Diretor da CVM, menciona a constante tentativa dos auditores de não assumirem as responsabilidades sobre fraude, por exemplo. De acordo com o entrevistado, "só se tem importância no mercado quando se tem responsabilidade. Se não tem responsabilidade nenhuma, é irrelevante".

\subsubsection{Julgamentos CVM}

Como parte deste trabalho, foram realizadas entrevistas com ex-membros do Colegiado da CVM. Essa seleção foi considerada devido à relevância dos processos para essa pesquisa: $56 \%$ dos acórdãos analisados foram proveninentes da CVM. No tocante aos demais processos, $32 \%$ correspondem a acórdãos de processos cíveis e 12\% cporrespondem a acórdãos de processos do Bacen.

As entrevistas tiveram por objetivo confirmar o entendimento das fases processuais dentro da CVM, incluindo a tomada de decisão pelos membros do Colegiado.

\subsubsection{O processo de julgamento no Colegiado}

Em entrevista com o advogado Luiz Leonardo Cantidiano, sobre os trâmites processuais, ele menciona que antigamente o Colegiado se envolvia na aprovação da proposta de instauração 
de inquérito. Isso gerava um desconforto pois o Colegiado, responsável pelo julgamento, também participava do processo de acusação. Esse procedimento foi modificado pela própria CVM e atualmente o Colegiado não mais interfere na fase de acusação.

Com relação à percepção e à avaliação do entrevistado sobre as melhorias no processo de julgamento, de maneira geral, Cantidiano diz que em sua opinião há duas questões que são relevantes e que já estão contempladas na legislação. A primeira delas é a possibilidade da realização de Termos de Compromisso. Isso diminui a demanda com relação ao volume de processos. Ao se eliminar uma quantidade de processos por meio da celebração de termos de compromisso, que não é a aplicação de uma penalidade, isso sinaliza para o mercado alguma coisa. Então você diminui o estoque de processos.

Então, além da existência do termo de compromisso, outro ponto importante foi a reforma de 2002 que implementou a mudança de se poder julgar os processos com base em sua relevância. Antes da reforma, os processos eram julgados pela ordem cronológica. "Hoje a CVM pode, pela lei, julgar na frente processos que tenham relevância maior”.

Então, na opinião do entrevistado, essas duas mudanças foram importantes para o aprimoramento do julgamento dos processos na CVM. Ele ainda comentou que vem observando mudanças positivas no funcionamento dos processos do órgão regulador, mencionando treinamentos oferecidos pela SEC e recursos recebidos do Banco Mundial para essas destinações específicas.

Cantidiano ainda complementa:

Outra questão que eu acho, aí não é um defeito da lei, não adianta mudar, o burocrata tem muito receio de ser acusado de omissão. Então tolices, coisas irrelevantes que não trouxeram consequências, são objeto ou de termo de acusação ou de inquérito. E isso acaba acavalando um processo, porque muitos processos você demora para poder instaurar; buscar provas, fundamentar e acusar. E coisas que não têm relevância. A CVM tem um ditado que mais ou menos prevalece como bordão, assim, "um automóvel passou o farol vermelho, não bateu; não atropelou; não trouxe consequência, mas isso é uma irregularidade, tem que ser punido". Então você tem uma quantidade grande de processos que vão para julgamento que não são nada relevantes. Você poderia estar concentrado em coisas especialmente importantes.

A respeito das oportunidades de melhoria sobre os processos de julgamento, Luciana Dias menciona a falta de recursos. Os membros do Colegiado têm diversas atribuições, como fazer representação internacional, preparação de materiais, participar dos julgamentos sancionadores, não sancionadores etc. Além disso, ela reforça a ideia de pessoas com perfis adequados para compor o Colegiado. A diversificação de profissionais enriqueceria as decisões do órgão. 
O professor Eliseu Martins menciona as oportunidades de melhoria nos processos de julgamento na CVM:

(i) Existência de um contador nos julgamentos.

(ii) Muitas questões dos problemas tratados no Colegiado e os que seguem depois para o Conselhinho (CRSFN) focam muito na interpretação jurídica. A análise factual, análise econômica e de substância acaba às vezes ficando de lado.

Ainda, segundo o professor Eliseu Martins, uma experiência internacional que é válida compartilhar é a participação de um expert no julgamento. Se existe um assunto que nenhum dos membros julgadores se sente confortável em julgar, é necessário convocar um expert para participar desse julgamento. E não necessariamente esse profissional teria direito de voto, mas sim o direito e a obrigação de expressar sua opinião. Mas, nesse contexto, deveriam ser pessoas convocadas pelos próprios julgadores, e não pelas partes. Em sua opinião, isso sem dúvida reduziria muito os problemas que temos com julgamentos. "Caso não haja óbices legais para isso, temos que tentar dar um jeito de legalizar (...) de a CVM levar isso para o Congresso".

Em contraposição a essa visão, o advogado Pedro Marcílio menciona que o problema relacionado ao AEG de razoabilidade é a falta de verba definitiva sobre o assunto, especificamente sobre qual o limite das responsabilidades.

Não parta do pressuposto de que o AEG é fruto do desconhecimento dos standards de auditoria, essa é a visão dos auditores. Os que defendem a maior responsabilização acham que há um desconhecimento pelos que defendem a não responsabilização no que se refere às regras gerais de responsabilização profissional.

O problema que existe é a falta de regra definitiva sobre o assunto. Sobre qual é o limite. Porque a gente sabe que, principalmente no Brasil, não é porque contratou de uma determinada forma que não tem responsabilidade. Há uma série de normas e expectativas que sobrepõem a vontade das partes. A grande falha no Brasil e (...) isso é no mundo todo, a falha é que eu não vi em nenhum lugar regular isso de forma definitiva.

E complementa:

Enron muda o paradigma completamente. Muda. Ali ficou claro que a vida não é assim, não é o que eles [auditores] querem. Só que não se regulou muito a responsabilidade desde então. E nem eles próprios [auditores] têm coragem de regular ou de pedir a regulação, porque sabem que o único caminho possível é a redução desse expectation gap contra a posição atual dos auditores. Qualquer avanço, não vai ser pró auditor.

Ele enxerga que há duas soluções, mutuamente exclusivas, para acabar com esse problema, as quais seriam: (i) o regulador intervir e alterar a estrutura de mercado, permitindo a entrada de participantes menores e aumentando a competição ou (ii) a imposição de uma responsabilidade muito maior do que a que existe hoje. Essa segunda solução seria mais relacionada a um movimento mundial, não apenas relacionado ao Brasil. 
Com base nas informações obtidas nas entrevistas, sem dúvida existem questões e pontos que podem ser melhorados com relação aos processos na CVM. Ter profissionais suficientes para executarem as tarefas do dia a dia e direcionar as atividades dos profissionais relacionados aos julgamentos é uma delas. Outra questão relevante é a diversificação na composição do Colegiado que será explicitada no tópico a seguir.

\subsubsection{Composição do Colegiado}

Durante a análise das conclusões dos processos em questão, o cerne da existência do AEG de razoabilidade, para esta pesquisa, está direcionado à opinião dos advogados e juízes presentes nos respectivos julgamentos. Sobre isso, torna-se evidente e iminente, no caso dos julgamentos da CVM, por exemplo, a composição do Colegiado da CVM e sua influência nas decisões analisadas.

A questão que surge refere-se à competência e ao conhecimento da matéria em questão pelos advogados. Não se questiona aqui a competência dos profissionais para os julgamentos, mas sim, nos casos em que se tratar de assuntos específicos, muitas vezes discutidos pelos profissionais envolvidos e órgãos de classe, como é o caso da delimitação das responsabilidades dos auditores independentes.

Uma solução, em minha opinião, para tentar minimizar esse problema acerca dos conhecimentos dos profissionais envolvidos em julgamentos específicos contra auditores independentes seria considerar uma diversificação de profissionais em sua composição, como, por exemplo, com um contador. Esse tema também foi abordado nas entrevistas feitas com os ex-membros do Colegiado da CVM.

Sobre a questão da diversificação da composição do Colegiado da CVM, o advogado Luiz Leonardo Cantidiano destaca:

O Colegiado da CVM deveria ser integrado basicamente por profissionais ligados ao mercado. Gente que jogou o jogo entende como as coisas acontecem. Gente que comprou e vendeu empresa, renegociou passivo, deliberou processo de incorporação de empresa, que atua ou atuou como administradores, gestores de recursos, fundos etc. Não concordo com a composição do Colegiado sendo constituída apenas por acadêmicos ou funcionários públicos.

E ainda complementa:

Eu acho que o Colegiado deve, na minha visão, ter um funcionário público, de preferência da própria CVM, que conheça detalhes da administração pública e que tenha relações com outros órgãos de governo. Eu acho que você tem que ter necessariamente um advogado. Eu acho que 
você deve ter, na minha visão, alguém que seja de mercado e possa ajudar a melhorar a regulamentação do mercado para estimular e facilitar a aplicação das normas no sentido de buscar solidificar e desenvolver o mercado.

O advogado destaca a ida do Prof. Dr. Eliseu Martins ao Colegiado no momento de transição da Lei das S.A.: "Eu entendi que precisávamos ter alguém do mercado que pudesse analisar as questões típicas e específicas para ajudar na regulamentação". E ainda: "Então vou dizer, idealmente, eu acho que deveria compor o Colegiado da CVM alguém com expertise em contabilidade e auditoria".

Sobre a questão da diversificação do Colegiado da CVM, a entrevistada Luciana Dias afirma que

Essa tentativa de você fazer uma interlocução entre profissionais de diversas áreas do mercado existe em vários lugares. No Brasil, ela sempre foi um pouco mais difícil, porque a CVM é um órgão ligado ao Ministério da Fazenda, e o processo de indicação é a última das prioridades. É difícil arrumar alguém bom, que queira ir.

E, ainda, conclui:

Mas o fato é que o Colegiado diversificado tende a ter discussões mais ricas do que o Colegiado não diversificado. Profissionais do direito são importantes, principalmente profissionais que vejam os 2 lados.

Sobre o período no qual o professor Eliseu Martins participou do Colegiado, especificamente 2008-2009, suas funções estavam mais relacionadas à implementação das Leis 11.638/07 e 11.941/09. Segundo o próprio professor, ele não abdicou de nenhuma outra responsabilidade ou compromisso dos profissionais que ocupam esse cargo, o que inclui participação em julgamentos, sendo inclusive relator. Para auxiliá-lo no processo de julgamento, uma de suas primeiras providências foi contratar uma assessora para auxiliá-lo a relatar processos.

O professor Eliseu Martins revelou que antes de sua participação na CVM, em 1985, nunca houve pleito para participação de contadores no Colegiado. Relembra que sua primeira participação, no período de 1985 a 1988, foi por indicação do então presidente da CVM, professor Adroaldo Moura da Silva. Posteriormente houve a indicação de mais três contadores, dentre eles, o Prof. Dr. Nelson Carvalho ${ }^{43}$. Após isso, o professor Eliseu Martins esclareceu que, no período de 1992 a 2008, ou seja por 16 anos, não houve a participação de um contador no Colegiado (houve apenas um e por pouco tempo, nesse período). No entanto, para esse período, sempre houve pleito para a participação de contadores. A justificativa dada pelo

\footnotetext{
${ }^{43}$ Nota desta autora: Outro contador que exerceu a função de Diretor da CVM foi Arthur Escodro.
} 
regulador para a não inclusão ou participação de contadores, de forma constante no Colegiado, segundo o professor Eliseu Martins, era a de que o maior volume de casos julgados não era especificamente relacionado à contabilidade, mas sim a problemas jurídicos e de mercado. A presença dos profissionais da Superintendência de Contabilidade da CVM, segundo o regulador, era suficiente para suas necessidades.

Com a modificação da Lei das S.A.s e a movimentação do país para adoção de padrões contábeis internacionais em 2008, percebeu-se essa necessidade na CVM. Segundo o professor Eliseu Martins, discorrendo sobre seu segundo período de participação no Colegiado, "foi daí que a Presidente Maria Helena Santana mudou de opinião e precisava mesmo, porque ela não queria ficar submetida exclusivamente ao pessoal da casa".

Depois do período de permanência do professor Eliseu Martins, ele insistiu muito com o regulador para que fosse mantido um contador por mais um tempo, durante a implantação das IFRSs. A Presidente Maria Helena concordou com isso e então o Prof. Dr. Alexsandro Broedel foi indicado para a Diretoria. Após a saída do professor Broedel, não houve, novamente, outro contador.

Sobre a composição do Colegiado da CVM, o professor Eliseu Martins também mencionou:

Eu sempre disse que lá precisa haver 2 advogados. Não pode deixar de ter nunca, inclusive não é bom ter 1 só, para não ter uma linha predominante sozinha. Então eu sempre dizia que precisa ter: (i) 2 advogados, eu acho absolutamente necessário, (ii) 1 economista, para ter a visão macro de mercado, (iii) 1 pessoa de mercado, que tenha vivência de mercado, não como advogado, alguém do lado dos investidores, ou do lado mesmo dos administradores das companhias, ou um analista, alguém que tenha essa vivência e (iv) 1 contador. Eu sempre achei que precisava. Eu nunca me convenci dessa história de que o volume de problemas de natureza contábil do Colegiado não é muito significativo, sabe?

E ainda complementou:

Inclusive, há uma coisa que é a seguinte: há assuntos que não são exatamente de contabilidade, mas você tendo um bom profissional de contabilidade, com vivência na área, pode ajudar muito. Eu acho que contribuí em alguns processos lá os quais não tinham nada a ver com contabilidade, mas por causa do tipo de vivência e de experiência na área da gente.

O professor Eliseu Martins afirmou que quando o assunto é relacionado à auditoria, a situação é mais problemática.

Se você vai discutir uma republicação de balanço, uma questão exclusivamente contábil, você pode encontrar, entre os membros do Colegiado, alguma pessoa com melhores condições para discutir um assunto de contabilidade. Quando você entra na parte de auditoria, dificilmente eles terão conhecimento ou terão trabalhado em qualquer área da auditoria. 
Adicionalmente, o professor Eliseu Martins mencionou que, com relação aos assuntos contábeis, os técnicos (integrantes da Superintendência Técnica da CVM) auxiliam bastante, mas questões sobre auditoria são mais problemáticas mesmo. Por tudo isso, a questão nesses dois casos - contabilidade e auditoria - é o perigo do viés das opiniões nas conclusões do Colegiado com base nas opiniões das Superintendências do próprio regulador. Nesse caso, não há um contraponto do Colegiado da CVM.

Luciana Dias ainda menciona que outra preocupação deveria ser o perfil dos profissionais do Colegiado:

Então, eu acho que tem que ser diverso, mas eu acho também que tem que tomar cuidado com essa diversidade e não necessariamente você precisa ter todos os perfis lá. Porque sobretudo está se fazendo política pública. Aquilo não é um órgão privado. Quando você fala em CVM, em política pública, a pessoa tem que ter consciência disso e tem que saber a importância disso.

A escolha de pessoas com perfis não adequados pode tornar as decisões mais burocráticas no regulador.

O entrevistado Pedro Marcílio diz que a existência de um contador no Colegiado da CVM não auxiliaria ou melhoraria o processo de julgamento. De acordo com esse profissional, "o Gap não é de conhecimento técnico, porque o conhecimento das regras de responsabilidade é algo da técnica jurídica e não da técnica contábil’. E complementa:

Responsabilidade profissional é tipicamente norma de Direito, que exige conhecimento jurídico, então o contador não seria o melhor para julgar, pois não tem o conhecimento para julgamento. O contador, em tal processo, funciona melhor como um "expert", que utiliza seu conhecimento para facilitar o julgamento.

O advogado ainda menciona:

A questão é que a auditoria é algo que foi auto-regulada durante muitas décadas, e eles [auditores] não entenderam o mundo em que estão vivendo. Eles têm de entender quais são as regras impostas para eles. Então ninguém fala que há um déficit de conhecimento do advogado quando trata das outras matérias. Ele pode não entender a técnica, mas a técnica tem que ser explicada aos decisores.

A percepção de que um Colegiado diversificado traria melhorias na qualidade das discussões do Colegiado parece ser comum acordo para a maioria dos entrevistados. Mesmo que não seja possível manter um profissional dedicando seu tempo integralmente aos processos, foi considerada uma solução alternativa, com o caso da presença de um expert em matérias mais específicas, como nos casos de julgamentos que envolvem as responsabilidades dos auditores independentes. O fato de um dos entrevistados não concordar ser uma matéria que demandasse um especialista para sua conclusão já denota uma possível causa de problemas de expectativas. 
Ter profissionais a par de questões discutidas sobre um tema específico que está em pauta é saudável para o debate e pode trazer perspectivas e pontos de vista relevantes em um ambiente de julgamento. Isso, sem dúvida, seria um endereçamento do AEG de razoabilidade no ambiente de julgamento no Brasil.

\subsubsection{Limitações da pesquisa e sugestões de futuras pesquisas}

Sobre o desenho da pesquisa, especificamente sobre os processos cíveis, embora tenham sido considerados os tribunais que concentram maiores processos contra as firmas de auditoria, trabalhou-se com uma amostra que se entende ser uma representação significativa da população. Deve-se levar em conta a existência de processos que não foram capturados para esta pesquisa. Adicionalmente foram analisados, tanto no caso dos processos cíveis quanto no dos administrativos, os acórdãos disponíveis nos websites dos reguladores e órgãos pertinentes.

Com relação aos processos administrativos, foram considerados o Bacen e a CVM. No âmbito do Sistema Financeiro Nacional, não foi escopo deste trabalho a análise dos processos existentes no ambiente da Susep. Também não esteve no escopo deste trabalho processos no âmbito do CFC/CRC. Adicionalmente, com relação aos processo do Bacen, foram obtidas apenas as decisões de $2^{\mathrm{a}}$ instância, publicadas pelo CRSFN. Como sugestão de futuras pesquisas, a obtenção dos acórdãos dos julgamentos na $1^{\mathrm{a}}$ instância, no âmbito do Bacen, traria melhores resultados na identificação e possíveis endereçamentos do AEG de razoabilidade para esse regulador.

Sobre a análise da presente pesquisa, ela foi desenhada para levar em consideração os argumentos presentes nos acórdãos dos processos mencionados neste trabalho. A análise desses documentos é apenas a visão sob o prisma de um processo judicial cível ou administrativo.

De acordo com Bauer e Gaskell, (2015, p. 203)

A análise de conteúdo é uma construção social. Como qualquer construção viável, ela leva em consideração alguma realidade, nesse caso, o corpus do texto, e ela deve ser julgada pelo seu resultado. Esse resultado, contudo, não é o único fundamento para se fazer uma avaliação.

Consoante mencionado neste trabalho, os acórdãos dos processos cíveis e administrativos constituíram o objeto deste estudo. Cumpre-me destacar e esclarecer que não foram analisadas as manifestações, escritas e faladas, nem tampouco os documentos, como as provas, para se ter um entendimento de todas as informações que foram discutidas e levadas em consideração no contexto do julgamento. 
No caso dos acórdãos mais concisos, por exemplo, provavelmente ocorreram discussões acerca das responsabilidades do auditor, durante os respectivos julgamentos, que não puderam ser capturadas nesta pesquisa. Para tanto, recomenda-se para pesquisas futuras, no que tange à identificação do AEG, a presença nos julgamentos para que seja possível obter mais detalhes sobre as argumentações dos juízes nesses casos.

Outra consideração importante é o fato de terem sido analisadas, nos acórdãos e documentos anexos ao processo, quando necessário, apenas as discussões relacionadas às responsabilidades do auditor. Cumpre esclarecer e destacar que não foi objetivo deste trabalho relacionar a decisão em cada processo com a existência do AEG de razoabilidade.

Sobre o constructo de Porter (1990), é importante mencionar que a categorização do gap proposta pela autora em gap de razoabilidade, desempenho e padrões deficientes considerou o contexto normativo à época da pesquisa. No entanto, as frequentes as discussões acerca dos papéis e responsabilidades do auditor e amadurecimento dos mercados podem alterar essa classificação.

No que tange a trabalhos exploratórios sobre a existência e ocorrência do AEG, outra sugestão para futuras pesquisas seria a investigação dos mecanismos institucionais e culturais sobre a diferença de expectativas de auditoria, assim como feito por Haniffa e Hudaid (2007) na Arábia Saudita. Obter a percepção sobre esses tipos de mecanismos auxiliaria no endereçamento do gap.

Além disso, para reflexões futuras também caberia a discussão sobre o aperfeiçoamento da legislação que regula o mercado financeiro e de capitais além do delineamento das prórias normas profissionais, com discriminação das funções do auditor forense, por exemplo, especificamente no que tange as responsabilidades dos auditores.

Outra sugestão para pesquisa futura seria a análise do desalinhamento sobre o entendimento das responsabilidade do auditor presente nas peças relacionadas aos processos judiciais. 


\section{CONSIDERAÇÕES FINAIS}

Diante da crescente demanda por credibilidade no Sistema Financeiro Nacional e no mercado, de maneira geral, umas das atividades que constantemente chama atenção com relação a aspectos de governança dentro das empresas é a do auditor independente. Essa atividade, por vezes, ganha determinado destaque em situações negativas, como em casos de episódios de fraudes e outros escândalos financeiros. Normalmente são nesses momentos que a atividade do auditor é questionada. Mais do que isso, tem-se a expectativa de que os auditores desempenhem ou sejam responsáveis por determinadas funções que, em alguns casos, podem não ser atribuídas a eles. Nasce aí uma das formas do que a literatura chama de Audit Expectation Gap (AEG).

Um dos trabalhos mais relevantes sobre a definição de AEG é o de Porter (1990). Segundo a autora deste trabalho, o AEG pode ser dividido em dois componentes: (i) Gap de Desempenho e (ii) Gap de Razoabilidade. O primeiro pode ainda ser dividido em (a) Desempenho Deficiente e (b) Padrões Deficientes.

O Gap de 'razoabilidade' ou de 'expectativas não razoáveis' refere-se à diferença de expectativas, relativamentes às quais os usuários das informações financeiras entendem que os auditores devem executar determinada tarefa, quando de fato eles não têm a obrigação de fazêla.

Este trabalho teve como objetivo identificar a existência do AEG de razoabilidade nas decisões de litígios nos quais as empresas de auditoria figuram como polo passivo. A intenção foi verificar se existem indícios de diferença de expectativas com relação ao trabalho do auditor nos documentos de conclusão dos processos cíveis e administrativos. Esse tipo de evidência pode estar diretamente relacionado com a decisão do juiz, pois foram pautados nos argumentos dos acórdãos em que a decisão foi tomada. Tem-se, nesse caso, uma das formas de materialização do AEG.

O assunto em questão trata de uma visão ainda não explorada no Brasil e pouco explorada internacionalmente. Grande parte das pesquisas teve como foco a identificação do AEG em diversos países, utilizando como base a metodologia proposta por Porter (1990).

A intenção desta pesquisa foi ir além da identificação da existência do AEG em grupos específicos e explorar a sua ocorrência no sistema jurídico brasileiro, principalmente na opinião 
dos juízes nas decisões de processos judiciais. Outro aspecto inovador do trabalho foi a construção de um banco de dados que contempla os processos judiciais que envolvem as maiores firmas de auditoria independente no Brasil, de acordo com as necessidades desta pesquisa. Por meio deste trabalho, portanto, foi possível obter um panorama de como a ocorrência do AEG está presente e pode afetar as partes envolvidas nessas questões, especificamente as empresas de auditoria independente.

Trata-se de um tema importante e relevante não apenas para os auditores independentes, como também para o mercado, reguladores e acadêmicos. A identificação de uma questão ou de um problema e os debates acerca desse tema trazem benefícios não apenas para uma classe específica, mas podem contribuir para o endereçamento de possíveis soluções ou melhorias dos mecanismos de governança corporativa e do mercado de capitais.

A pesquisa consistiu na análise do conteúdo de acórdãos, documentos que contém manifestações dos juízes ralacionadas a processos cíveis e administrativos (CVM e Bacen). Esses documentos foram obtidos nos websites dos respectivos tribunais de justiça e reguladores. Quando necessário, também foram consultados outros documentos anexos aos processos. A análise foi direcionada para os temas que estavam relacionados à responsabilidade dos auditores nos respectivos documentos. Após essa análise, os trechos de interesse para a pesquisa foram categorizados da seguinte forma: (i) Fraude, (ii) Continuidade, (iii) Outros - Não divulgação de informação relevante e (iv) Outros - Procedimentos. Para facilitar a análise dos dados, foi utilizado o software NVivo.

Durante a análise dos acórdãos, tanto cíveis quanto administrativos, foi possível perceber, claramente, a existência do AEG. Sobre os resultados da pesquisa, do total de 34 acórdãos analisados foram identificados 10 casos de AEG de razoabilidade. Isso corresponde a $29 \%$ do total de processos analisados. Nota-se ainda uma presença maior de AEG de razoabilidade na esfera cível e no Bacen, quando se trata de processos administrativos.

Aqui é importante mencionar que durante a análise dos acórdãos, na busca pelo gap de razoabilidade, também foi identificada a existência do gap de desempenho.

Com relação às características dos processos, é importante salientar que a maioria dos processos administrativos tem como natureza o questionamento de procedimentos efetuados pelo auditor, enquanto que os processos cíveis estão mais relacionados com dois grandes temas que são fraude e continuidade operacional das empresas auditadas. 
Como já dito, o gap de desempenho não foi o foco da análise desta pesquisa. Embora o foco também tenha sido a opinião de juízes por meio da análise dos acórdãos, é importante esclarecer que, durante a leitura de outros documentos anexos aos processos, como petições iniciais, liminares, entre outros, é latente a existência do AEG, por parte dos diversos participantes e envolvidos no ambiente e no contexto jurídico. A diferença de expectativas com relação ao trabalho do auditor pode ser observada por parte das empresas e pessoas físicas, que são as autoras dos processos, por advogados envolvidos e também por parte dos juízes.

Especificamente com relação aos processos administrativos, é perceptível que, nas suas decisões de voto, os juízes e conselheiros envolvidos trazem para a discussão o papel e as funções do auditor de forma mais constante. Isso denota mais conhecimento sobre essa matéria, por parte dos envolvidos, mesmo que nesses casos também se perceba a existência do AEG de razoabilidade. Sobre isso, vale ressaltar que os acórdãos foram objeto de análise e que, portanto, não se pode afirmar, por exemplo, a profundidade com que esse assunto foi discutido durante toda a fase processual e no julgamento, no caso dos cíveis.

Os resultados encontrados nesta pesquisa estão em consonância com o resultado apontado pela literatura internacional (Porter, 1990), especificamente no que tange às principais expectativas que envolvem o AEG do auditor independente:

-Auditor como o garantidor da acurácia das demonstrações financeiras das empresas,

-Auditores, informando antecipadamente problemas de continuidade operacional de uma companhia,

-Auditores como responsáveis pela detecção de fraudes,

-Auditores como responsáveis por descobrir e reportar atos ilegais dentro das companhias, e

-Auditores responsáveis por reportar suas preocupações para as entidades regulatórias.

Além da análise dos processos cíveis e administrativos, também foram conduzidas entrevistas com ex-membros do Colegiado da CVM. Como o maior número de acórdãos analisados foi originado desse órgão regulador, além da riqueza de detalhes nos documentos analisados, julgou-se importante obter uma visão sobre a experiência de profissionais envolvidos nos julgamentos. 
As entrevistas basearam-se basicamente no entendimento, para a presente pesquisa, sobre os julgamentos no Colegiado da CVM. Algumas questões importantes apontadas pelos entrevistados sobre as possíveis melhorias nos processos de julgamento são: (i) maior número de pessoas para dar suporte aos trabalhos dos juízes (ii) composição de um Colegiado diversificado e (iii) composição do CRSFN diversificado.

No tocante ao tópico da diversificação da composição do Colegiado da CVM, cumpre destacar que se trata de uma questão importante, não apenas para os julgamentos no âmbito da auditoria, mas para as decisões de maneira geral. No caso das questões relacionadas ao auditor independente, por se tratar de uma discussão específica, a presença de um profissional de contabilidade poderia trazer benefícios às discussões. Uma alternativa no caso de não haver um contador como um membro fixo do Colegiado da CVM seria utilizar a estrutura de experts para julgamentos nos quais se faz necessária a figura de um especialista.

Esta pesquisa traz contribuições importantes não apenas para os profissionais de auditoria independente como também para o tema de regulação do mercado brasileiro. A identificação e o entendimento do problema são fundamentais para endereçar possíveis soluções. Trazer para discussão as principais funções do auditor independente, por meio de processos judiciais, é muito custoso e, em muitos casos, pode não ser a solução mais eficiente. Educar os usuários das demonstrações financeiras sobre os papéis e as responsabilidades da administração é medida que vem sendo apontada na literatura nos últimos anos. É fundamental considerar razoável atenção à educação jurídica, especificamente a profissionais que ocuparão cargos que tenham envolvimento em decisões relacionadas a direito empresarial. O Judiciário, neste caso, deveria estar melhor equipado para o atendimento de matérias relacionadas a contabilidade e finanças.

Além disso, considerar a diversificação na composição do Colegiado da CVM ou mesmo a utilização de especialistas em julgamentos, especificamente no caso dos processos administrativos, poderia trazer muito mais qualidade às discussões judiciais e, consequentemente, reduziria o risco de decisões com base em argumentos equivocados, bem como os custos para as firmas de auditoria e para o Sistema Financeiro Nacional e setor financeiro empresarial em geral. A produção e disponibilização de materiais educativos, divulgados pelo Ibracon, mencionando o papel da auditoria forense, por exemplo, também poderiam auxiliar na redução do AEG de razoabilidade. 
Alterações regulatórias mais enfáticas sobre a obrigatoriedade da auditoria forense, por exemplo, mesmo que fosse para um grupo determinado de empresa, como as empresas de capital aberto, também é uma medida que pode começar a delimitar melhor os papéis e responsabilidades com relação fraude e consequentemente reduzir tanto o AEG de razoabilidade quanto o de desempenho.

Outras medidas, como a modificação do modelo do relatório do auditor também é um assunto bastante debatido pela classe contábil. O modelo do relatório do auditor é uma questão discutida internacionalmente, decorrente da identificação de AEG em diversos países. A eficácia da implementação do novo modelo, no que tange à redução da existência do AEG, poderá ser observada nos próximos anos. Por enquanto, a identificação do problema sob outros pontos de vista pode auxiliar em seu combate de forma mais efetiva. 


\section{REFERÊNCIAS}

ACFE - Association of Certified Fraud Examiners. (2016). Report to the Nations on Occupational Fraud and Abuse. 2016 Global Fraud Study. Disponível em http://www.acfe.com/rttn2016.aspx

Agência Estado. (2002, 16 de agosto). Justiça condena Banco Econômico a indenizar acionistas. Disponível em http://economia.estadao.com.br/noticias/geral,justicacondena-banco-economico-a-indenizar-acionistas,20020816p35900

Albuquerque, K. S., Filho, J. M., \& Bruni, A. L. (2010). Um estudo empírico sobre a produção de legitimidade em auditoria e as expectation gap. In Congresso USP de Controladoria e Contabilidade, 10.

Alleyne, P., \& Howard, M. (2005). An exploratory study of auditors' responsability for fraud detection in Barbados. Managerial Auditing Journal, 20(3), 284-303.

Almeida, J. E., \& Almeida, J. C. (2009, maio/agosto). Auditoria e earnings management: estudo empírico nas empresas abertas auditadas pelas big four e demais firmas de auditoria. Revista de Contabilidade e Finanças, 20(50), 62-74.

Arrington, C. E., Hillison, W. A., \& Williams, P. F. (1983). The Psychology of Expectations Gaps: Why Is There So Much Dispute About Auditor Responsibility? Accounting and Business Research, 13(52).

Assunção, J., \& Carrasco, V. (2008). Avaliação da rotatividade dos auditores independentes. Rio de Janeiros: Pontifícia Universidade Católica do Rio de Janeiro.

Banco Central do Brasil - BACEN. (2015, 18 de dezembro). Manual da Supervisão. 4 Processo de Supervisão do Sistema Financeiro Nacional. Disponível em https://www3.bcb.gov.br/gmn/visualizacao/listarDocumentosManualPublico.do?meth od=visualizarDocumentoCodigoFormatado\&codigoFormatado=1.4.50.10\&idManual= 1

Bardin, L. (2011). Análise de Conteúdo. (L. A. Reto, \& A. Pinheiro, Trans.) São Paulo: Edições 70.

Batista, C. G., Pereira, A. C., Silva, A. F., \& Imoniana, J. O. (2010). Impacto dos pareceres de auditoria na variação do retorno das ações preferenciais das empresas listadas na bovespa. Congresso USP de Controladoria e Contabilidade, 10.

Bauer, M. W., \& Gaskell, G. (2015). Pesquisa qualitativa com texto: imagem e som: um manual prático (13 ed.). Petrópolis, RJ: Editora Vozes.

Bazeley, P., \& Jackson, K. (2013). Qualitative Data Analysis with Nvivo (2nd ed.). Sage Publication Limited.

Bedard, J. C., Sutton, S. G., Arnold, V., \& Phillips, J. R. (2012). Another Piece of the Expectation Gap: What Do Investors Know About Auditor Involvement with Information in the Annual Report? Current Issues in Auditing, 6(3), A17-A30. 
Best, P. J., Buckby, S., \& Tan, C. (2001). Evidence of the audit expectation gap in Singapore. Managerial Auditing Journal, 16(3), 134-144.

Boyle, D., \& Canning, M. (2005). The Impact of Audit Education on Perceptions of Deficient Auditor Performance. The Irish Accounting Review. The Irish Accounting Review, 12(1), 15-37.

BRASIL. (2010, 2 de agosto). TRIBUNAL REGIONAL FEDERAL DA $1^{\text {a }}$ REGIÃO. Ap 2001.34.00.002072-0/DF. DESEMBARGADORA FEDERAL SELENE DE ALMEIDA. Disponível em http://portal.trf1.jus.br/portaltrf1/pagina-inicial.htm

BRASIL. (2011a). Superior Tribunal de Justiça. AgRg no AGRAVO EM RECURSO ESPECIAL $N^{o} 88.568$ - SP. RELATOR: MINISTRO ANTONIO CARLOS FERREIRA. Disponível em http://www.stj.jus.br/sites/STJ

BRASIL. (2011b). Superior Tribunal de Justiça. RECURSO ESPECIAL $N^{o} 1.283 .737$ - DF. Relator: MINISTRO LUIS FELIPE SALOMÃO. Disponível em http://www.stj.jus.br/sites/STJ

BRASIL. (2012a, 11 de dezembro). TRIBUNAL DE JUSTIÇA DO ESTADO DE SÃO PAULO. ACÓRDÃO - Registro: 2012.0000673801. Relator: PAULO EDUARDO RAZUK. Disponível em http://www.tjsp.jus.br/

BRASIL. (2012b). Superior Tribunal de Justiça. AGRAVO EM RECURSO ESPECIAL $N^{o}$ 140.538 - DF. RELATOR: MINISTRO JOÃO OTÁVIO DE NORONHA. Disponível em http://www.stj.jus.br/sites/STJ

BRASIL. (2013, 28 de agosto). TRIBUNAL DE JUSTIÇA DO ESTADO DE SÃO PAULO. ACÓRDÃO - Registro: 2013.0000513234. Relator: Carlos Abrão. Disponível em http://www.tjsp.jus.br/

BRASIL. (2014a, 09 de dezembro). TRIBUNAL DE JUSTICA DO ESTADO DE SÃO PAULO. Acórdão - Registro: 2014.0000825056. Relator: ÊNIO SANTARELLI ZULIANI. Disponível em from http://www.tjsp.jus.br/

BRASIL. (2014b, 15 de abril). TRIBUNAL DE JUSTIÇA DO ESTADO DE SÃO PAULO. ACÓRDÃO - Registro: 2014.0000230665. RELATOR - Claudio Godoy. Disponível em http://www.tjsp.jus.br/

BRASIL. (2014c, 14 de outubro). TRIBUNAL DE JUSTIÇA DO ESTADO DE SÃO PAULO. Processo Digital $n^{o}$ : 1028724-03.2014.8.26.0100. Juiz(a) de Direito: Dr(a). Leila Hassem da Ponte. Disponível em http://www.tjsp.jus.br/

BRASIL. (2015a, 26 de agosto). TRIBUNAL DE JUSTIÇA DO ESTADO DE SÃO PAULO. ACÓRDÃO - Registro: 2015.0000621798. Relator - James Siano. Disponível em http://www.tjsp.jus.br/

BRASIL. (2015b, 24 de julho). Superior Tribunal de Justiça. AGRAVO EM RECURSO ESPECIAL $n^{\circ} 98643$ - SP (2011/0198292-8). RELATOR : MIN. JOÃO OTÁVIO DE NORONHA. Disponível em http://www.stj.jus.br/sites/STJ 
Braunbeck, G. O. (2010). Determinantes da qualidade das auditorias independentes no Brasil. Tese apresentada ao Departamento de Contabilidade e Atuária da Faculdade de Economia, Administração e Contabilidade da Universidade de São Paulo. São Paulo, Brasil.

Braunbeck, G. O., \& Carvalho, L. N. (2008). De emendas e sonetos: o mercado quer rodízio de auditores? Congresso USP de Controladoria e Contabilidade. São Paulo.

Braunbeck, G. O., \& Carvalho, L. N. (2012). Auditoria Independente. In A. B. Lopes, \& S. d. Iudícibus, Teoria Avançada da Contabilidade. São Paulo: Atlas.

Carvalho, L. N. (1989). O parecer dos auditores independentes sobre as demonstrações contábeis no brasil: estudo das limitações ao seu poder de comunicação. Dissertação apresentada ao Departamento de Contabilidade e Atuária da faculdade de Economia e Administração da Universidade de São Paulo. São Paulo, São Paulo, Brasil.

CFD, F. (2009). Defining a forensic audit. The Journal of Digital Forensics, Security and Law: JDFSL, 4(1), 61.

Christensen, J. A., Byington, J. R., \& Blalock, T. J. (2005). Sarbanes-Oxley: Will you need a forensic accountant? Journal of Corporate Accounting \& Finance, 16(3), 69-75.

Collins, J., \& Hussey, R. (2005). Pesquisa em Administração - um guia prático para alunos de graduação e pós-graduação. Porto Alegre: Bookman.

Conselho da Justiça Federal. (2001, Maio). Conselho da Justiça Federal. Manual do Procedimento Ordinário, Manuais de Procedimentos da Justiça Federal(7), 2 a ed.

Conselho Federal de Contabilidade. (1999). Resolução CFC 836 -Aprova a NBC T 11 - IT 03 - Fraude e Erro.

Conselho Federal de Contabilidade. (2009a). Resolução n ${ }^{\circ} 1.203$, de 27 de novembro de 2009. Aprova a NBC TA 200 - "Objetivos Gerais do Auditor Independente e a Condução da Auditoria em Conformidade com Normas de Auditoria", elaborada de acordo com a sua equivalente internacional ISA 200.

Conselho Federal de Contabilidade. (2009b). Resolução ${ }^{\circ}$ 1.207, de 27 de novembro de 2009. Aprova a NBC TA 240 - "Responsabilidade do Auditor em Relação a Fraude, no Contexto da Auditoria de Demonstrações Contábeis”, elaborada de acordo com a sua equivalente internacional ISA 240.

Conselho Federal de Contabilidade. (2009c). Resolução n ${ }^{\circ} 1.226$, de 27 de novembro de 2009. Aprova a NBC TA 570 - "Continuidade Operacional”, elaborada de acordo com a sua equivalente internacional ISA 570.

Conselho Federal de Contabilidade. (2009d). Resolução n ${ }^{\circ}$ 1.235, de 27 de novembro de 2009. Aprova a NBC TA 720 - "Responsabilidade do Auditor em Relação a Outras Informações Incluídas em Documentos que Contenham Demonstrações Contábeis Auditadas", elaborada de acordo com a sua equivalente internacional ISA 720.

Conselho Federal de Contabilidade. (2009e). Resolução n 1.209, de 27 de novembro de 2009. Aprova a NBC TA 260 - Comunicação com os Responsáveis pela Governança. 
CPC. (2011). Comitê de Pronunciamentos Contábeis. CPC OO (R1) - Estrutura Conceitual para Elaboração e Divulgação de Relatório Contábil-Financeiro. Disponíbel em http://www.cpc.org.br/CPC/Documentos-

Emitidos/Pronunciamentos/Pronunciamento? $\mathrm{Id}=80$

Cristo, A. (2013, 28 de agosto). PwC tera de reparar ex-controladores do Banco Noroeste. Disponível em Consultor Jurídico: http://www.conjur.com.br/2013-ago-28/pwcreparar-ex-controladores-banco-noroeste-25-milhoes

Crumbley, L. D., \& Apostolou, N. G. (2005). The expanding role of the forensic accounting. 14(3), 39-43.

Crumbley, L. D., Heitger, L. E., \& Smith, G. S. (2013). Forensic and Investigative Accounting (Sixth ed.). Wolters Kluer.

CVM. (2001, 2 de agosto). COMISSÃO DE VALORES MOBILIÁRIOS. INQUÉRITO ADMINISTRATIVO $N^{\circ}$ 15/99. Relator: Marcelo F. Trindade. Disponível em http://www.cvm.gov.br/sancionadores/sancionador.html

CVM. (2003, 10 de julho). COMISSÃO DE VALORES MOBILIÁRIOS. SESSÃO DE JULGAMENTO DO INQUÉRITO ADMINISTRATIVO CVM No 31/00. Relator: NORMA JONSSEN PARENTE. Disponível em http://www.cvm.gov.br/sancionadores/sancionador.html

CVM. (2004b, 6 de maio). COMISSÃO DE VALORES MOBILIÁRIOS. SESSÃO DE JULGAMENTO DO PROCESSO ADMINISTRATIVO SANCIONADOR CVM N ${ }^{o} T A$ RJ2001/8029. Relator: WLADIMIR CASTELO BRANCO CASTRO. Disponível em http://www.cvm.gov.br/sancionadores/sancionador.html

CVM. (2004a, 15 de abril). COMISSÃO DE VALORES MOBILIÁRIOS. SESSÃO DE JULGAMENTO DO PROCESSO ADMINISTRATIVO SANCIONADOR CVM $N^{o}$ 17/00. Relator: LUIZ ANTONIO DE SAMPAIO CAMPOS. Disponível em http://www.cvm.gov.br/sancionadores/sancionador.html

CVM. (2004c, 05 de agosto). COMISSÃO DE VALORES MOBILIÁRIOS. SESSÃO DE JULGAMENTO DO PROCESSO ADMINISTRATIVO SANCIONADOR CVM N ${ }^{o}$ 05/02. Relator: Eli Loria. Disponível em http://www.cvm.gov.br/sancionadores/sancionador.html

CVM. (2006, 25 de janeiro). COMISSÃO DE VALORES MOBILIÁRIOS. SESSÃO DE JULGAMENTO DO PROCESSO ADMINISTRATIVO SANCIONADOR CVM N ${ }^{o}$ 09/03. Relator: Wladimir Castelo Branco Castro. Disponível em http://www.cvm.gov.br/sancionadores/sancionador.html

CVM. (2009, 13 de outubro). COMISSÃO DE VALORES MOBILIÁRIOS. EXTRATO DA SESSÃO DE JULGAMENTO DO PROCESSO ADMINISTRATIVO SANCIONADOR $C V M N^{o} R J 2008 / 9120$. Relator: Eli Loria. Disponível em http://www.cvm.gov.br/sancionadores/sancionador.html

CVM. (2010a, 1 de dezembro). COMISSÃO DE VALORES MOBILIÁRIOS. EXTRATO DA SESSÃO DE JULGAMENTO DO PROCESSO ADMINISTRATIVO SANCIONADOR 
$C V M N^{o} R J 2009 / 12495$. Relator: Eli Loria. Disponível em http://www.cvm.gov.br/sancionadores/sancionador.html

CVM. (2010b, 24 de agosto). COMISSÃO DE VALORES MOBILIÁRIOS. EXTRATO DA SESSÃO DE JULGAMENTO DO PROCESSO ADMINISTRATIVO SANCIONADOR $C V M N^{\circ} 15 / 90$. Relator: Otavio Yazbek. Disponível em http://www.cvm.gov.br/sancionadores/sancionador.html

CVM. (2011, 7 de junho). COMISSÃO DE VALORES MOBILIÁRIOS. EXTRATO DA SESSÃO DE JULGAMENTO DO PROCESSO ADMINISTRATIVO SANCIONADOR $C V M N^{o} R J 2010 / 16893$. Diretor Relator: Eli Loria. Disponível em http://www.cvm.gov.br/sancionadores/sancionador/2011/20110607_RJ201016893.ht $\mathrm{ml}$

CVM. (2015, 29 de setembro). COMISSÃO DE VALORES MOBILIÁRIOS. EXTRATO DA SESSÃO DE JULGAMENTO DO PROCESSO ADMINISTRATIVO SANCIONADOR $C V M n^{\circ} R J 2013 / 9762$. Relator: Roberto Tadeu Antunes Fernandes. Disponível em http://www.cvm.gov.br/sancionadores/sancionador.html

De Martini, M., Aw, A., \& Kim, E. M. (2000). An examination of the audit expectation gap in Singapore. Asian Review of Accounting. Asian Review Of Accounting, 8(1), 59-82.

Deangelo, L. E. (1981). Auditor Size and Audit Quality. Journal of Accounting and Economics, 3, 183-199.

Deliberação CVM 538. (2008, 05 de março). Comissão de Valores Mobiliários. Dispõe sobre os processos administrativos sancionadores.

Dennis, I. (2010). What Do You Expect? A reconfiguration of the Audit Expectations Gap. International Journal of Auditing, 14, 130-146.

Dixon, R., Woodhead, A. D., \& Sohliman, M. (2006). An investigation of the expectation gap in Egypt. Managerial Auditing Journal, 21(3), 293-302.

Eden, Y. O. (2003, May). Rethinking sarbanes-oxley: Why the Act doesn't serve the interests of the industry or the markets. CMA Management. Disponível em http://www.thefreelibrary.com/Rethinking+sarbanesoxley\%3A+why+the+Act+doesn't+serve+the+interests+of...-a0102747230

Epstein, M. J., \& Geiger, M. A. (1994, January). Investor views of Audit Assurance: Recent Evidence of The Expectation Gap. Journal of Accountancy, pp. 60-66.

EY Brasil. (2013). Relatório de Sustentabilidade 2013 - Juntos construímos um mundo de negócios melhor. Disponível em http://www.ey.com/Publication/vwLUAssets/Relatorio_Sustentabilidade_2013/\$FILE/ Relatorio_Sustentabilidade_EY_2013.pdf

Fadzly, M. N., \& Ahmed, Z. (2004). Audit expectation gap: The case of Malaysia. Managerial Auditing Journal, 19(7), 897-915.

Fenton, J. E., \& Isaacs, P. (2012). Preparing Deposition Questions: The Critical Role of the Forensic Accountant. Journal of Forensic \& Investigative Accounting, 4(2). 
Fogarty, T. J., Heian, J. B., \& Knutson, D. L. (1991). The rationality of doing "nothing": auditors' responses to legal liability in an institutionalized environment. Critical Perspective on Accounting, 2, 201-226.

Gasparini, D. (2005). Direito administrativo. p. 857.

Gil, A. C. (1999). Métodos e Técnicas de Pesquisa Social (5a ed.). São Paulo: Atlas.

Global Public Symposium. (2006, November). Global Capital Markets and the Global Economy: A Vision from CEAs of International and Audit Networks. Disponível em from http://www.cybsoc.org/CEO_Vision.pdf

Gray, D. (2008). Forensic accounting and auditing: compared and contrasted to traditional accounting and auditing. American Journal of Business Education (AJBE), 1(2), 115126.

Haniffa, R., \& Hudaid, M. (2007). Locating audit expectation gap within a cultural context: The case of Saudi Arabia. Journal of International Accounting, Auditing and Taxation, 16(2), 179-206.

Healy, P. M., \& Palepu, K. G. (2001). Information asymmetry, corporate disclosure, and the capital markets: A review of the empirical disclosure literature. Journal of Accounting and Economics, 31, 405-440.

IAASB (2011, May). Enhanching the value of auditor reporting: exploring options for change. Disponível em https://www.ifac.org/publications-resources/enhancing-valueauditor-reporting-exploring-options-change

IAASB. (2015, January). Basis for Conclusions. Reporting on Audited Financial Statements New and Revised Auditor Reporting Standards and Related Conforming Amendments. Disponível em https://www.iaasb.org/system/files/publications/files/Basis\%20for\%20Conclusions\%2 0-\%20Auditor\%20Reporting\%20-\%20final.pdf

IASB. (2010, September). International Accounting Standards Board. Conceptual Framework. Disponível em http://eifrs.ifrs.org/eifrs/bnstandards/en/2016

IBRACON. (1995, junho). Normas e Procedimentos de Auditoria - NPA 09 - Incertezas. Disponível em http://www.ibracon.com.br/ibracon/Portugues/detPublicacao.php?cod=122

IBRACON. (1995, junho). NPA 09 - Incertezas. Disponível em http://www.ibracon.com.br/Ibracon/Portugues/lisPublicacoes.php?codCat=2

IBRACON. (2014, setembro). Transparência Ibracon. É preciso equilíbrio - Ibracon avança no debate para delimitar a responsabilidade civil dos profissionais(15).

Instrução CVM 308. (1999, 14 de maio). Dispõe sobre o registro e o exercício da atividade de auditoria independente no âmbito do mercado de valores mobiliários, define os deveres e as responsabilidades dos administradores das entidades auditadas no relacionamento com os auditores independentes. Disponível em http://www.cvm.gov.br/legislacao/inst/inst308.html 
Iudícibus, S. (2009). Teoria da Contabilidade (9a ed.). São Paulo: Atlas.

Jennings, M., Kneer, D. C., \& Reckers, P. M. (1993, Spring). The significance of audit decision aids and precase jurists' attitudes on perceptions of audit firm culpability and liability. Contemporary Accounting Research, 9(2), 489-507.

Jensen, M., \& Meckling, W. (1976, October). Theory of the firm: managerial behavior, agency costs and ownership structure. Journal of Financial Economics, 3, 305-360.

Kaplan, R. L. (1987). Accountants Liability and Audit Failures: When the Umpire Strikes Out. Journal of Accounting and Public Policy, 6, 1-8.

Kerlinger, F. N. (1980). Metodologia da pesquisa em ciências sociais: um tratamento conceitual. São Paulo: EPU.

KPMG Brasil. (2014). Relatório de Sustentabilidade 2014 . Disponível em http://www.kpmg.com/br/pt/estudos_analises/artigosepublicacoes/paginas/relatoriosustentabilidade-2014.aspx

Lei 11.941, (2009, maio 27). Altera a legislação tributária federal relativa ao parcelamentoordinário de débitos tributários; concede remissão nos casos em que especifica; institui regime tributário de transição. Disponível em http://www.planalto.gov.br/ccivil_03/_ato2007-2010/2009/lei/111941.htm

Lei 13.105. (2015, março 16). Código de Processo Civil. Disponível em http://www.planalto.gov.br/ccivil_03/_ato2015-2018/2015/lei/113105.htm

Lei 5.869. (1973, janeiro 11). Institui o Código de Processo Civil. Disponível em http://www.planalto.gov.br/ccivil_03/leis/L5869.htm

Lei 6.385. (1976, 12 7). Dispõe sobre o mercado de valores mobiliários e cria a Comissão de Valores Mobiliários. Disponível em http://www.planalto.gov.br/ccivil_03/LEIS/L6385.htm

Leung, P., \& Chau, G. (2001). The problematic relationship between audit reporting and audit expectations: Some evidence from Hong Kong. Advances in International Accounting, 14, 181-200.

Lin, Z. J., \& Chen, F. (2004). An empirical study of audit "expectation gap" in the People's Republic of China. International Journal of Auditing, 8(2), 92-115.

Lopes, A. B., \& Martins, E. (2005). Teoria da Contabilidade - uma nova abordagem. São Paulo: Atlas.

Lowe, J. D. (1994, Summer). The expectation gap in the legal system: Perception differences between auditors and judges. Journal of Applied Business Research, 10(3), 39. Disponível em http://search.proquest.com/docview/227558226?accountid=14643

Lowe, J. D., Smith, J. K., \& Frank, K. E. (2001). The expectation gap: perceptual differences between auditors, jurors and students. Managerial Auditing Journal, 16(3), 145-150. Disponível em http://dx.doi.org/10.1108/02686900110385588 
Luccas, R. G. (2015). Desvendando a opinião da auditoria independente: o resultado da auditoria. Dissertação apresentada ao Departamento de Contabilidade e Atuária, da Faculdade de Economia, Administração e Contabilidade da Universidade de São Paulo. São Paulo.

Martinez, A. L. (2010, Jan/Mar). Quando o conselho de administração e a auditoria evitam o gerenciamento de resultados? Evidências empíricas para empresas brasileiras. Revista de Informação Contábil, 4(1), 76-93.

Martins, G. A., \& Theóphilo, C. R. (2007). Metodologia da Investigação Científica para Ciências Socias Aplicadas. São Paulo: Atlas.

Mcenroe, J. E., \& Martens, S. C. (2001). Auditor's and Investor's Perceptions of the "Expectation Gap". Accounting Horizons, 15(4), 345-358.

Menezes, A. L. (2012). Expectation gap em auditoria: impactos no Brasil após a adoção do projeto Clarity. Dissertação apresentada ao Programa de Pós Graduação em Ciências Contábeis, da Fundação Instituto Capixaba de Pesquisa em Contabilidade, Economia e Finanças - Fucape. Vitória, Espírito Santo, Brasil.

Ministério da Fazenda. (2002, 24 de outubro). CRFSN - CONSELHO DE RECURSOS DO SISTEMA FINANCEIRO NACIONAL. Recurso 3989 - Processo CVM 15/99. Disponível em http://fazenda.gov.br/orgaos/colegiados/crsfn/consulta-processualintermediario

Ministério da Fazenda. (2004, 14 de dezembro). CRFSN - CONSELHO DE RECURSOS DO SISTEMA FINANCEIRO NACIONAL. Recurso 5415 - Processo CVM 31/00. Relator: EDMUNDO DE PAULO. Disponível em http://fazenda.gov.br/orgaos/colegiados/crsfn/consulta-processual-intermediario

Ministério da Fazenda. (2005, 13 de dezembro). CRFSN - CONSELHO DE RECURSOS DO SISTEMA FINANCEIRO NACIONAL. Recurso 4941 - Processo BCB 0001046032. Relator: RAUL JORGE DE PINHO CURRO. Disponível em http://fazenda.gov.br/orgaos/colegiados/crsfn/consulta-processual-intermediario

Ministério da Fazenda. (2008a, 26 de março). CRFSN - CONSELHO DE RECURSOS DO SISTEMA FINANCEIRO NACIONAL. Recurso 6310 - Processo CVM IA 2000-17. Relator: RAUL JORGE DE PINHO CURRO. Disponível em http://fazenda.gov.br/orgaos/colegiados/crsfn/consulta-processual-intermediario

Ministério da Fazenda. (2008b, 27 de maio). CRFSN - CONSELHO DE RECURSOS DO SISTEMA FINANCEIRO NACIONAL. Recurso 9793 - Processo CVM 09/03. Relator: MARCELO PIRES VIEIRA. Disponível em http://fazenda.gov.br/orgaos/colegiados/crsfn/consulta-processual-intermediario

Ministério da Fazenda. (2010, 8 de abril). CRFSN - CONSELHO DE RECURSOS DO SISTEMA FINANCEIRO NACIONAL. Recurso 9659 - Processo BCB 0201144611. Relator: JOHAN ALBINO RIBEIRO. Disponível em http://fazenda.gov.br/orgaos/colegiados/crsfn/consulta-processual-intermediario 
Relator: WALDIR QUINTILIANO DA SILVA. Disponível em http://fazenda.gov.br/orgaos/colegiados/crsfn/consulta-processual-intermediario

Ministério da Fazenda. (2014a, 11 de novembro). CRFSN - CONSELHO DE RECURSOS DO SISTEMA FINANCEIRO NACIONAL. Recurso 13317 - Processo CVM RJ2010-16893. Relator: WALDIR QUINTILIANO DA SILVA. Retrieved from http://fazenda.gov.br/orgaos/colegiados/crsfn/consulta-processual-intermediario

Ministério da Fazenda. (2014b, 8 de março). CRFSN - CONSELHO DE RECURSOS DO SISTEMA FINANCEIRO NACIONAL. Recurso 12794 - Processo CVM RJ-20089120. Relator: Nelson Alves de Aguiar Júnio. Disponível em http://fazenda.gov.br/orgaos/colegiados/crsfn/consulta-processual-intermediario

Ministério da Fazenda. (2014c, 26 de agosto). CRFSN - CONSELHO DE RECURSOS DO SISTEMA FINANCEIRO NACIONAL. Recurso 13282 - Processo CVM 15/1990. Relator: WALDIR QUINTILIANO DA SILVA. Disponível em http://fazenda.gov.br/orgaos/colegiados/crsfn/consulta-processual-intermediario

Ministério da Fazenda. (2015a, 26 de maio). CRFSN - CONSELHO DE RECURSOS DO SISTEMA FINANCEIRO NACIONAL. Recurso 13286 - Processo CVM RJ200912495. Relator: ARNALDO PENTEADO LAUDÍSIO. Disponível em http://fazenda.gov.br/orgaos/colegiados/crsfn/consulta-processual-intermediario

Ministério da Fazenda. (2015b, 24 de novembro). CRFSN - CONSELHO DE RECURSOS DO SISTEMA FINANCEIRO NACIONAL. Recurso 13405 - Processo BCB 1001494887. Relator: ANTONIO AUGUSTO DE SÁ FREIRE FILHO. Disponível em http://fazenda.gov.br/orgaos/colegiados/crsfn/consulta-processual-intermediario

Monroe, G. S., \& Woodliff, D. R. (1994). An empirical investigation of the audit expectation gap: Australian evidence. Accounting and Finance, 34(1), 47-74.

Oliveira, A. Q., \& Santos, N. M. (2007, set/dez). Rodízio de firmas de auditoria: a experiência brasileira e as conclusões do mercado. (USP, Ed.) Revista de Contabilidade e Finanças, 18(45), 91-100.

Oliveira, F. L., \& Silva, V. F. (2005, jan/jun). Processos Judiciais como fontes de dados: poder e interpretação. Sociologias, ano7(13), 244-259.

Oliveira, P. A. (2015). A mudança no relatório do auditor independente em resposta as expectativas de mercado: um auxílio na delimitação de sua responsabilidade? Dissertação apresentada à Banca Examinadora da Pontifícia Universidade Católica de São Paulo - Mestrado em Ciências Contábeis.

Pacini, C., Martin , M. J., \& Hamilton, L. (2000). At the interface of law and accounting: an examination of a trend toward a reduction in teh scope of auditor liability to third parties in the common law countries. American Business Law Journal, 37, 171-225.

Palmrose, Z. V. (1987, Spring). Litigation and Independet Auditors: the Role of Business Failures and Management Fraud. Audititng: A Journal of Practice \& Theory, 6(2), 90103. 
Portaria MF n. 68. (2016, fevereiro). Aprova o Regimento Interno do Conselho de Recursos do Sistema Financeiro Nacional - CRSFN. Disponível em http://www.bcb.gov.br/crsfn/RICRSFN_Portaria\%2068_2016.pdf

Porter, B. (1993). An Empirical Study of the Audit Expectation-Performance Gap. Accounting and Business Research, 24(63), 49-63.

Porter, B. A. (1990). An empirical study of the audit expectation-performance gap. Thesis presented in partial fulfilment of requirements for degree of Doctor of Philosophy in Accountancy. Massey University.

Porter, B., Ó hÓgartaigh, C., \& Baskerville, R. (2012b). Audit Expectation-Performance Gap Revisited: Evidence from New Zealand and the United Kingdom Part 2: Changes in Gap in New Zeland 1989-2008 and United Kingdom 1999-2008. International Journal of Auditing, 16, 101-129.

Porter, B., Ó hÓgartaigh, C., \& Baskerville, R. (2012a). Audit Expectation-Performance Gap Revisited: Evidence from New Zealand and the United Kingdom Part 1: The Gap in New Zeland and the United Kingdom in 2008. International Journal of Auditing, 16, 101-129.

Public Company Accounting Oversight Board - PCAOB. (2007, February 22). Group Meting - Panel Discussion. Forensic Audit Procedures. Disponível em https://pcaobus.org/News/Events/Documents/02222007_SAGMeeting/Forensic_Audit _Procedures.pdf

Ramamoorti, S., Morrison III, D. E., Koletar, J. W., \& Pope, K. R. (2013). A.B.C of Behavioral Forensics - Applying psychology to Financial Fraud Prevention and Detection. New Jersey: Wiley.

Reckers, P. M., Jennings, M., Lowe, J. D., \& Kurt, P. (2007). Judges' Attitudes toward the Public Accounting Profession. European Accounting Review, 16(3), 625-645.

Reis, G. M. (2009). O rodízio de auditores independentes e a análise se existe ou não impactos no gerenciamento de resultados das empresas auditadas. Dissertação de Mestrado apresentada ao Programa de Mestrado em Contabilidade da Faculdade de Ciências Contábeis da Universidade Federal da Bahia. Salvador, Bahia, Brasil.

Resolução Bacen 3.198. (2004, 27 de maio). Altera e consolida a regulamentação relativa à prestação de serviços de auditoria independente para as instituições financeiras, demais instituições autorizadas a funcionar pelo Banco Central do Brasil e para as câmaras e prestadores de serviços. Disponível em http://www.bcb.gov.br/pre/normativos/busca/normativo.asp?tipo=res\&ano=2004\&nu mero $=3198$

Resolução CNSP 118. (2004, 22 de dezembro). Dispõe sobre a prestação de serviços de auditoria independente para as sociedades seguradoras, de capitalização e entidades abertas de previdência complementar e sobre a criação do Comitê de Auditoria. Disponível em http://www.susep.gov.br/textos/resol118-04.pdf 
Ricardino, A., \& Carvalho, L. N. (2004, maio/agosto). Breve retrospectiva do desenvolvimento das atividades de auditoria no Brasil. (USP, Ed.) Revista de Contabilidade \& Finanças(35), 22-34.

Rosemberg, A., \& Souza, L. A. (2009). Notas sobre o uso de documentos judiciais como fonte de pesquisa histórica. Patrimônio e Memória, 5(2), 159-173.

Santos, F. P. (2008). A relação entre o parecer de auditoria e a troca de auditores: uma investigação nas instituições financeiras brasileiras. Dissertação de Mestrado apresentada ao Centro de Formação Acadêmica e Pesquisa da Escola Brasileira de Adminstração Pública e de Empresas da Fundação Getúlio Vargas. Rio de Janeiro, Rio de Janeiro, Brasil.

Sidani, Y. M. (2007). The Audit Expectation Gap: Evidence from Lebanon. Managerial Auditing Journal, 22(3), 288-302.

Sikka, P., Puxty, A., Willmott, H., \& Cooper, C. (1998). The Impossibility of Eliminating the Expectation Gap: Some Theory and Evidence. Critical Perspectives on Accounting, 9, 299-330.

Silva, S. P. (2010). Auditoria independente no Brasil: evolução de 1997 a 2008 e fatores que podem influenciar a escolha de um auditor pel empresa auditada. Dissertação apresentada ao Departamento de Contabilidade e Atuária da Faculdade de Economia, Administração e Contabilidade da Universidade de São Paulo. São Paulo, São Paulo, Brasil.

Sunder, S. (2014). Teoria da Contabilidade e do Controle. São Paulo: Atlas.

Vergara, S. C. (2008). Métodos de Pesquisa em Administração (3a ed.). São Paulo: Atlas S.A.

Watts, R. L., \& Zimmerman, J. L. (1981, March). The markets for independence and independent auditors. Working Paper Series $n^{\circ}$. GPB 80-10.

Watts, R. L., \& Zimmerman, J. L. (1983, October). Agency problems, auditing and the theory of the firm: some evidence. Journal of Law \& Economics, 26, 613-634.

World Bank. (2013). Brazil: Report on Observance of Standards and Codes - Accounting and Auditing. Retrieved 05 13, 2015. Disponível em https://openknowledge.worldbank.org/handle/10986/16681 


\section{APÊNDICES}

Apêndice A - NBC PA - DO AUDITOR INDEPENDENTE .......................................... 168

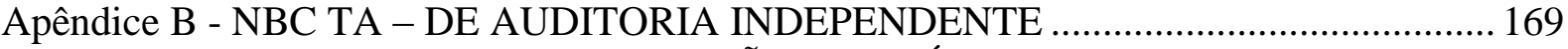

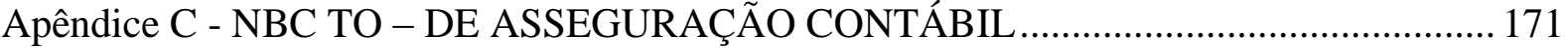

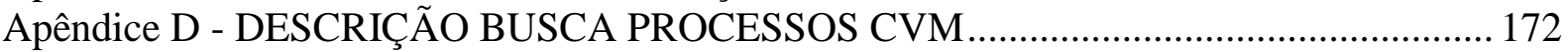

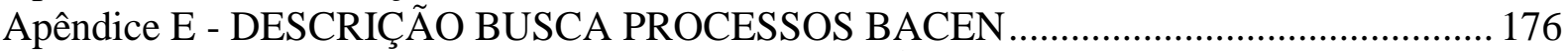

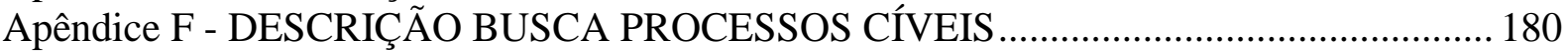

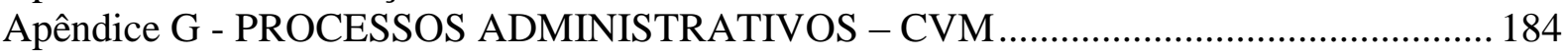

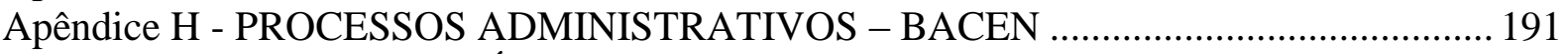

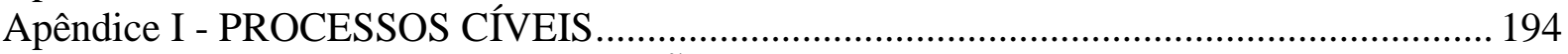

Apêndice J - EMAIL DE TRANSCRIÇÃO DA ENTREVISTA ……................................... 199

Apêndice K - TERMO DE CONSENTIMENTO LIVRE E ESCLARECIDO ..................... 200 


\section{Apêndice A - NBC PA - DO AUDITOR INDEPENDENTE}

\section{Tabela A 1 - Normas do auditor independente}

\begin{tabular}{l|c|l}
\hline Numeração & $\begin{array}{c}\text { CFC } \\
\text { Resolução }\end{array}$ & Nome da norma \\
\hline NBC PA 01 & $1.201 / 09$ & $\begin{array}{l}\text { Controle de Qualidade para Firmas (Pessoas Jurídicas e Físicas) de } \\
\text { Auditores Independentes }\end{array}$ \\
\hline NBC PA 11 & $1.323 / 11$ & Revisão Externa de Qualidade pelos Pares \\
\hline NBC PA 12 & $1.377 / 11$ & Educação Profissional Continuada \\
\hline NBC PA 13 & $1.109 / 07$ & Exame de Qualificação Técnica \\
\hline NBC PA 290 & $1.019 / 05$ & Cadastro Nacional de Auditores Independentes (CNAI) \\
\hline NBC PA 291 & $1.311 / 10$ & Independência - Trabalhos de Auditoria e Revisão \\
\hline
\end{tabular}




\section{Apêndice B - NBC TA - DE AUDITORIA INDEPENDENTE}

\section{Tabela B 1 - NBC TA - Normas técnicas de auditoria independente}

\begin{tabular}{|c|c|c|}
\hline Numeração & $\begin{array}{c}\text { CFC } \\
\text { Resolução }\end{array}$ & Nome da norma \\
\hline $\begin{array}{c}\text { NBC TA } \\
\text { ESTRUTURA } \\
\text { CONCEITUAL }\end{array}$ & $1.202 / 09$ & Estrutura Conceitual para Trabalhos de Asseguração \\
\hline NBC TA 200 & $1.203 / 09$ & $\begin{array}{l}\text { Objetivos Gerais do Auditor Independente e a Condução da Auditoria em } \\
\text { Conformidade com Normas de Auditoria }\end{array}$ \\
\hline NBC TA 210 & $1.204 / 09$ & Concordância com os Termos do Trabalho de Auditoria \\
\hline NBC TA 220 & $1.205 / 09$ & Controle de Qualidade da Auditoria de Demonstrações Contábeis \\
\hline NBC TA 230 & $1.206 / 09$ & Documentação de Auditoria \\
\hline NBC TA 240 & $1.207 / 09$ & $\begin{array}{l}\text { Responsabilidade do Auditor em Relação à Fraude, no Contexto da Auditoria } \\
\text { de Demonstrações Contábeis }\end{array}$ \\
\hline NBC TA 250 & $1.208 / 09$ & $\begin{array}{l}\text { Consideração de Leis e Regulamentos na Auditoria de Demonstrações } \\
\text { Contábeis }\end{array}$ \\
\hline NBC TA 260 & $1.209 / 09$ & Comunicação com os Responsáveis pela Governança \\
\hline NBC TA 265 & $1.210 / 09$ & Comunicação de Deficiências de Controle Interno \\
\hline NBC TA 300 & $1.211 / 09$ & Planejamento da Auditoria de Demonstrações Contábeis \\
\hline NBC TA 315 & $1.212 / 09$ & $\begin{array}{l}\text { Identificação e Avaliação dos Riscos de Distorção Relevante por meio do } \\
\text { Entendimento da Entidade e do seu Ambiente }\end{array}$ \\
\hline NBC TA 320 & $1.213 / 09$ & Materialidade no Planejamento e na Execução da Auditoria \\
\hline NBC TA 330 & $1.214 / 09$ & Resposta do Auditor aos Riscos Avaliados \\
\hline NBC TA 402 & $1.215 / 09$ & $\begin{array}{l}\text { Considerações de Auditoria para a Entidade que Utiliza Organização } \\
\text { Prestadora de Serviços }\end{array}$ \\
\hline NBC TA 450 & $1.216 / 09$ & Avaliação das Distorções Identificadas durante a Auditoria \\
\hline NBC TA 500 & $1.217 / 09$ & Evidência de Auditoria \\
\hline NBC TA 501 & $1.218 / 09$ & Evidência de Auditoria - Considerações Específicas para Itens Selecionados \\
\hline NBC TA 505 & $1.219 / 09$ & Confirmações Externas \\
\hline NBC TA 510 & $1.220 / 09$ & Trabalhos Iniciais - Saldos Iniciais \\
\hline NBC TA 520 & $1.221 / 09$ & Procedimentos Analíticos \\
\hline NBC TA 530 & $1.222 / 09$ & Amostragem em Auditoria \\
\hline NBC TA 540 & $1.223 / 09$ & $\begin{array}{l}\text { Auditoria de Estimativas Contábeis, inclusive do Valor Justo e Divulgações } \\
\text { Relacionadas }\end{array}$ \\
\hline NBC TA 550 & $1.224 / 09$ & Partes Relacionadas \\
\hline NBC TA 560 & $1.225 / 09$ & Eventos Subsequentes \\
\hline NBC TA 570 & $1.226 / 09$ & Continuidade Operacional \\
\hline NBC TA 580 & $1.227 / 09$ & Representações Formais \\
\hline
\end{tabular}




\begin{tabular}{|c|c|c|}
\hline Numeração & $\begin{array}{c}\text { CFC } \\
\text { Resolução }\end{array}$ & Nome da norma \\
\hline NBC TA 600 & $1.228 / 09$ & $\begin{array}{l}\text { Considerações Especiais - Auditorias de Demonstrações Contábeis de } \\
\text { Grupos, incluindo o Trabalho dos Auditores dos Componentes }\end{array}$ \\
\hline NBC TA 610 & $1.229 / 09$ & Utilização do Trabalho de Auditoria Interna \\
\hline NBC TA 620 & $1.230 / 09$ & Utilização do Trabalho de Especialistas \\
\hline NBC TA 700 & $1.231 / 09$ & $\begin{array}{l}\text { Formação da Opinião e Emissão do Relatório do Auditor Independente sobre } \\
\text { as Demonstrações Contábeis }\end{array}$ \\
\hline NBC TA 705 & $1.232 / 09$ & Modificações na Opinião do Auditor Independente \\
\hline NBC TA 706 & $1.233 / 09$ & $\begin{array}{l}\text { Parágrafos de Ênfase e Parágrafos de Outros Assuntos no Relatório do } \\
\text { Auditor Independente }\end{array}$ \\
\hline NBC TA 710 & $1.234 / 09$ & $\begin{array}{l}\text { Informações Comparativas - Valores Correspondentes e Demonstrações } \\
\text { Contábeis Comparativas }\end{array}$ \\
\hline NBC TA 720 & $1.235 / 09$ & $\begin{array}{l}\text { Responsabilidade do Auditor em Relação a Outras Informações Incluídas em } \\
\text { Documentos que Contenham Demonstrações Contábeis Auditadas }\end{array}$ \\
\hline NBC TA 800 & $1.236 / 09$ & $\begin{array}{l}\text { Considerações Especiais - Auditorias de Demonstrações Contábeis } \\
\text { Elaboradas de Acordo com Estruturas Conceituais de Contabilidade para } \\
\text { Propósitos Especiais }\end{array}$ \\
\hline NBC TA 805 & $1.237 / 09$ & $\begin{array}{l}\text { Considerações Especiais - Auditoria de Quadros Isolados das } \\
\text { Demonstrações Contábeis e de Elementos, Contas ou Itens Específicos das } \\
\text { Demonstrações Contábeis }\end{array}$ \\
\hline NBC TA 810 & 1.238109 & $\begin{array}{l}\text { Trabalhos para a Emissão de Relatório sobre Demonstrações Contábeis } \\
\text { Condensadas }\end{array}$ \\
\hline
\end{tabular}




\section{Apêndice C - NBC TO - DE ASSEGURAÇÃO CONTÁBIL}

Tabela C 1 - NBC TO - Normas de asseguração contábil

\begin{tabular}{c|c|l}
\hline Numeração & $\begin{array}{c}\text { CFC } \\
\text { Resolução }\end{array}$ & \multicolumn{1}{c}{ Nome da norma } \\
\hline NBC TO 3000 & $1.160 / 09$ & Trabalho de Asseguração Diferente de Auditoria e Revisão \\
\hline NBC TO 3402 & $1.354 / 11$ & $\begin{array}{l}\text { Relatórios de Asseguração de Controles em Organização Prestadora de } \\
\text { Serviços }\end{array}$ \\
CTO 01 & $1.407 / 12$ & $\begin{array}{l}\text { Emissão de Relatório de Asseguração Relacionado com Sustentabilidade e } \\
\text { Responsabilidade Social }\end{array}$ \\
\hline
\end{tabular}




\section{Apêndice D - DESCRIÇÃO BUSCA PROCESSOS CVM}

1) Website: http://www.cvm.gov.br

2) Link: Atuação Sancionadora

3) Link: Processos Julgados

4) Termos de busca: KPMG, Ernst \& Young, PriceWaterHouseCoopers, Deloitte

As variantes dos termos acima também foram consideradas na busca, como por exemplo, Price WaterHouse Coopers, Ernst Young etc. No caso da PwC e da E\&Y, devido ao fato de apresentarem nomes compostos, a busca foi considerada com por 'todos os termos' e 'expressão exata'. Para as demais empresas foram consideradas buscas por 'expressões exatas' dos nomes.

5) Não foi especificado o período, para que o resultado trouxesse todos os processos existentes.

6) Foram especificados, ainda nos critérios da busca, os 'processos sancionadores julgados', desconsiderando a opção de despacho, pois este não atenderia ao propósito da pesquisa. 
Figura D 1 - Exemplo de busca na página da CVM

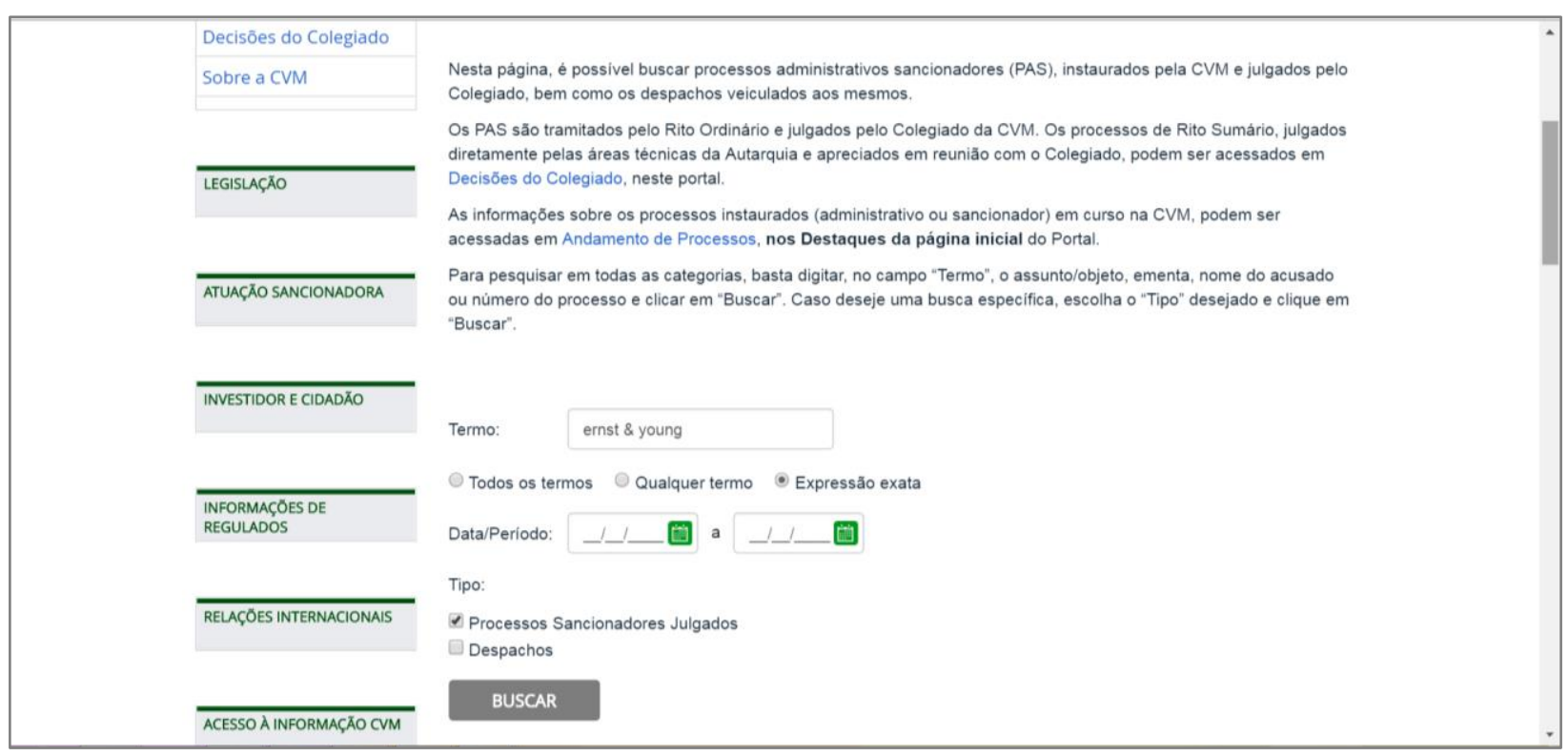

Fonte: http://www.cvm.gov.br/sancionadores/sancionador.html

7) Foram selecionados os processos nos quais as firmas de auditoria constam como 'Acusada' ou como 'Indiciada'.

Seguem as informações sobre a análise dos resultados da busca: 
Tabela D 1 - Resultado de busca por processos na CVM - KPMG

\begin{tabular}{|l|c|c|}
\hline \multicolumn{1}{|c|}{ Processos identificados } & Quantidade & Número dos processos \\
\hline KPMG Acusada & 10 & RJ2013/9762 4 , RJ $2009 / 12495^{44}, 05 / 02$, RJ2001/8029 $9^{44}, 31 / 00,32 / 00^{45}$ \\
\hline KPMG citada no processo & 18 & \\
\hline Total & $\mathbf{2 8}$ & \\
\hline
\end{tabular}

Tabela D 2 - Resultado de busca por processos CVM - Deloitte

\begin{tabular}{|l|c|l|}
\hline \multicolumn{1}{|c|}{ Processos identificados } & Quantidade & Número dos processos \\
\hline Deloitte Acusada & 2 & RJ $2010 / 16893^{44}$ \\
\hline Deloitte citada no processo & 15 & \\
\hline Total & $\mathbf{1 7}$ & \\
\hline
\end{tabular}

Tabela D 3 - Resultado de busca por processos CVM - PwC

\begin{tabular}{|l|c|c|}
\hline \multicolumn{1}{|c|}{ Processos identificados } & Quantidade & Número dos processos \\
\hline PwC Acusada & 3 & $15 / 90,09 / 2003,15 / 99$. \\
\hline PwC citada no processo & 14 & \\
\hline Total & $\mathbf{1 7}$ & \\
\hline
\end{tabular}

Tabela D 4 - Resultado de busca por processos CVM - E\&Y

\begin{tabular}{|l|c|l|}
\hline \multicolumn{1}{|c|}{ Processos identificados } & Quantidade & Número dos processos \\
\hline E\&Y Acusada & 2 & RJ2008/9120, 17/00 \\
\hline E\&Y citada no processo & 13 & \\
\hline Total & $\mathbf{1 5}$ & \\
\hline
\end{tabular}

\footnotetext{
${ }^{44}$ Identificado 2 vezes na busca. Em uma delas, a versão em pdf da conclusão do processo.

${ }^{45}$ Identificado 2 vezes na busca. Em uma delas, a versão em pdf da conclusão do processo. Processo relacionado à independência. Não considerado como objeto de estudo dessa pesquisa.
} 


\section{Apêndice E - DESCRIÇÃO BUSCA PROCESSOS BACEN}

1) Website: http://www.bcb.gov.br

2) Link: Supervisão do SFN

3) Link: Instrumentos Disciplinares Punitivos

4) Link: Processos Administrativos Punitivos

5) Link: Decisões proferidas pelo Conselho de Recursos do Sistema Financeiro Nacional (CRSFN) - $2^{\mathrm{a}}$ instância

4) Termos de busca: KPMG, Ernst \& Young, PriceWaterHouseCoopers, Deloitte. As variantes dos termos acima também foram consideradas na busca, como, por exemplo, Price WaterHouse Coopers, Ernst Young etc. 
Figura E 1 - Exemplo de busca na página Bacen

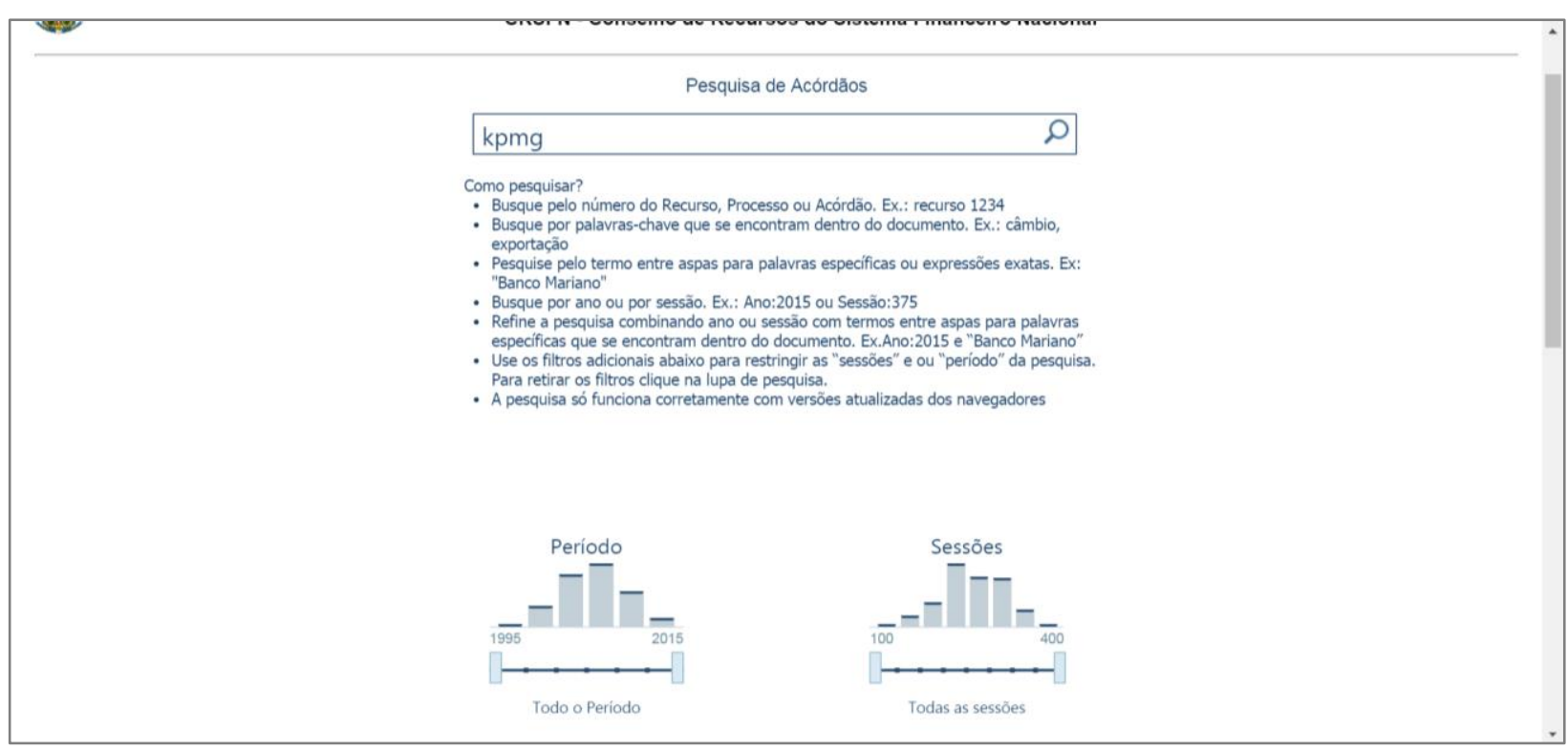

Fonte: http://www.bcb.gov.br/crsfn/ementasacordaos.html

5) Não foi especificado ‘período’ nem ‘sessões', para que o resultado trouxesse todos os processos existentes.

7) Foram selecionados os processos nos quais as firmas de auditoria constam como 'Recorrido' ou como 'Recorrente'.

Seguem as informações sobre a análise dos resultados da busca: 
Tabela E 1 - Resultado de busca por processos Bacen - KPMG

\begin{tabular}{|c|c|c|}
\hline Processos identificados & Quantidade & Número dos processos \\
\hline KPMG Acusada & 4 & $\begin{array}{l}\text { - ACÓRDÃO/CRSFN 4433/03 - (Processo CVM 00/32) } \\
\text { - ACÓRDÃO/CRSFN 5653/04 - Recurso } 5415 \text { (Processo CVM 31/00) } \\
\text { - ACÓRDÃO/CRSFN 11533/15 - Recurso } 13286 \text { (Processo CVM RJ2009-12495) }{ }^{46} \\
\text { - ACÓRDÃO/CRSFN 9580/10 - Recurso } 9659 \text { - Processo BCB 0201144611. }\end{array}$ \\
\hline KPMG citada no processo & 13 & \\
\hline Total & 17 & \\
\hline
\end{tabular}

Tabela E 2 - Resultado de busca por processos Bacen - Deloitte

\begin{tabular}{|l|l|l|}
\hline \multicolumn{1}{|c|}{ Processos identificados } & Quantidade & \multicolumn{1}{c|}{ Número dos processos } \\
\hline Deloitte Acusada & 4 & - ACÓRDÃO/CRSFN 11333/14 - Recurso 13317 - Processo CVM RJ-2010-1689346 \\
& & - ACÓRDÃO/CRSFN 11696/15 - Recurso 13405 - Processo BCB 1001494887 \\
& & $\begin{array}{l}\text { - ACÓRDÃO/CRSFN 3735/02 - Recurso 3921 - Processo CVM RJ2000/373946 } \\
\text { - ACÓRDÃO/CRSFN 7231/05 - Recurso 4941 - Processo BCB 0001046032 }\end{array}$ \\
\hline Deloitte citada no processo & 9 & \\
\hline Total & $\mathbf{1 3}$ & \\
\hline
\end{tabular}

Tabela E 3 - Resultado de busca por processos Bacen - PwC

\begin{tabular}{|c|c|l|}
\hline Processos identificados & Quantidade & \multicolumn{1}{c|}{ Número dos processos } \\
\hline PwC Acusada & 6 & - ACÓRDÃO 8373 - Recurso 9793 (Processo CVM 09/03) ${ }^{46}$ \\
& & - ACÓRDÃO 11331 - Recurso 13282 (Processo CVM 15/1990) ${ }^{46}$ \\
& & - ACÓRD ̃̃O/CRSFN 4608/03 - Recurso 3851 - Processo BCB 9800877835 ${ }^{47}$ \\
\hline
\end{tabular}

\footnotetext{
46 Processo analisado na população de processos da CVM.

47 Os acórdãos obtidos apresentaram conteúdo muito sucinto e não foi possível, apenas por meio desses documentos, fazer a análises pertinentes para os objetivos deste trabalho. Na tentativa de obter mais informações sobre esses casos, foi aberta uma solicitação de melhores informações sobre a conclusão dos respectivos processos, mesmo que fosse o acórdão da decisão da primeira instância, no website do governo federal, por meio do sistema eletrônico do serviço de informação ao cidadão, com respaldo na Lei de Acesso à Informação. A resposta obtida do Departamento de Atendimento Institucional (Deati) do Bacen, no dia 02/09/2016, foi a seguinte:
} 


\begin{tabular}{|l|c|l|}
\hline & & $\begin{array}{l}\text { - ACÓRDÃO/CRSFN 5409/04 - Recurso 3832 - Processo BCB 0001022664 47 } \\
\text { - ACÓRDÃO/CRSFN 3809/02 - Recurso 3989 - Processo CVM 15/9946 } \\
\text { - ACÓRDÃO/CRSFN 3396/01 - Recurso 3099 - Processo origem CVM 15/96 }\end{array}$ \\
\hline PwC citada no processo & 12 & \\
\hline Total & $\mathbf{1 8}$ & \\
\hline
\end{tabular}

Tabela E 4 - Resultado de buscas por processos Bacen - E\&Y

\begin{tabular}{|l|c|l|}
\hline \multicolumn{1}{|c|}{ Processos identificados } & Quantidade & \multicolumn{1}{c|}{ Número dos processos } \\
\hline E\&Y Acusada & 3 & - ACÓRDÃO/CRSFN 11236/14 - Recurso 12794 - Processo CVM RJ-2008-912046 \\
& & $\begin{array}{l}\text { - ACÓRDÃO/CRSFN 8325/08 - Recurso 6310 - Processo CVM IA 2000-1746 } \\
\text { - ACÓRDÃO/CRSFN 11038/12 - Recurso 11981 - Processo BCB 0501284933 }\end{array}$ \\
\hline E\&Y citada no processo & 7 & \\
\hline Total & $\mathbf{1 0}$ & \\
\hline
\end{tabular}

O Banco Central não divulga as decisões de primeira instância de processos administrativos punitivos, em razão dos sigilos bancário e fiscal dos envolvidos. Ressalte-se que o edital de penalidades aplicadas no âmbito dos processos administrativos é informação pública (publicado no Diário Oficial da União). 


\section{Apêndice F - DESCRIÇÃO BUSCA PROCESSOS CÍVEIS}

\section{Exemplo Tribunal de Justiça do Estado de São Paulo}

1) Website do Tribunal de Justiça do estado de São Paulo: http://www.tjsp.jus.br/

2) Link: Consulta de Processos

3) Link: Processos de Segunda Instância ${ }^{48}$

4) Termos de busca:

(i) seção: 'todas as seções'

(ii) pesquisa por: 'nome da parte'.

(iii) nome da parte: KPMG, Ernst \& Young, PriceWaterHouseCoopers, Deloitte

As variantes dos termos acima também foram consideradas na busca, como, por exemplo, Price WaterHouse Coopers, Ernst Young etc.

\footnotetext{
${ }^{48}$ A justificativa para a seleção de processos em segunda instância foi dada na seção 2.5 deste trabalho.
} 
Figura F 1 - Exemplo busca de processo TJSP

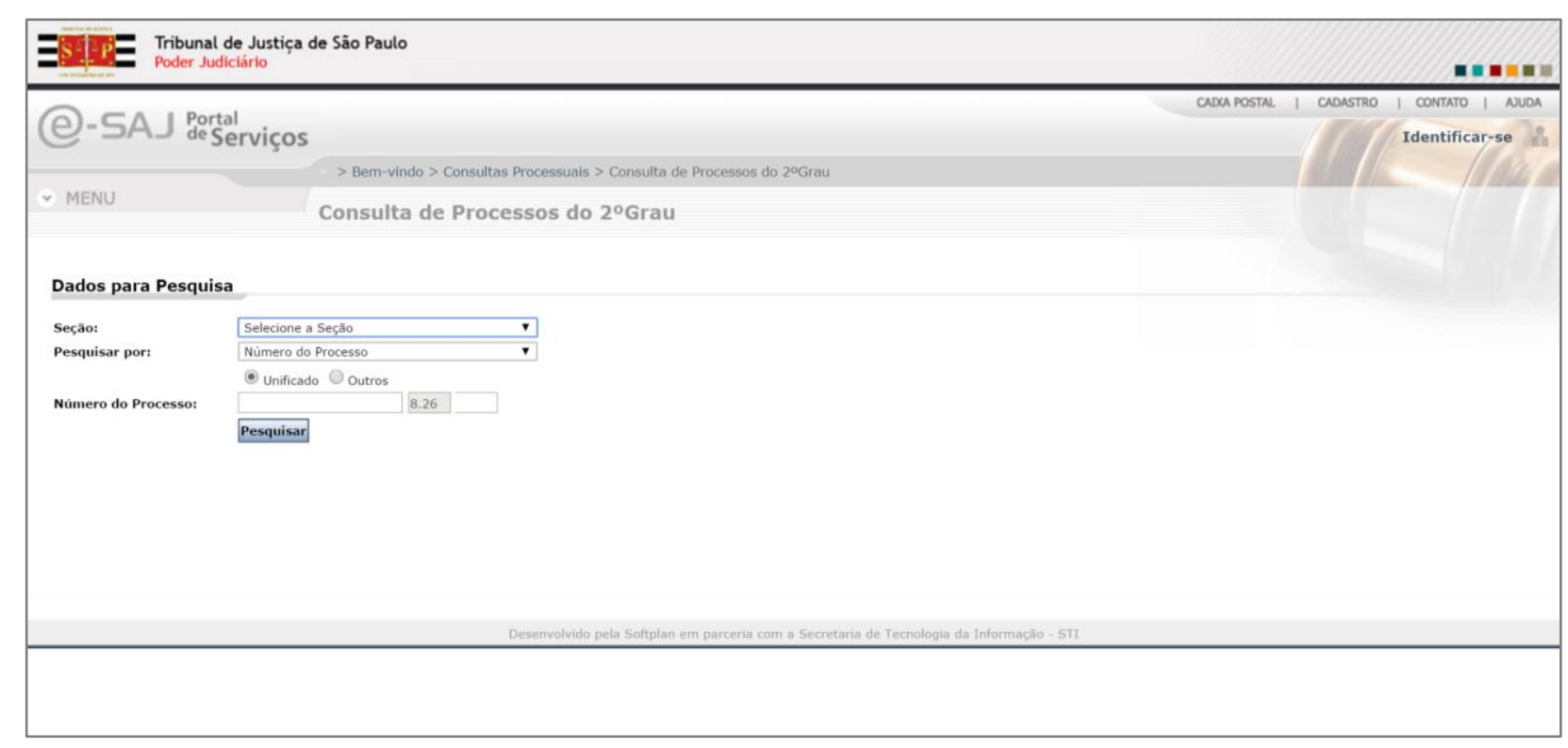

Fonte: http://esaj.tjsp.jus.br/cpo/sg/open.do

\section{Exemplo Tribunal Regional Federal (TRF 1ª Região)}

1) Website do Tribunal Regional Federal ( $1^{\text {a }}$ Região):

2) Link: Consulta de Processual

3) Termos da busca:

(i) seção: TRF $1^{\mathrm{a}}$ Região

(ii) pesquisar por: 'nome da parte'.

(iii) nome da parte: KPMG, Ernst \& Young, PriceWaterHouseCoopers, Deloitte 
As variantes dos termos citadas também foram consideradas na busca, como, por exemplo, Price WaterHouse Coopers, Ernst Young etc.

Figura F 2 - Exemplo de busca TRF

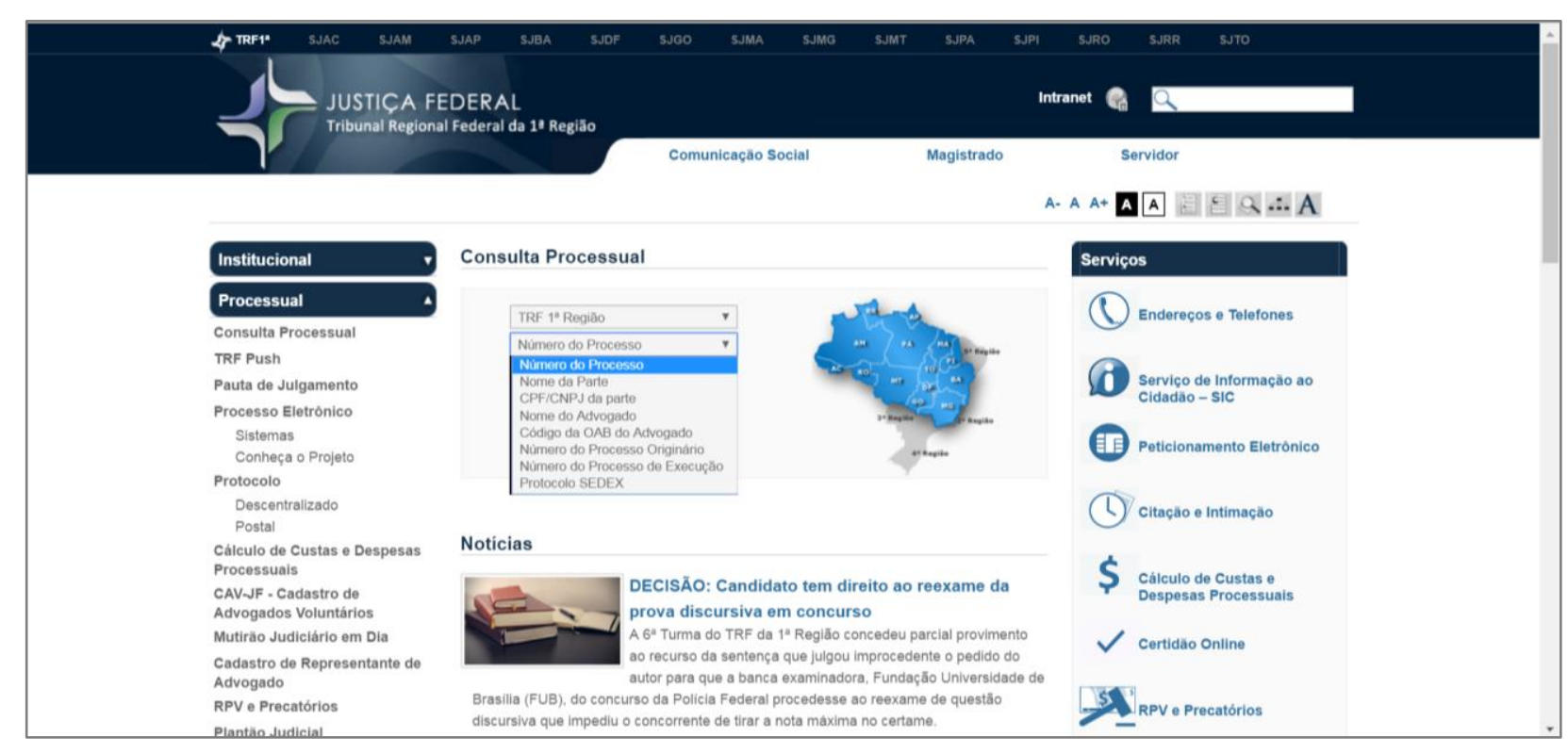

Fonte: http://portal.trf1.jus.br/portaltrf1/pagina-inicial.htm

\section{Exemplo Superior Tribunal de Justiça}

1) Website do Superior Tribunal de Justiça: http://www.stj.jus.br/sites/STJ

2) Link: Processos

3) Link: Consulta Processual 
4) Termos da busca:

(i) Nome da parte: KPMG, Ernst \& Young, PriceWaterHouseCoopers, Deloitte

Foram selecionadas as opções de 'contém' e 'igual' para cada firma de auditoria. As variantes dos termos acima também foram consideradas na busca, como por exemplo, Price WaterHouse Coopers, Ernst Young etc.

\section{Figura F 3 - Exemplo busca Superior Tribunal Justiça}

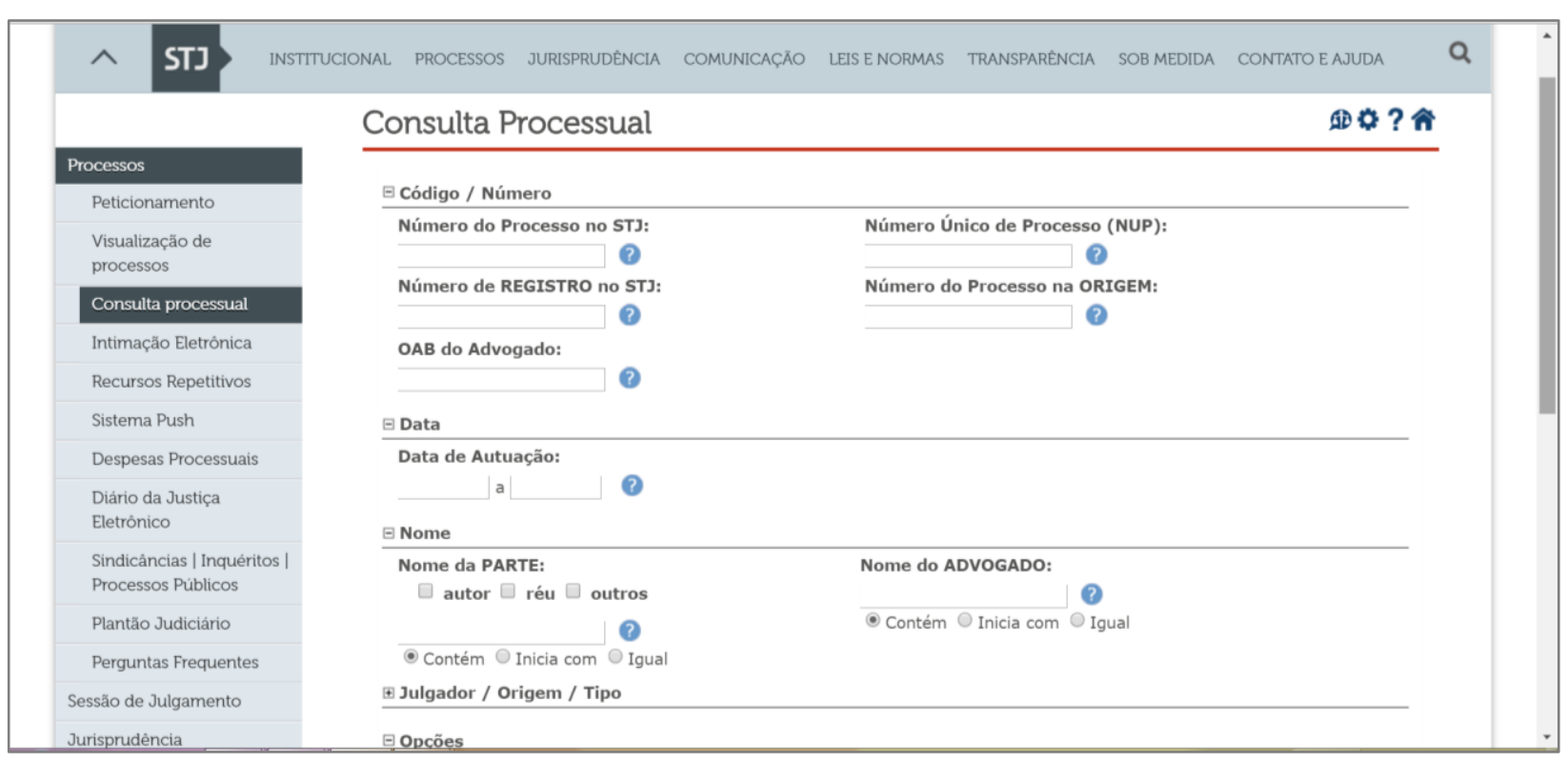

Fonte: https://ww2.stj.jus.br/processo/pesquisa/?aplicacao=processos.ea 


\section{Exemplo Supremo Tribunal Federal}

1) Website do Superior Tribunal de Justiça: http://www.stf.jus.br/portal/principal/principal.asp

2) Link: Acompanhamento Processual

3) Termos da busca:

(i) Partes: KPMG, Ernst \& Young, PriceWaterHouseCoopers, Deloitte

As variantes dos termos acima também foram consideradas na busca, como, por exemplo, Price WaterHouse Coopers, Ernst Young etc.

Figura F 4 - Exemplo busca Supremo Tribunal Federal

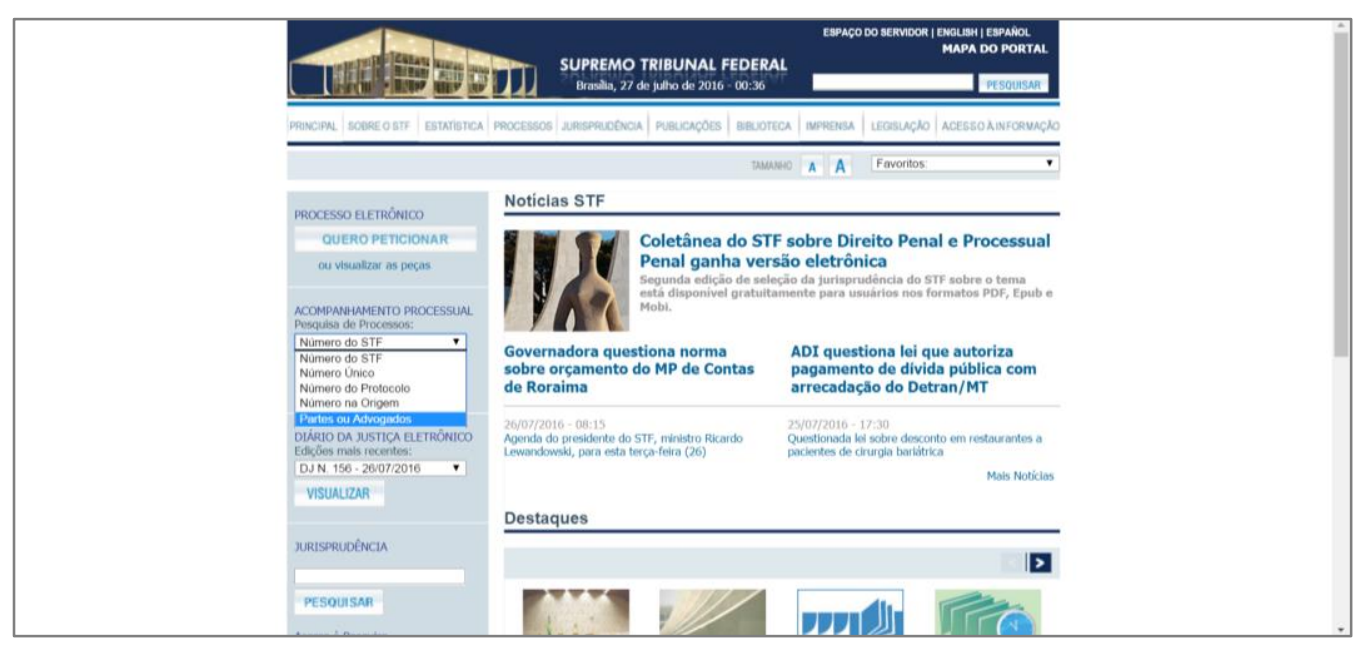

Fonte: http://www.stf.jus.br/portal/principal/principal.asp

Apêndice G - PROCESSOS ADMINISTRATIVOS - CVM 
Tabela G 1 - Informações sobre os processos administrativos CVM

\begin{tabular}{|c|c|c|c|c|c|c|c|}
\hline & $\begin{array}{l}\text { Process } \\
\text { o }\end{array}$ & Data & Tipo & Acusados & Companhia & Ementa & Decisão \\
\hline 1 & $\begin{array}{l}\text { RJ2010/ } \\
16893\end{array}$ & $\begin{array}{c}07 / 06 / 20 \\
11\end{array}$ & $\begin{array}{l}\text { ADMINIST } \\
\text { RATIVO } \\
\text { SANCIONA } \\
\text { DOR }\end{array}$ & $\begin{array}{l}\text { - Deloitte Touche } \\
\text { Tohmatsu Auditores } \\
\text { Independentes } \\
\text { - Maurício Pires de } \\
\text { Andrade Resende }\end{array}$ & $\begin{array}{l}\text { Saraiva S/A } \\
\text { - Livreiros } \\
\text { Editores }\end{array}$ & $\begin{array}{l}\text { Imputação de não emissão de } \\
\text { relatório de revisão especial com } \\
\text { ressalva sobre demonstrações } \\
\text { contábeis da Saraiva S/A Livreiros } \\
\text { Editores referente ao ITR de } \\
\text { 31.03.10, dada a não evidenciação } \\
\text { em nota explicativa específica da } \\
\text { realização de operações com } \\
\text { derivativos. Absolvições. }\end{array}$ & $\begin{array}{l}\text { Vistos, relatados e discutidos os } \\
\text { autos, o Colegiado da Comissão } \\
\text { de Valores Mobiliários, com base } \\
\text { na prova dos autos e na } \\
\text { legislação aplicável, por } \\
\text { unanimidade de votos, decidiu } \\
\text { absolver a Deloitte Touche } \\
\text { Tohmatsu Auditores } \\
\text { Independentes e Maurício Pires } \\
\text { de Andrade Resende da } \\
\text { imputação de descumprimento ao } \\
\text { disposto no art. } 20 \text { e no art. } 25 \text {, I, } \\
\text { "d", da Instrução CVM no } \\
\text { 308/99. }\end{array}$ \\
\hline 2 & $17 / 00$ & $\begin{array}{c}15 / 04 / 20 \\
04\end{array}$ & $\begin{array}{l}\text { ADMINIST } \\
\text { RATIVO } \\
\text { SANCIONA } \\
\text { DOR }\end{array}$ & $\begin{array}{l}\text { - Ernst \& Young } \\
\text { Auditores } \\
\text { Independentes S/C } \\
\text { - Adilson Birolli } \\
\text { Gonzalez } \\
\text { - Affonso Brandão } \\
\text { Hennel } \\
\text { - Carlos Alberto } \\
\text { Americano } \\
\text { - Fernando Henrique } \\
\text { Mendes de Almeida } \\
\text { - Francisco Roberto } \\
\text { Rosas Fernandes } \\
\text { - Nei Antônio de } \\
\text { Lellis } \\
\text { - Samuel Rettmann } \\
\text { - Semp Toshiba } \\
\text { Amazonas S.A. } \\
\text { - Yushi Kokyo }\end{array}$ & $\begin{array}{l}\text { Semp } \\
\text { Toshiba S/A, }\end{array}$ & $\begin{array}{l}\text { Operação entre partes relacionadas - } \\
\text { art. } 245 \text { da Lei no } 6.404 / 76 \text { - conceito } \\
\text { - Deliberação CVM no } 26 / 86 \text { - não } \\
\text { ocorrência da violação do artigo } 117 \text {, } \\
\text { parágrafo primeiro alínea "f", da Lei } \\
\text { n }^{\circ} 6.404 / 76 \text { - absolvição. Não há } \\
\text { violação a estes dispositivos quando } \\
\text { a operação com partes relacionadas é } \\
\text { realizada em condições estritamente } \\
\text { comutativas ou com o pagamento } \\
\text { compensatório adequado. }\end{array}$ & $\begin{array}{l}\text { Vistos, relatados e discutidos os } \\
\text { autos, o Colegiado da Comissão } \\
\text { de Valores Mobiliários, com base } \\
\text { na prova dos autos e na } \\
\text { legislação aplicável, por } \\
\text { unanimidade de votos, decidiu } \\
\text { pela absolvição dos indiciados, } \\
\text { nos termos do exposto no voto do } \\
\text { Diretor-Relator. }\end{array}$ \\
\hline
\end{tabular}




\begin{tabular}{|c|c|c|c|c|c|c|c|}
\hline & $\begin{array}{l}\text { Process } \\
\text { o }\end{array}$ & Data & Tipo & Acusados & Companhia & Ementa & Decisão \\
\hline 3 & $\begin{array}{l}\text { RJ2008/ } \\
9120\end{array}$ & $\begin{array}{c}13 / 10 / 20 \\
09\end{array}$ & $\begin{array}{l}\text { ADMINIST } \\
\text { RATIVO } \\
\text { SANCIONA } \\
\text { DOR }\end{array}$ & $\begin{array}{l}\text { - Ernst \& Young } \\
\text { Auditores } \\
\text { Independentes S/S } \\
\text { - Marcos Antonio } \\
\text { Quintanilha }\end{array}$ & $\begin{array}{l}\text { ALL - } \\
\text { AMÉRICA } \\
\text { LATINA } \\
\text { LOGÍSTICA } \\
\text { S/A }\end{array}$ & $\begin{array}{l}\text { Imputação de ausência de ressalva } \\
\text { nos pareceres de auditoria emitidos } \\
\text { para as demonstrações contábeis } \\
\text { encerradas em 31/12/04, 31/12/05 e } \\
\text { 31/12/06 da ALL - } \\
\text { América Latina Logística S/A, em } \\
\text { infração ao art. 25, I, alínea d, c/c o } \\
\text { art. } 20 \text { da Instrução CVM no } 308 / 99 \text {. } \\
\text { Absolvição. }\end{array}$ & $\begin{array}{l}\text { Vistos, relatados e discutidos os } \\
\text { autos, o Colegiado da Comissão } \\
\text { de Valores Mobiliários, com base } \\
\text { na prova dos autos e na } \\
\text { legislação aplicável, por } \\
\text { unanimidade de votos, decidiu, } \\
\text { preliminarmente, rejeitar a } \\
\text { proposta de Termo de } \\
\text { Compromisso apresentada e } \\
\text { absolver os acusados Ernst \& } \\
\text { Young Auditores } \\
\text { Independentes S/S e Marcos } \\
\text { Antonio Quintanilha das } \\
\text { imputações formuladas. }\end{array}$ \\
\hline 4 & $15 / 99$ & $\begin{array}{c}02 / 08 / 20 \\
01\end{array}$ & $\begin{array}{l}\text { INQUÉRIT } \\
\text { O } \\
\text { ADMINIST } \\
\text { RATIVO }\end{array}$ & $\begin{array}{l}\text { - Unibanco - União } \\
\text { de Bancos } \\
\text { Brasileiros S.A. } \\
\text { - César Augusto } \\
\text { Sizenando Silva } \\
\text { - } \\
\text { PriceWaterhouseCoo } \\
\text { pers Auditores } \\
\text { Independentes } \\
\text { - Ricardo Baldin }\end{array}$ & $\begin{array}{l}\text { Fundos } \\
\text { Administrad } \\
\text { os pelo } \\
\text { Unibanco }\end{array}$ & $\begin{array}{l}\text { I - Limites de concentração de } \\
\text { carteira de fundos, na vigência das } \\
\text { Instruções CVM 177/92, 148/92 e } \\
\text { 215/94. Falta de dispersão } \\
\text { circunstancial. Absolvição. } \\
\text { II - Operações entre fundos sob } \\
\text { administração comum, com seguidos } \\
\text { prejuízos para alguns e lucros para } \\
\text { os outros. Violação do dever de } \\
\text { diligência do art. 10, II, da Instrução } \\
\text { CVM 82/88. Advertência. }\end{array}$ & $\begin{array}{l}\text { (ii) de absolver os indiciados } \\
\text { PriceWaterhouseCoopers } \\
\text { Auditores Independentes e } \\
\text { Ricardo Baldin das imputações } \\
\text { feitas no Relatório da Comissão } \\
\text { de Inquérito, por entender não } \\
\text { ocorrentes as hipóteses previstas } \\
\text { na norma indicada; e }\end{array}$ \\
\hline 5 & $09 / 03$ & $\begin{array}{c}25 / 01 / 20 \\
06\end{array}$ & $\begin{array}{l}\text { ADMINIST } \\
\text { RATIVO } \\
\text { SANCIONA } \\
\text { DOR }\end{array}$ & $\begin{array}{l}\text { - PriceWaterhouse } \\
\text { Coopers - Auditores } \\
\text { Independentes } \\
\text {-Braco S/A } \\
\text {-Carlos Alberto da } \\
\text { Veiga Sicupira } \\
\text {-Carlos Alves de } \\
\text { Brito } \\
\text {-Cláudio Braz Ferro } \\
\text {-Companhia de } \\
\text { Bebidas das } \\
\text { Américas - Ambev } \\
\text {-Companhia }\end{array}$ & $\begin{array}{l}\text { Bebidas } \\
\text { Antarctica } \\
\text { Polar S/A, }\end{array}$ & $\begin{array}{l}\text { Descumprimento do item } 11.3 \text { da } \\
\text { NBC-T-11, do Conselho Federal de } \\
\text { Contabilidade, em infração aos } \\
\text { artigos } 25 \text {, da Instrução CVM no } \\
\text { 216/94, e 20, da Instrução CVM no } \\
\text { 308/99, combinado com o art. } 177, \S \\
3^{\circ} \text {, da Lei no } 6.404 / 76 \text { : pena de } \\
\text { advertência. } \\
\text { Infração ao artigo 178, } 3^{\circ} \text {, } \\
\text { combinado com o art. } 266 \text {, ambos da } \\
\text { Lei no } 6.404 / 76: \text { pena de advertência. } \\
\text { Infração à Deliberação CVM n } \\
\text { 26/86, divulgação inadequada e }\end{array}$ & $\begin{array}{l}\text { Aplicar à PriceWaterhouse } \\
\text { Coopers Auditores } \\
\text { Independentes - Auditores } \\
\text { Independentes a pena de } \\
\text { advertência, por } \\
\text { descumprimento do item 11.3, da } \\
\text { NBC-T-11, emitida pelo } \\
\text { Conselho Federal de } \\
\text { Contabilidade, enquadrando-se, } \\
\text { portanto, no disposto nos artigos } \\
25 \text { da Instrução CVM n } \text { n }^{\circ} 216 / 94 \text { e } \\
20 \text { da Instrução CVM n }{ }^{\circ} 308 / 99 \text {, } \\
\text { combinado com o artigo 177, § }\end{array}$ \\
\hline
\end{tabular}




\begin{tabular}{|c|c|c|c|c|c|c|c|}
\hline & $\begin{array}{l}\text { Process } \\
\text { o }\end{array}$ & Data & Tipo & Acusados & Companhia & Ementa & Decisão \\
\hline & & & & $\begin{array}{l}\text { Brasileira de } \\
\text { Bebidas... }\end{array}$ & & $\begin{array}{l}\text { insuficiente de transações de mútuos } \\
\text { com partes relacionadas: pena de } \\
\text { advertência. }\end{array}$ & $\begin{array}{l}3^{\circ} \text {, da Lei } n^{\circ} 6.404 / 76 \text {, por não ter } \\
\text { ressalvado em seu parecer de } \\
\text { auditoria, relativo ao exercício } \\
\text { social de } 2000 \text {, que os mútuos } \\
\text { foram publicados consolidando } \\
\text { saldos não compensáveis entre si, } \\
\text { e que não houve a devida } \\
\text { transparência nas demonstrações } \\
\text { financeiras quanto às transações } \\
\text { com partes relacionadas, assim } \\
\text { como quanto ao resultado do } \\
\text { exercício e da movimentação da } \\
\text { conta de lucros acumulados. }\end{array}$ \\
\hline 6 & $15 / 90$ & $\begin{array}{c}24 / 08 / 20 \\
10\end{array}$ & $\begin{array}{l}\text { ADMINIST } \\
\text { RATIVO } \\
\text { SANCIONA } \\
\text { DOR }\end{array}$ & $\begin{array}{l}\text {-Price WaterHouse } \\
\text { Coopers Auditores } \\
\text { Independentes } \\
\text {-Gilvandro Fróes } \\
\text { Marques Lobo } \\
\text {-Jacy Flósculo } \\
\text { Goulart } \\
\text {-José Duarte Barbosa } \\
\text { de Almeida } \\
\text {-Nelson Oliveira } \\
\text { Fiúza Lima } \\
\text {-Ricardo de Agostini } \\
\text { Logoeiro } \\
\text {-Yuan Shi Hwa }\end{array}$ & $\begin{array}{l}\text { Barretto de } \\
\text { Araújo } \\
\text { Produtos de } \\
\text { Cacau S.A. }\end{array}$ & $\begin{array}{l}\text { Não convocação de AGO - não } \\
\text { publicação de demonstrações } \\
\text { financeiras - descumprimento do } \\
\text { dever de manter atualizado o registro } \\
\text { de companhia aberta na CVM. } \\
\text { Multas. } \\
\text { Atuação solidária com o controlador } \\
\text { no desvio do objeto social da } \\
\text { Companhia. Inabilitações. } \\
\text { Não emissão de parecer conclusivo } \\
\text { dos auditores quanto à adequação das } \\
\text { Demonstrações Financeiras. } \\
\text { Absolvições. } \\
\text { Não apresentação de ressalva quanto } \\
\text { ao desvio de objeto social. } \\
\text { Absolvições. } \\
\text { Não apresentação de ressalva quanto } \\
\text { à não constitução de provisão para } \\
\text { devedores duvidosos - Auditoria } \\
\text { inepta. Advertências. }\end{array}$ & $\begin{array}{c}\text { 2.5 - Para a PriceWaterHouse } \\
\text { Coopers Auditores } \\
\text { Independentes, na qualidade de } \\
\text { auditor independente da Barreto } \\
\text { de Araújo S/A: } \\
\text { 2.5.1- pela não emissão de } \\
\text { parecer conclusivo quanto à } \\
\text { adequação das DFs referentes ao } \\
\text { exercício social encerrado em } \\
\text { 31.12.1989, ou pela não } \\
\text { indicação das razões pelas quais } \\
\text { declinou de sua emissão - } \\
\text { absolvição; } \\
\text { 2.5.2 - pela não apresentação de } \\
\text { ressalva quanto ao desvio de } \\
\text { objeto social, relativamente aos } \\
\text { exercícios encerrados em } \\
30.6 .1987 \text { e 30.6.1988, em } \\
\text { descumprimento ao art. } 4^{\circ}, \\
\text { incisos I e V, da Instrução CVM } \\
\text { no 38/84 tornando, portanto, a } \\
\text { auditoria inepta, nos termos do } \\
\text { item XVII, letra "f", das Normas } \\
\text { anexas à Instrução CVM no } 4 / 78 \\
\text { - absolvição; }\end{array}$ \\
\hline
\end{tabular}




\begin{tabular}{|c|c|c|c|c|c|c|c|}
\hline & $\begin{array}{l}\text { Process } \\
\text { o }\end{array}$ & Data & Tipo & Acusados & Companhia & Ementa & Decisão \\
\hline & & & & & & & $\begin{array}{c}\text { 2.5.3 - pela não apresentação de } \\
\text { ressalva quanto à não } \\
\text { constituição de provisão para } \\
\text { devedores duvidosos por parte da } \\
\text { Companhia, relativamente aos } \\
\text { exercícios encerrados em } \\
\text { 30.6.1987 e 30.6.1988, em } \\
\text { descumprimento ao art. } 4^{\circ}, \\
\text { incisos I e V, da Instrução CVM } \\
\text { no 38/84 tornando, portanto, a } \\
\text { auditoria inepta, nos termos do } \\
\text { item XVII, letra "f", das Normas } \\
\text { anexas à Instrução CVM n } 4 / 78 \\
\text { - advertência, nos termos do art. } \\
\text { 11, inciso I, da Lei no } 6.385 / 76 .\end{array}$ \\
\hline 7 & $\begin{array}{l}\text { RJ2001/ } \\
8029\end{array}$ & $\begin{array}{c}06 / 05 / 20 \\
04\end{array}$ & $\begin{array}{l}\text { ADMINIST } \\
\text { RATIVO } \\
\text { SANCIONA } \\
\text { DOR }\end{array}$ & $\begin{array}{l}\text {-Vânia Andrade de } \\
\text { Souza } \\
\text {-KPMG Auditores } \\
\text { Independentes }\end{array}$ & $\begin{array}{l}\text { Parcom } \\
\text { Participações } \\
\text { S/A }\end{array}$ & $\begin{array}{l}\text { Emissão de parecer de auditoria sem } \\
\text { ressalva para as demonstrações } \\
\text { financeiras do exercício social } \\
\text { encerrado em 31/12/99 da companhia } \\
\text { aberta Parcom Participações S/A. } \\
\text { Irregularidades configuradas: } \\
\text { Reavaliação de ativo intangível } \\
\text { (passes de atletas profissionais e } \\
\text { amadores), ativação de despesas de } \\
\text { natureza corrente, relativas a gastos } \\
\text { com formação de atletas; e } \\
\text { insuficiência de informações em } \\
\text { notas explicativas relativas a } \\
\text { contratos de mútuo, sem } \\
\text { remuneração, com partes } \\
\text { relacionadas, e ao custo atribuído a } \\
\text { "direito de uso de marca". - Infração } \\
\text { ao art. } 20 \text { da Instrução CVM nº } \\
\text { 308/99. }\end{array}$ & $\begin{array}{l}\text { Vistos, relatados e discutidos os } \\
\text { autos, o Colegiado da Comissão } \\
\text { de Valores Mobiliários, com base } \\
\text { na prova dos autos e na } \\
\text { legislação aplicável, por } \\
\text { unanimidade de votos decidiu } \\
\text { aplicar aos indiciados a pena de } \\
\text { advertência, por infração ao } \\
\text { artigo } 20 \text { da Instrução CVM no } \\
\text { 308/99. }\end{array}$ \\
\hline
\end{tabular}




\begin{tabular}{|c|c|c|c|c|c|c|c|}
\hline & $\begin{array}{l}\text { Process } \\
\text { o }\end{array}$ & Data & Tipo & Acusados & Companhia & Ementa & Decisão \\
\hline 8 & $05 / 02$ & $\begin{array}{c}05 / 08 / 20 \\
04\end{array}$ & $\begin{array}{l}\text { ADMINIST } \\
\text { RATIVO } \\
\text { SANCIONA } \\
\text { DOR }\end{array}$ & $\begin{array}{l}\text {-KPMG Auditores } \\
\text { Independentes } \\
\text {-Aldo Carneiro } \\
\text { Junior } \\
\text {-Banco JP Morgan } \\
\text { S/A (nova } \\
\text { denominação do } \\
\text { Banco Chase } \\
\text { Manhattan S/A) } \\
\text {-César Ribeiro do } \\
\text { Val } \\
\text { - NorChem Holdins } \\
\text { e Negocios S/A } \\
\text { (nova denominação } \\
\text { do Banco NorChem } \\
\text { S/A). }\end{array}$ & $\begin{array}{l}\text {-Ribeirão } \\
\text { Preto Water } \\
\text { Park S/A } \\
\text {-Banco } \\
\text { NorChem } \\
\text { S/A }\end{array}$ & 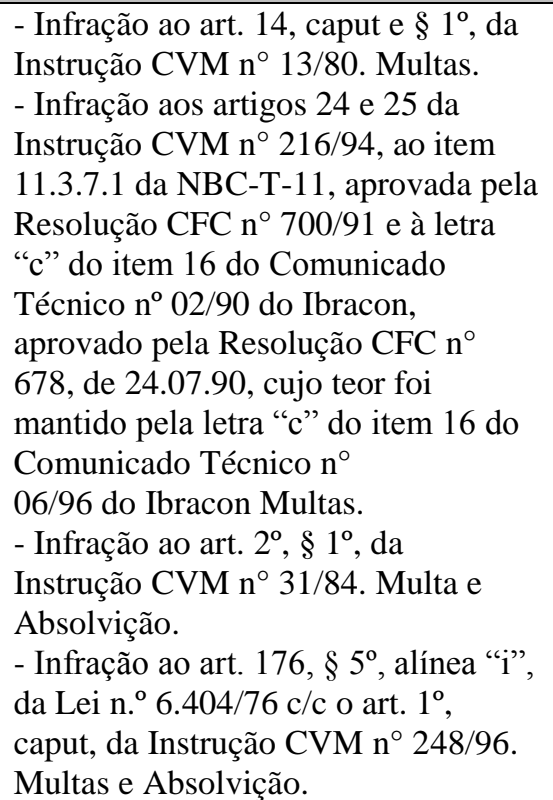 & $\begin{array}{l}\text { b) por unanimidade de votos, à } \\
\text { KPMG Auditores Independentes, } \\
\text { multa pecuniária no valor de R\$ } \\
50.000,00 \text {, e, por maioria de } \\
\text { votos, ao Sr. Fernando Octávio } \\
\text { Sepúlveda Munita, multa no } \\
\text { valor de R } \$ 5.000,00 \text {, por } \\
\text { infração aos artigos } 24 \text { e } 25 \text { da } \\
\text { Instrução CVM n }{ }^{\circ} 216 \text {, de } \\
29.06 .94 \text {, ao item } 11.3 .7 .1 \text { da } \\
\text { NBC-T-11, aprovada pela } \\
\text { Resolução CFC n }{ }^{\circ} 700 / 91 \text { e à } \\
\text { letra "c" do item } 16 \text { do } \\
\text { Comunicado Técnico no } 02 / 90 \text { do } \\
\text { Ibracon, aprovado pela } \\
\text { Resolução CFC n }{ }^{\circ} 678, \text { de } \\
24.07 .90, \text { cujo teor foi mantido } \\
\text { pela letra "c" do item } 16 \text { do } \\
\text { Comunicado Técnico n } 06 / 96 \text { do } \\
\text { Ibracon; }\end{array}$ \\
\hline 9 & $\begin{array}{l}\text { RJ2009/ } \\
12495\end{array}$ & $\begin{array}{c}01 / 12 / 20 \\
10\end{array}$ & $\begin{array}{l}\text { ADMINIST } \\
\text { RATIVO } \\
\text { SANCIONA } \\
\text { DOR }\end{array}$ & $\begin{array}{l}\text {-KPMG Auditores } \\
\text { Independentes } \\
\text { - José Luiz Ribeiro } \\
\text { de Carvalho } \\
\text { - Charles Krieck }\end{array}$ & $\begin{array}{l}\text { Perdigão } \\
\text { S/A, atual } \\
\text { BRF-Brasil } \\
\text { Foods S/A }\end{array}$ & $\begin{array}{l}\text { Não inclusão de ressalva no relatório } \\
\text { de revisão especial sobre } \\
\text { informações trimestrais. Multas. }\end{array}$ & $\begin{array}{l}\text { 1. aplicar à KPMG Auditores } \\
\text { Independentes a penalidade de } \\
\text { multa pecuniária no valor de } \mathrm{R} \$ \\
500.000,00 \text { (quinhentos mil } \\
\text { reais); e } \\
\text { 2. aplicar a José Luiz Ribeiro de } \\
\text { Carvalho e a Charles Krieck a } \\
\text { penalidade de multa pecuniária, } \\
\text { individual, no valor de } \mathrm{R} \$ \\
100.000,00 \text { (cem mil reais). }\end{array}$ \\
\hline $\begin{array}{l}\mathbf{1} \\
\mathbf{0}\end{array}$ & $31 / 00$ & $\begin{array}{c}10 / 7 / 200 \\
3\end{array}$ & $\begin{array}{l}\text { INQUÉRIT } \\
\text { O } \\
\text { ADMINIST } \\
\text { RATIVO }\end{array}$ & $\begin{array}{l}\text { - KPMG Auditores } \\
\text { Independentes } \\
\text { - Antônio Carlos } \\
\text { Caio Simeira Jacob } \\
\text {... }\end{array}$ & $\begin{array}{l}\text { Lojas } \\
\text { Arapuã S/A }\end{array}$ & $\begin{array}{l}\text { Transferência de dívidas e } \\
\text { respectivos recursos para empresas } \\
\text { ligadas, pertencentes ao acionista } \\
\text { controlador, sem a anuência dos } \\
\text { credores, permanecendo a Arapuã } \\
\text { responsável pelo seu pagamento. Não } \\
\text { evidenciação em nota explicativa e } \\
\text { não constituição de provisão mesmo }\end{array}$ & $\begin{array}{c}\text { Multar a KPMG Auditores } \\
\text { Independentes em R } \$ \\
500.000,00 \text { (quinhentos mil } \\
\text { reais), por infração ao artigo } 24 \\
\text { da Instrução CVM n }{ }^{\circ} 216 / 94 \text { por } \\
\text { não seguirem o determinado pelo } \\
\text { Pronunciamento do pela } \\
\text { Deliberação CVM no } 26 / 86 \text { em } \\
\end{array}$ \\
\hline
\end{tabular}




\begin{tabular}{|c|c|c|c|c|c|c|c|}
\hline & $\begin{array}{l}\text { Process } \\
\text { o }\end{array}$ & Data & Tipo & Acusados & Companhia & Ementa & Decisão \\
\hline & & & & & & $\begin{array}{l}\text { quando as dívidas começaram a } \\
\text { voltar. }\end{array}$ & $\begin{array}{c}\text { relação à auditoria das } \\
\text { demonstrações financeiras de } \\
\text { Lojas Arapuã de } 1995 \text { a } 1997 \text { e } \\
\text { por infração ao artigo } 25 \text { da } \\
\text { Instrução CVM n } 216 / 94 \text { por } \\
\text { não observarem as NBCT-11. }\end{array}$ \\
\hline $\begin{array}{l}1 \\
1\end{array}$ & $\begin{array}{l}\text { RJ2013/ } \\
9762\end{array}$ & $\begin{array}{c}25 / 9 / 201 \\
5\end{array}$ & $\begin{array}{l}\text { ADMINIST } \\
\text { RATIVO } \\
\text { SANCIONA } \\
\text { DOR }\end{array}$ & $\begin{array}{l}\text { - KPMG Auditores } \\
\text { Independentes } \\
\text { - Cláudio Rogélio } \\
\text { Sertório }\end{array}$ & FIDC Union & $\begin{array}{l}\text { Emissão de parecer de auditoria } \\
\text { sobre as demonstrações financeiras } \\
\text { do Union National Fundo de } \\
\text { Investimento em Direitos Creditórios } \\
\text { Financeiros e Mercantis, sem } \\
\text { qualquer ressalva, deixando de } \\
\text { observar o disposto nas normas } \\
\text { profissionais de auditoria } \\
\text { independente. }\end{array}$ & $\begin{array}{l}\text { Condenação de KPMG Auditores } \\
\text { Independentes, à penalidade de } \\
\text { multa no valor de R } \$ \\
1.000 .000,00 \text { (hum milhão de } \\
\text { reais), correspondente ao dobro } \\
\text { da multa máxima }\end{array}$ \\
\hline
\end{tabular}




\section{Apêndice H - PROCESSOS ADMINISTRATIVOS - BACEN}

Tabela H 1 - Informações sobre os processos administrativos Bacen

\begin{tabular}{|c|c|c|c|c|c|c|c|}
\hline & Processo & Data & Tipo & Acusados & $\begin{array}{c}\text { Companhi } \\
\mathbf{a}\end{array}$ & Ementa & Decisão \\
\hline 1 & $\begin{array}{l}\text { Processo } \\
\text { BCB } \\
0001046032\end{array}$ & $\begin{array}{c}13 / 12 / 200 \\
5\end{array}$ & $\begin{array}{l}\text { Recurso } \\
4941 \text { - } \\
\text { RECURSO } \\
\text { VOLUNT } \\
\text { ÁRIO }\end{array}$ & $\begin{array}{l}\text { RECORRENTE: } \\
\text { DELOITTE TOUCHE } \\
\text { TOHMATSU } \\
\text { AUDITORES } \\
\text { INDEPENDENTES } \\
\text { RECORRIDO: BANCO } \\
\text { CENTRAL DO BRASIL }\end{array}$ & $\begin{array}{l}\text { Banco Excel } \\
\text { Econômico } \\
\text { S.A. }\end{array}$ & $\begin{array}{l}\text { Auditoria independente - } \\
\text { Situação de iliquidez de } \\
\text { créditos constantes de } \\
\text { demonstrações financeiras } \\
\text { - Emissão de parecer sem } \\
\text { ressalvas - Irregularidade } \\
\text { caracterizada - Apelo a } \\
\text { que se nega provimento. }\end{array}$ & $\begin{array}{l}\text { Decidem os membros do } \\
\text { Conselho de Recursos do Sistema } \\
\text { Financeiro Nacional, por maioria, } \\
\text { e nos termos do voto do } \\
\text { Conselheiro-Relator, negar } \\
\text { provimento ao recurso interposto, } \\
\text { mantida a decisão do órgão de } \\
\text { primeiro grau no sentido de } \\
\text { aplicar a DELOITTE TOUCHE } \\
\text { TOHMATSU AUDITORES } \\
\text { INDEPENDENTES pena de } \\
\text { multa pecuniária no valor de R\$ } \\
\text { 125.000,00 (cento e vinte e cinco } \\
\text { mil reais). }\end{array}$ \\
\hline
\end{tabular}




\begin{tabular}{|c|c|c|c|c|c|c|c|}
\hline & Processo & Data & Tipo & Acusados & $\begin{array}{c}\text { Companhi } \\
\mathbf{a}\end{array}$ & Ementa & Decisão \\
\hline 2 & $\begin{array}{l}\text { Processo } \\
\text { BCB } \\
0501284933\end{array}$ & $\begin{array}{c}05 / 12 / 201 \\
2\end{array}$ & $\begin{array}{l}\text { Recurso } \\
11981 \text { - } \\
\text { RECURSO } \\
\text { (S) } \\
\text { VOLUNT } \\
\text { ÁRIO(S) }\end{array}$ & $\begin{array}{l}\text { RECORRENTE(S): - } \\
\text { ERNST \& YOUNG } \\
\text { AUDITORES } \\
\text { INDEPENDENTES S.S. } \\
\text { - ADILSON BIROLLI } \\
\text { GONZALEZ } \\
\text { RECORRIDO: BANCO } \\
\text { CENTRAL DO BRASIL }\end{array}$ & $\begin{array}{l}\text { Banco } \\
\text { Santos S.A. }\end{array}$ & $\begin{array}{l}\text { O Banco Central do Brasil } \\
\text { instaurou, 15.12.2005, o } \\
\text { presente processo } \\
\text { administrativo contra } \\
\text { Ernst \& Young Auditores } \\
\text { Independentes S.S. e seu } \\
\text { responsável técnico } \\
\text { Adilson Birolli Gonzalez, } \\
\text { pela conduta consistente } \\
\text { na emissão de parecer de } \\
\text { auditoria, sem ressalvas, } \\
\text { relativo às demonstrações } \\
\text { financeiras do Banco } \\
\text { Santos S.A., data-base } \\
\text { 30.6.2003, a despeito do } \\
\text { incremento artificial e } \\
\text { relevante nos resultados } \\
\text { daquela instituição } \\
\text { financeira. }\end{array}$ & $\begin{array}{l}\text { Decidem os membros do } \\
\text { Conselho de Recursos do Sistema } \\
\text { Financeiro Nacional - a) após } \\
\text { rejeitar a questão de preliminar } \\
\text { arguida: a.1) prescrição } \\
\text { intercorrente - b) dar provimento } \\
\text { parcial aos recursos interpostos } \\
\text { por b.1) ERNST \& YOUNG } \\
\text { AUDITORES } \\
\text { INDEPENDENTES S.S. e b.2) } \\
\text { ADILSON BIROLLI } \\
\text { GONZALEZ, convolando em } \\
\text { advertência a decisão do órgão de } \\
\text { primeiro grau no sentido de se } \\
\text { lhes aplicar pena de multa } \\
\text { pecuniária no valor de R\$ } \\
\text { 500.000,00 (quinhentos mil reais) } \\
\text { e pena de proibição temporária, } \\
\text { pelo prazo de 10 (dez) anos, } \\
\text { para praticar atividade de } \\
\text { auditoria em instituições } \\
\text { autorizadas a funcionar pelo } \\
\text { Banco Central do Brasil, } \\
\text { respectivamente. }\end{array}$ \\
\hline
\end{tabular}




\begin{tabular}{|c|c|c|c|c|c|c|c|}
\hline & Processo & Data & Tipo & Acusados & $\begin{array}{c}\text { Companhi } \\
\text { a }\end{array}$ & Ementa & Decisão \\
\hline 3 & $\begin{array}{l}\text { Processo } \\
\text { BCB } \\
0201144611\end{array}$ & $\begin{array}{c}08 / 04 / 201 \\
0\end{array}$ & $\begin{array}{l}\text { Recurso } \\
9659 \text { - I - } \\
\text { RECURSO } \\
\text { S } \\
\text { VOLUNT } \\
\text { ÁRIOS }\end{array}$ & $\begin{array}{l}\text { RECORRENTES: - } \\
\text { KPMG AUDITORES } \\
\text { INDEPENDENTES (EX- } \\
\text { KPMG PEAT } \\
\text { MARWICK) } \\
\text { - WALTER IÓRIO } \\
\text { RECORRIDO: BANCO } \\
\text { CENTRAL DO BRASIL }\end{array}$ & $\begin{array}{l}\text { Banco } \\
\text { Bandeirantes }\end{array}$ & $\begin{array}{l}\text { Trata-se de Recursos } \\
\text { Voluntários e de Ofício } \\
\text { envolvendo a KPMG } \\
\text { Peat Marwick, atual } \\
\text { KPMG Auditores } \\
\text { Independentes, e } \\
\text { responsável técnico, Sr. } \\
\text { Walter Iório, em relação } \\
\text { aos trabalhos de auditoria } \\
\text { independente, realizados } \\
\text { no } \\
\text { antigo Banco } \\
\text { Bandeirantes. }\end{array}$ & $\begin{array}{l}\text { a) aceitar, por maioria, a questão } \\
\text { de preliminar arguida, declarando- } \\
\text { se haver sido caracterizada, na } \\
\text { espécie, prescrição intercorrente e } \\
\text { arquivando-se de conseguinte o } \\
\text { processo no tocante aos recursos } \\
\text { voluntários interpostos por KPMG } \\
\text { AUDITORES } \\
\text { INDEPENDENTES (EX-KPMG } \\
\text { PEAT MARWICK) e WALTER } \\
\text { IÓRIO, e } \\
\text { b) improver, por unanimidade, o } \\
\text { recurso de ofício formulado, } \\
\text { confirmando-se o arquivamento } \\
\text { do processo em relação aos } \\
\text { recorridos, KPMG AUDITORES } \\
\text { INDEPENDENTES (EX-KPMG } \\
\text { PEAT MARWICK) e WALTER } \\
\text { IÓRIO. }\end{array}$ \\
\hline 4 & $\begin{array}{l}\text { Processo } \\
\text { BCB } \\
9800877835\end{array}$ & $\begin{array}{c}10 / 12 / 200 \\
3\end{array}$ & $\begin{array}{l}\text { Recurso } \\
3851- \\
\text { RECURSO } \\
\text { VOLUNT } \\
\text { ÁRIO }\end{array}$ & $\begin{array}{l}\text { RECORRENTE: } \\
\text { PRICEWATERHOUSEC } \\
\text { OOPERS AUDITORES } \\
\text { INDEPENDENTES } \\
\text { RECORRIDO: BANCO } \\
\text { CENTRAL DO BRASIL }\end{array}$ & $\begin{array}{l}\text { Banco } \\
\text { Noroeste } \\
\text { S/A }\end{array}$ & $\begin{array}{l}\text { Auditoria independente - } \\
\text { Não apuração de } \\
\text { discrepâncias } \\
\text { significativas entre os } \\
\text { saldos registrados na conta } \\
\text { D.E.M.E. (Depósitos no } \\
\text { Exterior em Moeda } \\
\text { Estrangeira) da matriz da } \\
\text { instituição financeira } \\
\text { auditada e os efetivamente } \\
\text { existentes no passivo de } \\
\text { agência no exterior } \\
\text { coligada - Irregularidade } \\
\text { caracterizada - Embaraço à } \\
\text { fiscalização não } \\
\text { configurado - Razões de } \\
\text { defesa acolhidas em parte - } \\
\text { Apelo a que se dá } \\
\text { provimento parcial. }\end{array}$ & $\begin{array}{l}\text { Vistos, relatados e discutidos os } \\
\text { presentes autos, decidem os } \\
\text { membros do Conselho de } \\
\text { Recursos do Sistema Financeiro } \\
\text { Nacional dar provimento parcial } \\
\text { ao recurso interposto, mantida a } \\
\text { decisão do órgão de primeiro grau } \\
\text { no sentido de aplicar a } \\
\text { PRICEWATERHOUSECOOPER } \\
\text { S AUDITORES } \\
\text { INDEPENDENTES pena de } \\
\text { multa pecuniária, por ter restado } \\
\text { caracterizada uma das duas } \\
\text { irregularidades apontadas na peça } \\
\text { inicial, reduzindo-se o valor }(\mathrm{R} \$ \\
100.000,00 \text { mais R\$ } 100.000,00 \text { - } \\
\text { cem mil reais, totalizando-se } \mathrm{R} \$ \\
200.000,00 \text { - duzentos mil reais) }\end{array}$ \\
\hline
\end{tabular}




\begin{tabular}{l|l|l|l|l|l|l|l}
\hline Processo & Data & Tipo & Acusados & $\begin{array}{c}\text { Companhi } \\
\text { a }\end{array}$ & Ementa & Decisão \\
\hline & & & & arbitrado na origem para R\$ & $50.000,00$ (cinquenta mil reais). \\
& & & & & & \\
& & & & & & & \\
& & & & & &
\end{tabular}

Apêndice I - PROCESSOS CÍVEIS 
Tabela I 1 - Informações sobre os processos cíveis

\begin{tabular}{|c|c|c|c|c|c|c|c|}
\hline & Processo & Partes & Tipo ação & $\begin{array}{c}\text { Vara/ } \\
\text { Tribunal }\end{array}$ & Status & Companhia & Assunto/ Objeto \\
\hline 1 & $\begin{array}{c}2017526- \\
58.2014 .8 .26 \\
0000\end{array}$ & $\begin{array}{l}\text { Agravante: } \\
\text { Engepack Embalagens } \\
\text { S A } \\
\text { Agravado: Deloitte } \\
\text { Touche Tohmatsu } \\
\text { Auditores } \\
\text { Independentes }\end{array}$ & $\begin{array}{c}\text { AGRAVO DE } \\
\text { INSTRUMENT } \\
\text { O }\end{array}$ & $\begin{array}{c}\text { TJSP - } 1^{\mathrm{a}} \\
\text { Câmara de } \\
\text { Direito } \\
\text { Privado }\end{array}$ & $\begin{array}{c}\text { Arquivado } \\
\text { administrativa } \\
\text { mente }\end{array}$ & Engepack & $\begin{array}{l}\text { A demanda é voltada à condenação de todos os } \\
\text { réus ao pagamento de indenização por danos } \\
\text { materiais (item 154, 'a', da inicial) e morais (item } \\
\text { 154, 'b', da inicial) em razão de alegada gestão } \\
\text { fraudulenta da sociedade empresária autora, com } \\
\text { saques indevidos de valores por cheques } \\
\text { descontados na boca do caixa e justificados com } \\
\text { notas fiscais frias, tudo o que teria sido omitido } \\
\text { de relatórios de auditoria. }\end{array}$ \\
\hline 2 & $\begin{array}{c}\text { Apl. } \\
\text { 9161946- } \\
\text { 23.2003.8.26. } \\
0000\end{array}$ & $\begin{array}{l}\text { Apelante: Leo } \\
\text { Wallace Cochrane } \\
\text { Apelado: } \\
\text { Pricewaterhousecoope } \\
\text { rs Auditores } \\
\text { Independentes S/C }\end{array}$ & Apelação Cível & \begin{tabular}{|c|} 
TJSP - $14^{\circ}-$ \\
$14^{\mathrm{a}}$ Câmara \\
de Direito \\
Privado
\end{tabular} & $\begin{array}{l}\text { Retornou dos } \\
\text { Sup. } \\
\text { Tribunais }\end{array}$ & $\begin{array}{c}\text { Banco } \\
\text { Noroeste }\end{array}$ & $\begin{array}{l}\text { O tema submetido ao enfrentamento concerne às } \\
\text { operações fraudentas praticadas interna } \\
\text { corporis, junto ao Banco Noroeste, cuja } \\
\text { auditoria, pelos contratos trazidos, competia à } \\
\text { empresa Price, sem detectar, diagnosticar, ou se } \\
\text { manifestar de maneira mais enfática sobre } \\
\text { graves desvios acontecidos, sendo assim, os } \\
\text { autores buscam compensação monetária pela } \\
\text { imperícia apresentada pela auditoria externa. }\end{array}$ \\
\hline 3 & $\begin{array}{c}0123784- \\
98.2006 .8 .26 \\
0100\end{array}$ & $\begin{array}{l}\text { Apte/Apdo: } \\
\text { Alexandre Matone } \\
\text { Apdo/Apte: Ernst \& } \\
\text { Young Terco } \\
\text { Auditores } \\
\text { Independentes S/s }\end{array}$ & $\begin{array}{c}\text { Apelação / } \\
\text { Responsabilidad } \\
\text { e Civil }\end{array}$ & $\begin{array}{c}\text { TJSP - } 2^{\mathrm{a}} \\
\text { Vara Cível }\end{array}$ & Encerrado & Banco Santos & $\begin{array}{l}\text { Trata-se de ação de indenização por danos } \\
\text { materiais, em que o autor pretende o } \\
\text { ressarcimento da quantia que aduz ter perdido } \\
\text { em investimentos financeiros realizados junto ao } \\
\text { malfadado Banco Santos. }\end{array}$ \\
\hline 4 & $\begin{array}{c}1028724- \\
03.2014 .8 .26 \\
0100\end{array}$ & $\begin{array}{l}\text { Apelante: } \\
\text { SOCIEDADE } \\
\text { HEBRAICO } \\
\text { BRASILEIRA } \\
\text { RENASCENÇA } \\
\text { Apelado: ERNST \& } \\
\text { YOUNG TERCO } \\
\text { AUDITORES } \\
\text { INDEPENDENTES } \\
\text { S/S }\end{array}$ & Perdas e Danos & $\begin{array}{l}25^{\mathrm{a}} \text { Vara } \\
\text { Cível - } \\
\text { Foro } \\
\text { Central } \\
\text { Cível }\end{array}$ & - & $\begin{array}{c}\text { Sociedade } \\
\text { Hebraico } \\
\text { Brasileira } \\
\text { Renascença }\end{array}$ & $\begin{array}{l}\text { Afirma que o vício no serviço prestado pela } \\
\text { requerida direcionou a autora a realizar } \\
\text { investimentos estruturais, o que acabou se } \\
\text { mostrando um aumento de endividamento que } \\
\text { atualmente a coloca em risco econômico } \\
\text { financeiro. }\end{array}$ \\
\hline
\end{tabular}




\begin{tabular}{|c|c|c|c|c|c|c|c|}
\hline & Processo & Partes & Tipo ação & $\begin{array}{c}\text { Vara/ } \\
\text { Tribunal }\end{array}$ & Status & Companhia & Assunto/ Objeto \\
\hline 5 & \begin{tabular}{|c|} 
0002074- \\
13.2001.4.01. \\
3400 \\
(velha -: \\
2001.34.00.00 \\
2072-0)
\end{tabular} & $\begin{array}{l}\text { Apelante: BANCO } \\
\text { ECONÔMICO S/A - } \\
\text { EM LIQUIDAÇÃO } \\
\text { EXTRAJUDICIAL } \\
\text { MINISTÉRIO } \\
\text { PÚBLICO FEDERAL } \\
\text { Apelado: OS } \\
\text { MESMOS } \\
\text { ERNST E YOUNG } \\
\text { AUDITORES } \\
\text { INDEPENDENTES } \\
\text { S/C E Y }\end{array}$ & $\begin{array}{l}\text { AÇÃO CÍVIL } \\
\text { PÚBLICA }\end{array}$ & $\begin{array}{l}\text { TRF } 1-7^{\mathrm{a}} \\
\text { VARA } \\
\text { FEDERAL }\end{array}$ & $\begin{array}{l}\text { NO(A) } \\
\text { COORD. } \\
\text { REGISTRO } \\
\text { INFO. } \\
\text { PROCESSUA } \\
\text { IS }\end{array}$ & $\begin{array}{c}\text { Banco } \\
\text { Econômico }\end{array}$ & $\begin{array}{l}\text { Questão relativa à responsabilidade civil dos } \\
\text { auditores independentes, dentre outros motivos, } \\
\text { pelos seguintes aspectos circunstanciais } \\
\text { peculiares, a saber: a) a empresa de auditoria ora } \\
\text { recorrida não ressalvou o fato de o Banco } \\
\text { Econômico ter omitido nas notas explicativas } \\
\text { evento subsequente a 30/6/95 com efeito } \\
\text { relevante sobre sua situação financeira e } \\
\text { resultados futuros; b) não fez constar parágrafo } \\
\text { de ênfase referente aos problemas de liquidez da } \\
\text { instituição; c) não fez qualquer ressalva à } \\
\text { delicada situação financeira do banco; d) não } \\
\text { haveria razão plausível para que a dita empresa } \\
\text { de auditoria independente, que figurou como } \\
\text { auditoria externa do Banco Econômico, deixasse } \\
\text { de fazer a necessária ressalva à situação } \\
\text { financeira extremamente dificultosa em que o } \\
\text { banco se encontrava. }\end{array}$ \\
\hline 6 & $\begin{array}{l}2103824- \\
53.2014 .8 .26 \\
0000\end{array}$ & $\begin{array}{l}\text { Agravante: KPMG } \\
\text { AUDITORES } \\
\text { INDEPENDENTES } \\
\text { Agravado: } \\
\text { Ministério Público do } \\
\text { Estado de São Paulo }\end{array}$ & $\begin{array}{l}\text { Agravo de } \\
\text { Instrumento }\end{array}$ & $\begin{array}{l}\text { Comarca de } \\
\text { São Paulo / } \\
\text { Foro } \\
\text { Central } \\
\text { Cível / 1 }{ }^{\text {a }} \\
\text { Vara de } \\
\text { Falências e } \\
\text { Recuperaçõ } \\
\text { es Judiciais }\end{array}$ & Julgado & Banco BVA & $\begin{array}{l}\text { Pretende a KPMG AUDITORES } \\
\text { INDEPENDENTES efeito ativo a um agravo de } \\
\text { instrumento tirado contra decisão que deferiu } \\
\text { (liminar) arresto de seus ativos financeiros. O } \\
\text { despacho agravado considerou presentes indícios } \\
\text { para se admitir, provisoriamente, a participação } \\
\text { fraudulenta (ou com culpa) da empresa de } \\
\text { auditoria externa, por não ter denunciado a } \\
\text { posição patrimonial do Banco BVA, que atuava } \\
\text { no setor conhecido como "middle Market" e que } \\
\text { segundo levantamento do Banco Central, } \\
\text { prejudicou terceiros no montante de R\$ } \\
\text { 1.598.304.768,46. }\end{array}$ \\
\hline
\end{tabular}




\begin{tabular}{|c|c|c|c|c|c|c|c|}
\hline & Processo & Partes & Tipo ação & $\begin{array}{c}\text { Vara/ } \\
\text { Tribunal }\end{array}$ & Status & Companhia & Assunto/ Objeto \\
\hline 7 & $\begin{array}{l}2212188- \\
22.2014 .8 .26 \\
0000\end{array}$ & $\begin{array}{l}\text { Agravante: KPMG } \\
\text { AUDITORES } \\
\text { INDEPENDENTES } \\
\text { Agravado: BASF } \\
\text { S.A. }\end{array}$ & $\begin{array}{l}\text { Agravo de } \\
\text { Instrumento }\end{array}$ & $\begin{array}{l}\text { Comarca de } \\
\text { São Paulo / } \\
\text { Foro } \\
\text { Central } \\
\text { Cível / 25a } \\
\text { Vara Cível }\end{array}$ & Julgado & Basf & $\begin{array}{l}\text { A agravante KPMG Auditores Independentes foi } \\
\text { contratada pela agravada Basf S.A. a fim de que } \\
\text { fossem prestados serviços de auditoria. O } \\
\text { relatório de auditoria produzido pela agravante } \\
\text { amparou a aquisição de estabelecimento } \\
\text { empresarial pela agravada, que, no entanto, } \\
\text { alegou ter sofrido prejuízos dessa avença. } \\
\text { Imputou à agravante a responsabilidade por este } \\
\text { prejuízo, visto que se tomou conhecimento de } \\
\text { inconsistências nos relatórios de auditoria } \\
\text { apresentados. Sobre o serviço de auditora, a } \\
\text { agravada Basf S.A., primeiramente, ajuizou } \\
\text { medida cautelar preparatória com o fim de que } \\
\text { fossem exibidos documentos dessa prestação de } \\
\text { serviço. }\end{array}$ \\
\hline 8 & $\begin{array}{l}\text { AREsp no }^{\circ} \\
140538 / \\
\text { DF(2012/004 } \\
0106-7)\end{array}$ & $\begin{array}{l}\text { AGRAVANTE: } \\
\text { REYNALDO } \\
\text { CATALANO E } \\
\text { OUTRO } \\
\text { AGRAVADO: } \\
\text { KPMG AUDITORES } \\
\text { INDEPENDENTES } \\
\text { AGRAVADO: } \\
\text { BANCO NACIONAL } \\
\text { S/A - EM } \\
\text { LIQUIDAÇÃO } \\
\text { EXTRAJUDICIAL }\end{array}$ & $\begin{array}{l}\text { AGRAVO EM } \\
\text { RECURSO } \\
\text { ESPECIAL }\end{array}$ & STJ & $\begin{array}{l}\text { Decisão } \\
\text { transitada em } \\
\text { julgado }\end{array}$ & $\begin{array}{l}\text { Banco } \\
\text { Nacional }\end{array}$ & $\begin{array}{l}\text { Indenização. Aquisição de Ações do Banco } \\
\text { Nacional }\end{array}$ \\
\hline 9 & $\begin{array}{l}\text { AREsp no } \\
98643 / \mathrm{SP} \\
(2011 / 019829 \\
2-8)\end{array}$ & $\begin{array}{l}\frac{\text { AGRAVANTE }}{\text { KPMG }} \\
\frac{\text { AUDITORES }}{\text { INDEPENDENTES }}\end{array}$ & $\begin{array}{l}\text { AGRAVO EM } \\
\text { RECURSO } \\
\text { ESPECIAL }\end{array}$ & STJ & $\begin{array}{l}\text { Remetidos os } \\
\text { autos (em } \\
\text { grau de } \\
\text { recurso) para } \\
\text { STF. }\end{array}$ & $\begin{array}{l}\text { Banco } \\
\text { Nacional }\end{array}$ & $\begin{array}{l}\text { Ação indenizatória de danos materiais e lucros } \\
\text { cessantes decorrentes de investimento feito pelo } \\
\text { autor em ações do Banco Nacional. }\end{array}$ \\
\hline
\end{tabular}




\begin{tabular}{|c|c|c|c|c|c|c|c|}
\hline & Processo & Partes & Tipo ação & $\begin{array}{c}\text { Vara/ } \\
\text { Tribunal }\end{array}$ & Status & Companhia & Assunto/ Objeto \\
\hline 10 & $\begin{array}{l}\text { REsp n }^{\circ} \\
1283737 \text { / } \\
\text { DF(2011/022 } \\
3035-6)\end{array}$ & $\begin{array}{l}\text { RECORRENTE: } \\
\text { MINISTÉRIO } \\
\text { PÚBLICO FEDERAL } \\
\text { RECORRIDO: } \\
\text { KPMG AUDITORES } \\
\text { INDEPENDENTES }\end{array}$ & $\begin{array}{l}\text { RECURSO } \\
\text { ESPECIAL }\end{array}$ & STJ & $\begin{array}{l}\text { Remetidos os } \\
\text { Autos (em } \\
\text { grau de } \\
\text { recurso) para } \\
\text { SUPREMO } \\
\text { TRIBUNAL } \\
\text { FEDERAL }\end{array}$ & $\begin{array}{l}\text { Banco } \\
\text { Nacional }\end{array}$ & $\begin{array}{l}\text { Ministério Público Federal - MPF ajuizou ação } \\
\text { civil pública em face de Banco Nacional S.A. e } \\
\text { KPMG Auditores Independentes, visando ao } \\
\text { ressarcimento dos prejuízos sofridos pelos } \\
\text { acionistas da instituição financeira, em processo } \\
\text { de liquidação extrajudicial, ante a alegada } \\
\text { existência de fraude em decorrência da conduta } \\
\text { irregular dos réus. Aduz que o Banco Nacional } \\
\text { omitiu e falseou informações, impossibilitando } \\
\text { aos seus acionistas de conhecerem a real } \\
\text { situação da instituição financeira, e a ré KPMG } \\
\text { não atuou com a diligência esperada das } \\
\text { empresas de auditoria externa, atestando } \\
\text { balanços irreais, ensejando prejuízo aos } \\
\text { acionistas, diante da falsa impressão de regular } \\
\text { operação do Banco no Sistema Financeiro } \\
\text { Nacional (fls. 33-71). }\end{array}$ \\
\hline 11 & $\begin{array}{l}\text { AREsp n } \\
88568 / \\
\text { SP(2011/0197 } \\
588-5)\end{array}$ & $\begin{array}{l}\text { AGRAVANTE: } \\
\text { KPMG AUDITORES } \\
\text { INDEPENDENTES } \\
\text { AGRAVADO: } \\
\text { ANTÔNIO } \\
\text { AUGUSTO DE } \\
\text { BARROS } \\
\text { PENTEADO }\end{array}$ & $\begin{array}{l}\text { AGRAVO EM } \\
\text { RECURSO } \\
\text { ESPECIAL }\end{array}$ & STJ & $\begin{array}{l}\text { 02/07/2015 } \\
\text { CONCLUSO } \\
\text { S PARA } \\
\text { JULGAMEN } \\
\text { TO AO(À) } \\
\text { MINISTRO( } \\
\text { A) } \\
\text { ANTONIO } \\
\text { CARLOS } \\
\text { FERREIRA } \\
\text { (RELATOR) } \\
\text { COM } \\
\text { AGRAVO } \\
\text { REGIMENT } \\
\text { AL E } \\
\text { IMPUGNAÇ } \\
\tilde{\text { ÃO }}\end{array}$ & $\begin{array}{l}\text { Banco } \\
\text { Nacional }\end{array}$ & $\begin{array}{l}\text { RESPONSABILIDADE CIVIL - Indenização - } \\
\text { Compra e venda de ações - Aquisição supondo o } \\
\text { autor o extinto Banco Nacional se encontrasse } \\
\text { com boa saúde financeira - Pareceres da ré que } \\
\text { sistematicamente apontavam nesse sentido - A } \\
\text { entidade bancária, entretanto, na prática } \\
\text { insolvente, mercê de criminosos estratagemas } \\
\text { maquiando sua contabilidade, transformando } \\
\text { prejuízos em lucros - Auditoria independente há } \\
\text { mais de vinte anos a ali operar, que deveria ter } \\
\text { constatado as gritantes irregularidades. }\end{array}$ \\
\hline
\end{tabular}




\section{Apêndice J - EMAIL DE TRANSCRIÇÃO DA ENTREVISTA}

Assunto: Transcrição da Entrevista e Termo de Consentimento

Prezado Xxxxxx,

Segue anexa a transcrição da entrevista para análise e, se necessária, edição, bem como o Termo de Consentimento Livre e Esclarecido (TCLE). Peço, por gentileza, que confirme que está "de acordo" (i) com o TCLE, (ii) com a validação da transcrição e (iii) com a autorização para divulgação do seu nome.

Importante ressaltar que para o propósito desta pesquisa tomei a liberdade de não transcrever $100 \%$ da entrevista, especialmente com relação a assuntos que embora interessantes escaparam ao foco da análise do trabalho em questão. Adicionalmente, durante sua revisão, peço especial atenção aos nomes de pessoas citadas durante a conversa.

A fim de oferecer maior comodidade ao entrevistado se, passados 20 (vinte) dias da data de envio desse e-mail não houver qualquer manifestação contrária em relação ao material editado, considerarei a concordância com (i) o TCLE, (ii) a validação da transcrição e (ii) a autorização de divulgação do seu nome.

Agradecemos mais uma vez pela sua imprescindível e valiosa participação no processo de nossa pesquisa e nos colocamos, mais uma vez, à disposição para quaisquer esclarecimentos necessários.

\section{Cordialmente,}

Gisele Sterzeck

Doutoranda em Controladoria e Contabilidade - PPGCC/FEA/USP

gisterzeck@usp.br<mailto:gisterzeck@usp.br>

Prof. Dr. Luiz Nelson Guedes de Carvalho

Professor Sênior PPGCC/FEA/USP

lnelson@usp.br<mailto:Inelson@usp.br> 


\section{Apêndice K - TERMO DE CONSENTIMENTO LIVRE E ESCLARECIDO}

Título da Pesquisa: Audit Expectation Gap (AEG) e o impacto nos litígios das firmas de auditoria

Pesquisador responsável: Gisele Sterzeck

Orientador: Prof. Dr. Luiz Nelson Guedes de Carvalho

Você está sendo convidado a participar voluntariamente da pesquisa Audit Expectation Gap (AEG) e o impacto nos litígios das firmas de auditoria, relativa ao projeto de tese sob a responsabilidade de GISELE STERZECK, discente do Programa de Pós-Graduação em Contabilidade e Controladoria da FEA/USP (PPGCC/FEA/USP).

Nessa pesquisa estamos buscando suas percepções e melhores esclarecimentos com relação às peculiaridades dos julgamentos no âmbito da CVM, uma vez que esses representam a maior quantidade de processos analisados, bem como apresentam fundamentações mais robustas na justificativa de seus votos.

Sua participação se dará por meio de entrevista semiestruturada, realizada por skype ou por telefone, nos dias e horários de sua conveniência. Estima-se cerca de 30 minutos de entrevista, a qual será gravada e transcrita.

Os riscos associados à sua participação neste estudo estão ligados a um possível desconforto com as perguntas e com a transcrição da entrevista não refletir exatamente seu pensamento. Para mitigá-los, a transcrição da entrevista será feita por empresa especializada em degravação e, assim, você receberá o arquivo do texto de sua entrevista, para avaliação e revisão se necessária. O sigilo e o conteúdo serão preservados, sob a responsabilidade da pesquisadora, a fim de garantir sua privacidade.

Após a defesa da tese, os áudios das entrevistas serão destruídos, e você será identificado no texto apenas mediante sua autorização. Os resultados da pesquisa serão publicados na tese e em outros trabalhos acadêmicos decorrentes dela. Você não tem nenhum custo ou ganho financeiro por participar da pesquisa.

Quanto aos benefícios do estudo, espera-se uma melhor compreensão do AEG no ambiente brasileiro, além das contribuições para pesquisas sobre auditoria e regulação do mercado de capitais.

Sua participação é voluntária, e você é livre para se recusar a participar, recusar seu consentimento ou interromper a participação a qualquer momento, sem que isso lhe traga qualquer penalidade.

Cordialmente,

Gisele Sterzeck

Doutoranda em Controladoria e Contabilidade - PPGCC/FEA/USP

gisterzeck@usp.br

Prof. Dr. Luiz Nelson Guedes de Carvalho

Professor Sênior PPGCC/FEA/USP

lnelson@usp.br 